\title{
axty
}

BOLANY OF' TO-DAY

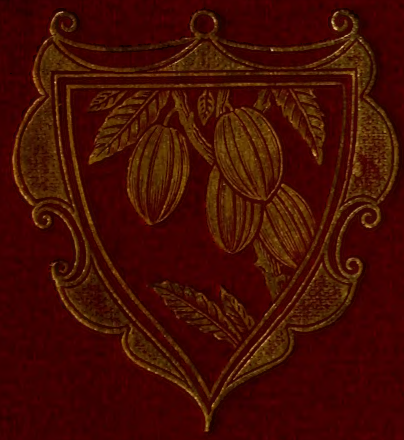

D

G. F. SCOTT ELLIOT 


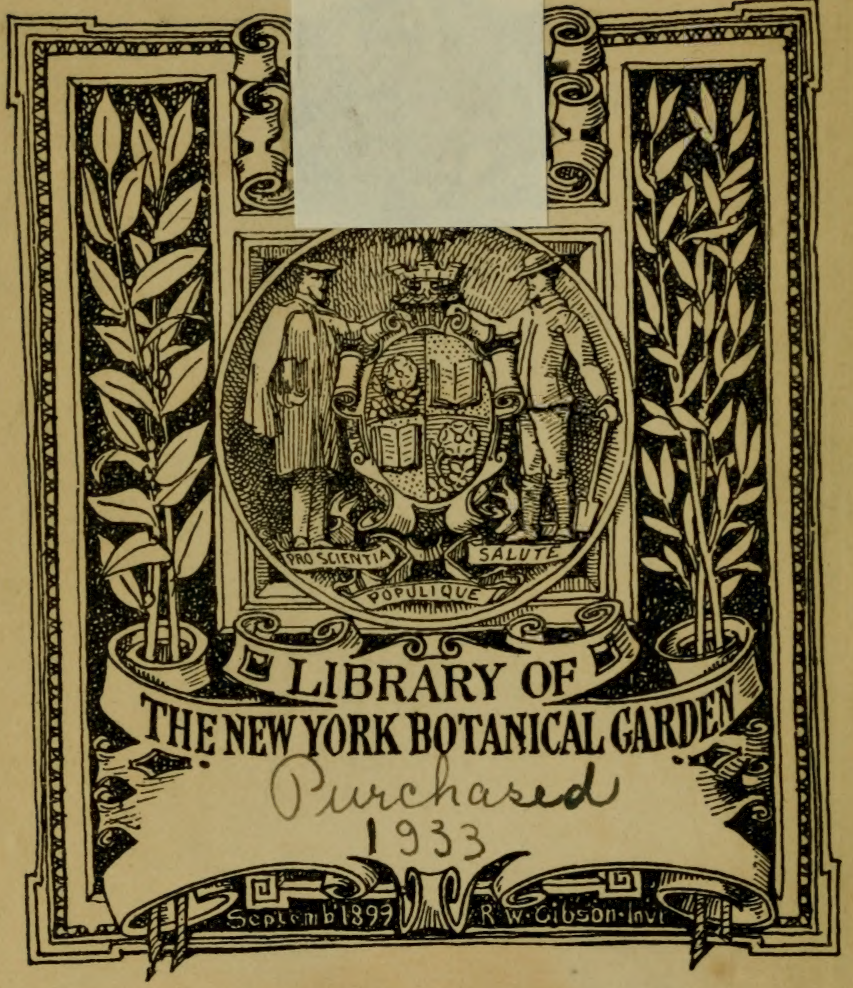


H.Menslow

$09 \cdot 10.25$ 



\section{BOTANY OF TO-DAY}






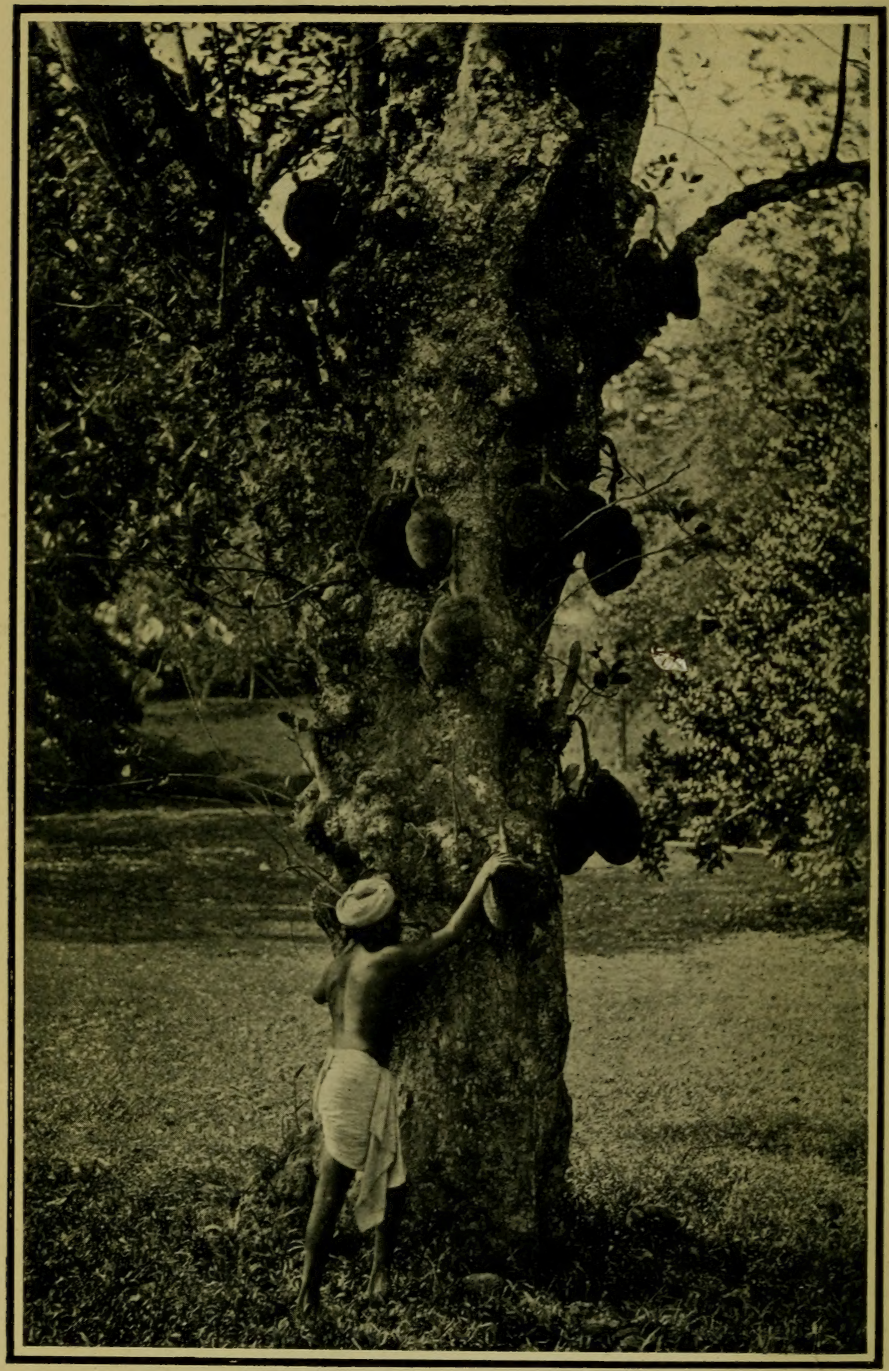

Photographed by]

[Skeen \&. Co., Ceylon

Tre Jack Fruit Tree 


\section{BOTANY OF TO-DAY}

A POPULAR ACCOUNT

OF RECENT NOTABLE DISCOVERIES

By

G. F. SCOTT ELLIOT

M.A., B.Sc., F.R.G.S., E्c.

Author of "The Romance of Plant Life,"

"The Romance of Early British Life," "A Naturalist in Mid-Africa," Ec. छc.

With Twenty-seven Illustrations

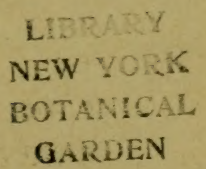

PHILADELPHIA

J. B. LIPPINCOTT COMPANY

LONDON : SEELEY \& CO. Limited rgo9 
QR 150

- .E39 


\section{PREFACE}

THE general idea of this book, like that of others in the same series, such as "Electricity of To-day," is to interest the reader in some at least of the many discoveries which have been achieved in our own times.

It is especially open air botany, the story of the conquest of the world by green vegetation, that has interested me. This naturally leads to a consideration of the exquisite contrivances by which a plant suits itself to its position in the world. It is not in the least like a dead leaf blown hither and thither by every puff of wind, for it is a living creature able to respond to its friends and fittingly to answer its enemies. Plants do look after themselves in the eternal struggle for existence.

The study of plant life reveals a strange mingling of benevolent co-operation with the most ruthless business competition which makes it always full of interest.

The process of selecting what should be omitted has been both difficult and delicate. Few people can have any just conception of the amount of printed matter in which the botany of to-day is contained.

But one may roughly estimate the yearly output of the botanical world by an examination of that invaluable work, Just's Botanische Jahres Berichte. This annual publication attempts to notice every important book, article and paper which has been published in one particular year. It is not quite complete, for in spite of the 


\section{Preface}

skill, carefulness and strenuous labour of the subeditors, occasional papers do escape them.

The notices are almost invariably very short; often only the mere title of an article is given or a very brief abstract.

Yet in spite of all this condensation and succinctness of treatment, the book consists, for the year 1905 , of three stout volumes with in all 2703 pages and weighing $12 ! \mathrm{lbs}$. (including a necessarily stout binding). The number of books, articles and papers which have been classified and noted for this year is very great, being no less than 12,872 .

The actual printing required for all these botanical works is difficult to estimate. Some may be books of 500 pages and others brief articles of five pages only, but on the very moderate estimate of twenty pages per notice, we obtain, for 1905 alone, the magnificent total of 257,440 , or say over a quarter of a million, printed patges, often of a difficult and technical character and written in perhaps eight or nine different languages. That gives one some idea of the enormity of the real botany of to-day and of the unmitigated inclustry of botanists all over the world.

I have been obliged to leave out much recent work on cell theory, on the fertilisation and development of the Cryptogams and on fossil plants. It is unfortunate that so much of English botanical work belongs to one or other of these abstruse branches, which really require for their enjoyment a long and arduous apprenticeship.

An attempt has been made to divest the botany of to-day of all those cumbersome technical terms in which too many specialists are inclined to bury their researches.

If a fact or theory in science is of any importance, vi 


\section{Preface}

it can generally be expressed in perfectly plain and simple language. Doctrines that have to hide themselves in the decent obscurity of bad Latin and suspicious Greek often seem neither at all novel nor particularly interesting when translated into the simple Anglo-Saxon.

But the process of translation is both dangerous and difficult. It is not only because the subjects often resemble the great text in Galatians in which twentynine distinct and different interpretations led to the most deplorable results, but it is really impossible to be quite impartial.

That would produce a cold and inhuman treatment which would certainly interest nobody. I have often had to adopt one theory out of many clamouring competitors. It is in the reader's interest that I have done so, not because I was unaware of the danger of errors and omissions.

I must apologise also to many authors for much that should and would have been inserted had I only known of its existence in time. An extraordinary number of books of the first importance appeared in the interval between printing and publication. The English edition of Warming's "Ecology" and Seward's "Darwin and Modern Thought" were not seen by me until it was too late to make any alteration.

In spite of what is euphoniously called the "literature" of botany, the labourers in the great World's Garden are still few and widely scattered. There is still opportunity for every kind of helper, and none can be safe in neglecting the most interesting of all the sciences.

G. F. SCOTT ELLIOT.

June 23rd, 1909. 



\section{CONTENTS}

\section{CHAPTER I \\ GENERAL}

What is protoplasm?-Aim of the Plant world-Glacial clay-Fresh lavas-Eruption of Krakatao-Succession of Floras-Tropical jungle as the most complex association-Foliage surfaces-British woods-Co-operation in woodlands-Wood anemone-Co-operation amongst its cells-Struggle for life . . . . . .

\section{CHAPTER II \\ SEAWEEDS AND LEAF-GREEN}

Leaf-green or chlorophyll-Its method of working-Green, brown, and red seaweeds-Colours and their importance-Changes in colour-Hot springs-Resistances to heat and cold-Arctic and Antarctic seaweeds-Macrocystis-Sargasso Sea-Floating marine organisms-Trades' dust-Diatoms-Labrador deposits of diatoms -Phosphorescence at sea-Alcohol and seaweeds-DesmidsParasites

\section{CHAPTER III}

\section{THE FIRST LAND PLANTS}

Land algae-Nostoc of gravel-Destruction of nitrogenous matter by fires and explosives-Nostoc and its special bacterial assistantNitrogen bacillus-Pliny on beans-Green manures-Tubercles of leguminosæ-Nitro-culture-Nitrogen and nitro-bacterine-Professor Bottomley's experiments and the results-Soil, constitution and air contents-Rich population in hollows, \&c.-Bacterial activity-Fungi in soil-Circulation of air-Heavy rain-FrostEffect of decimating bacilli-Roman bacteria .

\section{CHAPTER IV}

\section{BACTERIA}

Germs ubiquitous-Colonies of bacteria-Toxins and antitoxinsDefence of animal bodies-Phagocytes-Opsonins-Pasteur and hydrophobia-Vaccination-Imprisoned bacteria-Phosphorescent forms-Lamps of living germs-Spontaneous combustion-Bacterial colours-Rapidity of development . . . . . . .

\section{CHAPTER V}

\section{ROCK LICHENS}

The Trentepohlia forest-Exposure of lichens-Variety of colours-Dust -Destruction of rocks by lichens-Rhizocarpon in chalk-Quartz rock corrosion-Weathering-Slow growth of lichens-7ripe de rocke and reindeer moss. 


\section{Contents}

\section{CHAPTER VI \\ MOSSES AND PEAT}

PAGE

Theory of a moss-Rain absorbed-Protection afforded by moss cushions - Soil formation-Cannibal moss fronds - Fog of pasture Sphagnum-Formation of a peat moss-Antiseptic propertiesBogslides of a destructive character-Surface-dried mossesEstablishment of heather-Scotch fir seedlings-Cottongrass swamps - Reclamation of peat in Scotland, Switzerland-Cranberry culture -Peat products-Electrical works run by peat fuel

\section{CHAPTER VII \\ THE FERN ALLIANCE}

The Perie bush-Fern glades and Tree-fern forests-Coal-measure forests -Insects and animal life-Formation of coal in estuaries-Petroleum -Ingenious discoveries in coal fossils-Climate of the coal measures -Development of seed plants-Origin of a land flora-Seed plants in the coal measures-Distribution by fish-Jurassic flora- Bracken in Scotland-Its use as food.

\section{CHAPTER VIII}

\section{ALPINE AND ARCTIC FLORAS}

The summit of a British hill-Open foras-Competition for root-holdSphagnum $\approx$. blacherry $\approx$. cottongrass $v$. grassheaths-Tundra of Arctics-Frozen willows-Loss of water-Dry cold of Tibet and the Andes-Dwarfing of Alpines-Plants at 19,000 feet-Dwarf Juniper distribution and growth-Arctic and Alpine weeds-Alpine gardens-Rich flower colours-Ancient circumpolar flowers-Ballian alpines-Luzula in history . . . . . . .

\section{CHAP'TER IX}

\section{THE ANTARCTIC}

Algre, lichen and mosses at both poles-South America and New Zealand-Azorella in the Andes-Bullet-proof plant-Continent ends-Seed distribution-Albatross and Gentian-Wind-blown fruits-Connection of Grahamland and Patagonia-Effects on circulation of air and water-Common plants of Fuegia and New Zealand-Antarctic beechwood-Snares Island

\section{CHAPTER X}

\section{FLOWERS}

Thais and the rose of Jericho-What is a flower ?-Origin of sepals and petals-Work in a flower petal-Yellow flowers-Colour proportions-Genealogy of colours-Sunlight-Egyptian flowers-Cleistogamy-Bougainvillea and Bluebeard salvia-A tropical orchidColour v. Scent-Moths and painted flowers-Cycadofilix and Mayfly to orchid and bee-Insects and birds appearing with spring flowers-Insect visits and specialisation of flowers-Evening moths and campion-Shepherds' clocks-Opening of flowers-November flowers-Honey-Spurs-IVax-Ray florets-Erigeron-Stamens and nourishment-Bee and Spider orchid-Geranium stalksSelection 


\section{Contents}

\section{CHAPTER XI}

RECONQUEST OF THE WATER

Marsh plants and oxygen-Aerated tissues-Florida hyacinth-Phragmites-Pondweed leaf-Flowering of Elodea-Waterfowl and seeds-Trapella-Colonising of water by plants-Reed thicketsMarsh plants and seeds-IVaterlily zone-Abysms-Deepwater algæ-Hay meadows-Sudd of Nile-Ganges and AmazonsHylæa-Pampean sea-Submerged worlds of loch-Water lobelia association-Bankfoot colonisers-Cladophora in rivers-Apodya -Polluted water

\section{CHAPTER XII}

\section{SENSE-LIFE AND SENSIBILITY}

Anthropomorphism-Protoplasmic threads-Nanna and its criticsBreadfruit and Infusorian-Emotional distribution-Maeterlinck's laurel-Sunlight sensitiveness-Lenslike cells-Photographs by plant-cells - Hrmanthus - Gravity on Solomon's seal-Statolith theory - Tendrils - Barberry stamens - Heckel's operation Chemical sensitiveness-Bacilli and taste-Sundew and nepenthes --Massacre of butterflies

\section{CHAPTER XIII}

\section{THE INDIVIDUAL PLANT}

Sacrifice of old leaves-Self-surgery in leaves-Resin in an emergency-Regeneration-Beheading of roots-Fern growing-pointsTorenia leaves-Germ plasma-Ceropegia internodes-Competition within the body of a single plant . . . .

\section{CHAPTER XIV}

\section{SEASIDES AND STRAND PLANTS}

Circulation of water-Estuarine mud-Zostera meadows-Submerged pollination-Salicornia colonisation-Salt water and self-protection of Salicornia-The Camargue-Armeria mudflats-VaucheriaRushes and littoral meadow-Marine reed-thickets-SpartinaShingle beds-Sandflora-Sanddunes, formation and colonisation -Psamma-Chilian sanddunes-Landes of France-The dismal swamp-Spanish shores

\section{CHAPTER XV}

\section{DESERTS}

Winds and desert-Drying up of the world-Characters of desert plants-Ephemerals-Karoo-Plants like stones-Effect of rain-Cactus and Euphorbias-Shrinking of Cereus-Spines of Succulents - Grey hairs-Thorns and grazing animals-Cockspur thornGum-tragacanth-Thorny plants in moist climates-Iolly-Waita-bit Acacia-Distribution of acacia-Colonisation of desertsWelwitschia 


\section{Contents}

\section{CHAPTER XVI}

SUNSHINE, RAIN, AND WIND

Curious habitats of plants-The Darnel Fungus-Oak leaves and climate-Shapes of leaves and harmony-Waterfall plantsStatistical researches-Changes during growth of a wood-Limestone plants-Sunshine effects-Bracken in various situations-The patanas of Ceylon-Railway lines in Sweden-Reddening of plants -Bocconia stamens-Mode in ray florets-Rain leaves-Wind and leaves-Mechanical tissue and strains-Dust-Organic materialsRain-catching arrangements

\section{CHAPTER XVII}

\section{VEGETABLE AND ANIMAL}

Forests and man-Nettles - Loranthus in Australia-Mimicry in carboniferous period-Grasshopper and grass stems-Worms-Open floras and change by animals in Tundra, Patagonia, and HeathermoorsPoisonous Australian plants-Equisetums-Fungi of animal manure - Spruce gall insect-Aphid and its enemies-Nepenthes bicalcarata and its ants-Sunbirds-Elephants and Rafflesia-Ants and seeds

\section{CHAPTER XVIII}

\section{ANTS AND MITES}

Mite caverns in leaves-Inheritance of mite injuries-Spruce and ant plants-Stipule thorns and ants-Galleries in ferns-Nectaries on leaves-Leaf-cutting and fungus-cultivating ants-Ant gardens in the Amazons

\section{CHAPTER XIX}

\section{ELECTRICITY-RADIUM, N- AND X-RAYS}

Electric potential of air-Currents of electricity in plants-Reactions on stimulation-Increased assimilation-Roots and electric currentsNollet's, Bertholet's, and Speschnew systems-Thwaite's experiments-Electrocution of plants-Damage to trees and bacteriaLilac in electric light-Röntgen and radium rays-Dr. Russell's photographs $-\mathrm{N}$-rays

\section{CHAPTER XX}

\section{ORIGIN OF OUR BRITISH FLORA}

Flora of France before the Ice Age-Invasion of Northern IceSeparation of Alpine districts-Cardamine-Glacial boulder-clay -Climate of Ice Age-Dryas, birch, Scotch pine and oak florasSuccession of and upper limits of these associations-Botanical survey maps-Reid's and Lewis' researches-Peatmoss investigations-Climatic changes-Hazel in Sweden-Preglacial English plants-Geikie's Ice Ages-Tacitus and historical forests-Age of destruction-Weeds-Beech invasion-Cornish heath and Spanish plants-Irish Americans-Cinnamons 


\section{Contents}

\section{CHAPTER XXI}

\section{CONIFERS}

Werchojansk-Polar coniferous forests-Frozen soil-Northern forests-

Scotch pine-British Columbian forests-Larch in Europe-Larch disease-Sequoia of California-Monkey puzzle forests-Primzval forest in Bohemia-Highland woods-Woodfloor plants-Area of forest in Britain-Royal Commission-Forestry prospects-Labour -Finest Scotch conifers

\section{CHAPTER XXII}

\section{ARABLE LAND}

England before I789-Nomadic agriculture-King Alfred-Irish system - Braunton Great Field-Commons and Enclosures-Preparation of the land-Origin of weeds-Rate of travel-Weeds reclaiming clay-Vicia orobus in Germany-Times of flowering-Underground runners-Thistles, electrocution and spraying-Numbers of weeds -Production of Britain per acre-Food-supply in war . . .

\section{CHAPTER XXIII}

\section{GRASS}

Bamboos-Australian grasses-Rice and oats-Shooting of grassTussocks--Steppe grasses-Flowering and colours-Mechanical system-Hygroscopic awns and sheep-killing-Prairies and firesEffect of fires on trees-Wasteful system of agriculture-Grass pasture-Food value, vigour, method of growth, quickness of development, germination, preferences and price of the various grasses in pasture-Mr. R. H. Elliot . . . . . .

\section{CHAPTER XXIV}

\section{FOR'TUNATE ISLANDS}

Utopias-Cocoa-nut, banana and sago palm-Teneriffe and Von Humboldt-Zones of vegetation-Colonisation of lava flows and tree branches-Orchid seeds-Shorea fruits travelling-Bird migration -American seeds on the Hebrides-Navigator seeds of the Pacific - Currents and floating seeds-Development of new species in islands-Araucaria distribution-Giant lobelias

\section{CHAPTER XXV}

\section{PRACTICE OF PLANT-BREEDING}

Selection of best single seed-Sca island cotton crisis-Seven-leaved clover-Natural hybrids-Fern mongrels-Mr. Biffen's wheatsOrchid crosses-Luther Burbank-Prune-trees in a year and a half - Bonfires-Walnut hybrids-Spineless cacti-Larch experiments -Effect of altitude on seed-Sycamores and leaf fall-Varying conditions-Potatoes in icehouse-Degeneration of potatoes-Fife wheat 


\section{Contents}

\section{CHAPTER XXVI}

\section{THEORY OF PLANT-BREEDING}

Acquired characters-Desert plants-Little species of Lamarck-Supply and demand in the plant-American trotting-horse-Germ plasmas and Begonia-Mutation-CEnothera Lamarckiana-Double flowers - Fasciation-Physiological state-Mendel and his experiments -Presence and absence of colour-Miss Saunders' stocks-Hurst's tomatoes-Dominance-Pollen parent affecting colour-Iris with six stamens-Grafting and its effects

\section{CHAPTER XXVII}

\section{SCRUB}

Thorny acacias-Naqui-Gum-cistus-Scented labiates-GarigueWild-olive woods of Spain-Sheep in Spain-Moors and slavelabour-Nediterranean cultivation-Goats and other animalsBalearic islands-Gums and perfumes-Flower industry-Mosquitoes and basil-Ethereal oils and their importance-Cape Colony, Australian, Californian and Chilean scrub

\section{CHAPTER XXVIII}

\section{TROPICAL HORESTS}

Wet jungle of West Africa-Elephant grass-Leaf-stories in the jungle - Animal life-Insects-South Mexican forest-Rubber and its collection-Rubber plantations-Oil palms-Mosquito and malaria - Extending cultivation-Fires in Nigeria-Mangrove forestSeedlings of Rhizophora-Colonisation of mud

\section{CHAPTER XXIX}

\section{ON EVIL IN SMALL DOSES}

Origin of variations-Biometrical researches-l'ure lines-SugarbeetRoots and carbonic acid-Salt on plants-Mincral poisons-Alcohol and ether-Electricity-Heat and cold-Gladiolus bulbs and wounds-Fungus and insect attacks-Palm leaves falling-Enzymes - Miss Gibson and chrysanthemum fungus-Mr. Salmon's mildews and bromes-Rusts and mildews-Infection of sickly plantsBegonia and a cucumber fungus-Mycorhiza-Lichens-Insect visits-Animal injuries-Effect of man-Students of Nature . . 


\section{LIST OF ILLUSTRATIONS}

The Jack Fruit Tree . . . . . . Frontispiece Cutting Fruit from a Plantain Tree .. . . 22 Planting Tea Seedlings . . . . . . . 48 Tree. Fern Stent Section . . . . . . 60 Rattan Cane . . . . . . . . 60 Glacier Bay, Straits of Magellan . . . io2 YUCCA IN Bloon . . . . . . . IIO Liberian Coffee $. \quad . \quad . \quad . \quad . \quad . \quad$. 122 Land Formation in Ponds . . . . . I30 Alfalfa and Butterfly . . . . . . 150 Sanddunes at San Vicente, Chile . • . . 166 Plucking the Leaves of a Tea Plant . . . I 78 A Banyan Tree . . . . . . . . . 188 Stinging Hairs of the Nettle . . . . 196 Végetable Marrow, Stem Section . . . . 196 Plucking Cocoa Pods . . . . . . 208 Chestnut Woods in a Corsican Valley . . . 220 Tapping a Maple Tree . . . . . . . 238 Preparing Maple Sugar . . . . . . 248 Near Ajaccio, Corsica . . . . . . 252 The Giant Bamboo . . . . . . . 262 Cocoa-Nut Palms near Aguadilla . . . . 274 The Screw Pine . . . . . . . . 280 A Giant Cactus . . . . . . . 290 Vineyards in the Chanpagne District . . . 308 MAQUi in CoRsica . . . . . . : $3^{\mathrm{I} 2}$ Gathering the Cocoa Crop • • • . 324 



\section{LIRPARY}

MEIV YORK

EORANICAL

GAKDEN

\section{BOTANY OF TO-DAY}

\section{CHAPTER I}

GENERAL

THE Botany of to-day is a vast subject, and intricately connected with almost every art and craft that man has ever invented. It is also an infinitely varying and complexly developing science, dealing not merely with the discoveries of mankind but with life itself.

But what sort of life it is that vegetables possess, remains an insoluble mystery.

Under the microscope we can make out that all plants are made up of the minute compartments called cells, in which one finds a colourless, slimy, living matter "protoplasm" or "life slime." We have advanced considerably in our knowledge of the various methods by which we can stain or harden this protoplasm; we are beginning to suspect that the complexity of its atoms (if it has an atom) is almost beyond our comprehension; we know, crudely, what it will do when given mertain solutions, under various temperatures, under an oblectric shock and at various atmospheric pressures; -modern microscopes have also revealed an extraordinary -amount of unexplained detail in its apparent structure, But as to what it is, how it lives, dies and reproduces Itself, we are still in a state of hopeless ignorance. 


\section{General}

This minute speck of living slime defies our analysis, for it is alive; it does things of itself, and it certainly does them on purpose.

This point is far too frequently left out of sight in the botany of to-day.

We forget that we are dealing with we know not what; that all protoplasm is a living mystery of whose origin we are utterly ignorant, except that, so far as we know, it never forms, except as a descendant of other living material.

Organic substances have long ago been produced in chemical laboratories, but even there they are not accidental self-formed products, for they are made by the selection and skill of an intelligent being who is himself a product of live protoplasm cells.

In another chapter we shall have to notice some of those vague and curious speculations which deal with the soul life or sense life of vegetables. Does the live cell enjoy itself? Is it conscious of its desires and of its discomfort, say in cold weather or when introduced to some poisonous secretion?

But in this first chapter we are not to be entangled in such questions as these, nor shall we wander in those vague and devious speculations which have nevertheless a very distinct and definite interest.

We do not realise the immensity of the task that lay before the first vegetable cell. Here was the earth, utterly and entirely mineral, without the slightest trace or touch of organic matter, neither "soil" in the gardener's sense nor bacteria; the water was without micro-organisms, and the land was original rock, barren sand, or bare mud.

The author once had the opportunity of seeing on a large scale the extraordinary difference between good and what we may call "mineral" earth (which we use 


\section{General}

because there is no recognised translation of the German term "Urboden," which means land or soil which has never been touched or altered by plants).

In making a tunnel near Glasgow, a layer of almost liquid clay had been struck. On a field close by the ordinary surface soil had been removed from a few square yards and piled up in a long mound, and the whitish clay which had been buried deep in the earth since some time in the ice age was deposited on the vacant space.

After the work had been stopped, there was an extraordinary difference between the flowers on the mound of surface soil and those of the "mineral" clay. During two summers scarcely a plant succeeded in establishing itself on the clay, and those few that did manage to grow did so unhappily and seemed also to depend chiefly upon blown dust or accidental patches of good earth. On the mounds of surface soil the weeds and grasses were extremely luxuriant, and produced a rich and flourishing crop in a very short time.

A freshly cooled lava flow is perhaps the only modern representative of what was the condition of the whole world before plants had begun to colonise its surface. The manner in which such fresh lavas are gradually occupied by vegetation is extremely interesting, because this process gives us some hint as to how, in the very earliest of all geological periods, the plant-world may have set about its task.

The eruption of Krakatoa gave a splendid opportunity for such observations; an entirely clean sweep had been made of all living plants and animals: the soil was nothing but newly cooled lavas or volcanic ash.

Dr. Treub found that the first vegetation consisted of certain minute blue-green seaweeds. Next came a profusion of ferns, and at a later date especially such flower- 


\section{General}

ing plants as are usually found growing on the bark of trees.

Similar observations have been made on the Vesuvian lavas and on those of Greenland. On these lichens and blue-green seaweeds (or algr) make up the first vegetation. Mosses are mentioned as characteristic of a later stage, but ferns and lycopods are not apparently of much importance.

It was shown, however, that, after the moss or fern stage, lavas were at first covered by sparsely scattered plants adapted to very dry conditions, and that some years elapsed before shrubs and eventually trees could grow upon them.

Now it is generally admitted that the lowest and least specialised of all plants are the algæe or seaweeds, of which the bluish-green family are perhaps the lowest in the scale of development.

The bacteria and other fungi are usually supposed to be algæ which have lost their green colouring matter. Except in this respect, they are on the same very low level as the algre. Lichens are compound plants clue to the union of an alga and a fungus.

So the first colonisers of the lava were, as one would expect, algre and lichens.

We have no geological data to show whether mosses preceded the fern alliance in development, but they are surely a lower and less specialised group.

The flowering plants came upon the world's stage last, and are certainly the most complex of all. They form associations of many kinds of plants which both co-operate and compete with one another, and amongst these associations a wood is the highest, and a thicket of shrubs is more complex and better developed than an open scattered growth of small perennial plants. 


\section{General}

If, then, one were prepared to speculate on the original settlement of the earth by the plant world, one would expect the dry land to have been occupied by, first, Algæ, Fungi, and Lichens; 2. Mosses; 3. Ferns; 4. Flowering plants in an open flora such as one sees in a desert, in Tibet or in the Arctic Regions; 5. A close flora of small shrubs; and 6. Trees or a wood association.

At present the development of flowering plants has reached such a stage that they grow almost everywhere, and are adapted to all sorts of climates and conditions; and yet we find in the colonisation of these lavas, hints which seem to explain the old original process.*

Something of the same succession can be traced even now on mountain sides and in the Arctic Regions. For, as we shall see in another place, lichens occur on boulders or bare rock in far Northern latitudes, also on mountain ridges where not even mosses can manage to exist. An open or scattered flora of small half shrubby plants characterises both the highest Alpine and most arctic conditions. Heather moors extend farther up the mountain side and more to the north than trees; and even amongst trees, coniferæ, which are relatively older and less complex in structure than the deciduous trees, are often found as mountain and northern woods, when the lowlands are occupied by oak forest or other deciduous woods.

So that if one assumes that the plant world even to-day is proceeding with, but has not finished its task of occupying the far north and mountain summits, then we see in every case a higher and more advanced kind

* Tropical lavas show blue-green Algæ, Ferns, Rock plants, Shrubs, Jungle. Temperate lavas show Lichens, Mosses, Open Flora, Shrubs, Trees. Old walls show Lichens, Mosses, scattered Herbaceous plants. 


\section{General}

of vegetation pressing upon and replacing the lower association.

This way of considering the plants even in a country so well known as Great Britain makes many small points very much more interesting.

When a stone wall or a new bridge is built, one sees first lichens, then mosses, and occasionally ferns beginning to occupy the new territory.

It is new untrodden ground, and requires the old primeval form of attack.

But when ploughed land or the pared edges of a roadside are overgrown by weeds during the summer, the conditions are not exactly the same. The earth is rich soil full of dead vegetable matter, and probably full of bacteria and worms.

So one often finds grasses and various weeds springing up only a very short time after the earth is exposed. Even on rich soil of this kind, however, both alga and mosses are by no means unusual. In autumn the stones of a turnip-field are sometimes green with alga and occasional patches of moss may be found.

In the more advanced kinds of plant associations, such as, c.g. a well-grown tropical jungle, the amount of vegetation formed per square yard is extraordinary, indeed almost incredible. Almost every kind of plant life may be represented.

There are first the tallest trees whose leaves forms the uppermost "canopy" or foliage surface ; from their upper branches there usually hang down coiled, entwined and rope-like lianas, sometimes twining round the tree stems, more often hanging like festoons or wreaths from above. The foliage of these creepers forms a second leaf-surface or floor. Below these are the younger trees which have been arrested in their 


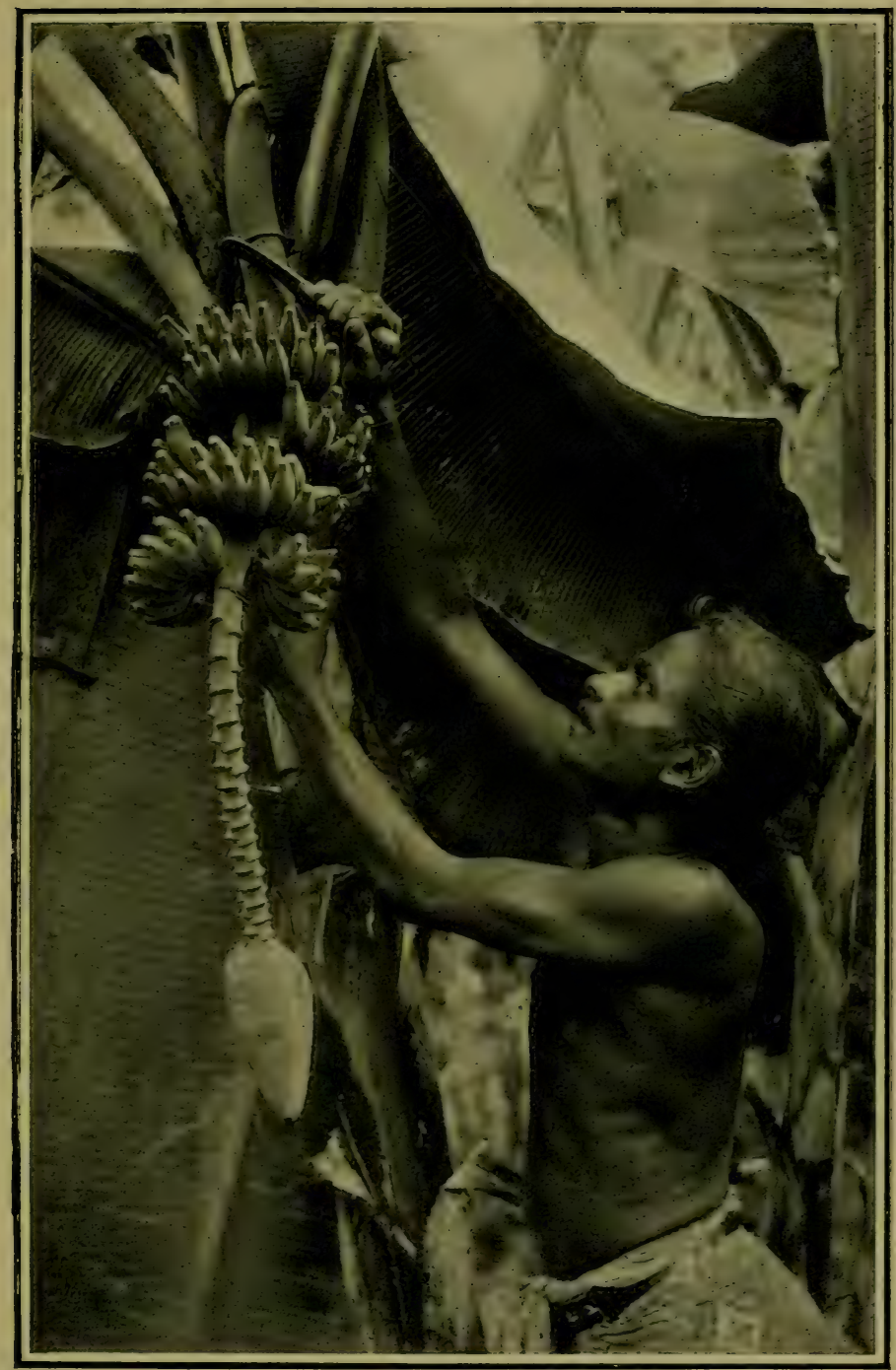

Pkolographed by]

[Skeen \& Co., Ceylon

A Native Cutting the Fruit from a Plantain Tree, or COMMON BANANA 



\section{General}

growth and patiently await the fall of some venerable forest giant which will give them the light and air which they earnestly desire.

On the ground there may be a fairly close carpet of bulbs or ferns, or herbaceous plants. So that even of the flowering kinds there are four more or less distinct "storeys" or surfaces of green leaves.

But in such a jungle as this there are not only flowers, but also ferns, mosses, liverworts, fungi, bacteria, and algæ. It is often the case that every branch or fallen trunk is entirely concealed by a lovely living cushion of branching feathery mosses mixed with delicate-stemmed liverworts. In amongst the moss one sees sometimes the flowers of an orchid, or more often the graceful rosettes of ferns.

The latter are common; sometimes as tree-ferns they form part of the arboreal vegetation, but more usually they are perched in the fork of some great branch or grow in rows along a horizontal one. There are of course many other kinds of "epiphytes" (epi upon phyte plant; this means growing upon another plant instead of on the ground).

Curious barred Bromeliads, many Orchids, Pipers, Peperomias and others are particularly partial to this sort of existence.

Nor are algæ at all rare, for many parasitic kinds grow upon the leaves of trees or on the soil under the foliage, or perhaps amongst the mosses on the branches which are rapidly decaying and crumbling away through the attack of many sorts of fungi and bacteria.

Such a jungle with four distinct and separate foliage layers or green leaf-surfaces, with its lianas, epiphytes, mosses and the like, is perhaps the culminating and highest effort of modern vegetation. The amount of 


\section{General}

working green material per square foot of sunlight is almost incalculable.

It enjoys, of course, maximum sunshine and ample moisture. When either of these factors is at all deficient, there is very much less complexity and far less exuberance of growth.

In our own woods and forests, the most favoured places seldom possess more than three green layers. There is (I) the tree foliage; (2) an undergrowth of male and lady fern, with wood flowers such as Hyacinth ; and (3) a carpeting of feathery mosses* (Hylocomium and Hypnum, sp.).

A very few years ago any scientific person, when let loose in such a botanical paradise as the tropical jungle of West Africa or Java, would do nothing but feverishly collect and dry any flowers that he saw. He would be so entirely occupied, so thoroughly happy in the extraordinary profusion of flowers unknown to him, and very likely new species, that he would probably fail to see the "wood" for the trees.

Even to-day and in Great Britain, there is much to be discovered about the way of life of a "wood" considered as a whole, and not as a catalogue of individual plants.

Such plants as Foxglove and Raspberry, which spring up in extraordinary profusion when a wood has been felled, may be compared to the seed leaves or cotyledons of a single plant. They are apt to vanish when the wood begins to reform itself. But they are of some use to it, for two or three years' growth of these forerunners cover the soil with rich layers of leaf mould and utilise all the sunshine that falls upon the surface during those years.

* Five leaf-surfaces are said to exist in many tropical jungles, but the author has seldom seen more than four. Often they are so jumbled up as to be quite indistinguishable. 


\section{General}

So also with the thorny thickets of sloe, blackthorn and hawthorn, through which the young trees have to force their way upwards to the light. One might compare them to the sticky bud scales of a horse-chestnut shoot which guard the young and green leaf rudiments from fungi and insect pests.

Such a thicket would keep out roe and red deer or cattle, and so give some chance for the quick growth of ashes and birches and the slower and more sturdy development of young oak trees.

So soon as the forest trees grow up and overshade the thorny rosaceous shrubs, these latter die away, but their life work is not wasted. Everything that they have made, every particle of carbonic acid or of nitrate used by them is returned to the soil, and is used again by the higher form of vegetation.

In this connection the higher plant is both the taller and also the more complex. An oak or beech is of much more importance to the world than a hawthorn.

Every green plant growing in such a wood, even the algæ which form the green stain upon the bark, the ferns, mosses, and undergrowth is of use. For its waste products are returned to the soil, and form part of the regular annual manuring of leaf mould.

The best authorities in forestry are careful to warn planters of the danger of taking a way from the forest even, for instance, the apparently useless ferns and bracken. If this is permitted the soil must be impoverished. The most pernicious of all customs is that of collecting the dead leaves and actually burning them, and yet this wanton waste of the richest manure is by no means unusual.

Just as, or even more, important is the part played in the growth of a wood by the fungi, bacteria, and various insects and other small animals.

Many of these are kept by the forest; there is a 


\section{General}

bewildering variety of horrible little creatures found in decaying wood, or under the bark of fallen branches. They break up the useless and dead wood and return it to the soil in the form of rich and valuable manure. The fungi and bacteria living in the soil and about the roots are also most useful, for it is by their help that the tree-roots obtain a rich and quick supply of nitrates and other salts.

So a wood is really an extremely puzzling and complicated co-operative society, in which there are numbers of quite distinct and different organisms, both animal and vegetable, engaged in a common task, and so far as we know entirely unthinking of anything except their own individual advantages.

Even in one single plant, say, for instance, a Wood Anemone, which is a regular woodland flower, one finds the same difficult questions so soon as one begins to realise its manner of life. Its fleshy stem is wholly below ground, and the plant is out of sight during most of the year. This fleshy, scarred, underground stem is full of starchy material, which means that many of its cells are starch store-rooms. The roots attached to it which explore the leaf mould are assisted by a curious fungus (mycorhiza) which is of use to them. Such fungi grow more rapidly than roots, and are probably specialists and experts in the task of obtaining nitrate and other salts. The cells of the root therefore are devoted to supplying the fungus with sugar and the stem with water and salts in solution.

The three leaflets raised above the spring vegetation by long stalks not only possess green cells which manufacture sugar from carbonic acid and water, but they also contain special cells to toughen and strengthen the leaf and others which convey the formed material down to the stem. 


\section{General}

The little protective scales of the flower bud are modified leaves. In the flower one finds many other cells besides those which form the important pollen of the stamen or the egg-cell of the young seed. There are, for instance, coloured cells, reddish or violet in the petals (botanically, sepals), which protect the delicate ferments at work in the supply of sugar to the seed; hair-cells which keep off undesirable insects. There are somewhere in the stalk of the flower sensitive cells which somehow or other contract and expand, so that the flower hangs its head in wet weather (when insects are benumbed) and becomes erect and opened out in sunshine or warmth when many insects are abroad.

As the stalk grows older and the seeds ripen, it becomes taller, keeping usually above the neighbouring vegetation. It is then tough and elastic, and very different in character from the young flower-stalk. This means a great change in the habit and character of the cells which form it.

So that in the "body" of the Wood Anemone, which is made up of these minute living cells, one finds the most varied duties apportioned to these latter. All contribute somehow to the general welfare of the Wood Anemone; that is, they form a co-operative association with a common end. Yet one can hardly believe that the root cells, e.g., are in the least aware even of the existence of the flower for which they work themselves to death.

It might be possible to show that some of them are competing eagerly with one another. The leaves are ruthlessly sacrificed as soon as they are past work, and the flower begins to form. Bud scales, petals, and stamens are at once thrown off so soon as they have fulfilled their functions. The whole flowering stalk is sacrificed as soon as the seed is scattered, and the fat, 


\section{General}

black, buried and scarred stem remains for some six months at least compact, well guarded, and awaiting the reviving influence of the spring.

So both in one plant such as the Anemone, as in a whole association like a wood, we find whole categories of cells or of species which are at work in a common employment of whose end and object they are surely utterly unaware. 


\section{CHAPTER II}

\section{SEAWEEDS AND LEAF-GREEN}

THE major planet Earth probably differs from all its companions in space in one special respect.

It is a "green" world, and this colour is no accidental ornament, but is the real fountain and origin of all the life that swarms upon its surface.

Not only the growth of plants, but all animal and human activities-the soaring of a hawk, logical reasoning, or any kind of mental or emotional strain -depend upon this peculiar green substance "chlorophyll."

One cannot exactly say that the world depends upon chlorophyll in the way that a motor is "run" by petrol, for this chlorophyll may not be used up in the process. It is a sort of chemical sensitiser which absorbs certain kinds of sunlight. That is, the energy of their vibrations is intercepted and turned to another form of work.

Our food, which is necessary for every strain of nerve or muscle, consists of animal and vegetable matter, and this last represents the life-work of chlorophyll or "leaf green."

We cannot give more than a very general idea of the way in which the chlorophyll works. The coolness and shade under a beech tree even in very hot weather is enough to show that the leaves have somehow intercepted most of the sunlight. To follow the process a little more closely, one must imagine a leaf with the 


\section{Seaweeds and Leaf-green}

sunlight falling on it and supplied with a continual stream of sap by its parent tree. Under a microscope one can see the small chlorophyll bodies, but the green material forms only an inconceivably thin coating over them. It may be one-10, oooth or even one- 25,000 th part of the thickness of a millimetre.* Supposing that the light falling on the leaf of a lime tree during one minute only is held up by this thin chlorophyll layer, then the heat that would be produced in it might amount to something like $6000^{\circ} \mathrm{C}$.

It is hardly likely that such temperatures are ever realised, for the absorbed energy is probably spent as rapidly as it is taken in. Water is being evaporated and requires about 8 per cent. of the absorbed energy. Another 3.3 per cent. is required for the chemical cookery at work by which in the end sugar and starch are produced in consequence of the splitting up and rearrangement of carbonic acid and water.

The details of the process are still very obscure or rather form the subject-matter of a violent controversy. Some authors hold that the green matter can produce carbohydrates outside the living cell, which would be very interesting if true. Under strong light it may be that chlorophyll is decomposed, and that one of the products is formaldehyde; from this last substance sugar might be formed without much chemical difficulty.

But at any rate sugar and other carbohydrates are formed in the leaves and subsequently worked up into proteids and other food material of the living protoplasm.

The process may be perhaps followed more clearly if one reflects upon what happens when sugar or

* That is, ${ }^{\circ} 000003937$ of an inch or less. Compare Timiriaseff, ${ }^{1}$ Usher and Priestley, ${ }^{2}$ Ewart. ${ }^{3}$ Hydroxyl and nascent Hydrogen are supposed by others to be first formed. 


\section{Seaweeds and Leaf-green}

cellulose is burnt up. Carbonic acid gas, steam (water), as well as light and heat reappear.

But for such a fire a supply of oxygen is essential. So when the sugar is formed in nature, which is the reverse process, we find radiant energy, carbonic acid and water being used up, but we also find that surplus oxygen is given off.

All green plants possess this power of forming new organic material out of inorganic carbonic acid and water, but there are certain interesting differences between them.

The first and lowliest group of plants, the seaweeds or algæ, are not all green.

It has long been noticed that on an ordinary rocky, gently sloping seashore where seaweeds flourish, there are green, brown, and red kinds.

Close to the level of high tide one finds bright, grassgreen enteromorphas and ulvas. The territory of the slimy wracks and tangles or kelp, which are mostly of an olive or reddish brown, lies between high and low water-mark.

At about the lowest level of the tide and below it to a considerable depth, one finds neither green nor brown algæ, but only those graceful and delicate red, pink, or purplish-red forms which are the ones usually selected for preserving on blotting-paper. At a certain depth one finds no living algæ of any kind.

No one could help speculating upon these colour changes, and to-day we are almost in sight of a complete explanation.

The deep blue colour of the ocean is connected with the fact that other colours in the sunlight, and especially those red-yellow rays, which are the most important for plant-life on land, are absorbed by comparatively shallow depths of sea-water. This point was ingeniously tested 


\section{Seaweeds and Leaf-green}

by Dr. Jönnson in Christiania harbour. ${ }^{4}$ He let down into the sea specially built glass boxes in which were certain living mosses. The constitution of the air in the chambers was exactly known, so that by testing the amount of carbonic acid and oxygen in the chamber after it had been left submerged for some time at different levels, it was possible to know what the mosses had been doing.

The results were very interesting, for it was found that the deeper the level at which the moss was placed the less carbonic acid was assimilated, and at a depth of sixty or seventy feet it was unable to do any work at all. This is just about the lower limit of algæ in Christiania harbour. The water had absorbed all the assimilation rays at this level.

If one could rest comfortably at the depths where the red algæ live, and look up towards the sky, the whole world would appear blue. By their red colour these algre are able to use the blue rays of light, which are suspected to have some injurious effect on the physiology of plants unless so shaded.

In the territory of Fucus and the other wracks and tangles the conditions are mixed. Some of the red rays are absorbed at high tide, whilst at low tide the full power of the sunlight beats down upon the chlorophyll, so that we find here a mixed condition. Mixed red and green do not make the Fucus brown, but the colouring matter will act as a protective mixture of some kind.

So it follows that these colours of the seaweeds, although pretty and ormamental, are by no means accidental, but of very real use to the plants concerned. ${ }^{5}$

Another step has been gained by Dr. Gaidukov's experiments with one of the blue-green algæ. This form (Oscillatoria sp.) shows great variations in its natural colour when found growing under different conditions. 


\section{Seaweeds and Leaf-green}

It was made to grow behind specially contrived screens of coloured glass, and the results were as follows :-

Behind red glass, that is, in red light, it became green.

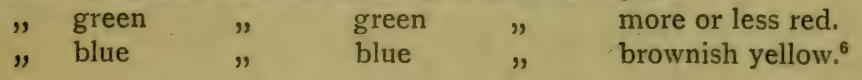

This shows that Oscillatoria is able to produce whatever colour suits itself best, which is a most important discovery. But how is it that the wave-lengths of one colour set up in Oscillatoria a substance which gives out the vibrations of the complementary shade?

This is, however, an instance of what we may call a "fitting reaction" directly produced by the conditions and useful to the plant. No one, not even Maeterlinck, would suppose that oscillatoria had studied optics and intentionally manufactured the green or red, but still the colour is produced.

Plant life must have commenced at some period in the history of the earth. There was a time when the world seems to have been nothing but gas and mist at a very high temperature. Even in such early geological times as that of our Coal Measures, many plants, and some of them very highly organised, were in full activity. Even then, some authors suppose that the whole ocean had an average surface temperature of $70^{\circ} \mathrm{F}$. $\left(21^{\circ} \mathrm{C}\right.$.), and that there was no cold water either in the Arctic or Antarctic Seas.?

Many algæ would thrive in hot water of this temperature. Indeed, from what we know of the endurance of living protoplasm, it would be very difficult to say what degree of heat would necessarily destroy all vegetable life.

Even to-day algæ are said to flourish and grow well in certain very hot springs. The water in those at Karlsbad is at $70^{\circ} \mathrm{C}$., and in the baths at Las Trincheras, Venezuela, $80^{\circ} \mathrm{C} .^{8}$ Some doubt has been expressed as 


\section{Seaweeds and Leaf-green}

to the fact of algæ flourishing in such temperatures as these, but at any rate they do live at $52^{\circ} \mathrm{C}$. and quite vigorously. ${ }^{9}$

As seeds and spores, vegetable protoplasm is able to support far higher temperatures even than $70^{\circ} \mathrm{C}$. Mosses have survived temperatures of $80^{\circ}$ and $90^{\circ} \mathrm{C} .0^{10}$ Bacilli have been known to grow at $60^{\circ}$ to $70^{\circ} \mathrm{C} .11$ Seeds of certain flowering plants were not killed by exposure to enormous temperatures such as $90^{\circ}$ or $120^{\circ} \mathrm{C} .,^{12}$ and a yeast spore revived after $130^{\circ} \mathrm{C} .{ }^{13}$

Perhaps the endurance of great cold is even more remarkable.

Those very algæe which thrive at $52^{\circ} \mathrm{C}$. can withstand a cold of $-12^{\circ} \mathrm{C}$. for four hours, and various spores of seaweed were not killed by $-20^{\circ}$ to $-30^{\circ} \mathrm{C} .^{14}$ Drs. Macfadyen and Rowland found that the spores of some bacteria began to grow again after they had been chilled for ten hours at a temperature of $-252^{\circ} \mathrm{C} .15$ Not only so, but the seeds of several vegetables were kept for 130 hours at temperatures of $-185^{\circ}$ to $-192^{\circ} \mathrm{C}$. and were not much the worse, germinating quite satisfactorily after this awful and unimaginable cold ! 16

It is very hard to understand such facts as these. How is it possible that living protoplasm can endure such horrible extremes of temperature which indeed can scarcely ever be produced naturally? No doubt the protoplasm must be dry and perhaps temporarily lifeless during the process, but then how is it that its delicate complex mechanism is in full working order as soon as the conditions improve?

These facts are, however, quite sufficient to assure us that low forms of algæ might have been in existence at a very early stage in the earth's history and long before there were snow caps at the North and South Poles.

It also explains why we find algæe luxuriantly flourish- 


\section{Seaweeds and Leaf-green}

ing at latitudes of $80^{\circ}$ North where the water is never much above the freezing point. At this latitude Kjellman discovered no less than twenty-seven species, and most of them in fruit. ${ }^{17}$ Close upon three hundred species of seaweeds are to be found in the Arctic and Antarctic Oceans.

So that if the reader is to picture to himself the seaweed life of the world, he must first clothe all the rocky shores of all the continents and islands with rich submarine tangle-forests extending far up into the Arctic and Antarctic zone.

Indeed the growth of these seaweeds seems perhaps most luxuriant in the colder seas. As one approaches the Straits of Magellan, the sea seems to be provided with an inexhaustible supply of the great brown alga (Macrocystis pyrifera). Patches of it may be passed every few minutes, sometimes being researched by penguins or other birds, or as long trails bobbing up and down in a curious way in the slow heaving rollers. Some have suggested that this "kelp" may have the honour of explaining the sea serpent, for a long trail of it might be mistaken by an imaginative apprentice for that shy and retiring creature.

Macrocystis is said by one authority to be sometimes 300 feet in length, which would surely be long enough for any sea serpent! 18

When one arrives at the Straits and passes through to the Pacific Coast, the islands are very often surrounded by a curious border, roo feet wide, of this extraordinary plant, which is surely the longest if not the tallest on the earth.

Near Capetown, there are giant algæ allied to our laminarias which have stems as thick as a man's waist. Even in the Faroes, the thickets of these brown algæ and especially laminaria are said to be about six feet high and extraordinarily luxuriant. 


\section{Seaweeds and Leaf-green}

The great Sargasso Sea is supposed by some authors to occupy an area as large as Europe, and to be formed entirely of algal fragments torn by storms from the coast-line. But the common Sargasso weed has not yet been discovered anywhere on the shore-line of America. It is well able to float, for it has hundreds of little buoys about the size of a pea along its fronds. Such seaweeds are undoubtedly dangerous to navigation, for if twined round the screws or paddle-wheels they might stop the engines suddenly and cause an explosion; but the lurid tales about its awful inhabitants and ancient derelicts have not been scientifically confirmed.

Great as must be the amount of shore seaweeds, they are by no means the most important of the order. Algre occur also in fresh-water lakes and in all kinds of pools, rivers, streams, and rivulets. The bottom, if not more than 30 feet deep, and the sides of all such freshwater surfaces, are usually densely covered with them.

But the most important in the world of all algæ are those which are not attached to the shore at all, but which float free in the water and are carried about by the currents and tides. They occur in almost all freshwater lakes, and especially in the open sea. They are perhaps less numerous in the "deep blue sea" far from the coast-line, though even there they are by no means entirely absent.

This free-floating life of the ocean is usually called plankton (the name includes the marine animalculæ which occur along with the seaweeds). They are commonest at a short depth, though they have been found rooo feet below the surface. In the Arctic and Antarctic Ocean depths of 120 to 250 feet seem to yield the largest amount. ${ }^{19}$

One can obtain samples of this plankton by attaching a small bag of miller's gauze to the taps of a sea-water 


\section{Seaweeds and Leaf-green}

bath on board ship, and the results are often exceedingly interesting.

There is a strangeness about this invisible swarming life of the high seas which is very fascinating. The so-called "Trades dust," of which samples were taken by Dr. Reinsch when going to Brazil, turned out to be one of these algæ (Trichodesma Hildenbrandti forma atlantica). Another species found by Ehrenberg in the Gulf of Sinai is responsible for the redness of the Red Sea. There are purplish, yellow green, and brown forms of this alga. ${ }^{20}$

The most abundant are probably the diatoms which form an isolated group of very curious little one-cell algæ. Each cell is enclosed in a little flinty case very strangely ornamented by artificial-looking dots and lines. Some are circular, others rectangular, some are torpedo-shaped, whilst others are quite indescribable without illustrations.

These diatoms are as important to the harvest of the sea as the grasses are to man and his domestic animals, for it is upon diatoms that those minute animals feed who themselves supply cuttle-fishes, ordinary fishes, and whales with daily nourishment.

There seems to be two crops of diatoms in most parts of the world, one in spring and the other in late summer, but on this very essential point our information is by no means clear.

In Southern Newfoundland, at depths of 5000 to 6000 metres (2500 to 3280 fathoms), there are extraordinary quantities of the dead shells of a circular form (Coscinodiscus radiatus). This is the place where the cold Labrador current mingles with the warm water of the Gulf Stream, and the consequence is a continual massacre of the diatoms which sink to the depths and are there forming the mud or clay of the bottom..$^{21}$ 


\section{Seaweeds and Leaf-green}

Such diatoms, even if they do escape the codfish, have not necessarily wasted their lives. Each minute cell contains a drop of oil, and such oil-drops accumulating in the muddy deposits may become infinitely valuable stores of petroleum.

"Chocolate creams" and "wax" candles made from them may be very useful and agreeable after a few more geological æons.

Almost as numerous sometimes are those very strange coccoliths which are also unicellular plants of the high seas. Their curious arms are possibly an attempt to defend themselves from minute enemies of some kind. In one sample of globigerina ooze, 68 per cent. of its weight and 7 I per cent. of its volume consisted of coccoliths!

Sometimes on a gloomy and quiet night, when the sea is a dark indigo-blue, one notices a very strange phenomenon. As the vessel's prow breaks the still dark water, the curling wavelets sparkle with faint lights for a second or two. It is especially well seen in the wake churned by the propellers, which is touched up with the faint phosphorescence for quite a long time. But every little ripple, as it breaks gently, is spangled with the same tiny sparks which one sees appearing and vanishing all over the surface.

These lights are generally due to a minute alga (Pyrocystis noctiluca), which, though small, is a very giant amongst its allies, for the single cell is from half to one millimetre long (.01968 to .03937 inch). There are many other phosphorescent plants and even animals.

They must be sometimes present in enormous numbers. Near Florida Dr. Schuitt estimated that there was a population of 50,000 in one square mile.

The spark is of distinct use to it, for when a pyrocystis sees that it is in danger of being gobbled up by some minute crustacean copepod, it gives out its tiny light 


\section{Seaweeds and Leaf-green}

and so baffles its enemy. The light would probably be just as effective as the searchlights used in the RussoJapanese war.

A curious experiment has been recorded which may yet have a practical application.

One fills an ordinary tumbler one-third full of alcohol (this is more than three-fingers or a third mate's peg, as it is sometimes described), and then adds as much seawater with pyrocystis in it as it will hold.

If one then gently shakes or jars the tumbler, the pyrocystis glow with most unusual brilliancy for a time, not exceeding four minutes; they then sink to the bottom of the tumbler and remain very quiet indeed for a very lengthened period!

One must imagine not only these few plankton algæ which we have mentioned, but many others developing regularly their one or two harvests, and being greedily devoured by many varied and remarkable marine freeswimming animals.

There are also the beautiful submarine meadows and thickets of the shore algæ.

The world of fishes feed upon the smaller animals which graze upon the diatoms and other planktons.

In fresh-water lakes one finds almost as varied and quite as beautiful a series of algæ. There are both shore forms and free-swimming plankton.

In the South of Scotland, the entire bed of a small burn or pond, every submerged stem of pond-weed, and every pebble may be covered with a curious golden-brown or dark brown mistiness.

One finds under the microscope that this is due to small diatoms attached by delicate and almost transparent threads of jelly, and which, when observed in their natural condition, are exceedingly beautiful. They also have regular seasons of development; some appear 


\section{Seaweeds and Leaf-green}

early and some late in the spring, others in summer, and yet others late in autumn. This is also specially true of the fresh-water plankton. ${ }^{22}$ The water may become turbid and quite yellowish-green through the swarming myriads; of algæ. A pin's head dipped in such a lake may bring up three hundred specimens.*

In examining such plankton algæ one is often almost startled by the large flaring-green and oddly shaped desmids which float across the field of the microscope. These also are one-cell algæ, and are of the strangest and most curious designs. Some are nearly circular, but slashed and cut so as to look more like the frostfigures on a window-pane than anything else. Some are thin crescents, or they may be triangular or rosettes, but generally of the same flaunting vivid green colour.

Many of them are provided with projecting harpoonlike arms, often with distinct hooks at the tip.

One would think on looking at these weird projections that here one has at last an example, so often looked for, of something which cannot possibly be of any service to the plant.

But this defensive armour of spiny projections has most probably been acquired as a means of resisting the attacks of their enemies. The amœba, which is nothing but a small piece of living protoplasm, cannot so well wrap its slimy body round such a desmid. There are also aquatic larve of insects and of small crustaceans to whom these spiny processes would be formidable! The desmids on wet rocks and such places as are not haunted by such enemies are usually without these spines. The reader is strongly advised to look through the illustrations in Mr. West's splendid monograph of the British Desmidiaceæ if he wishes to appreciate these points.

* Cooke's British Freshwater Alga. 


\section{Seaweeds and Leaf-green}

The algæ stand on the lowest level of plant life, whilst our flowering plants and ferns are the highest and best developed of all.

And yet although their anatomy is quite different, there are very curious parallels between this water vegetation and that of the land.

The Fucus' have root-like grasping fingers which take firm hold of the rock, and which seem to be distinctly sensitive to the touch of the stones. They have flexible tough stems and flattened leaf-like fronds.

Yet neither root, stem, nor leaf correspond in any way to those of the higher plants. Some of the elegant little red seaweeds have a pretty arrangement which looks like the bark of a land plant, but in these the "bark" is a series of flattened rosette-like branches closely covering the central thread of cells.

Moreover, these submarine plants have their parasites, and many small algæ seem to be seldom found except upon some of the larger kinds.

One of these is specially interesting, for it belongs to the algæ, and yet it has lost every particle of chlorophyll, and grows as a pure parasite on a common red alga (Rhodomela subfusca). ${ }^{23}$

So it corresponds exactly with the sickly yellow or white dodders and toothworts, which are flowering plants without chlorophyll and parasites upon other flowering plants.

1 Timiriaseff.

4 Jönnson.

7 Murray.

10 Ewart.

${ }^{13}$ Grafe.

${ }^{16}$ Kuster.

19 Chun, Karsten.

22 Zacharias, Koford, Willkomm.

8 Warming.

11 Catterina.

17 Schimper.

20 Reinsch.
2 Usher and Priestley. ${ }^{3}$ Ewart.

5 Blackman.

14 Friedenfeldt.

, Willk
${ }^{6}$ Gaidukov.

9 Lowenstein.

12 Macfadyen and Rowland.

15 Macfadyen.

18 Borgesen.

21 Lohmann.

${ }^{28}$ Moebius. 


\section{CHAPTER III}

\section{THE FIRST LAND PLANTS}

Although the algæ prefer for the most part salt or fresh water, many occur on land, and in the most unexpected and peculiar places.

Sometimes one sees a pebble lying on the seashore with a strange blood-red stain upon it. When this colouring matter is scraped off, it is found to be a minute parasite alga (Petrocelis or Hildenbrandtia). The greenish powder which covers old stems and branches of spruce and other trees consists of another alga (Pleurococcus). One may discover such landalgæe high up on boulders of Alpine craigs, on small stones exposed in a lowland pasture or on stone walls.

Perhaps the most remarkable of them is a moist, unpleasant, dirty green bubble-like jelly which appears after wet weather on gravel walks and stone walls. In dry weather it dries away and becomes almost invisible.

This is an alga, nostoc; the cell walls, which are in most plants very narrow, are in this group changed into a jelly-like material $*$ and are inordinately swollen. In consequence the tiny speck of protoplasm within them is very well protected against both vegetable and animal enemies. But we mention it here because of an interesting discovery, which was that such a patch of nostoc is able somehow to obtain nitrogen, not from

* This gelatinous substance is a modification of cellulose containing proportionately more molecules of water. It is also usually formed out of cellulose by water, and may be considered another case of fitting reaction. The slimy surfaces of all submerged plants are probably due to some similar substance. 


\section{The First Land Plants}

water but from the atmosphere. No plant can live on carbonic acid alone, for its living material contains nitrogen, sulphur, phosphorus, iron, and other elements which are usually obtained in solution by its roots.

There has always been a difficulty about explaining the nitrate supply of the vegetable world. The gas, nitrogen, in the atmosphere is not usually available for plants which can only, in most cases, absorb it in the form of nitrates dissolved in water.

The entire mass of dead vegetables and animals represent a sort of capital stock from which a living plant draws what it requires during life; its dead body and waste products go back to replenish the fund of available nitrogen. The chief object in the world of fungi and especially bacteria is to look after such dead matter and work it back into a form in which it can be absorbed by living roots.

Dr. Bunge has some very eloquent remarks upon this point. He complains of the wickedness of mankind in burning forests and so robbing the flower-world of its painfully acquired stores of invaluable nitrogen. He objects especially to cremation, which, in his view, is economically a crime. All explosives, such as gunpowder, are derivatives of nitric acid. So one might say that every shot fired, whether the bullet reaches a living being or not, destroys life, for it is a wanton destruction of combined nitrogen. All life depends upon this nitrogenous capital fund. ${ }^{1}$

But it is quite certain that vegetable life had a beginning, and this capital must have slowly accumulated out of very small excesses of income over expenditure.

It is in this connection that our nostoc becomes particularly interesting, for it was soon discovered that a certain bacterium (azotobacter) which lives upon this blue-green alga has the power of getting hold of the 


\section{The First Land Plants}

gas nitrogen and sharing it with the nostoc.* In return the nostoc gives up some of its sugary material or other product of carbonic acid to the bacterium.

The best way is to consider the two as friends (as one would understand this term in the City), that is, "business" friends.

The whole group of fungi were very likely at one time green algæ. Some of them, like the colourless alga, choreocolax, mentioned in the last chapter, found out a simpler and easier way of living as parasites, clinging to and devouring other algæ.

One might almost suggest that they trained themselves by the destruction of many green algæe until they became specialists and very expert in absorbing food material. At any rate fungi and especially bacteria are nowadays experts in the work of getting nitrogen and other salts from any kind of material, whether living or dead.

Somehow or other the azotobacter or its ancestors discovered how to seize the nitrogen of the air and turn it into nitrates and nitrites.

The two together, the nostoc and azotobacter, work as a co-operative company. They are now a mutual blessing; both benefit from the association, but yet, like some business friends, they are apt to become parasites, and require to be carefully watched.

After the discovery of azotobacter or nostoc, the mud of almost every ocean was searched for this interesting germ, and it has been found in Java, in East Africa, in Heligoland, and in the Baltic. $\dagger^{2}$ Swarms of

* Nitrogen, sulphur, carbon, coal, and peat are all oxidised by bacteria. How it is done, no one has explained. Nitrates are formed in the atmosphere by electric discharges (lightning flashes). Is it possible that bacteria produce it by electrical activity?

+ Bacteria occur in small numbers in sea-water, but not apparently below Ioo fathoms deep. 


\section{The First Land Plants}

this valuable azotobacter were found nestling in the slimy surfaces of ordinary seaweeds, living on their sugar (mannite) and supplying them with nitrogen. ${ }^{3}$ It even occurs on the exquisite fresh-water alga, volvox, whose little hollow spheres of bright green cells revolve cheerfully in the water to the vigorous wrigglings of its myriads of small oar-like cilia.

Before this discovery, it had been known that some bacteria had this power of obtaining nitrates. There are especially certain forms which live on decaying vegetable matter in garden soil or amongst leaf mould which accumulate nitrates. Of these the most important are Closterium Pasteurianum (discovered by Winogradsky) and the "alinite" bacillus of Kruger.

Of course in practical agriculture such microbes are of the greatest importance. It was not long before people became enthusiastic over the fascinating ideal of sowing bacterial seed and so adding, inexpensively, an enormous increase to the fertility of the soil. But the alinite bacillus has not yet been domesticated; it has only been kept in activity.

Another nitrate-forming bacillus has been recently very well advertised in the English papers. Its history is most interesting. Pliny was aware that certain crops, peas, beans, and lupines, improve the fertility of the soil instead of impoverishing it. "The Bean ... fertilises the ground in which it has been sown as well as any manure." This fact was also mentioned by Thaer in I 809 , and has been completely confirmed by the experiments of Lawes, Gilbert, and Pugh. ${ }^{4}$

So a simple method of enriching the soil came into use which consists in sowing down peas, lupines, or other legumes, and ploughing them into the soil. This is quite a common practice in Germany.

For instance, 224 kilos. (about $4 \frac{1}{2}$ cwt.) of nitrogen 


\section{The First Land Plants}

were added to the soil (per hectare, that is, $2 \frac{1}{4}$ acres) by common vetch, 205 kilos. (about $4 \mathrm{cwt}$.) by peas, and I 5 I kilos. (3 cwt.) by lupines, in some recent experiments. ${ }^{5}$

Now on the roots of all these leguminosæ, one finds odd little gall-like swellings or tubercles, which have been investigated in many famous and classical researches. The first to explain them clearly seems to have been Schindler in I884, who suggested that they were due to bacterial "friends." Then in 1888 , Hellriegel and Willfarth showed satisfactorily that bacteria formed the swellings, and that these bacteria obtained nitrogen from the air, and so handed it on as nitrates to the plant.

Pliny, Varro, and theother practical agriculturists were thus shown to have anticipated our modern discoveries.

The next point was to domesticate and utilise these germs in ordinary garden and field work. But the difficulties were great.

These microbes have peculiar tastes. A vetch tubercle bacillus (Pseudomonas radicicola is its proper style) dislikes growing on beans or on anything except vetches. The vigour or virulence of the microbe varies. Sometimes, when in captivity in a test-tube or on cotton-wool, it becomes weak and languid, and refuses to work or suddenly dies. And sometimes it gets far too strong, and robs its vetch or bean-root of the nitrate obtained by the roots.

In good garden soil there are probably millions of pseudomonas germs, and the question at once occurs, Why then go to great expense in introducing it ? But at first sight one would think that on poor or inferior soil, especially where no leguminosæ had been grown for some years, there might be some advantage in using artificially bred bacteria. 


\section{The First Land Plants}

One form of culture of these germs, "nitragin," was actually made and sold on a commercial scale. This was prepared after the suggestions of Nobbe and Hiltner. It is no longer manufactured in bulk, though even in 1903 the last named declared that of 98 inoculations, 83 per cent. were successful, and only 9 per cent. failed. ${ }^{6}$ On gravelly sand, on clay and on peat, Dawson found that nitragin was of some service, but it was worse than useless on garden soil and on sand.?

The American "nitroculture" distributed by Moore is said to have in one case doubled the harvest of vetches. When cut green the inoculated crop amounted to 23 tons per acre, and that not inoculated to I I tons 7 cwt. per acre. But there seem to have been many failures.

Professor Bottomley in 1906 and 1907 produced " nitrobacterine," which also is a living culture of these germs. His efforts were very energetically assisted by the newspaper press, which in scientific inventions of British origin is most encouraging.

According to his own statement, he obtained himself yields of 50 per cent. more nitrogen from inoculated plants. In field experiments i 2 tons 5 civt. of fodder (tares) were got per acre from nitrobacterine and 9 tons 8 cwts. per acre from nitrate of soda. ${ }^{8}$

One could hardly imagine a better place for such inventions to be tested than the Royal Horticultural Society Gardens at Wisley and a very elaborate series of experiments were carried out there in I908. The results were that the total weight of the crop from seed which had not been inoculated was heavier by 14 per cent. than that got from the nitrobacterine seeds.

In some soils the decrease due to inoculation was far more than this (even 27 per cent. in the weight of peas), and though there were instances of an increase in 


\section{The First Land Plants}

crop through inoculation, the evidence seems on the whole distinctly against nitrobacterine. Every attempt seems to have been made to make the trial as complete and as fair as it could possibly be. ${ }^{9}$

But though all these three cultures (nitragin, nitroculture, and nitrobacterine) are found to-day not to answer when tried commercially by ordinary gardeners and farmers, the ideal of a tamed bacterial population which one can cherish in test-tubes and sow carefully in spring-time with a distinct prospect of an abundant harvest will assuredly be obtained if only people will not be discouraged by these repeated failures.*

But nitrates form but one of the many salts which must somehow be gathered in by the roots which have to provide a constant stream of water for all the growing or active cells.

The layer of soil upon which plant life depends is exceedingly thin. It is hardly ever more than a few feet, and often is but a very few inches in thickness. But one requires a touch of imagination, of sympathy with bacteria and with earthworms, if one is to at all appreciate the wonderful character of the processes at work.

The earth itself is porous and crumbly, made up of tiny sharp-edged particles utterly irregular in shape, varying in size, and of the most different constitution. Some are organic, others inorganic; there may be particles of sharp quartz which have defied plant action from the beginning of the world, and beside them silt or sand fragments which have been devoured by worms, rolled by water, attacked by acids, and utterly transformed in every geological period from the Silurian to our own days. One has first to realise the labyrinth of

* Full details of the tubercle bacteria will be found in Chittenden, l.c. ; also Bull. U.S.A. Agriculture Plant Industry, 71, 1905, and especially Jacobitz, C. B. f. Bact., Jena, Igor Nos. 22-24. 


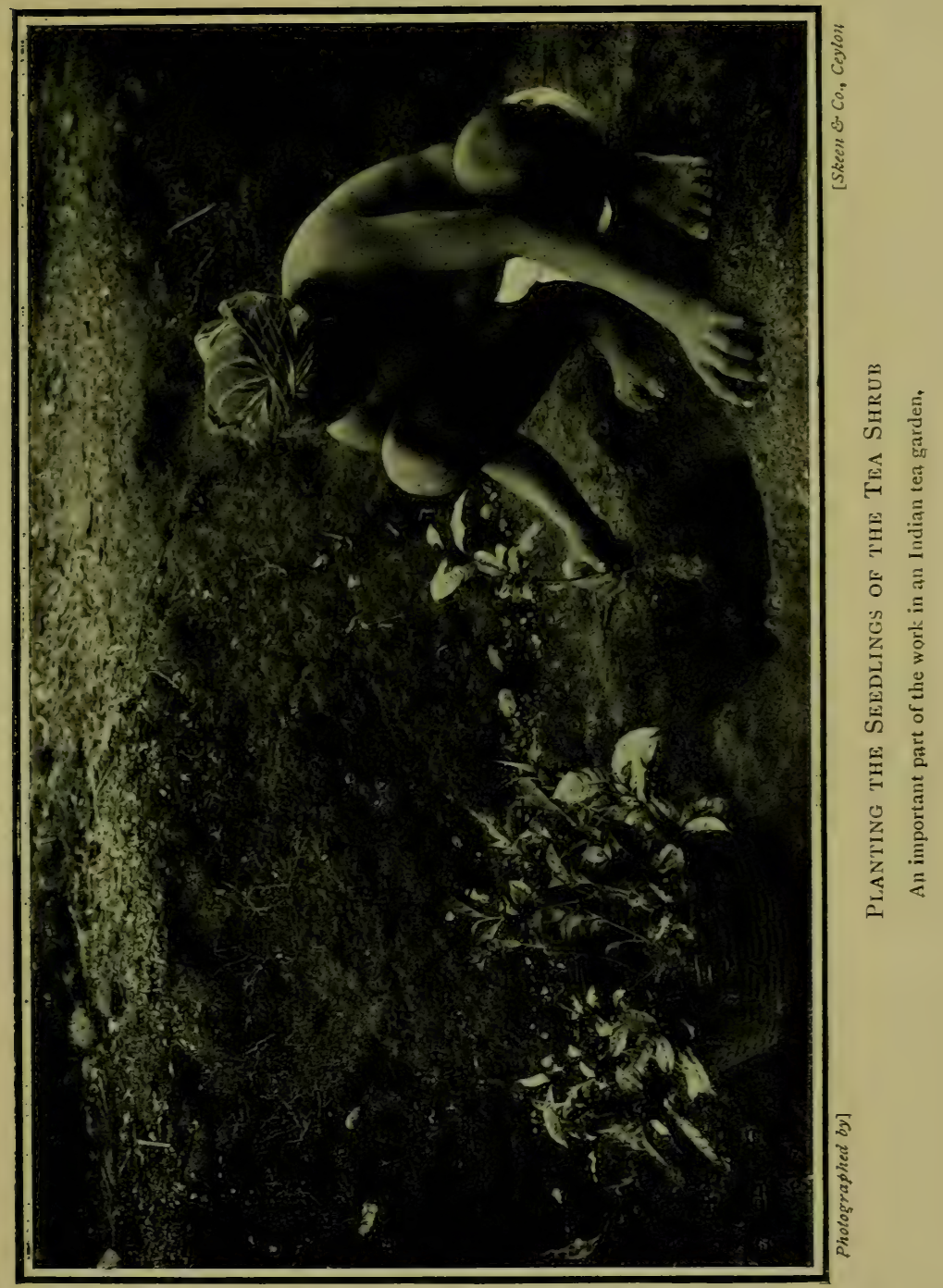





\section{The First Land Plants}

minute grottos and irregular winding fissures which penetrate in and amongst these particles. The total surfaces of these minute subterranean hollows must be enormous. Let us take a very simple case and suppose that all the earth particles are small spheroids one thousandth of an inch in diameter. It has been calculated that with such a soil the surfaces of all the particles in a cubic foot of earth would amount to at least one acre. A thin film of moisture lines and carpets all these internal hollows, cracks, fissures, and miniature grottos; in this moisture the reader must imagine a liberal sprinkling of bacteria, for there are at least 100,000 in one gramme ( 15.432 grains) of garden earth.

Some of these are actively squirming or cork-screwing their way through the watery film, others are motionless. They are certainly small, for one could pack about $1,700,000,000$ of ordinary bacteria in a cubic millimetre of water without inconveniently crowding them.*

Some of these germs are benevolent, and will be breaking up the bodies of deceased insects, leaf mould and the like; others may be closterium or azotobacter forming nitrates: but many are malignant typhoid germs, or vegetable fiends. Here and there one might see running through some of the caverns the exquisitely divided and finely branching threads of a mould fungus ; in another place a plant's root-hairs and exploring rootlets which may be themselves clothed in a fringing mantle of fine fungus threads.

* A cubic millimetre measures about $\frac{\lambda}{25}$ th of an inch each way. There are giant bacteria $30 \mu(30 \times .00003937$ inches) thick, but the smallest are about $.4 \mu$ in diameter (.00015748 inch). Errera ${ }^{10}$ in an interesting paper tries to show that we cannot imagine any bacteria less than . OI $\mu$ ('000003937 inch), for it could only contain some ten molecules of albuminoid. This is in a way encouraging. 


\section{The First Land Plants}

All these rootlets and fungi are searching and probing patiently every film of moisture and absorbing the salts contained in it.

Now and again a worm is encountered stolidly eating its way right onwards and swallowing all sorts of vegetable, animal, and mineral matter. Inside its body there are chalk glands and bacteria which are working up its aliment, and the residue will form the worm-casts deposited on the surface when the worm comes up in the evening.

The circulation of air in these underground passages and grottos is rapid and complex.

Everything alive is breathing in oxygen and giving off carbonic acid. The more oxygen there is the more energetic and intense is the life of every microbe and fungus and root and worm and insect. So, for instance, the azotobacter will form more nitrate, the worm will eat faster, and the roots will absorb more water. ${ }^{11}$

As all these living things are taking in oxygen they must, necessarily, give out carbonic acid, which will be evaporating from the surface. The bacteria of one hectare would alone give off some $75 \mathrm{~kg}$. per day (that is, $6_{5}$ lbs. per acre nearly). ${ }^{12}$ This will go to replenish the carbonic acid supply of the green leaves. But some of the carbonic acid given off by roots and by fungi is employed in rendering soluble such refractory and stubborn minerals as silicates and aluminates which contain perhaps minute particles of valuable salts. This is another and unexpected "fitting reaction," for the carbonic acid is a waste product, and yet it is used to furnish food to the living plant!

Now suppose heavy rain falls steadily and for days together; the soil is saturated, so that the air is exhausted and perhaps millions of bacteria unintentionally commit suicide by carbonic acid poisoning. Others 


\section{The First Land Plants}

hurriedly form spores and await better times. The whole complex life of the soil is almost at a standstill.

Then the rain stops, and sun and wind dry up the surface so that the water evaporates and the air passages become free again. Then at once, with the advent of revivifying oxygen, the whole complex machinery of underground life awakes again to vigorous activity and is in full working order.

Catastrophes are often blessings in disguise, as, e.g., a hard frost, which not only pulverises the soil but is in the end most beneficial.

The fungi vanish, turning black at the first touch of frost ; the leaves and stems of summer herbaceous plants fall off or become sodden, flaccid, and horrible, and nothing is left but the roots and underground stems, with their carefully stored up starches and proteids.

The bacterial population is massacred wholesale, for only a few of the strongest and hardiest microbes refuse to be killed.

But when the spring comes, the new bacterial races are all specially selected stocks, and the best of their kind. So also are the fungi, and even the weed-seeds and flower-roots. It follows that the new population starts strong and efficient on another year of adventure and hard work, for all its forefathers were healthy and sound.

When, for instance, such a manure as carbon bisulphide is used on arable land, the first result is a horrible diminution of the bacterial population, but after a time the bacteria begin suddenly to increase in numbers and flourish exceedingly. This is explained by the fact that all except the very strongest have been slain.

In a recent report on the grouse disease on overstocked moors, the usual sequence of disastrous years, followed by a sudden run of good seasons, seems to be 


\section{The First Land Plants}

best explained in the same way. The new stock are all a strong selected race, and all weakly birds have been killed out.

One might, I think, find many facts in the history of man which are explained in the same way, such as the development of modern Germany after the FrancoGerman War ; but this is far too difficult a subject to discuss here.

Yet there are gloomy and depressing facts connected with this population of bacteria. Amongst these microbes there are not only friends but deadly enemies, such as typhus and anthrax, which can live happily and are ready for work after 500 days in garden earth. ${ }^{13}$

Radishes, cress, and other garden vegetables are probably scattered over by such germs, which are not killed by ordinary kitchen manipulation. ${ }^{14}$

We have to thank M. Baudouin for another ingenious and perfectly horrible suggestion.

When exploring a well or rubbish pit belonging to the Gallo-Roman period, he discovered some suspicious mud. In this he found several dangerous diseasebacteria, and kindly points out that by living in a halfcomatose condition, they were still prepared to start a dangerous epidemic after 1800 years in the bottom of a well. ${ }^{15}$

Fortunately eminent bacteriologists hastened to reassure the public mind by declaring that these bacteria were only our own contemporaries, who had got into the well with the rain-water. So that this awful foreboding of thousand-year-old bacteria still waiting to prey upon us need not alarm the most sensitive person.
1 Jacobitz.
2 Otto and Newmann.
${ }^{3}$ Reinke.
- Lawes, Gilbert, and Pugh. ${ }^{5}$ Pitsch. ${ }^{6}$ Hiltner.
8 Bottomley.
${ }^{9}$ Chittenden.
10 Errera.
12 Reinke.
13 Konradi.
14 Clauditz.
Dawson.
11 Pfeiffer.
15 Baudouin. 


\section{CHAPTER IV}

\section{BACTERIA}

THE world is everywhere pervaded by bacteria; minute microbes are carried by the atmosphere, they float in the water and occupy the soil. When we or indeed any other animal take our walks abroad, we create and are surrounded by an invisible halo of bacteria; some are stirred up by the dust of our going, others shaken from our clothes, and others are even distributed by our breath. They are scattered over the food which we eat; the water which we drink is full of them, and as a matter of fact it would seem detestably vapid if it was germ-free.

These germs form a very mixed multitude : some are distinctly useful and even necessary forms, others are harmless, and a few are malignant and fatal diseasebacteria.

In order to study any particular variety, it is necessary to keep it from being contaminated by some of the numerous wild forms. The methods in use require very careful manipulation; the germ is grown upon gelatine, on peptone broth, or on agar-agar (a seaweed preparation), and atmospheric germs are carefully excluded from the test-tube or glass shells in which the "culture" is preserved, usually by a cork of cotton-wool.

Dr. Kienitz Gerloff ${ }^{1}$ made an interesting experiment with one of his sterilised or germ-free agar-agar saucers. He persuaded a healthy young maiden (gesundes junges Mädchen) to imprint a hearty kiss upon this unfeeling 


\section{Bacteria}

seaweedy surface, and at once covered it with its glass lid and put it aside to incubate.

In two days there were about fifty colonies of bacteria growing upon it, and all the result of that momentary operation!

It is not surprising to learn from Dr. Kienitz Gerloff that in Virginia and Chicago a byelaw has been proposed which strictly forbids kissing under any circumstances whatever, not because the authorities wish to emulate Mr. Dowie, junior, but simply because it is an inherently insanitary and unhealthy operation. But the byelaw has not as yet been passed, at least so far as we know.

But, whether one is afraid of them or not, one must just live on swallowing millions of germs, drinking them by the hundred thousand, and even breathing them into the lungs. What we have to do is just to trust to those white blood corpuscles which patrol our bodies, and to hope that they will succeed in overcoming and in digesting away even malignant or unnecessary bacilli.

It is of course very difficult for a layman to say anything at all about the abstruse discoveries of modern bacteriology without making mistakes, but the subject is far too interesting to be altogether omitted in any account of the botany of to-day.

The losses of mankind in war or by famine are quite insignificant when compared with the death-roll due to malignant and disease-bacteria.

But as the years pass on, men are gradually learning first to understand and then to get the mastery over them. One minute and deadly germ after another has fallen under his control, so that the promise of the future is distinctly encouraging.

What has as yet been done is of course but an infinitesimal part of a gigantic undertaking. 


\section{Bacteria}

The habits and way of life of some bacteria are very remarkable. One great group of them is unable to exist in free oxygen, but obtains what oxygen they require by the alcoholic fermentation of sugar and allied material. They and the other fungi and plant cells which act like them are therefore responsible for alcoholism.

Sunlight at once destroys most bacteria. A young (three hours old) Micrococcus prodigiosus dies in one minute of sunlight. Old colonies (that is, ten to fifteen hours old) may survive longer but are killed in three to five minutes. ${ }^{2}$

A colony or "culture" of bacteria isolated from the world in a test-tube or glass shell, and growing in bloodserum or peptone broth, not only extracts and absorbs from this liquid or jelly whatever food it requires, but also excretes out its own waste products. This is just as necessary for bacteria as for any other plant or animal. As we saw in the last chapter, carbonic acid is a waste product excreted by plant roots, and is in excess poisonous to them.

A disease germ living in an animal's body gives off a series of complex waste products or toxins which are deadly poisons to the animal cells. The dead substance of these poisoned cells is then absorbed as food material by the bacterium, which in consequence thrives and multiplies.

When cultivated artificially in test-tubes or glass boxes (Petri's shells) a colony of disease germs will in process of time exhaust all the food material in its little "world" or test-tube, but it will become itself diseased and die long before it has done so, for its own waste excretions will have so pervaded and poisoned its world that it becomes uninhabitable.

Pasteur suggested that when disease germs in an animal body eventually die out, as is found to be always 


\section{Bacteria}

the case, the reason is because they have either exhausted all the food that they can get in the body or else have made it uninhabitable for themselves by their own poisonous excretions. These theories leave, however, out of sight a very important side of the question.

The cells in the animal's body when a bacterial enemy invades it are not dead but alive, and invariably make some sort of effort to resist them.

The only possible answer for such a live cell in an animal body is to fight a poisonous bacterial excretion by secreting something else. Such mysterious defensive secretions are called anti-bodies, and may either be antitoxins, which neutralise the toxins (that is, bacterial excretions), or they may be bactericidal bodies which kill the bacteria themselves.

This response of live cells to bacterial enemies is another clear case of "fitting reactions."

We are obliged to mention here a rather disturbing and agitating fact with regard to our own bodies, but the reader must please consider it in a bright and hopeful spirit. There are, wandering everywhere within our own bodies, multitudes of white blood corpuscles or phagocytes, whose duty it is to destroy and devour any objectionable microbes that have managed to enter us. We have no control over these phagocytes, who are entirely free and independent.

When a foreign bacillus has entered our body, it begins to give forth its poisonous excretions ; these penetrate to and eventually reach a phagocyte. The whole of the latter's protoplasm is at once on the alert ; stimulated and "anhungred" by the trace of this secretion, forthwith it proceeds, crawling as rapidly as possible, towards the bacillus until the supreme moment arrives in which it engulfs or enfolds the unfortunate microbe within its own jelly-like body and promptly digests it to death. 


\section{Bacteria}

Nor are the other live cells of our body mere passive spectators of the prowess of their police phagocytes. They do what they can and secrete mysterious substances called opsonins, which somehow paralyse or entangle the bacillus so that it falls a helpless prey to the "polymorphonuclear leucocyte," which is the correct style and designation of the phagocyte. ${ }^{3}$

Not only so, but those tissues which are set apart for the production and formation of phagocytes, work more energetically when a bacillus invasion is proceeding and turn out a much larger number of phagocytes than usual.

There is a strange difference between individuals in these matters. The bodies of certain people are rich in opsonins, so that they are well able to resist bacteria, whilst others are decidedly feeble and weak "opsonically." The researches of Messrs. Leishman and Wright must be consulted for further details as to the "opsonic index," \&c.

There are several methods by which people can be made immune to some particular infectious bacterium. One ingenious method consists in first isolating your race of bacteria and then turning that race into a feeble and inefficient variety, which will do no great harm to the individual but yet prevent any subsequent accidental invasion of the original wild bacterium from establishing itself.

Such a wild germ would find the food material exhausted and the ground poisoned by the feeble race which preceded it.

Pasteur's method with the germ of hydrophobia consisted in exposing the colonies for a greater or less period to a current of air. The results of his experiments are quite remarkable.

Before 1886 , I 6 per cent. of all persons bitten by 


\section{Bacteria}

mad dogs died under the most horrible circumstances. Between r 886 and 1897 , I7,337 cases have been treated under the Pasteur system, and the mortality is only 4.8 per cent., less than one per 200 cases.

Should any one be bitten by a mad dog the wound should be cauterised as quickly as possible, and then the patient should travel to the nearest Pasteur institute as quickly as he possibly can.

When people are vaccinated by the ordinary method, the relatively feeble cow-pox germ enters the body, calling up armies of phagocytes and quantities of antitoxins or both. If the person is infected by a real smallpox germ the latter finds itself unable to make any progress.

People forget now-a-days the number of deaths from smallpox, and the horrible disfigurement which used to be common enough but which one never sees nowa-days.

In the larger German towns vaccination was compulsory from $\mathrm{I} 885$ to $\mathrm{I} 887$, and the mortality from smallpox was one per 200,000 . Taking the same period the deaths from this disease were in Hungary 236 , in Italy 100 , in France 78 , and in Austria 74 , all per $200,000 .^{3}$ Vaccination was not compulsory in these countries though no doubt often employed, for it was discovered a long time ago (by Edward Jenner, I 749-I 823).

Other methods of resisting bacteria are equally ingenious.

Sometimes the disease germs are imprisoned in capsules and placed in the body so that only their poisonous toxins enter the system and not the bacilli themselves. This calls into existence antitoxins which preserve against an accidental infection. The serum of some animal which has outlived the particular disease is sometimes 


\section{Bacteria}

injected into the patient ; it is supposed that this serum contains antitoxins which will help the sick person to resist his bacterial foes. For other details on this interesting subject the reader must be referred to, e.g., Muir and Ritchie. ${ }^{4}$

There are so many other interesting questions connected with the world of bacteria that it is difficult to make a selection.

There are at least twenty-six species of bacteria and some twenty kinds of fungus which are phosphorescent, so that the algre are not alone in this curious accomplishment.

Amongst the fungi, the commonest species is Agaricus melleus, which is capable of making an old dead tree glow after a very strange and ghostly manner. The light from cultures of phosphorescent bacteria is not of a dazzling character, but a quiet phosphorescence with faint tints of blue green or violet. Even in broad daylight one can distinguish it in the dark corner of a room. Living lamps have been made by growing these bacteria on gelatine in glass flasks. Professor Dubois had one at the Paris Exhibition in I900, and Professor Molisch had a splendid specimen at the Carlsbad Congress of 1902 .

This lamp will remain alight for fourteen to twentyone days, and can be used as a night light, or even to read one's watch or very large print. One can even take a photograph by it, but yet it is not likely to be a good commercial light, for one would require something like 2000 square yards of bacterial cultures to get one candle-power. ${ }^{5}$

If the reader wishes to see these curious phosphorescences, it is only necessary to rub fish (not too fresh) with a piece of raw butcher's meat and place it in a 3 per cent. solution of common salt. 


\section{Bacteria}

These living glows must not be confused with the strange little flashing lights sometimes seen on the tuberose in India, especially on very hot evenings. This has not yet been explained, but seems to be due to electric flashes.

Spontaneous combustion, such as may happen to hay and straw when stored in too wet a condition, is the work of certain bacteria. On such damp grass stems huge quantities of micro-organisms begin to grow and are supplied by the organic matter diffusing out of the hay. All these germs as well as any cells still alive in the hay are actively breathing, taking in oxygen and giving out carbonic acid. ${ }^{6}$ Any heat produced is retained, and the temperature gradually rises until the whole stack bursts into flame. This is a special danger on board ships laden with cargoes of cotton and other vegetable matter. One of the bacilli lives at temperatures of $50^{\circ}$ to $60^{\circ} \mathrm{C}$, and its spores can resist a heat of $100^{\circ} \mathrm{C}$.

Besides light and heat, beautiful colours and strong perfumes are often due to bacterial workings. Some of these latter scents remind one of ripe strawberries; the "marigold" smell of African rivers described by Mr. Kipling is also a bacterial bouquet.

The colours are often quite vivid and beautiful. There are several rich reds and pinks, of which the crimson Micrococcus prodigiosus, with its extraordinary resemblance to freshly shed blood, is the most interesting. This is often to be seen on bread and other provisions. Milk may become a deep blue, and there are also light blues and purples and yellows; a beautiful fluorescent colour is formed by Bacillus lactis aerogeneus." Glue may be turned into a deep black colour.

Perhaps the prettiest of all is the rich golden russet 


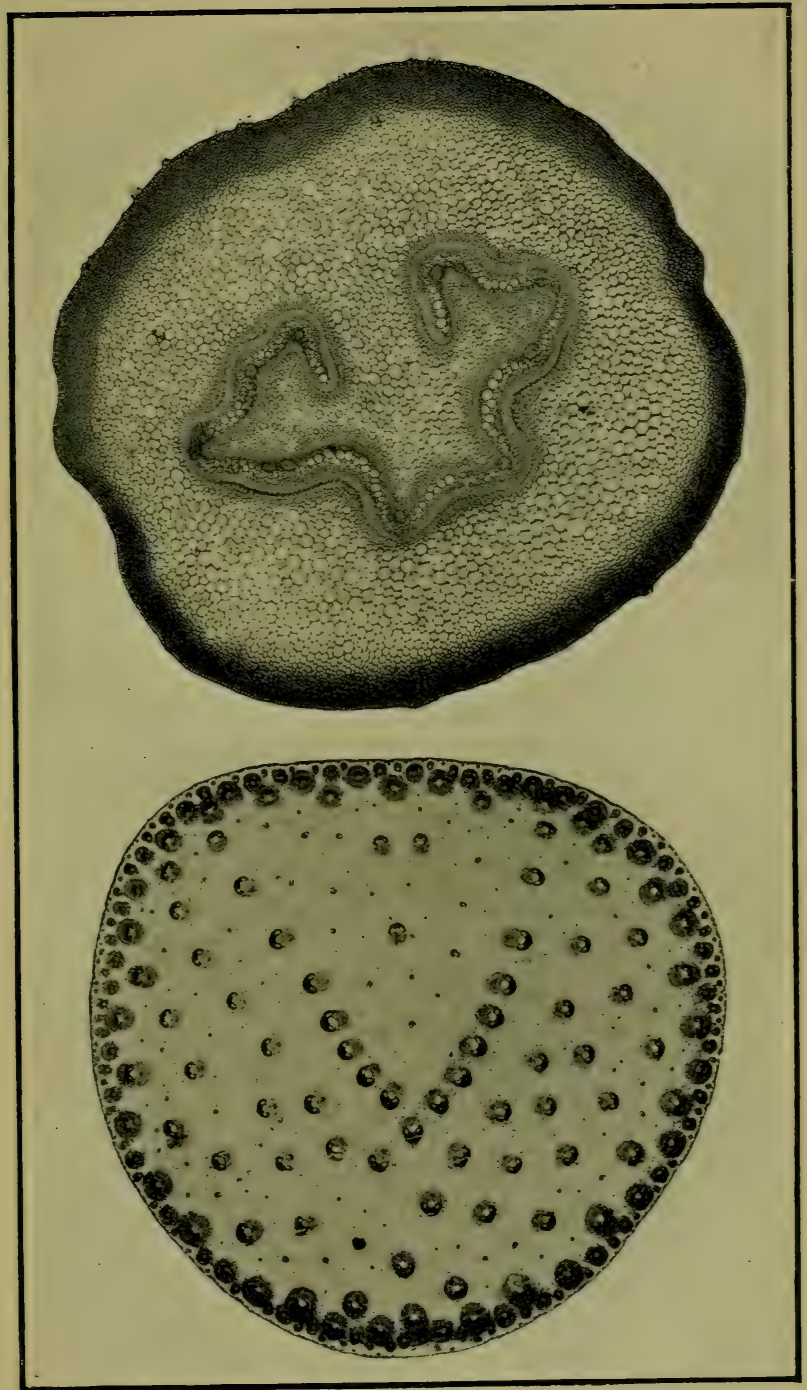

Photomicrograph

A. E. Smith

Stem of Fern (above) and of Rattan Cane (below), showing an extraordinary amount of specialisation in the cells. 



\section{Bacteria}

of several Iron-bacteria, which form the peculiarly unpleasant-looking slime in the stagnant water of marshes where there are iron-pipes.

There are but a few examples of the manifold activities of these minutest of vegetable organisms. It is really impossible to do justice to them in a short space. It is they who especially take charge of all dead vegetable and animal matter, which they thoroughly break up and work down to some simpler chemical condition, in which it can be again used by the vegetable world. Their small size and wonderful rapidity of growth enables them to do this in a very efficient manner.

A single bacterium will grow up and divicle into two bacteria in the space of 20 minutes. So that in one day of 24 hours, the progeny of one bacterium would be $2^{72}$, which is exactly $4,722,366,482,869,645,2$ I 3,696 individual germs. Indeed in a very few days the whole earth would be one weltering mass of bacteria if all the descendants of a single microbe continued to live and multiply at this unconscionable rate. But this is an unlikely thing to happen, for they require food material, and would very soon commit bactericide by carbonic acid poisoning.

Cheese, butter, curds and their various varieties are due to special bacteria. In concert with yeasts and some other fungi they produce many fermentations, and especially assist in making beer, wine, ginger-beer, and vinegar. It is they also who spoil and destroy the same deleterious drinks. Tobacco is the result of bacterial activity. The making of hay, ensilage, and linen, or the tanning of raw hides, can only be carried out with the help of bacteria. The art of man in all these cases consists in checking their action at the moment when some useful substance has been pro- 


\section{Bacteria}

duced. If not so checked, the process would go on until the substance is so transformed that it can be again used by plants. So that bacteriology is a very valuable science, and perhaps one that has the most promise for the future of all the sciences.

When first one sees them under a microscope, one ought to be impressed by the untold possibilities for good or for evil of these minute living atoms.

An unfortunate laboratory attendant and two nurses lost their lives because a few plague-bacilli escaped from their glass tubes. When one sees the rows of cultures in a bacteriological laboratory, one realises the infinite dangers which are daily encountered by so many scientists.

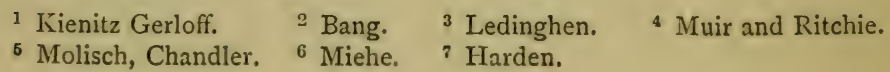




\section{CHAPTER V}

\section{ROCK LICHENS}

WHEN passing along a sheltered winding road a very unusual colour may be sometimes seen on the old walls or dry stone dykes.

It is particularly noticeable when the sun's rays strike along the wall, as happens late in the afternoon in autumn ; then the irregular stones seem to glow with an unearthly colouring which is quite unlike any other of Nature's effects and is most impressive.

It is not easy to find a word which will exactly express the shade, though perhaps golden-tawny or russet-orange may give a faint impression of it ; but it is not a flat but a velvet-like covering which touches up the surfaces and extends into the crevices and recesses between the stones. ${ }^{1}$

When one examines the wall carefully, one finds a brown fluff scarcely $\frac{1}{12}$ th of an inch in thickness, and which is even more exquisitely beautiful when seen under the microscope. This is a minute tufted Alga chroolepus or trentepohlia. ${ }^{1}$ One wonders if there is any microscopic eye belonging to some artistic insect which is capable of enjoying such an exquisite little plant. This is not unlikely, for these chroolepus have a faint yet agreeable perfume, in which respect no other algæ resemble them. The ordinary "forgotten" seaweed smell is one of the most abominable in the world.

Small insects can be seen wandering over the velvet 


\section{Rock Lichens}

pile of the chroolepus, and these no doubt distribute its spores.

But the interesting point about chroolepus is that this minute growth of $\frac{1}{6}$ th to $\frac{1}{12}$ th of an inch is like a miniature heath, and forms a very complicated little association of its own.

Each little upright branching alga with rich goldenbrown or orange twigs rises out of a sort of turf composed of dead algæ, fungi, insect-corpses and dust.

Here and there one sees a fallen chroolepus "tree" lying on the turf and covered or encrusted by slatecoloured fungus filaments, green cells of Pleurococcus and the like. It has an odd resemblance to a fallen log in a wood covered with mosses, ferns, and flowering plants.

Swarms of bacteria also occur in the basal turf. If one could get a mind small enough to appreciate the chroolepus heath, it would be indeed a weird and wonderful place. It is submerged (like the Amazon valley) in heavy rain, and one would then see the brilliant, pear-shaped, orange-brown spores violently hurling themselves about through the branches by means of their double whiplike processes.* There are Nematode worms like great pythons crawling through it: strange transparent sluglike animalculæ are perceived, on intrinsic evidence, to have been grazing on the branches. The parasites on the trentepohlia are varied and beautiful. Gold-brown, artificial-looking diatoms and green algæ are wrapped round some of them, and the slender deadly threads of parasitic fungi creep and twine everywhere.

But as the reader can quite well examine such trentepohlia associations for himself, it is unnecessary to give more details.

* The motion is difficult to describe. If one cracks a long Australian stockwhip, it is difficult to keep one's feet. The spore lets itself go. 


\section{Rock Lichens}

We have given so much because this lowest of all associations brings out a curious mixture of co-operation and competition. Each individual, plant or animal, is attempting to overgrow or to destroy its neighbour. But yet one might say that every form is directly or indirectly of service not only to its neighbours but to the trentepohlia association as a whole (see Chap. I.).

At the edge of such trentepohlia crusts, however, the green feltwork of pioneer moss protonemas may be found crawling over the heath. Moss tufts will eventually occupy the stone surface which has been first worked over by trentepohlia.

One might venture a little farther and say that Nature is by no means careless about the individual bacterium or trentepohlia. Very ruthless methods are employed to take care that it is a thoroughly adequate bacterium. If not, the minute research by which its body is investigated insures that everything which it has formed during life is available for the common good. But on most walls, on exposed mountain rocks or in the cold rock-deserts of the far north, one finds not trentepohlia but lichens.

These lichens are double plants consisting of a fungus "body" which contains a green layer of resident algæ. They ought theoretically to have a double name (that of the alga and that of the fungus), but this is quite unnecessary in practice.

These lichens are exceedingly hardy and can live, e.g., on black rocks jutting out of an Alpine snow-field. In a wild part of Dalmatia known as the Karst, the rocks are exposed for hours together to a blazing sun, and yet, though the temperature on the surface may be $58^{\circ}$ to $60^{\circ} \mathrm{C}$., lichens occur on them.

These, the hardiest of the group, are usually mere stains or crusts upon the rock surface, generally grey 


\section{Rock Lichens}

or neutral-tinted, though one finds black, bright yellow, cream colour, and various rusty and leaden shades, mouse colour, or sometimes pure white crustaceous lichens.

The variety of their tints is very remarkable, though to see them properly it is necessary for the eye to be only a very few inches from the surface. But when one is closely scrutinising lichen-covered rocks, the interesting point is the colour of the tiny sporecups or apothecia, which are always an effective contrast and yet in harmony with the body colour. Hæmatomma is exceptional in its vivid crimson (against pure snowwhite), but the reddish-yellow, ghostly pale, or bright egg-yellow of other crust forms are always pretty and interesting. On rocks even in much exposed summits in the Highlands there are also a few of the leafy kinds, such as Gyrophora, which looks like a badly made rosette of brown paper which has been blackened in the fire.

But most of the leafy rosettes and circular patches of grey Physcias, Parmelias, \&c., are found on old walls, or on the branches of badly grown trees.

The upright little "cup and trumpet" lichens, Cladonia, are mostly white or grey, and have bright crimson or rich chocolate-brown sporecups. These are very characteristic of dry, peaty ground, and may almost entirely cover the turf and the base of the heather stems in a dry moor.

Perhaps the most advanced of them all are the Old Man's beards (Alectoria and Usnea), which give a weird and impressive appearance to some ancient pine forests. In such old woods one may find the crannies in the bark of a very old trunk coloured yellow with another rare lichen, whose black pinlike sporecups may be found on very careful examination. 


\section{Rock Lichens}

So that it will be seen that, though lichens are characteristic of rocks, they also occur scattered or as dependents in some of the higher associations.

The field botanist will find them exceedingly difficult, especially the crustaceous ones, for of Lecanoras, Verrucarias, and Lecideas there are some 700 species, and there are not ten botanists in Britain who are capable of naming them correctly. ${ }^{2}$

The brilliant colour of the cups, and sometimes of the lichen itself, has been already noticed. Is it not curious to find reds, yellows, and pale colours in connection with their reproductive spores? Similar colours appear in flowers which are in no way related to lichens.

It is, at least in the author's opinion, a fact that insects are attracted to those cups and carry the spores. The flaring yellow of Physcia parietina is very conspicuous on seaside rocks. No fly could help proceeding to one of these patches, and it would surely then visit the conspicuous little bright sporecups.

But there is no explanation of how the colours were formed. In these sporecups, when forming, there is possibly the same relatively intense respiration, higher temperature, and greater production of food material that are also characteristic of flowers (see p. I I I).

One point about lichen-life is the importance to them of atmospheric dust. This is of the most varied character and very mixed in origin. A small amount of nitric acid is said to be brought down with rain-drops (due to electric discharges); there are also dust particles from roads, from volcanic eruptions, from the smoke of towns, and indeed gathered up from everywhere.

Mr. Aitken did on one occasion find a cubic centimetre (.06I cubic inch) of air which contained only one dust particle, but this was only once, and from the 


\section{Rock Lichens}

very top of Ben Nevis. ${ }^{3}$ Amongst the dust there will be pollen grains, * bacteria, fungus spores, and especially yeast-cells, as well as other organic material (see p. I 9I).

Such dust particles falling on the surface of the lichen, or washed down by rain, will be extremely useful, for they will furnish the lichen with useful food material.

It must not be supposed that lichens are unable to obtain mineral salts from the rocks on which they live. Some of them are specially expert in corroding the rock surface. The curious root-like fibres which one finds on the underside of a lichen are sheafs of fungus threads which are well able to absorb nourishment as well as to fix the lichen to its support.

One of the chalk lichens (Sarcogyne simplex) can eat its way downwards to a depth of some I $5 \mathrm{~mm}^{4}$ (a little over half an inch) in the solid chalk; others can penetrate to $6 \mathrm{~mm}$. depth in siliceous rocks (.234 inch). There are some authors who hold that lichens do actually corrode quartz, the hardest of all rocks. Rhizocarpon, which grows upon granite rock, does as a matter of fact penetrate into them. Its rhizoids dissolve the mica and force their way in between the quartz and orthoclase particles, and in this way it succeeds in disintegrating the rock. ${ }^{5}$

As some bacteria are able to produce "weathering" of certain rocks, it is not surprising that special rock lichens should be able to do so.

Yet the growth of lichens is very slow indeed, especially when one compares them even with mosses.

A leaf-lichen, Parmelia caperata, grew about $1.5 \mathrm{~cm}$. ( $\frac{3}{5}$ th of an inch) in seven and a half months. Another authority has calculated that .0610 cubic inch of the

* It has been possible to prove the existence of trees in the time when certain peat deposits were laid down by examining the peat with a microscope for blown pollen grains,-Frih. 


\section{Rock Lichens}

common Xanthoria parietina formed about $7,200,000$ cells in one month! On a wall which had only been built some thirty years, no less than thirty kinds of lichens were noticed, which of course means a considerable rapidity of development. ${ }^{6}$ It would be quite impossible for those which grow amongst mosses in forest soil (Peltigera canina) to keep their heads clear if they were not fairly quick in growth.

Lichens are not often eaten by the higher animals. The tripe-de-roche of the Canadian North is not an appetising food, and it seems to be only the reindeer that enjoys reindeer-moss, which is a lichen (Cladina rangiferina). Even specialists in omnivoracity like butterfly caterpillars are unable to eat certain lichens, which protect themselves by developing vulpin acid.?

The lichens or crottles of the Highlands are still used for dyeing Harris tweeds, but for various reasons it is advisable not to describe the usual processes too minutely.

So this interesting group is not without direct usefulness for mankind, whilst for the conquest of dry rocks, or lava-flows, they are the special pioneer form for higher associations.

1 Fritsch.

- Friederick.

2 British Museum Handbooks.

3 Aitken.

${ }^{5}$ Stahlecker, Bachmann. ${ }^{6}$ Fink. $\quad{ }^{7}$ Stahl. 


\section{CHAPTER VI}

\section{MOSSES AND PEAT}

THE mosses and liverworts form an isolated family utterly different both from the ferns and from the alga or fungi.

One would think that the distinct leaf, stem, and reddish or brown root fibres of a moss could be compared with the leaves, stems, and roots of the flowering plants, but that is not the case. These leaves and root fibres have been produced by the exigencies of the situation, and have no relationship whatever to the corresponding parts of a higher plant.

The whole theory of a moss is quite different and special. It begins life as a branched green threadlike "protonema," which closely resembles an alga, and on which the small buds appear which are to be its leafy stems. These last are intended to absorb the rain and dew, and especially the dust which falls upon them. One finds the neatest and most ingenious contrivances for catching, and especially for retaining this water.

Sometimes every leaf-tip is continued into a fine twisting hair ; sometimes the leaf itself resembles a deep spoon or a small soup-ladle, and yet the arrangement of the leaves is so contrived and the shape so modified that they assist one another, not only to keep the water when it falls but to preserve it when they dry up.

The leaves of the hair moss (Polytrichum, e.g.) not only individually roll or wrap themselves up lengthwise, but they also rise and press themselves against the stem. A dry blackish or brown withered tuft of any moss, 


\section{Mosses and Peat}

when soaked in water, will be at once refreshed and revived ; the leaves open out and stretch themselves, and the whole plant becomes fresh and vigorous.

A square yard of the feathery green Hypnum mosses will absorb in one minute fully one pound of water. But its capacity for drinking water is very small when compared with the regular peat moss (Sphagnum). A square yard of Sphagnum, after it has been saturated, will yield by careful drying 10,700 grs. of water. ${ }^{1}$

So that it is clearly impossible for mossy stones or moss-covered rocks to be worn away by rain. When the mossy cushion is saturated, the water simply flows over the top of it without ever reaching the stone. Such moss carpets would seem also to protect the rock against weathering by frost action, at least to some extent, for moss is a bad conductor of heat.

Moss cushions and moss carpets are very interesting, and have much more importance than one would suppose. In some of those found on dry walls, the little stems are closely packed and upright. When one looks down on them with a lens, one sees at once how perfect they are when considered as rain and dust traps. Their reddish brown rhizoids are closely entangled, and full of fine soil with insects' eggs, relicts of insect life, worms, \&c., interspersed in it. That soil is good and rich ; it is not peat, and so if the germinating rootlet of a grass manages to grow down to it through the moss cushion, it will branch luxuriantly and a vigorous little grass seedling will soon display its green rapidly growing leaves against the beautiful velvety background of the moss.

This colonisation happens more frequently with the other type of moss cushion in which the moss stems form a successive serics of curved feathery branched sprays thrown out from the centre and lying flat upon one another. These Hypnoid cushions are much larger 


\section{Mosses and Peat}

and may produce nearly an inch of soil. The younger fronds not only overlie and overshade the older branches, but there is a strong suspicion that they hasten their decay by feeding upon them! One sees plumes of rhizoids (i.e. root-fibres) fixed upon the withering older fronds of the same plant and apparently extracting from them any valuable material that yet exists. ${ }^{1}$

Fungus parasites sometimes occur on moss rhizoids, but it is uncertain if they possess a well-marked fungus assistant or mycorhiza such as one finds with higher plants. The liverworts (allied to the mosses) do sometimes possess one. ${ }^{2}$ But the moss family has carried this power of absorbing water to such a degree of perfection that it often becomes a nuisance to mankind.

One sees this in the "fog" of ordinary pasture land, which is a smothering moss development which interferes with the growth of grasses and other plants. Such fog appears when the land is so wet or has been so much grazed that the flowering plants are not growing rapidly enough to keep the moss in check. (One can almost always find a few mossy strands anywhere even in good pasture and particularly in autumn.) But the peat mosses of lowland swamps and of the moors of Britain and Ireland are even more serious evils, for they occupy, almost uselessly, a large extent of country.

Such feathery mosses as the Hypnums and Hylocomiums are apt to weave themselves about the stem bases of marsh plants and mud plants. They absorb and hold water strongly, but in such places, if the ground is always water-saturated, the peat moss, Sphagnum, will soon appear. It is of a pale whitish or yellowish green (often, however, pink-tinged at the tips). The stems are upright and branch at every fourth leaf, so

* A fungus, Mollisia Jungermanniæ, assists and depends upon Calypogeia. Marchantia, Preussia, and Fegatella also have a mycorhiza. 


\section{Mosses and Peat}

that its cushions are very close and crowded and soon tend to swell up into small dome-shaped or convex projections. Both leaf and stem are full of empty cells which act as water cisterns and possess fine spiral strengthening fibres to prevent collapse. The appearance of these cells reminds one of indiarubber tubing, strengthened by a spiral wire inside.

Suppose now that a wet marsh is beginning to be dotted about by separate Sphagnum plants. Each is a circular cushion convex upwards and always widening at the circumference. Every shower of rain saturates them; any surplus water simply collects under the cushions. In time the cushions begin to touch one another, but there will be some inequality of growth so that the surface is uneven with holes full of water between the bulging convex surfaces. The moss, however, still goes on growing upwards, and eventually forms a huge accumulation of peat, which may occupy the whole marsh. In the middle it will be on the whole higher, and it will slope as a very gently arched dome from the centre to every part of the circumference. This mass of peat is composed of the dead remains of the Sphagnum itself, and of all other plants which succeed in growing there; they do not decay, because the living crust of Sphagnum being saturated with water and very closely packed together, does not permit the free passage of oxygen to the dead vegetable matter below. Moreover, there are but few bacteria, for there are antiseptic substances in peat. Hence such peat mosses are extremely valuable from a historical point of view. One can not only distinguish the changes in vegetation that have occurred since the peat moss began to grow, but if there be bones of animals or prehistoric canoes and other implements, they are quite well preserved (see Chap. XX.). 


\section{Mosses and Peat}

But the natural history of the moss itself has many other interesting features.

Below there are the accumulated remains of possibly hundreds or thousands of years of Sphagnum-growth, whilst the living crust of mosses on the top is stili vigorous and active. Those moss plants may, for aught we know to the contrary, be the identical individuals which perhaps began to grow there at the close of the glacial period, and which have gone on developing at the top and dying off below ever since.

During extremely heavy and long continued rain the water penetrates through the living Sphagnum crust, and collects between it and the dead peat underneath. It sometimes happens that the skin of floating mosses bursts at the edges. Should the moss be above the level of the surrounding country, a deluge of peaty water may burst forth and overflow the neighbouring lowlands. Such bogslides or slippings are extremely dangerous, and several destructive cases have been recorded, especially from Ireland. One of the worst was that at Rathmore in 1896 , when two hundred acres of bog burst and covered some ten miles of country with black and liquid mud. It is said that nine people were suffocated. There was another case of the same sort on October II, I900, at Lisdoonvarna, when a house was thrown down and two people were killed. The reader may have noticed in January x 909 another bogslide at Kilmore in Galway. A small village was overwhelmed, and the peat rose to the very ridge-tiles. One woman was suffocated in her sleep.

But at some period or other in the history of a peat moss, the uppermost living Sphagnaceæ begin to feel the effects of drought. Even in very old bogs the surface seems to be usually uneven; there are the bulging little hillocks of squashy Sphagnum, with here 


\section{Mosses and Peat}

and there deep pools of liquid black mud at least four feet deep, into which one's foot is apt to slip. On the top of the hillocks the drying influence of the wind or of sunshine in a dry summer, hampers the growth of the Sphagnum, and perhaps a few plants of Polytrichum or an adventurous heather seedling succeed in establishing themselves. Now begins a struggle for water between the Sphagnum and the heather roots.

Should strong winds and a dry summer or two favour the growth of the latter, the roots will colonise the summit of the Sphagnum hillock and proceed to gradually kill out the moss all round them. The upper surfaces of all the hillocks may in that case become dry crumbly peat occupied by heather and masses of grey and white lichens with perhaps a few other plants. These heather plants are, however, separated by an irregular network of living moss, deep mud holes, or possibly irregular water-courses full of various sedges and marsh plants.

If the conditions are favourable, the whole surface of the moss will become dry dead peat, in which the heather, blaeberries, oxycoccus, \&c., are growing vigorously. As soon as that happens, if sheep and cattle are excluded, seedling Scotch firs and birches begin to overgrow the moss, and quite a forest might develop if the neighbouring villagers would leave it alone.

Such a Scotch fir forest was actually formed over most of the Scottish uplands (see p. 225).

But it is not always the heather that wins the day; should the outlet of the little streams which leave the moss be choked up, then the Sphagnum of a hillock would gradually grow up over the heather stems and suffocate it.

On flat places, as, e.g., where peat has been cut and 


\section{Mosses and Peat}

carried away, a cottongrass swamp may often develop. This plant (Eriophorum), with its exquisite silvery tassels of shining white down, must have been noticed by every one who has been on the Scotch or Yorkshire moors.

It has very tough, wiry, and indestructible leaf-bases or sheaths. As air can reach the roots by passing down between these sheaths, it is able to compete with the Sphagnum. What is known as a cottongrass moor is the field of battle between the two. The struggle may go on season after season, but if wet conditions prevail, the Sphagnum conquers, and if dry the heather will probably annex the cottongrass moor. ${ }^{3}$

The peat moss litter imparted from Holland seems to be the product of such cottongrass mosses. This is one of the few valuable products obtained from peat. Unfortunately it is unlikely to be used on a large scale, for manure made from peat moss litter is liable to contain the seeds of many dangerous weeds, and is also apt to produce a saturated water-logged soil.

The enormous areas occupied by heather moors and peat mosses both in Scotland and Ireland are a serious economic loss. Enterprising landlords have in former times reclaimed a very large number of acres.

The methods which were usually adopted in the south of Scotland about $1812-1825$ or 1830 were as follows :

Good drains were first cut to carry off the surplus water, and then the heather and other growing plants were cut over and burnt. Sand or clay or estuarine silt was then clistributed over the surface, and in most cases a large amount of lime was also laid down. Heavy manuring was resorted to, especially in the first few years.

The result of the labour and money spent upon reclamation at that period was entirely satisfactory, for 


\section{Mosses and Peat}

land before only worth Ios. per acre was changed into good farmlands worth $£ 5$ per acre. ${ }^{4}$ Strange to say, when one refers to Früh's splendid and recent monograph (1904) on the Swiss moorlands and peat mosses, ${ }^{3}$ one discovers there that what little is being done in scientific Switzerland seems to be by essentially the same methods as were employed by our forefathers in I 8 I 2 .

Burning, liming, and manuring are the usual methods ; but such artificials as Thomas slag, phosphates, or potash salts are also used. Dr. Früh himself says, "They show even to-day on the whole the same crops and the same simple culture as existed one or two hundred years ago." The usual crops are potatoes, kohlrabi, carrots, oats, rye, wheat (spelt), peas, beans, and rape.

In the North-Eastern United States, a kind of cranberry (Vaccinium macrocarpum) is said to be cultivated on moorlands. Certain lands in New Jersey are rented at from 8 to 13 dollars per acre for this unusual crop, which has also been tried in North Germany. According to Shaler, ${ }^{5}$ there are some 100,000 acres of suitable cranberry land in the United States.

So far as this country is concerned, one may perhaps say that all heather moorland up to a certain altitude (possibly two-thirds of the height of the highest hills in the neighbourhood) might be at once changed into forests by draining, planting with Scotch fir and other trees, and excluding sheep and deer. The author does not think that this is seriously denied by any scientific authority on such subjects.

It is sometimes questioned whether it will pay to undertake such reafforestation, but the real reason which prevents anything being done seems to be the existence of grouse, and the fact that the forests would not benefit the present owners of the moors, who would be dead before they paid for their plantation. 


\section{Mosses and Peat}

At present the city of Glasgow has made a profitable business of reclaiming peat mosses by utilising a conveniently placed moor for the deposit of city refuse.

All sorts of attempts have been and are still being carried on with a view to utilising directly the great masses of peat which are still "wastes" both in Scotland and Ireland. Sometimes fuel such as briquets of peat mixed with dross are manufactured. String, cloth, rugs, horse clothing, paper mats, and even cattle food have been made out of peat. The last is produced by shredding the peat and saturating it with molasses.

But there is a lamentable history of financial failures connected with such undertakings of which there have been a very large number.

The latest method (which is said to have proved a success in Sweden) consists in only partially drying the peat, and burning it on the spot. By this use of it as fuel, electricity is generated and is sold to neighbouring consumers.

But when there is less fear as to the security of commercial enterprises, and especially of landed property in Britain, there can be but little doubt that the simple and obvious course will be followed. Once again there will be a great Caledonian forest of Scotch fir, and even in Ireland it may be that there will be again great and valuable forests, providing employment for thousands of working men and solving many distressful problems.

When one reflects on the millions of money annually wasted in wildcat schemes, such as gold mines and the like in the most out of the way parts of the earth, it is strange to think that such large areas of Britain are still awaiting development.
1 Cserey.
2 Golenkin.
4 Singer.
${ }^{3}$ Frïh and Schroter.
5 Shaler. 


\section{CHAPTER VII}

\section{THE FERN ALLIANCE}

IN the last chapter we scarcely perhaps did justice to the extraordinary beauty of mosses when one has the good fortune to find them in a home that is really congenial.

There are such places in many warm but not quite tropical climates. In the Perie bush, near King William's Town in South Africa, when stumbling down beside some little burn or rivulet, every great boulder or small precipice or stone is covered by the most exquisite cushion of soft green, feathery branching moss fronds and liverworts.

Planted in it, as effectively as any gardener could have managed, were quantities of Streptocarpus. Most were in full flower; the gracefully curved stalk rose from the huge wrinkled leaf that hung down over the mosses. Above the little stream arched branches were crossing at every angle, and each of these was also entirely covered by the intricate greenery of mosses. Upon the branches were orchids and other parasites, but especially an abundance of ferns.

Indeed the place was almost a fern glade, with a moss background everywhere.

In other parts of tropical Africa, but also it is said in New Zealand and elsewhere, there exist warm, moist ravines, sheltered amongst the hills in which, in every direction, the eye sees nothing but luxuriant, finely divided fern-leaves springing from rough tree-fern stems 


\section{The Fern Alliance}

which are wound round with climbing Lygodium or festooned with beautiful mosses. There are tall treeferns 60 feet high or more, but on the ground there are other smaller ones and of the most varied kinds. The flowering plants seem to be very much in the background in such situations, for the shady, damp atmosphere is eminently suited to ferns and mosses.

Even in Britain one finds, here and there, deep valleys and ravines with the branches of tall trees hanging over the river, and which are enough to give a basis for fancies as to the coal-measure times.

The ground may be full of male and lady ferns quite as beautiful as anything in the tropics. On the larger branches there is the inevitable moss cushion with rows of polypodies whose graceful fronds hang over into the atmosphere, which is damp and humid on account of the river below them. In the very shadiest places between the boulders one may, even to-day, discover the filmy ferns, which are rare in Britain.

Plenty of creepers and especially ivy and honeysuckle grow in such places.

It is this sort of fern and moss glade in England, or the New Zealand and African tree-fern ravines, that inevitably recall themselves to one's mind when looking through a set of coal-measure fossils. The fern-like appearance of most of the specimens is quite unmistakable. But there must have been some very special characters in a forest of the Carboniferous period.

Many of the plants exactly resembled our small clubmosses, but they were tall trees 60 to 80 feet in height, with a branching that seems stiff, clumsy, and archaic.

The smaller fernlike plants flourished around their roots, but the soil was everywhere soft and slushy. In the Antarctic beech forests of South America one finds great accumulations of the sort of material from which 


\section{The Fern Alliance}

our coal may have been formed. It is not peat, nor liquid mud, nor leaf-mould, but a slush more or less resembling them.

Great thickets of reeds very like our common horsetails (Equisetum limosum), but also 60 to 80 feet high, would flourish along the banks of the sluggish rivers or fringe the great coal-measure lagoons.

The rootlets of these extinct Calamariæ can sometimes be traced in a distinct and definite layer closely resembling Equisetum deposits in a lowland bog.

Beside the pools of black water were marsilea-like, fern-like, and other herbaceous plants.

Gigantic, bony-plated, salamander-like animals from 6 to 8 feet long wallowed in those slimy waters, where also were plenty of the fishes on which they fed.

The atmosphere in these forests and marshes would be damp and still.

There was no lack of animal life, for things like earwigs lived upon the branches, and upon the ground were great millipedes, very like the huge forms which are common in the Madagascar jungle, and which roll up into a ball an inch or more in diameter when disturbed. We should also mention gigantic insects, such as the great maybugs, which were probably devoured by large dragon-flies, two feet across the wing, and very likely brilliantly coloured.

The really important part of those forests was the black slush or slime of the forest pools and slow rivers, for in them the bodies of the animals and of algæ, as well as other vegetable matter, turned to bituminous coal.

There is a graphic description by Stokes and Watson ${ }^{2}$ of the conditions in those days of certain flat, swampy levels between the higher ground and the sea. Here were groves of large trees which grew in brackish water, or in mud like that of a mangrove swamp. 


\section{The Fern Alliance}

The twigs, leaves, and fruits fell into the quiet pools and shallows, and were swallowed up and preserved in the salty or brackish mud. Rootlets of living plants wandered amongst and sometimes through these buried stems and fruits. Then the whole mass was submerged by an arm of the sea, and concretions of carbonate were formed out of the remains by the withdrawal of calcium and magnesium sulphates.

The rivers and currents in the estuary brought fragments of plants from the higher lands, which were laid down and pressed flat by the silt which accumulated above the older forest, and these water-borne twigs now occur in the shales formed by the silt.

One can see to-day in the Solway silt, round, blackish concretions which are due to peat fragments of a much older date that have drifted in the water and are now decaying into a carbonaceous mass.

Many petroleum deposits seem to be really estuarine or lake-muds similarly submerged after their formation, for salts and marine fishes or shells occur in them. The oil was probably formed originally by minute algæ or animalculæe. In order to test this question a quantity of a common pond alga (Microcystis flos-aquæ) was chemically tested and petroleum was really obtained from it.

As regards many details of life in the coal-measure forests we are very well informed, thanks to the skill and ingenuity of geological botanists.

It is known, for instance, that a root fungus (Mycorhiza) assisted some of the coal-measure trees to do their work. $^{3}$

Some of the fern-like plants were probably, even in those days, attacked by rust fungi. ${ }^{4}$ Dr. Scott has figured germinating spores of some of the coal-measure plants. Mr. Gordon has even figured the prothallium 


\section{The Fern Alliance}

of a Selaginella-like club-moss (Lepidodendron Veltheimianum), and one can see the splitting of the sporecoat. $^{5}$

That such rare and delicate forms of vegetable life as fungi, spore-tubes, and the prothallia, which grew in Palæozoic times, have come down to us is sufficiently marvellous, yet gives a very deceptive impression of our knowledge of the Carboniferous period.

It is not certain whether the atmosphere was cold or a damp, steamy heat. Professor Henslow has tried to show that the climate was dry and not damp, but this theory has not been accepted by most geologists and botanists. ${ }^{6} \quad$ Mosses do not seem to have been nearly as abundant as one would have thought likely, but the peatmud-like character of what is now coal is like the peaty humus of the forests of Valdivia or Punta Arenas in Chile, of the summit of Ruwenzori, or even of the oak and birch clumps at the edge of a peat-moss in Scotland.

It was, in the author's opinion, a damp, still, and steamy atmosphere certainly, but not necessarily a very hot or even a subtropical climate.

But the real difficulties and dangers of this chapter begin when one tries to give even a sketchy impression of the great and important discoveries which have been made by many English botanists, who have laboriously examined the actual plants which lived in the forests.

So far we have been, intentionally, as vague as possible about them.

Von Wettstein, in a recent publication, ${ }^{7}$ sketches in a yery interesting way the general course of development of the great groups of plants.

The algæ were water-plants. The mosses begin life as a green thread-like mass called the protonema, which is exactly like an alga and also lives in water. Yet their stems are in most cases formed in air. 


\section{The Fern Alliance}

One period of the life of a fern is that known as the prothallium. In some ferns (Schizæa bifida and Trichomanes) the prothallium is very like an alga and probably lives in water, but in most it is a little flat green and fleshy body which flourishes on continually damp soil. ${ }^{8}$

So Von Wettstein gives a neat little figure showing the way in which land plants developed out of what was once a purely water-flora.

This point has been elaborated in an important work by Professor Bower. ${ }^{9}$

The algæ and fungi are essentially water-plants, and the process of fertilisation is performed in water. The little free-swimming sperm cell or male cell swims to the egg cell and effects fertilisation under water. Then the egg cell begins to develop. In many algæ and fungi it does not at once form a new alga, but grows, dividing many times, so as to form a number of cells. Some of these are the spores which will produce the new alga or fungus, but others may never become spores at all. Some cells will form a sort of shell or envelope to hold the spores, and others may become creeping filaments which attack the branches of the parent alga and absorb food material from them (e.g. Florideæ).

This stage in the life-history from the egg to the spore may be called the spore-plant. This spore grows into what we call the alga, which produces the sperm and egg cells. In mosses the sperm cell also reaches the egg cell by swimming, for during the life of most mosses (especially in February to March in England), moss-tufts are often covered with rain water. The egg cell in mosses, when fertilised, grows and forms the elegant little stalk which ends above in a small capsule, from which the spores are distributed. The base of the stalk extracts food material from the mother moss, and 


\section{The Fern Alliance}

there are green cells and stomata on the capsule itself. The spore-plant has therefore an absorbing base, a stalk or stem, and a green capsule with many spores.

But in the case of the fern alliance, the spore-plant is what we know as the fern, which of course has a well-formed stem, roots, leaves, as well as the spores, which are produced upon the leaves. The spore, which germinates on moist or wet ground, forms a tiny little half-fleshy prothallium about a quarter of an inch long, and it is this that forms spermatozoids and egg cells.

Professor Bower considers that both ferns and flowering plants have developed from a spore-plant something like that of a moss or liverwort. In very ancient times, the spore-plant developed leaves for the purpose of carrying spores. Then many of these leaves took on the function of foliage leaves and ceased to bear spores. Typical roots developed from the base of such a spore-plant, and it also formed internodes between the leaf bases just as and when required.*

In the flowering plants the sperm cell (part of the pollen grain) is carried either by wind, insects, or some other means to another flower; but when the pollentube begins to grow down into the style so as to reach the egg cell, there are certain faint indications which seem to remind us that at some very ancient and distant period it was a free-swimming, spirally curved sperm cell, perhaps like that of a fern.

There are a few cell divisions during the development of both the pollen grain and egg cell which seem to correspond to the prothallium.

* There are the three theories. (I) The leaf preceded the stem. (2) Leaf and stem appeared together. (3) The stem preceded the leaf. The reader must be referred to the original for further details as to Celakovsky's Sprossglied theory, \&c. When put in brief the discussion sounds as futile as, Which came first, the hen or the egg? 


\section{The Fern Alliance}

We have not yet discovered the ancestor of the flowering plants, so that it is impossible to prove or disprove any of these ingenious speculations.

Both the great groups of flowering plants (Monocotyledons and Dicotyledons) suddenly appear about the beginning of the Cretaceous period, and not as single individuals either, but in battalions, with many of our natural orders and not a few present-day genera.

On the other hand we now know, thanks to the brilliant researches of Professor Oliver and Dr. Scott, that seed-plants not only existed but were common in coal-measure times. They have proved that a certain fossil (Lagenostoma Lomaxi) is a true seed with a husk or cupule. Its stems are fossils known as Lyginodendron, and its foliage seems to be another fossil called Neuropteris, which had hitherto been supposed to be a fern. ${ }^{10}$

Some of these coal-measure seeds are more or less succulent (Trigonocarpus), and it would be interesting to know what sort of animal lived on them. Could they be distributed by fishes? This is not impossible, for, as Spruce points out in a recently published book, shoals of fish lie in wait for the fruits of some of the trees in the Amazon valley.

Neither birds nor mammals, and not even Pterodactyls, existed in those days.

It has been found possible to trace, more or less accurately, the pedigree of some of our still living coniferous trees. They are descended from the fossil Cordaites which have been connected with the seedferns or Cycadofilices of the coal-measures. These last spring from a very primitive fern-stock.

From these last-mentioned primitive ferns (or Primofilices of Arber) our modern ferns have been derived, but did not diverge from them before later Carboniferous days. ${ }^{11}$ 


\section{The Fern Alliance}

But the reader must be referred especially to the "Annals of Botany," where the discoveries of Dr. Scott, Professor Oliver, Mr. Arber, and many others are given in the original.

In the comparatively quite modern Jurassic period, which has been so thoroughly studied by Seward and others, the most interesting point is the extraordinary uniformity of the flora wherever its remains have been discovered. Plants of the very far South, such as those described from Louis-Philippe Land, $63^{\circ}$ I $5^{\prime}$ S., from Greenland, from temperate Europe, and from the tropics, seem to have a remarkable similarity in appearance, which shows either that the climates of the world or that its vegetation had not specialised or become so diversified as they are in our own days. ${ }^{12}$

The ferns of to-day are by no means confined altogether to still, moist atmospheres, though it is in such a climate that they seem to luxuriate.

Our common bracken is one of the most cosmopolitan of plants, found almost all over the world, but usually at least on poor soil. In the Scottish lowlands and highlands it is a dangerous pest, for it spreads over sheep pastures and heather moors. Some practical method of exterminating it has yet to be discovered.

If for two or three years it is mown three or four times over in a season it is said to vanish, but that is far too expensive a process.

Sheep will not eat it, nor is there even a beetle or insect which seems able to browse upon it. But it is said that, in Japan, the bracken is really eaten and enjoyed by the labouring classes. If it were possible to recommend its use as food for man the question would indeed be solved, but the author does not wish to be guilty of any person's death or even of "un mauvais digestion," so he must admit that when he 


\section{The Fern Alliance}

himself tried to eat the young shoots of bracken, which were served as asparagus, the taste was so unutterably horrible that he was daunted by the task.

What is said to be the right method of cooking it consists in soaking the young shoots for twenty-four hours in salt water and then stewing with butter like asparagus. If the reader cares to do this it will be upon his own responsibility, for the author will not be answerable for any results.
1 Potonié.
4 Dietel.
2 Stokes and Watson.
3 Weiss.
7 Von Wettstein.
5 Gordon.
8 Thomas.
6 Henslow.
10 Scott, Oliver, Arber.
11 Arber.
- Bower.
12 Seward. 


\section{CHAPTER VIII}

\section{ALPINE AND ARCTIC FLORAS}

ON the summit of a highland mountain, even on moorland hills of no great altitude, there is often a sudden change in the plant world.

After the exhausted botanist has trudged or bogtrotted through miles of peat-moors and uninterestingly monotonous moorlands, the flora of the weather-beaten summit itself comes as a refreshing change.

Here there are blackened or mouse-coloured and grey rocks projecting as angular fragments amidst loose discoloured pebbles. Their stone surfaces are entirely covered or nearly so by a rich though intricate and difficult series of ugly little lichen-crusts. But all the rocks and stones are framed by a thin nearly continuous moss carpet which stretches over the poor rocky soil, and, so to speak, frames and borders the bolder frost-shattered projections. Here and there, dotted about in this thin mossy covering, one finds a scanty band of the hardiest forerunners amongst the flowering plants. The "alpines" are the most interesting, for many of them are glacial "relicts" which have been driven to these inaccessible summits by the invading hordes of ordinary lowland plants.

Such summit floras are of extraordinary interest, for they give many hints as to the first stages in the colonisation of our country after the disappearance of the snowfields and glaciers of the great Ice Age.

One interesting point about them is that, even when miles away, one can distinguish the "summits" in our sense from the lower and upland hills. The outlines of the ridges and higher ground is generally composed 


\section{Alpine and Arctic Floras}

of smooth swelling curves rising one above another and easily sketched in by long sweeps of the pencil. But, even at a distance, the jagged, saw-like edges or irregular rocky bosses of the summit are quite distinct, and can only be drawn with some trouble, for they require many short, straight, or irregular lines.

The reason for this difference depends upon the plant-covering. In the lower grounds, minor irregularities have all been smoothed over by their continuous covering of vegetation. The outline of a peat-moss or of grass-land, even of a properly grown forest or woodland, is a continuous curve. Where straight broken lines appear, they are due either to man's agency or to the fact that some steep precipitous crags or ravines have not yet been occupied by the plant world.

On the summits the flowering plants are not continuous but dotted about or isolated, forming what is known as an "open" flora. Yet on such a summit the flora is trying to close itself up ; attempts are being made to cover the whole surface by one continuous vegetation. But there are several competitors.

One finds, for instance, many blaeberries, here and there grasses (such as sheep's fescue and Aira flexuosa, perhaps Nardus), and certain rushes (J. squarrosus); sedges may be scattered here and there (Scirpus spp., and perhaps alpine Carices), and, which is of geological interest, our miserable little Lycopodiums and the hardfern are common enough.

On the very highest of our Scotch, Welsh, and English mountains one finds in such places the regular alpines (Lychnis alpina, Alchemilla alpina, Armeria, Saxifrages, and the like, see below), but those we have mentioned above are common, and also occur at very great altitudes and in high northern latitudes.

A blaeberry in such places has rooted itself in some 90 


\section{Alpine and Arctic Floras}

crack or cranny of the rock, which has been filled up by blown dust and moss-earth, \&c. Its pink shoots will be found growing through the moss-cushion, and obviously it is living on the soil formed by many ages of lichen and moss-growth, and is also attacking the rock or clay below. Yet the moss surrounds it, and a struggle is going on between the two of them. If the rainfall is heavy and frequent the moss will conquer, and a Sphagnum bog will cover the ground. Should the blaeberry manage to hold its own, aided by dry spells and plenty of wind, it will form a sort of blaeberry moor, and eventually a heather moor growing on a dryish peaty soil, which, however, has still a coating of mosses and lichens.

In another part of the summit one may find such sedges as the deer's hair Scirpus. That part might turn into a cotton-grass moor, which may become a continuous battlefield between the silvery cotton-grass and the Sphagnum, lasting perhaps for hundreds of years, for some cotton-grass peats are many feet in thickness.

But on very dry or steep slopes or, for example, on a limestone ridge, the mountain grasses manage to conquer the moss altogether, and the summit might become an alpine meadow or, in our own country, sheep pastures, that is, grass heaths (chiefly Nardus mixed with rushes and sedges), or the beautiful, green, closely nibbled turf of mountain limestone or basalt.

When one lifts one's eyes from the battleground on the summit and surveys the surrounding country, one sees miles of peat-moss, heather moor, cotton-grass swamp, or grass heaths.*

It was by this sort of proceeding that Britain was

* The reader will hardly realise the enormous area occupied by such vegetation unless he consults the botanical survey maps of Smith, Lewis, and others (see p. 224), or, which is preferable, visits such hills himself. 


\section{Alpine and Arctic Floras}

colonised again after the Ice Age disappeared. First the seashore, then the lowland hills and valleys, and finally the uplands were occupied, until it is only on such summits that one finds any hints as to the way in which it was done.

In the arctic regions the tundra, which occupies so much of Siberia and of Russia and Lapland, is also a moss-covered, more or less peaty country, where the flowering plants are scattered about and isolated, forming an open flora. The conditions of life for these miserable stunted starvelings are extremely severe, and not at all easy to understand.

A pathetic account by Middendorf is cited in Schimper's classical work on plant geography. ${ }^{1}$ "On the I $4^{\text {th }}$ April I found myself on the Yenisei near Dúdino. ... The landscape still lay buried in the deepest winter rest, and the clear shining of the sun, although it hardly sank below the horizon, could not even during the warmest hour of the day raise the temperature above $16^{\circ}$ to $20^{\circ} \mathrm{R}$. $\left(20^{\circ}\right.$ to $25^{\circ} \mathrm{C}$.) of frost. Before and after twelve o'clock, the thermometer regularly stayed at from $-23^{\circ}$ to $-30^{\circ} \mathrm{R}$. $\left(-29^{\circ}\right.$ to $-38^{\circ} \mathrm{C}$. $)$. I went out to observe the scene. Where the snow had sunk or been blown off by the wind, the projecting branches of willows had broken through and crunched like wax under my snow-shoes. They were frozen stiff, and one could see the icy sap where they broke off. Suddenly I stopped in amazement, for, peering out of the snow, but sometimes not more than $I_{\frac{1}{2}}$ inch above its surface, were willow catkins, perfectly formed and of a shining, silvery white. The very twigs which produced them were in their lower part frozen hard at only 2 inches deep in the snow, and of course the stems, branches, and roots, deeply buried below the snow, were even more thoroughly frozen up." 


\section{Alpine and Arctic Floras}

This will explain what is really the chief difficulty of the arctic, and in a less degree of our highland and other alpine forms. Being in sunshine they must, of course, respond to it and set about the work of assimilation. But where is the water to come from? Roots, stems, and branches are frozen hard, and no water can reach them.

So surrounded by leagues of frozen water, these wretched plants are actually perishing of thirst.

The cold itself is by no means so dangerous an evil as this, for, as we have seen, seeds when dry can support an almost unimaginable number of degrees below zero. So arctic plants manage somehow to keep down the loss of water by transpiration. They require but very small amounts of water even in relatively high temperatures, as has been shown by actual measurement. ${ }^{2}$

Perhaps one should mention here a strange fact that has been recently commented on by several botanical authorities. In some respects there is a wonderful resemblance between all "open" floras wherever they may occur. Such apparently different associations as these arctic plants, desert plants, others which live above the clouds in the dry cold regions of Tibet and the Andes, marine plants, not only those of salt marshes but of sandy sea-shores, rock "floors" and the like, often show a peculiar and interesting resemblance.

The explanation seems to lie in the fact that all such floras must do with as little water as possible. In the deserts and above the clouds, simply because there is extremely little to get; in frozen ground it is not available, and in salt soil it is of so poisonous a character that they reduce their demand for water to a minimum.

One of the most salient characters of alpine plants is the dwarf, stunted character of most of them. One need only refer to the tiny willows, a few inches high, which represent the genus Salix at great altitudes. 


\section{Alpine and Arctic Floras}

Although Salix herbacea and lapponum are minute woody little plants, they are obviously the close allies of the tall shrubs and pine trees of lowland riversides.

But the root system of many of these tiny mountain plants is often very well developed.

In a collection of plants made by Dr. Thorold at high altitudes in Tibet (between Niti and Mansarowar), there was not a single plant which had a stem more than I foot in height. A large number were less than I inch, and very few more than 3 inches high. Five of these plants were found at over 18,000 feet altitude, and one of them, the tiny Saussurea tridactyla, was found at I9,000 feet, and holds apparently the record for alpine climbers in the plant world. ${ }^{3}$ Dr. Radde, ${ }^{4}$ who thoroughly explored the Caucasus, also gives many examples. He found, e.g., Draba rigida, one-sixth to one-eighth of an inch, at I I, ooo feet, Sedum tenellum three-quarters of an inch; our eyebright or a form of it (Euphrasia officinalis), only one-half to threequarters of an inch, and yet all these were perfect plants, quite healthy, and able to flower and set seed! Draba and Alsine, only $I$ inch in height, had a fibrous network of roots some 3 to 5 inches in diameter.

When one searches for this kind of starveling dwarf in Britain, one may occasionally find them. Thus, e.g., near Sligo Bay, in a dry sandy soil, the author found eight or nine different plants about I inch in height, and with fine root systems. One also discovers them on dry rocks near the seashore.

The common juniper is a good case in point. In lowland districts this is a large shrub or small tree, which is occasionally 30 feet high. But in the mountains it becomes a dwarf form (Juniperus nana), which is seldom I foot high.

If one cultivates Juniperus nana in the lowlands, as 


\section{Alpine and Arctic Floras}

has been done both in the Berlin and in the Zurich botanical gardens, it changes into Juniperus communis. This has been tried both with seeds and by transplanting a mature specimen. ${ }^{5}$

The distribution of Juniperus nana is very interesting. It occurs in the Scotch highlands, Wales, and Westmorland, to 2700 feet altitude. It is also found in the Alps and Caucasus, to 3575 metres (I I 600 feet) altitude in the Himalayas, and it is also widely scattered over the arctic regions both of America, Europe, and Asia.

Its growth is extraordinarily slow. An ancient plant I03 years old was only $48 \mathrm{~mm}$. in diameter (I.I8II inch) and increased in thickness by only .9 $\mathrm{mm}$. per annum (.035633 inch per annum).

This dwarf, stunted habit of many alpine and arctic plants may be quite simply explained by the fact that they have a very short season to grow in, and therefore have neither time nor (at least in Tibet and Siberia) water enough to become of a respectable size.

Some of our far too hardy and adaptable weeds seem to thrive both at great altitudes in the Caucasus or Tibet, and in the arctic regions, as the following short list clearly proves:-

\begin{tabular}{|c|c|c|c|c|}
\hline & Caucasus. & Tibet. & $\begin{array}{l}\text { Lapland } \\
\text { or } \\
\text { Siberia.* }\end{array}$ & Perthshire. $\dagger$ \\
\hline Ranunculus acris (buttercup) & - & + & + & 3980 feet \\
\hline Taraxacum officinale (dandelion). & $t$ & + & + & 3900 \\
\hline Festuca ovina (sheep's fescue) & + & + & + & at all levels \\
\hline Capsella bursapastoris (shepherd's & & & & \\
\hline purse) & I-2 inches & - & + & I750 feet \\
\hline Euphrasia officinalis (eyebright) & + & - & + & 3500 \\
\hline Poa annua . & + & - & + & 3980, \\
\hline
\end{tabular}

But in Switzerland, or even in our own mountains, * Sewell. ${ }^{6}$ $\dagger$ White。 


\section{Alpine and Arctic Floras}

the conditions are very often quite different from the rarefied air and intense cold of the Himalayas, or from the dreary tundra solitudes of the frozen north.

One finds little ravines full of moisture and rock ledges kept continually fresh by the water which trickles over them. The plants which grow there have a month or two at least of brilliant sunshine, and are always refreshed by dew at night even in the driest weather.

Such saxifrages, sedums, gentians, campanulas, and the like are the favourite "alpines" of the gardener, and they exercise a strange domination over those who have once taken any interest in them. They are usually small, neat, and compact, but are remarkable especially for their rich deep colours and relatively very large flowers.

But in an alpine garden and carefully looked after these mountaineers are neither so gorgeous nor so rich as they are on their native rocks and ledges.

There one finds the deep blue of the gentians, as well as crimson, rich reds, purple, gold-yellow, and pure white scattered over the short close vegetation in lavish profusion.

The experiment of transplanting numbers of these alpines has often been carried out, and it is always found that the colours fade and are by no means so gorgeous in the lowlands. This may be because they miss the sunshine of their mountain homes, or because life is too easy for them in a richly cultivated soil and equable climate. But the colour of flowers is a question in itself (see p. III).

There are many interesting questions connected with the origin of the alpine flora.

It is only of recent years that botanists have dared to explain the distribution of species by assuming the formation of new species in special places. 


\section{Alpine and Arctic Floras}

Now, in those splendid monographs inspired and edited by Professor Engler of Berlin, one often finds very interesting studies upon the travels and changes of special forms.

There was a circumpolar or rather North Polar flora in very ancient times. When during the great Ice Age this arctic flora advanced southwards and spread over most of middle Europe, it was invading a region already occupied. The plants of the older geological period seem to have been very much the same everywhere, from Spain by the Alps and Asia Minor to the Caucasus, and even to Japan.

The different mountain groups were isolated by this invasion, and one finds little sets of alpine species belonging to each group.

So in, for instance, the Balkans, there are four different kinds of alpine flowers. There are both stranded relicts of the circumpolar flora, left in the hills when the ice retreated, and also special endemic species which have formed themselves in these mountains only. Besides these some of the alpines seem to be descendants of plants of the steppes or dry grass plains of South Russia, and which have invaded the mountains. Another group consists of Mediterranean plants which also have ascended and settled themselves in the hills. ${ }^{8}$

The history of the woodrushes or Luzulas has been carefully worked out by the best living authority. ${ }^{9}$ Round the North Pole one species, Luzula spicata, is found in northerly latitudes almost everywhere. Another species, L. racemosa, derived from the northern group, extends by the Rocky Mountains to Mexico and has evolved into several species in the Andes. Luzulas have also reached the Himalayas. Even in the Abyssinian highlands there is L. abyssinica, and so far south as Kilimanjaro there are two peculiar species which 


\section{Alpine and Arctic Floras}

seem to be descended either from L. abyssinica or its parent form.

It is exceedingly hard to understand how the seeds of these plants skipped the gaps between the mountains of Europe to Abyssinia, then to Ruwenzori, and thence to Mt. Kilimanjaro.

Could a gale of wind blow seeds over such intervals? On the whole it seems more probable that birds who range over enormous distances in their annual migration must have given Luzula the opportunity of spreading from the North of Europe to far south of the Equator.

1 Schimper.

4 Radde.

${ }^{7}$ Buchanan White.
${ }^{2}$ Wulff, Tansley.

5 Kirchner.

${ }^{8}$ Adamovic.
3 Thorold, Hemsley.

${ }^{6}$ Sewell.

9 Engler. 


\section{CHAPTER IX}

\section{THE ANTARCTIC}

THE idea of an Antarctic flora, that is, of a series of plants which occur in the southerly ends of all the Continents, from New Zealand to South America, is by no means novel.

The great classical work of Hooker ${ }^{1}$ deals in great detail with these interesting forms, and it was published a very long time ago. But during the last few years there have been many expeditions towards the Southern Pole, of which the English and Scotch were perhaps the most important of all. But it is unfortunately true that the results of all this modern work, so far as flowers are interested, have not yet been explained in such a way that one could take refuge behind some great authority and quote his conclusions. Unfortunately Graham Island and the South Shetlands, which are quite close to the Antarctic, only possess one flowering plant, which is a grass.

Quite a large number of algæ, lichen, and mosses occur in the Antarctic regions. There are many algæ which are found both in the Antarctic and also in the Arctic regions, so that they seem to have crossed in some way the whole of the tropical and subtropical ocean.

Certain lichens also occur in the Arctic, in the Alps, and other mountains, and again in the Antarctic, without being found anywhere in the lowland country between them. This fact can only be explained on the theory that their minute dust-like spores are easily blown by the wind.

Those Antarctic mosses which were collected by Hooker, Borchgrevink, and Rudmose Brown have re- 


\section{The Antarctic}

cently been examined by M. Chardot. ${ }^{2}$ Twelve out of the forty-six species are cosmopolitan plants, but some of them are again allied to north temperate or arctic mosses.

But it is certain flowering plants of South America and New Zealand that have raised the most intricate and difficult questions.

The general plant world of South America is quite different from that of Australia and New Zealand. It is supposed to be descended from a very ancient flora which inhabited Brazil and Guiana. There are also descendants of Californian plants which came into South America by way of the Andes.

But in Southern Chile and Fuegia there are quite a large number which are obviously allied to Ausiralasian or especially New Zealand species.

The resemblances are far too many to be purely accidental, for one finds, for instance, woods in which the characteristic and master-plants are beeches which belong to the characteristic type of New Zealand, not to the northern type of beech.

One little mountain plant, Azorella, is specially interesting. It is found in many of the dry cold mountain deserts of the Andes of Northern Chile and North Argentina at 4500 to 5500 metres ( $\mathrm{I} 7,000$ to $2 \mathrm{I}, 000$ feet) altitude, where it is the characteristic plant of a special association. $^{3}$

Ázorella madreporica has an extraordinary appearance, looking very much like a small hummock of the coral from which it takes its name. Its little closely packed twigs form so hard and solid a mass that if one fires a revolver at them the ball glances off, being quite unable to penetrate it. Its compressed crowded growth is due to the many short hard twigs which are packed together by the dead leaves and dust between them. ${ }^{4}$

Such a habit is very characteristic of New Zealand alpine plants, and is a very important help to the plant 


\section{The Antarctic}

in keeping itself alive in the dry exposed plateaus and rocky hills where it grows.

Another extraordinary fact about Azorella and similar high Andine plants is also recorded by Dr. Reiche. On Ioth March I899, at I P.M., the air temperature was $16^{\circ} \mathrm{C}$. When the bulb of the thermometer was sunk in the sandy soil it recorded $38^{\circ} \mathrm{C}$. But in a very thick clump of Azorella, the temperature was only $2 \mathrm{I}^{\circ} \mathrm{C}$. At six in the morning of the next day both the temperatures of the air and sand were $3^{\circ} \mathrm{C}$., whilst that of the Azorella was $5^{\circ} \mathrm{C}$. So that in the cold morning it was three degrees warmer, and in hot sunshine seventeen degrees cooler than the sand wherein it grew. One can hardly suppose that a plant with such complex adaptations to life in the Andes, and forming characteristic associations, just happened to get to South America and establish itself there by a lucky chance.

There are three ways in which one might possibly explain the relationship of the New Zealand and Chilian floras. According to one theory, both these places as well as South Africa are Continent ends. Some very ancient set of plants once extended all over the world, it has been invaded and dispossessed of its ground by other and new plant-cohorts everywhere except in the ends of South America, South Africa, and New Zealand. These would be refuges where the older types have succeeded in keeping themselves alive.

One might compare the process to the survival of bushmen in the Kalahari desert in South Africa and of the recently exterminated aborigines of Tasmania. It has not been clearly shown that the Tasmanian aborigines were allied to the bushmen, but supposing this were true it would mean that this low type of humanity once extended all round the Indian Ocean from the Cape of Good Hope by India and Malaya to Australia and Van Diemen's Land. 


\section{The Antarctic}

Certain of the New Zealand and South American plants could be reasonably accounted for in this way. This is especially true of the old world conifers such as the genus Araucaria (see p. 28I).

But for most of these antarctics there is not the smallest evidence to show either that they are in any way specially ancient types or that they ever lived farther north than their present habitat.

One could bring any plant to any position on the earth's surface by such imaginary journeyings as would be involved on such a hypothesis as this. Indeed the necessary route for the Chilian would be right up South and North America across Behring's Straits to its original home, and for the New Zealand cousin by Australia and probably Borneo to Japan or somewhere in Asia. On the whole this seems a very unlikely explanation except for the archaic and antiquated conifers or some few of the most primitive and least evolved flowering plants.

On the second theory, one would explain the similarities by supposing that the seeds have been carried by some means or other across the Pacific Ocean. For the distribution of seeds and spores, one might almost say that everything which moves upon the surface of the earth is sometimes utilised to convey the germs of a new vegetation. Icebergs, gales of wind, ocean currents, and migrating birds seem the most probable of the many possible transporters of living seeds. At present, icebergs or drifting ice sometimes reaches $50^{\circ}$ South latitude, which is not very far from the Australian coast. ${ }^{5}$ Off the western coast of Fuegia the wind is violent enough to do as much conveyance of seeds as could reasonably be expected of gales anywhere in the world, and there is a continual succession of westerly storms blowing right round the South Pole at about $50^{\circ}$ South latitude. So that seeds 


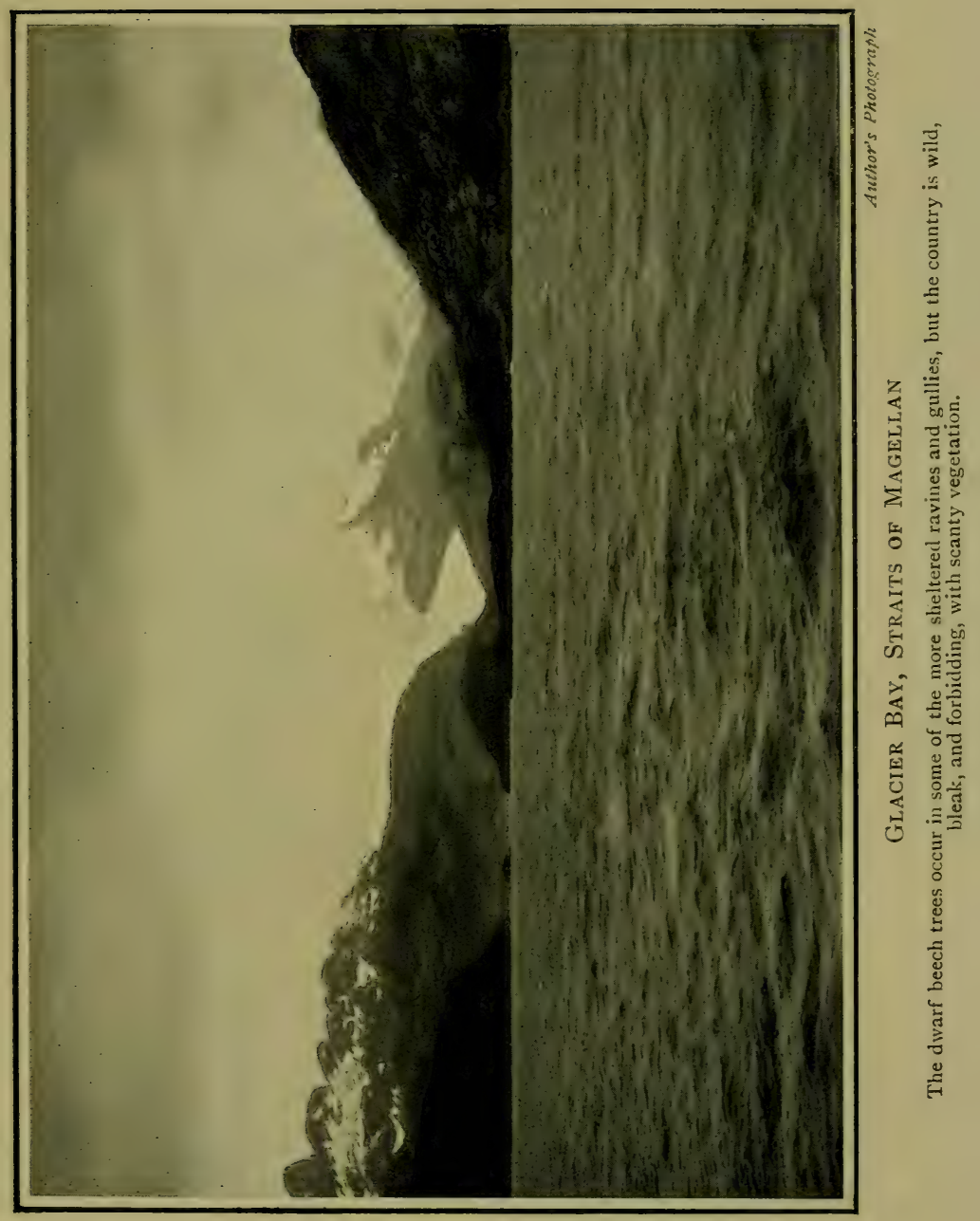





\section{The Antarctic}

might be wafted from Fuegia to New Zealand and thence back again to Fuegia if wind is ever capable of blowing seeds over such enormous distances as these.

The far-ranging albatross has been actually suggested to explain the distribution of Gentiana prostrata, and certainly if one is obliged to trust to such forms of transports, the mud on the plumage or feet of birds is by far the most probable explanation.

On the Snares islands, Mr. Cockayne ${ }^{6}$ seems to think that the winds, penguins, and sea-lions have greatly influenced the distribution of the flora, but he refers rather to the destructive effect of the wallowing of the sea-lions, or the violent gales which only the tussock grass can withstand.

Unfortunately for this theory there are several awkward facts connected with the plants in question. Compositæ, as we all know, are mostly carried by wind, and most of them possess the beautiful parachute-like crown of hairs which is specially designed for this purpose. But if so, why should six of the composites in this particular series be entirely without wind-hairs? These, in not possessing a pappus at all, are unusual exceptions to the general rule in that family! The mast of the Antarctic beech has wings, but the flying arrangement is small and strikes one as totally incapable of carrying its nuts over the Pacific Ocean.

Fortunately the third theory has much to recommend it, and would unquestionably explain all the facts in a satisfactory way.

Grahamland is connected with Patagonia by a submarine ridge which forms a great arch extending between Cape Horn and the South Shetland islands. The tertiary mountain chain of the Andes seems also to reappear in Grahamland. Indeed an elevation of only Ioo fathoms would unite all the islands off the west 


\section{The Antarctic}

coast of South America and form a continuous "solid" continent extending beyond Cape Horn.?

It might have been, as $\mathrm{Mr}$. Hedley suggests, a variable sort of connection sometimes dissolving into an archipelago of islands but provicling at possibly different periods of time island stepping-stones between Cape Horn, the Antarctic Continent, and New Zealand.

Some authors seem to have no hesitation in summoning a continent from the vasty deep simply in order to convey a beetle or a snail from one island to another, but it seems allowable in this case.

If such a connection once existed, that is, between Cape Horn and the Antarctic Continent, the whole circulation of the ocean currents in the far south would be altered. One would expect a current of warm water to travel south along the west coast of South America; such a warm-water stream would, and as happens in the corresponding latitudes of Norway and British Columbia, enormously improve the climate of King Edward VII. and Alexandra lands. They might then have been as genial places as Ushiuaia in Fuegia or Bergen and Hammerfest, and so could have supported such hardy plants and animals as now exist in Western Fuegia. From the Antarctic they might be carried northward to New Zealand.

As we have seen, there is some geological possibility for this connection. Certain animals, a peculiar horned turtle, and some peculiar marsupials are only known in South America and Australia, and such a connection has been suggested for their convenience.

It is not, however, essential for the plants that there should have been more than a chain of island steppingstones.

It may be interesting to give a list of the most important of them, so that the reader may appreciate the evidences involved. 


\section{The Antarctic}

\section{Genera of Plants found in both South America and New Zealand or Australia}

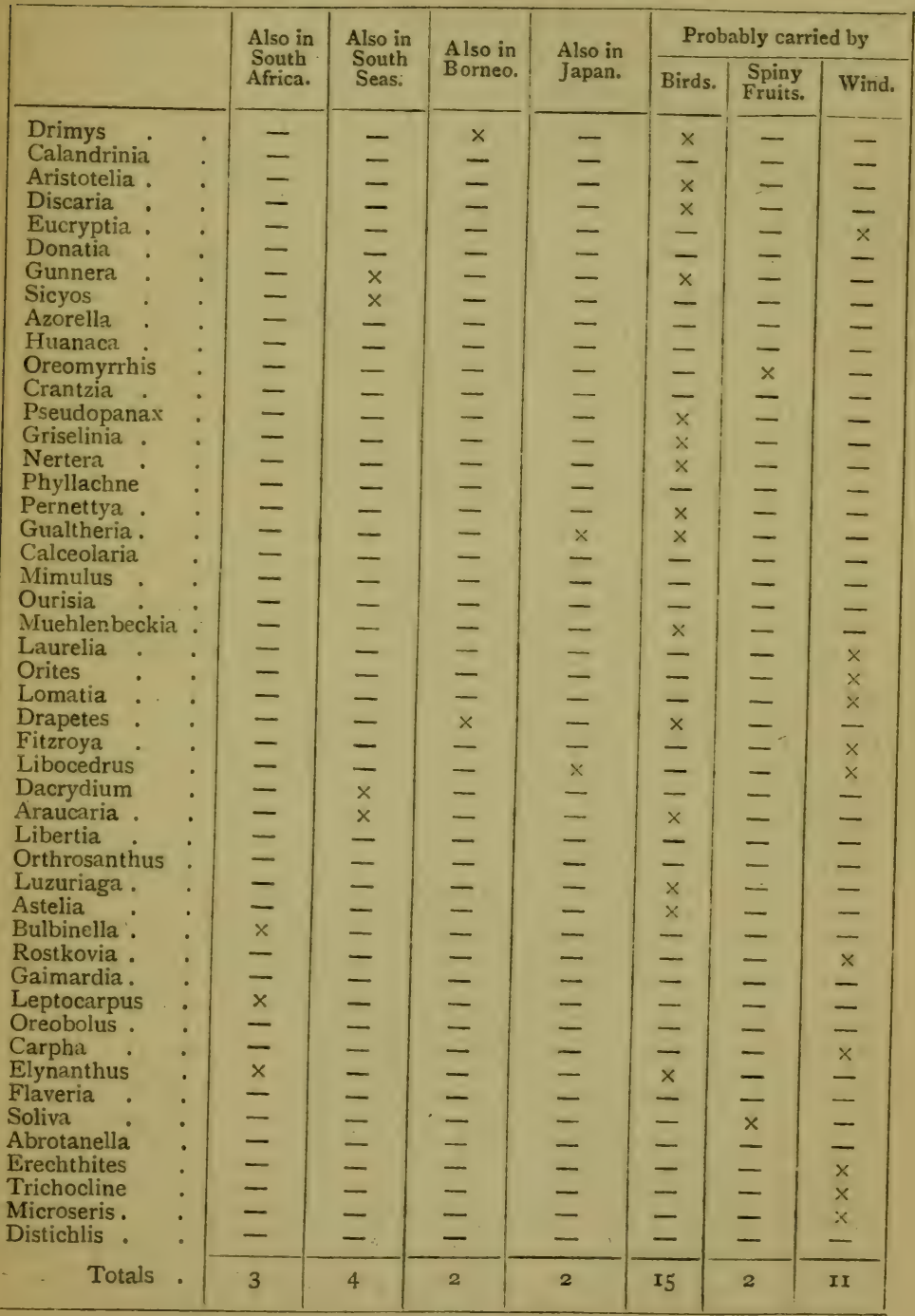




\section{The Antarctic}

So we see that of these fifty plants only 3 or 6 per cent. are also found in South Africa, 8 per cent. are found in the South Seas, and 4 per cent. occur in Borneo or in Japan. The number which are more or less fleshy, and probably carried by birds, amounts to 30 per cent., to which the two spiny forms have to be added. The neat little fishhook of Oreomyrrhis is beautifully contrived to catch in the feathers of a bird. This would make 34 per cent. carried by birds, which is an unusually high proportion. The wind-carried seeds amount to about 22 per cent., which is not above the average in most places.

Further details must be sought for in Dr. Reiche's valuable monograph on the Vegetation of Chile, from which this table has been compiled.

It is extremely difficult to give any realistic account of the sort of beechwood which exists on the stormbattered slopes of Fuegia and South-Western Chile.

It is very rarely seen, for snowstorms or sheets of rain driven by a furious westerly gale generally prevent any view of them. The wood is mainly antarctic beech, gnarled, much-branched, stunted and miserable-looking, crouching in the hollows of the hills, and not climbing very high up the slopes. These woods are exceedingly difficult to get through, always dripping with moisture and with a saturated peaty or mossy soil underfoot. Even from the short list given, it will be noticed that there are fine ornamental shrubs represented (Gualtheria, Pernettya, \&c.), but there are many others, such as Fuchsias and Desfontainesia, which belong to the American group, and have colonised southwards. Above the beechwoods are the alpine green cushions composed of moss-like flowering plants as well as peaty mosses, stretches of what look like grass or sedge, and on the summit black rocks and pure white permanent snowfields. 


\section{The Antarctic}

From the graphic descriptions of Mr. Cockayne, the Snares islands seem to be very peculiar. Where exposed to the wind, the ground is covered by great tussocks of a grass, Danthonia, which seems to form its own peat apparently, like our cotton-grass. Where there is some shelter, the ground is covered by scrub. If it is of Suttonia divaricata, it may be as high as one's waist. One can crawl underneath the branches or walk over the top of them, or one may sit down and roll over the tops of these shrubs. In getting to his camp (only a mile away), from the top of a hill 700 feet high, two and a half hours were occupied.

On Ewing island, a regular forest of Olearia Lyallii occurs. This has been destroyed in other places by a better developed vegetation of Metrosideros lucida or "rata."

The enormous numbers of sea-birds insure a plentiful manuring of the soil, and the wallowing of the sea-lions has also greatly altered the vegetation.

If one compares what vegetation has managed to do in the Antarctic and in the Arctic, one cannot help an impression that those beeches of the Southern Pole are perhaps more efficient than the pines, spruce, and larch which are the most northerly woods in the Northern hemisphere.

At any rate they are closer grown and accumulate more humus than the pinewoods of the North (see p. 236).
1 Hooker.
2 Chardot.
${ }^{3}$ Fries. 4 Reiche.
5 Weindorfer.
${ }^{6}$ Cockayne.
7 Arctowsky, Murray. 


\section{CHAPTER X}

\section{FLOWERS}

THE interest in botany of many of us undoubtedly springs from a love of flowers.

There is nothing modern about this appreciation, for we find that men and women in the very oldest civilisations, from which we have any satisfactory evidence, not only delighted in flowers, but had the oddest and strangest symbolisms drawn directly from buds and blossoms.

One has but to remember the story of "lovely Thais," the friend of Alexander the Great, of Mænander the poet, and who became the spouse of Ptolemy, King of Egypt.

When the mummy of this famous beauty was discovered, it held in its withered hand a plant of the rose-of-Jericho, of course a symbol of the resurrection. ${ }^{1}$ When this well-known desert plant is placed in water it uncurls and revives, becoming fresh, green, and vigorous.

Lovely Thais hoped that she also would enjoy immortality.

One French author at once and unhesitatingly declared that she must have been a Christian. One would scarcely have supposed so from what little has been recorded of her life, but. as a fact she died many years before Christ was born.

But in Egypt, Assyria, and Babylon poets compared i 08 


\section{Flowers}

their queens of beauty to flowers, and priests used them in church services, and the guests at convivial entertainments were always decorated with wreaths and garlands.

To the botanist, however, such an apparently simple question as "What constitutes a flower?" raises abstruse and almost metaphysical controversies which are either intensely attractive or entirely abhorrent, according to his own particular personal magnetism or the botanical ways in which he has been brought up.

It is perhaps the most difficult question in the whole great science of botany, and will undoubtedly be earnestly discussed in 2009 A.D.

But there is a much more interesting and practical question, which is, how did flowers manage, when once formed, to vary and multiply into the exquisite forms and lovely colours in the world's flora of to-day?

A flower may be compared to a foliage bud which has never elongated. The uppermost leaves have been modified to produce the egg cells or female germ cell ; the stamens bearing the pollen, of which the grains are sperm cells (male), are also modified leaves, and the petals and sepals are also in all probability modified leaf-like organs.

It is quite likely that the petals of many flowers were stamens in a previous ancestry, but on the whole it seems most reasonable to assume that both petals and sepals are for the most part modified leaves, devotees of the flower and changed in appearance accordingly.*

* The carpels or egg cell leaves are greatly altered in form but often remain green. A pea pod is a typical carpel; wallflower has two carpels; lilies have three carpels; geraniums have five carpels; buttercup has many free carpels arranged spirally and is nearer the primitive type. The ovule or young seed which contains the egg cell is supposed by Worsdell ${ }^{2}$ to be a three- 


\section{Flowers}

The sepals are sometimes, surely; only protective bracts which have been further modified. Either sepals or petals and sometimes both of them become abortive. Occasionally petals become stamens, which may mean that in those cases they were at first modified stamens. ${ }^{3}$

In a sense one might say that flowering is the end towards which every effort of the plant is directed. Quite a number of the Monocotyledons die as soon as they have flowered. Young trees which are unhealthy and miserable-looking often produce great quantities of flowers and fruits and at a very precocious age, long before their normal and vigorous contemporaries show the slightest desire to flower. One might suppose that such miserable seven- or eight-year-old trees had a foreboding of death and wished to do what they could to perpetuate the species. One sees the same hurried flowering also when cut off leaves of Torenia are induced to take root. The ugly little stems so formed flower when only an inch or two in height.

But such facts do not necessarily bear out any such explanation.

In a flower, the life that is going on differs in many ways from the ordinary proceedings in other parts of a plant's body. There is a very active formation and storing up of rich proteids, sugars, hard stony substances, colouring materials, strong perfumes and the like, which may not be required anywhere else except in the flowers. So it is not surprising to find that the temperature in an opening flower is often distinctly higher than that of the surrounding air. So also the respiration in

lobed leaflet carrying a female sporangium. Bower thinks that all green leaves were at one time spore-leaves and only intended to bear a sporangium. Gradually more and more of their cells became sterile and ceased to produce spores, but this refers to the time when the plants were primitive ferns and long before flowers appeared. 


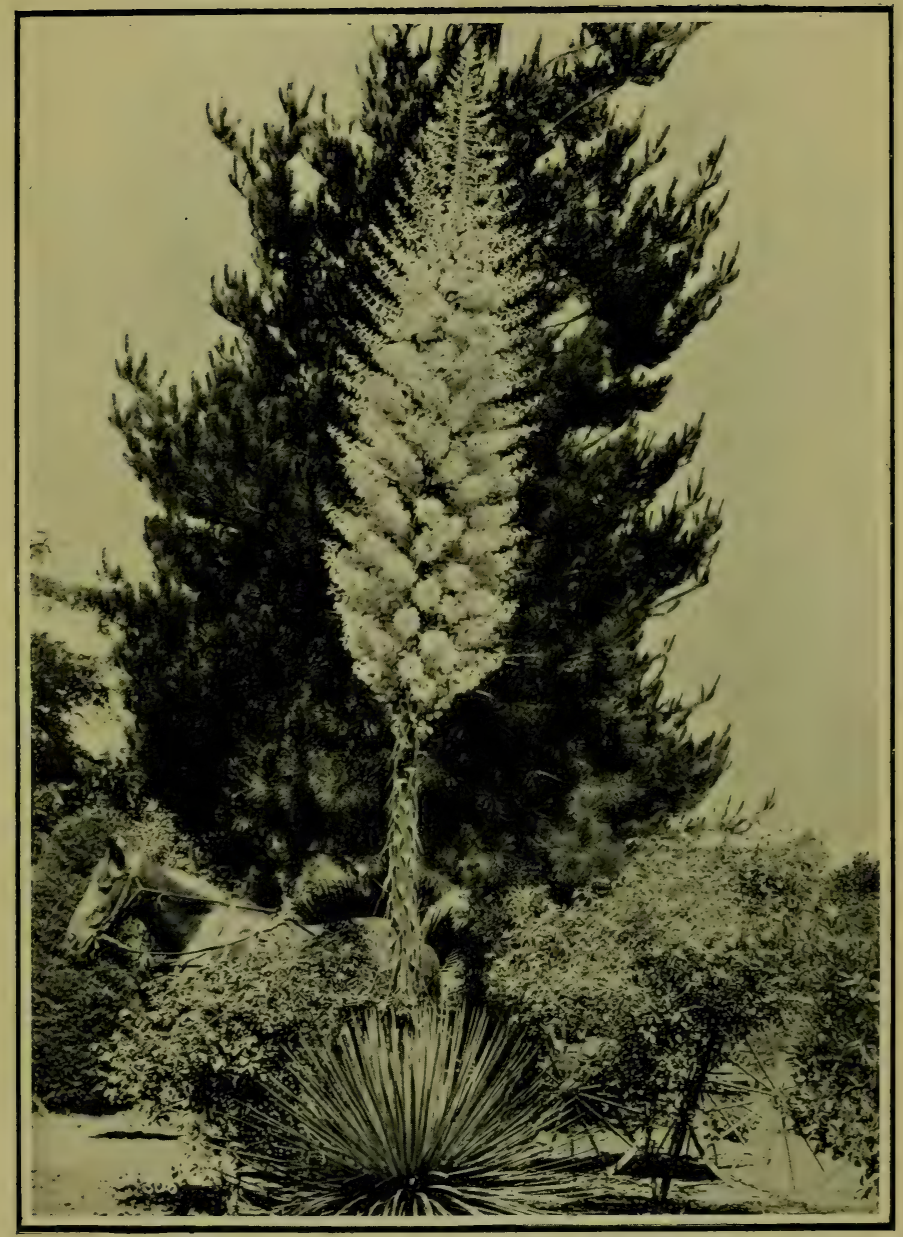

Stereo Copyright, Undcruood \& U.]

[London and New York

A YuCCA IN BLOOM

The production of this enormous inflorescence ends the life of the plant. 



\section{Flowers}

flowers is intensely active, and is much more vigorous in the case of petals than with ordinary leaves.

The precocious flowering of leaf-cuttings and sickly trees might be due therefore simply to the increased respiration which is a result of their unhappy situation (see p. 332).

There is every reason to believe, from what we know of modern club-mosses, fern-spores, and moss-capsules, that the original flowers were yellowish. That is also very probable from the ordinary development of the green chlorophyll of leaves. ${ }^{4}$ The colourless plastids first become yellow (Xanthophyll) and then turn green.

In a developing petal, the great demand for food material of the stamens and carpels might well prevent the formation of the green colour. Then one of two different things may have happened.

The process of economising might have been continued by suppressing the formation of the yellow, leaving the petals pure white. Or the yellow may have been changed into red, similar to that of some fading autumn leaves, and which is due to chrysophyll or carotin.

Other colouring matters seem to have then appeared, probably developed independently through the action of enzymes or in some as yet unexplained way.

The proportion of the various colours has been calculated by Kerekgyarto, ${ }^{5}$ who found the percentages to be as follows :

\begin{tabular}{|l|c|c|c|c|c|c|}
\hline & Green. & Yellow. & White & Red. & Blue. & Lilac. \\
\hline $\begin{array}{l}\text { Monocotyledons (207 species) } \\
\text { Dicotyledons (1795 species) }\end{array}$ & $\begin{array}{l}2.12 \\
6.28\end{array}$ & $\begin{array}{c}29.82 \\
\mathbf{1 2 . 0 7}\end{array}$ & $\begin{array}{c}32.23 \\
\mathbf{1 6 . 9}\end{array}$ & $\begin{array}{l}\mathbf{1} 8.23 \\
\mathbf{2 5 . 1 2}\end{array}$ & $\begin{array}{c}8.99 \\
3.91\end{array}$ & $\begin{array}{c}4.73 \\
4.90\end{array}$ \\
\hline
\end{tabular}

Unless, however, one could investigate all the 170,000 kinds of flowers known, one would not have the data from whichto draw conclusions. 


\section{Flowers}

The genealogy of the colours might then have been as follows :-

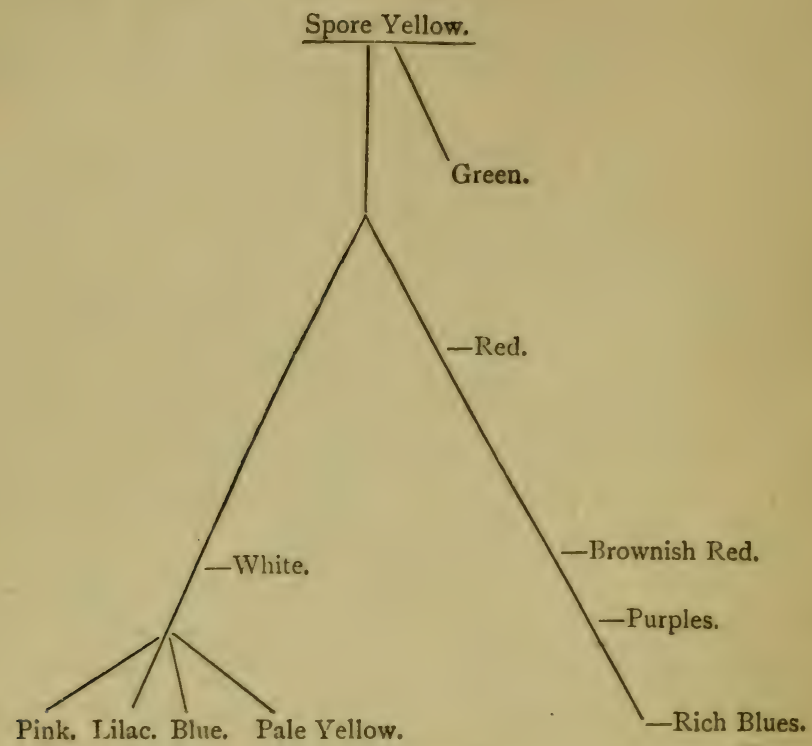

The Spore yellow is extraordinarily common, for we find it in pollen, fern-, moss-, and some algal-or fungusspores. Nor is the change from yellow to red confined to flowers, for reddish-yellow is one of the commonest colours of lichen-cups, of rust-fungi, cluster-cups, and even in the Alga Chara we find this same shade.

Strong sunlight has surely something to do with the development of crimsons, rich blues, purples, and the like.*

Bonnier, Kerner von Marilaun, and others have shown that lowland flowers, when transferred to alpine gardens at 6000 feet, become richer and deeper and more vivid

* The mysterious reddish substance anthocyan seems only to be formed when a process of oxidation is going on. ${ }^{6}$ 


\section{Flowers}

in colour. The reverse experiment is equally true, for natives of the mountains become pale and dull in colour in the heavier lowland climate.

The most vivid crimsons, flaring yellows, blues and purples are a very marked character in most open floras, but above all other places it is the limestone hills near Alexandria which the reader should visit if he clesires really to understand the possibilities of flower colours. It is a semi-desert, and probably resembles many parts of Palestine. There one finds bright yellow composites, scarlet poppies and ranunculus, the orange-red of calendula, quantities of starof-Bethlehem, of moræas and antirrhinums which, though often only 4 inches high, vary in the most extraordinary way from yellow, with or without orange or golden-brown marks, to mauves and blues. Every plant almost ends in flowers, and there is no turf or dense foliage to conceal them.

On the other hand, want of sunshine may arrest the formation of flowers and preserve them as tiny cleistogamous self-fertilising buds which are scarcely or not at all coloured. These are, according to Goebel, often formed as a result of weak or insufficient light, though anything which starves or hinders the plant from growing properly may produce them. ${ }^{8}$

Just as sunshine and pure air seems to be responsible for many of the brilliant colours of flowers, so also perfumes are said to be especially strong and rich under the same conditions. Sunshine and pure mountain air distinguish those places in the near East where whole villages live by the preparation of attar-ofroses. ${ }^{7}$ In sunny Spain, ${ }^{9}$ whole woods are fragrant with the scent of laurel, and the winds from Corsica are also real spicy breezes, which can be smelt a long way off shore. 


\section{Flowers}

There are some interesting cases which show how co-operation prevails between leaves and flowers, or even amongst the flowers themselves.

In the gorgeous Bougainvillea, a great favourite in tropical and sub-tropical gardens, it is the bracts that are flaringly conspicuous, but even more interesting is the common bluebeard salvia of our own borders. A fine dark blue has appeared in the uppermost leaves, which are of course most exposed to the sunshine. The actual flowers are small and provided with lightblue patches and yellow hairs. This is an ingenious effort towards both economy and efficiency, for the flowers are short-lived, whilst the large attractive leaves last during the whole season.

A tropical orchid (Renanthera Lowii) has a different arrangement. In each spray of flowers the two uppermost are a bright sulphur-yellow with red dots or splashes upon them. These two have a very strong scent and last for a very long time. The other flowers are only white with brown dots; they have no scent at all, and only live from seven to thirteen days.

So the attractiveness of the two uppermost answers for all the others. ${ }^{10}$

It is of course to attract insects that these colours and perfumes have been so richly produced in nature. Aided by their own excessive respiration and high temperature, and favoured by the sunshine, petals have formed all these exquisite shades and scents. But they have been from the beginning favoured and guided by the more inquisitive and therefore more intelligent of the insect-world.

In the gloomy, misty atmosphere of the coal-measure swamp-forests, not very clever insects would surely fly to the yellow spores of the fern-seed plants, and no doubt eat the spores. 


\section{Flowers}

From that distant time until to-day every change in colour or in form has had to be exposed to the insect's eye. Those changes which found most favour have been perpetuated.

In this process there is nothing at all more mysterious than the selection exercised by those nurserymen who produce yearly new varieties of turnips or potatoes, but it is the insects who select and discard (see p. 285).

Not long ago the scientific world was alarmed and disturbed by a certain botanist, who declared that insects were not attracted by colour but by scent.

Proof, though not in the least required by any of those who had studied the question, was very soon forthcoming. When one single petal of a composite could attract bees, it was of course obvious that neither scent nor the shape of the flower, but colour alone, was the important point. ${ }^{11}$

An observation of Dr. Ridley's is too interesting to leave out ; it reminds us of certain Athenian birds which pecked at Apelles' pictures.

Dr. Ridley, when passing through the Suez Canal, happened to be in the smoking-room of the steamer, which was decorated with white enamelled tiles on which flowers were represented. Some of these were "cup-shaped, more or less resembling a tulip," and the alternate ones were conventional composites. Certain "humming-bird hawk" moths were in the smokingroom, and he noticed that they were trying to probe the mouths of these conventional flowers. As they had no scent of any sort or kind, it is clear that the moths were attracted by the colour. ${ }^{12}$

But this would never have been doubted by any one who had taken the trouble to watch for insectvisitors on wild plants when growing in their natural homes. 


\section{Flowers}

In gardens the plants are unnaturally placed and unnaturally visited, so that observations, which can be very comfortably made in a garden, are unfortunately of no value whatever.

The close connection between the insect-world and the flowers which they visit is not at once manifest.

The two have varied together, the first stupid sort of insect was surely as different from a bumble-bee or a butterfly as the clumsy, yellowish and ugly flowers of a Cycadofilix differ from those of an orchid or a salvia. When one remembers this fact, much that is not at once obvious becomes clear and manifest. For instance, there is a distinct change in the various sorts of flower. In spring, the larger proportion are of the open type in which honey is easily obtained. The majority of our richly coloured, complex flowers with concealed honey appear in summer, whilst those with honey halfconcealed and accessible to short-lipped insects, are mostly autumn flowering.

At least this is what has been recorded as the result of two large series of observations taken in quite different places, viz., Robertson, Carlinsville $\left(39^{\circ} 3 \mathrm{I}^{\prime} \mathrm{N}\right.$. lat.), in America, and Brandenburg in Germany. ${ }^{13}$ This general correspondence suits exactly with what is known of the insect-world. The majority of insects with long proboscids occur in summer, those with medium-sized in autumn, and those with a short proboscis in spring. ${ }^{14}$

We know also from geological records that the great classes of flower-insects appeared in the Cretaceous period just as suddenly and along with the true flowering plants.

But how difficult and complex are the modern relations between flower and insect, and how impossible to catalogue and classify are the types of visitors!

In July and August one finds every sort of flower. I 6 


\section{Flowers}

Some, like those London shops which are frequented by peers and peasants, satisfy every sort of insect, from the small fly to the hive-bee. There are small, cheap, economically-produced, white and yellow flowers (such as the crucifers) which do a small trade with ordinary flies, beetles and the like, and whose clients might be afraid of sucking honey beside bumble-bees and suchlike pretentious personalities, just as the small "general" shops of unfashionable London (that is, less valuable ground) are visited by poor customers. Then there are also large complex flowers, rich crimson, like red clover and Stachys silvatica, or with the deep blue of ajuga, purple of aconite, gold yellow of broom and whin, which only cater for insect-aristocrats. These flowers, like shops in Bond Street or Regent Street, are expensive to make and keep up, and would not be of any use to the general public. There are also many "specialists" which lay themselves out for one special and particular visitor. Figwort (Scrophularia) is a wasp-flower, and seldom used except by wasps. Veronicas, with little blue blossoms and two diverging stamens, are clearly intended for the small glancing hoverflies which visit them conscientiously, gathering the stamens under their legs and probing the tube for honey. Even such a very odd-looking flower as the fumitory is specially intended for the cabbage white butterfly.

Perhaps the most interesting of all are the white evening flowers with long tubes and strong scent, such as evening campion and honeysuckle, which are frequented by evening moths. The moth has an evening habit, a long proboscis, and well-developed olfactory lobes. The flower opens at dusk only, has a long tube, and a strong fragrance which is only perceptible at night.

These two, the evening campion and the moth, have 


\section{Flowers}

been isolated, as if on an uninhabited island, and have changed together, developing side by side, "the world forgetting, by the world forgot."

There is a charm and a variety in the study of the first appearances of flowers and their hours of opening and closing which affected even the great Linnæus, who himself prepared a so-called shepherd's clock. It is extremely unlikely that any shepherd would make use of it, for if the sun were above the horizon it would be unnecessary to look at the flowers; if the day were overcast, the flowers would, in some cases at least, remain closed. Linnieus' clock begins at 3.5 A.N. when the goatsbeard opens, and stops at midnight when the large-flowered cactus closes its petals.

The opening and closing of all flowers seems to be indirectly regulated by the hour of sunrise. Kerner van Marilaun's floral clock, drawn out for Innspruck, brings this out very clearly. ${ }^{15}$

Our own hours of work are indirectly regulated by the sunrise also, even those of some amongst us who begin to work just when the majority of people go to sleep. The journalist and the night-watchman have to work in the evening, just as Lychnis vespertina has to do and for similar reasons.

Strangely enough there seems to be a great variation in the power of habit among flowers. A tulip or crocus will open widely at night when they are brought near a paraffin lamp, but a daisy will not do so. Daisies will open at their usual hour, or very near it, even if they have been kept in a dark cupboard, whilst the wood-sorrel will more or less close its flowers even when a dark cloud passes across the sun at midday.

It is the same with us, for some will waken at the correct hour in the morning whether the day is bright I 8 


\section{Flowers}

or shrouded in the felt darkness of a London fog, whilst others will always oversleep themselves.

Early in the season, when the weather is favourable, one finds the first flowers and first insects. Later, as summer approaches, one finds various times of the day utilised by certain flowers and their visitors until the complex variety of July and August is attained. After these months the number rapidly diminishes, but varies according to the weather. Even late in November of I908 I found twenty-four flowers open along three miles of a roadside; four were grasses that had also blossomed in spring. This is one of the simplest of the fitting reactions which have been so often referred to.

Flowers are not only specialised but are also most adaptable to circumstances.

The secretion of honey is another very interesting character. Professor Henslow's theory, that the continual visits of insects and their bites and scratches have produced the honey-secretion, has not been adopted by many botanists. Sugar is, of course, very common in plant tissues, for it is as some form of sugar that the products of assimilation travel about the plant. Such sugars will certainly diffuse to any part of the plant where it is required. If it exudes and is taken by insect visitors, then less sugar will be available for the building up of stamens or petals, so that there might easily be a tendency for petals or stamens to become first honey secreting, then reduced, and finally nothing but nectaries.

If one compares the long spur of many orchids (usually formed in the modified petal called the lip) with the honey spurs of the columbine, of larkspur, of violets, of Linaria (Toadflax), the resemblance is very remarkable. All these are honey-secreting modifica- 


\section{Flowers}

tions of petals or sepals, or in the orchid (probably) of a petal and two stamens. One has simply to suppose that the continual loss of honey at one point of the petal has caused a similar extra growth of the tissue, which has continued to "give" until it has formed the long narrow spur which is curved in accordance with the curvature of an insect's proboscis.* In the buttercup petal one sees the beginning of the process, which has proceeded so far in the aconite that nothing is left of the petal except a spurlike nectary.

But this involves the inheritance of an acquired character, which point is to be considered elsewhere (see p. 295).

Wax sometimes occurs on the epidermis of leaves and stems, and in some orchids there is an extra development of wax on certain parts of the flower. Here it replaces honey, for bees take it to form propolis, and being sticky and slippery it keeps off small insect thieves which are not desired.

Besides colour, perfume, and honey or wax, there are thousands of other interesting modifications by which they have been made attractive to their average insectvisitor, and at the least possible expense of material.

That flowers do change in such characters as size, colour, number of ray florets and the like, has been abundantly proved by laborious arithmetical calculation (see p. I 88). Thus the spots on a certain orchid (Orchis morio, var. picta) were found to vary as follows. In the island of Majorca the majority of the flowers had five spots, in Belgium six, in English and Scandinavian specimens nine was the commonest number, whilst flowers from more continental places had eleven spots. ${ }^{17}$

Another stock subject for such arithmetical researches

* De Vries ${ }^{16}$ mentions these cases, but does not adopt the obvious suggestion given here. 


\section{Flowers}

is the number of ray florets in the heads of various composites. It has been found that the American Aster prenanthoides varies in this respect according to the season. Early in the year, the average number of ray florets is small ; they reach a maximum in summer, and then gradually decrease again. But towards the end of the season there is often a slight increase in the average number of ray florets. ${ }^{18}$

So that there really is a variation in flowers when tested by statistics, which is a very important point.

In a systematic account of the genus Erigeron, it was tried to trace the history of the various changes. In Linosyris, for instance, (I) all the flowers in the head are similar. (2) In the next stage some of the outer florets have lost their stamens. (3) Next these outer florets became threadlike and altered in shape (as $e . g$. in Conyza), by the petal-tube contracting on the style. (4) Some of these outer florets enlarged their petals and became ray florets (Trimorpha). (5) These attractive florets became sterile, and the inner threadlike florets became female only. ${ }^{19}$

For these changes to have happened, one would like to know how, for instance, the flowers in the second stage lost their stamens.

But when a kind of savoury (Satureja hortensis) is cultivated in particularly poor soil, it shows a tendency to suppress its stamens.

As a rule, in this plant 79 per cent. of the flowers possess both stamens and carpels, but in very poor soil this may sink to 17 per cent. or even I 3 per cent. Also, at the end of the season, almost all the flowers have no stamens at all. ${ }^{20}$

So such changes as those of Erigeron are not necessarily inexplicable, they may be directly connected with the climatic conditions. 


\section{Flowers}

The changes which Dr. Klebs ${ }^{21}$ was able to bring about in flowers, simply by altering their conditions of life, are even more remarkable than any of these instances.

Those who have themselves studied the intimate connections which exist between flowers, insects, and the outside world, must surely be convinced that every detail in the structure of a flower is of real importance. Useless characters are exceedingly rare, or more probably do not occur.

An excellent example may be quoted here to show how difficult it is to find a useless character. There is a very queer resemblance in the flowers of bee orchis, spider orchis, and fly orchid to their insect namesakes. Surely this must be of no use whatever to the flowers concerned.

Two of these, Ophrys apifera and $O$. araneifera, are visited by a certain small fly (Sarcophaga cernaria). Bumble-bees are not wanted by these flowers, being too large and vigorous for such delicate blossoms. Some of the bee orchid were cut off and placed on pæony, comfrey, and bryony flowers. The bumble-bees avoided those flowers, apparently supposing that another bee was visiting them.

They also avoided flowers upon which the spider orchis had been put, for this made them look like little grey flowers on which a large spider or butterfly-like creature had seated itself. ${ }^{22}$

So the mimicry of these orchids may really be of some use!

At the same time, it is always possible to be a little too clever, or rather to specialise too much, for the same author found that in 1903 only 29 out of I 388 flowers of O. muscifera had set seed (2.I per cent.), and in r 904 only 79 out of 1048 flowers ( 7.5 per cent.). 


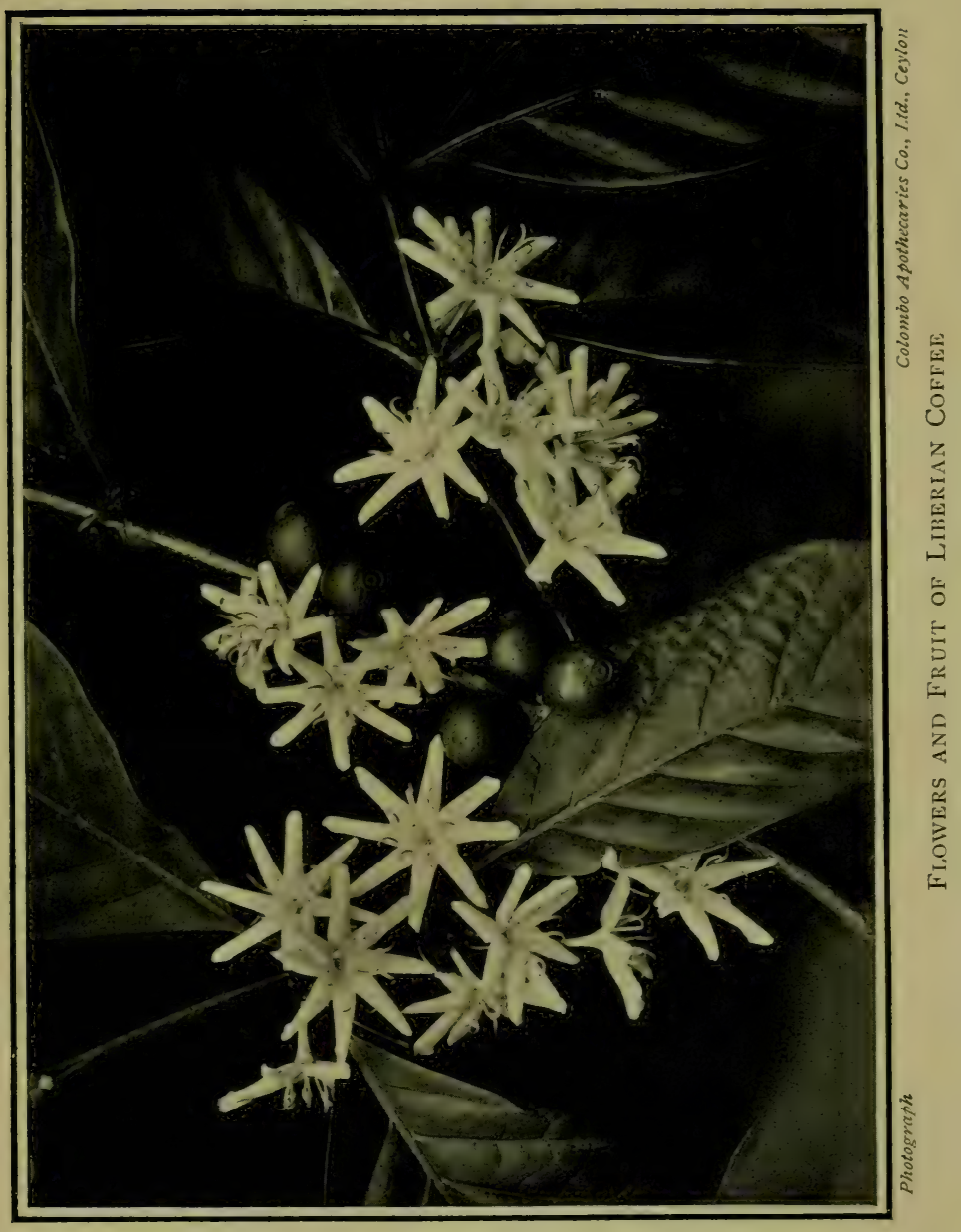





\section{Flowers}

The spider orchis succeeded in getting only 6 to 8 per cent. of its flowers fertilised.

Quite as wonderful are the ways in which flowers arrange their reactions to light and sunshine so that the movements of the stalk at every stage are exactly what suits its purposes best.

The common Geranium pratense is a very interesting example. At first the flower-stalk grows upwards; then, as soon as the flower develops, its own weight causes it to droop or hang downwards.

Soon the flower becomes again erect, which is brought about by a response in the opposite direction to the action of gravity, or, as it is called, negative geotropy. Then the flower turns a little so that its petals are nearly in a vertical plane (weight and negative geotropy).

After flowering the young fruit hangs downwards, but as soon as it is ripe, gravity again stimulates it and the mature fruit is upright and, by the growth of the stalk during its ripening, keeps well above the grasses and herbage, so that it is in the most suitable position for distributing its small carpels. ${ }^{23}$

So by this extraordinary series of fitting reactions, it does what is best for itself at every stage of development.

Even from this short sketch it will be seen that a modern flower is a very complex product. Its own sensitive protoplasm and the delicate balance of supply and demand between root, stem, leaves, and blossoms are sufficient to explain why changes in sunshine, in rainfall, and in soil should produce slight tentative variations.

But these variations are not allowed to develop riotously and unchecked. Each attempt has not only to prove itself fit to withstand weather and insectenemies, but it must be a more alluring enticement to artistic and intelligent insects. 


\section{Flowers}

Nothing has hindered the development of our knowledge of evolution so much as certain vaguenesses in the popular idea of the term "Selection." Selection cannot be rightly described as a cause, any more than a locked gate across one path can be said to force a man to proceed along a different one. Neither a gardener, nor a plant-breeder, nor even an insect visitor can be said to produce any particular variety, but they can, and, in practice, do prevent a bad development from being perpetuated, and they also help forward any encouraging varieties which happen to make their appearance.

Insects, weather, and the sensitive protoplasm itself, are all necessary to explain the origin of flowers.

Neither insects alone, nor environment only, nor some inscrutable mutability or doubtful-mindedness of the plant itself can ever explain this mystery. It is a threefold influence that has been, and still is, for ever working out yet more exquisite gracefulness and lovelier colours than the world has ever seen.

1 Steinbrinck and Schinz.

4 Schunck.

7 Charabot.

10 Winkler.

13 Loew.

16 De Vries.

19 Vierhapper.

22 Detto.
Worsdell.

5 Kerekgyarto.

8 Goebel.

11 Detto, Giltay.

14 Loew.

17 Chodat.

20 Correns.

23 IViesner.
3 Worsdell, Nicotra.

${ }^{6}$ Buscalione e Traverso.

? Willkomm.

12 Ridley.

15 Schulz.

18 Shull.

21 Klebs. 


\section{CHAPTER XI}

\section{RECONQUEST OF THE WATER}

WHEN the plant world had finally reached the land and had varied into orders, families, and species, which again had suited themselves by experience and temperament to such places as they found, then a new field of conquest presented itself.

This was nothing less than a fresh occupation of the water.

On the borders of lakes where the ground is moist and often supplied with fresh silt from the floods, the competition and crowding amongst plants is often very severe.

Some of these bordering plants began to adapt themselves to a life below water. A great many even of our ordinary herbaceous and shrubby forms are not in the least injured by floods.

By slow degrees certain natural orders or individual species discovered how to live a purely aquatic life, and became partly or wholly submerged.

The first difficulty which they met with was the obvious danger of being drowned. Plant cells, like those of animals, require fresh oxygen for respiration, and this was difficult to get when leaves and shoots were plunged many feet below the surface.

In all such water plants there is a complex system of air-spaces and channels inside the stems and roots, and often within the leaf also. This constitutes an internal atmosphere and is, no doubt, supplied with oxygen from that which is given off in assimilation. The origin of 


\section{Reconquest of the Water}

these air-spaces has not been explained; but as the epidermis and the tissues generally in such aquatics are very weak and soft, there is but little resistance to growth and expansion; perhaps the oxygen formed in the green cells passes into the intercellular spaces instead of escaping into the water through the cellulose of the epidermis.

That, however, is but an unproved suggestion, whereas the spongy nature of aquatics is a fact, and one that is of great importance to their livelihood.

These aerated tissues are extremely buoyant, which gives them many great advantages. Such a floating plant as the Florida hyacinth is quite unsinkable. Its curious rosettes of fleshy leaves with spongy, goutylooking leaf-stalks are most ingeniously constructed. If one upsets the rosette in the water, it slowly and solemnly rights itself. It seems to grow very quickly, pushing out long buoyant runners, and twenty to thirty of these leaf-rosettes may belong to one plant.

It has been proved guilty of many crimes. In the St. John's river, for example, its inordinate multiplication stopped the lumber rafts and steamer traffic (for the paddles were choked by the quantities of weed); fishing was brought to a standstill, and even the climate became unhealthy through the masses of decaying vegetation. ${ }^{1}$ One sees the sponginess of water plants turned to advantage in other ways also. Both fruits and seeds being full of air cavities are easily distributed by the water. Sometimes it is the carpel, or it may be the seed-coat that becomes full of cavities. In Nelumbium it is the central part or axis of the flower that is able to float.

The sponginess is clearly, then, a "fitting reaction" due to water life, and has been made use of for quite different purposes. 


\section{Reconquest of the Water}

One can see also how other peculiarities, which are common to most water plants, have turned out to be useful instead of detrimental.

There is a general softness and flaccidity about them. Lignin (woody matter) and cork is but little developed. The main stem of the reedgrass, Phragmites, cannot stand erect, but lies lengthwise in the water, giving off its upright foliage and flowering shoots with their wonderfully contrived leaves and feathery sprays of flowers. "Prone on the flood, extended long and large," such a stem, perhaps 40 to 50 feet long, is of great advantage, for, as we shall see later, this method of growth has been essential to the formation of alluvial meadows (see p. I 33).

The evidence upon the effect of water-life is unusually complete and satisfactory owing to the researches of Costantin and especially Henslow.* It is not only that there is a vast body of aquatics which agree in the possession of certain characters, but there are such plants as Polygonum amphibium and Ranunculus aquatilis which both live on land and thrive in the water. These amphibious species take on sponginess, lose their hairs and most of their woodiness, and alter the character of their leaves promptly when transferred from land to water.

Wholly drowned leaves, such as those of many forms of pondweed (Potamogeton), and water crow's-foot, water milfoil, and the like, are generally slimy, often finely divided, long drawn out and much branched. The slimy character (due probably to the more mucilaginous character of the cellulose) prevents friction with the water, and in other respects the leaf simply yields itself to the current, and is, so to speak, "combed out" by it.

* Costantin, Henslow. The adverse criticism of Freidenfeldt is not clearly expressed, for one has only to compare the types given by Bonnier ${ }^{2}$ to see how distinct is the water type. ${ }^{3}$ 


\section{Reconquest of the Water}

From the very moment when these tiny infant lobes emerge from the protecting mother-sheath, the gentle pulling and swaying of the current is acting upon them and they yield to it; indeed, they are always swaying to and fro in the water, and in rivers seem never to rest at all.

According to one authority, it is sometimes possible to produce the air-type of leaf under water by using certain salts, which probably check the ordinary expansion of submerged leaves. ${ }^{5}$

The real difficulty of water plants arises when flowers have to be produced. In almost all cases the flowering branches rise up above the surface, so that the stamens and pistils are exposed to insects or the winds. But the long-stalked water-lilies simply allow their flowers to float upon the surface, where they are abundantly visited by bees and crowds of other insects. The beautiful arrangements of Vallisneria have been so often explained that we prefer to describe the Canadian wreed (Elodea), which is not so well known. The female flower has a very long flower-tube (about 4 to 8 inches), which grows rapidly, and finally opens on the surface of the water. It is beautifully buoyed up by three rows of air-spaces, and so shaped that water cannot get into the long funnel-shaped interior. The male flowers break off and float up to the surface, where the stamens open and set free the pollen.

The little grains of pollen are covered with minute spines. Because of these little projecting teeth, an air film surrounds the pollen grain, so that it floats (although itself heavier than water) and drifts about on the surface. Should they by chance reach a female flower, they are drawn by capillary attraction into its funnel and so touch a stigma and effect fertilisation. ${ }^{4}$ The point of this story lies in the fact that many pollen I 28 


\section{Reconquest of the Water}

grains of land plants, as well as the spores of rust-fungi, are also spiny, and by these processes stick to the hairs of an insect's body and so get carried from flower to flower. In Elodea the minute spines are kept, but used for the totally different purpose of entangling an airbubble. A curious fact about freshwater weeds is that many of them are found over enormous areas of the earth's surface. The usual explanation is that such birds as ducks and water-fowl generally are also very widely distributed, and that the seeds are carried in mud sticking to the plumage or legs of these birds. But if a bird happened to be starting on a flight of a thousand miles or so, it would surely take good care to wash its feet and feathers before leaving.

One of the most wonderful arrangements known in water plants is that possessed by a certain Trapella. The small conical fruit has three long fine gracefully incurved spines, which look very well fitted to be entangled in a migrating bird's plumage. But this plant is very rare, having been only once discovered by Dr. Henry in one small tarn in China, so that it does not seem to have succesded in travelling to many places. ${ }^{6}$

But these water plants not only live in water but they also have a very important function, that of changing it into dry land.

The process is orderly and systematic. Each particular group has its own definite part to play, and gives place to another so soon as its work is done.

The method employed for colonising a shallow lake or the quiet backwater of a river seems very much the same in North America, France, Switzerland, or Great Britain. Probably one would find it going on anywhere in the North Temperate Zone, where the climatic conditions are of an average character. 


\section{Reconquest of the Water}

Rowing across such a lake near the shore, one notices a border of tall reeds or bulrushes; behind this, on the landward side, marsh plants are generally to be found, and often in profusion. Above the reeds and behind the marsh plants one may see the foliage of willows, alders, and birches which occupy the border of the land, which is, in their territory, more or less wet and possibly sometimes submerged.

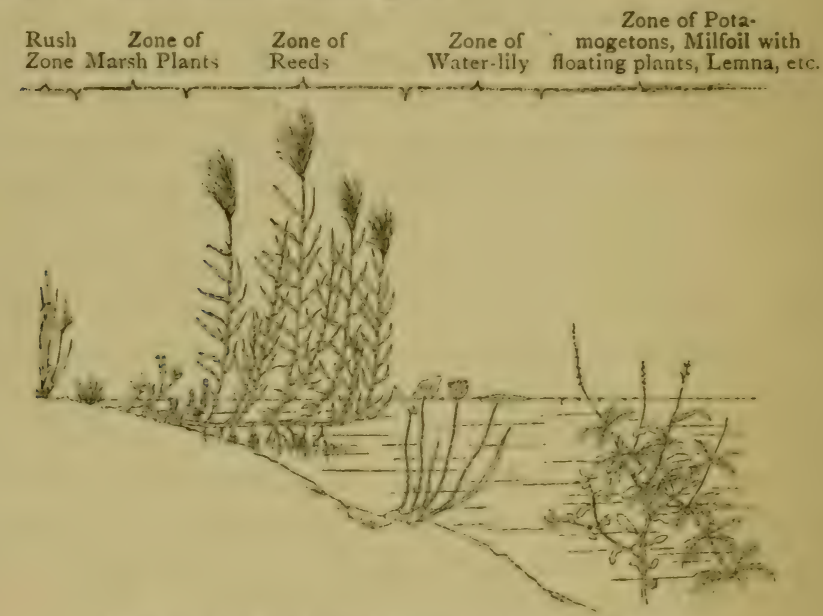

Diagram to show Land-formation by Pond Plants

On the water side of the reeds there is very often a zone of yellow and white water-lilies.

In much deeper water such plants as pondweed, milfoil, and a few others are still able to fourish, and their reddish-brown spikes may be seen standing out of the water at the right season.

But a small diagram is necessary to show how they work together in the process of filling up the lake. The important member of the series is what may be called the "reed association."

It may consist of bulrushes or of Scirpus lacustris 


\section{Reconquest of the Water}

or of Equisetum limosum or of Poa (Glyceria) fluitans, but the commonest and best example of the reed association is Phragmites communis. It is a hardy and common plant, for it grows in New Zealand, America (except the Amazon valley), Mesopotamia, the far north of Europe, and Siberia, in East Turkestan, and in China, as well as all over temperate Europe.

Its prostrate stems, growing to 40 or 50 feet and giving off hundreds of grasping root-fibres, lie in the water. The foliage and flowering stems, of which one springs up at every 5 or 6 inches of the rhizome, are upright, and even in this country may be $\mathrm{I} 2 \mathrm{feet}$ high. But at Niederlausitz bei Luckau, Fruih records a specimen 33 feet high.?

The harshly rustling leaves have a short flexible joint just where they join the sheath, and the plume of purplish white flowers is lifted high above the thicket. These close set battalions of Phragmites stems are the real land-formers, for the submerged main stem is always growing out into the water and so occupying more of the lake.

But two distinct processes are also at work. In the reed thicket there is a continual accumulation of clead leaves and stalks, of drifted silt from the lake, and also an enormous growth of algæ and diatoms. Every season sees layers of fine mud and dead leaves deposited in the reed zone, which gradually becomes shallower, or rather fills up with half liquid mud.

On the landward side of the reeds, marsh plants creep in between the Phragmites stems and here and there succeed in establishing themselves. The process varies almost with every particular loch, and the number of marsh plants which may be found in such a place is very great indeed. Perhaps the most striking are Lythrum salicaria, spearwort (Ranun- 


\section{Reconquest of the Water}

culus flammula), Epilobium palustre, the common Iris, and several grasses.

Then when these marsh plants or rushes have dried up the ground sufficiently, willows, alder, and birch may manage to grow, and in the process of time form small waterside plantations.

The water-lily zone is not perhaps of very much importance, though it is the most beautiful of them all. The stem of the white water-lily is a great, curved, thick, fleshy affair, from which the long-stalked leaves and flowers are given off. Früh records a stem 6 feet long and ro centimetres in cliameter, of which pieces were sold in the public market at Uster as a charm against cramp. The Victoria Regia of the Amazon, whose leaves may be 60 feet across and can bear a weight of 60 kilogrammes ( 132 lbs.), is the finest of the series.

The depths usually affected by these plants and their neighbouring associations are nearly as follows:-

\begin{tabular}{|c|c|c|c|c|c|}
\hline & \multicolumn{5}{|c|}{ Deepest Levels of } \\
\hline & $\begin{array}{l}\text { Marsh } \\
\text { Plants. }\end{array}$ & Reeds. & Water-lities. & Pondweed. & Mosses. \\
\hline Friih (Switzerland) & $\cdots$ & $\begin{array}{l}3.5 \text { metres } \\
\text { (12 feet) }\end{array}$ & $\begin{array}{l}4 \text { metres } \\
\text { (I } 3 \text { feet) }\end{array}$ & $\begin{array}{l}6 \text { metres } \\
\text { (10 feet) }\end{array}$ & $\cdots$ \\
\hline Huron Valley & ... & $\begin{array}{l}2.5 \text { metres } \\
\text { ( } 8 \text { feet) }\end{array}$ & 6 feet & I8 feet & . \\
\hline Magnin (Jura) & $\cdots$ & $\cdots$ & $\begin{array}{l}3-5 \text { metres } \\
\text { (9-16 feet) }\end{array}$ & $\begin{array}{l}6-8 \text { metres } \\
\text { (21 feet) }\end{array}$ & $\ldots$ \\
\hline Bruyant (France). & $\ldots$ & $\ldots$ & $\ldots$ & $\begin{array}{l}8 \text { metres } \\
\text { (26 feet) }\end{array}$ & 75 feet \\
\hline $\begin{array}{l}\text { Forel (Switzerland) } \\
\text { St. Germains, Glas. }\end{array}$ & $\ldots$ & $\ldots$ & $\cdots$ & $\ldots$ & 180, \\
\hline gow. . & I $\frac{1}{2}$ foot & $4 \frac{1}{2}$ feet & $9 \frac{1}{2}$ feet & ... & $\cdots$ \\
\hline
\end{tabular}

The mosses shown in the last column seem to be able to grow at the greatest depths. Those small greenish grey Algæ, the Characeæ, have been found at depths even of 90 feet, but they are not usually found when a 


\section{Reconquest of the Water}

regular reed and water-lily association occupies the lake shore.*

The rapidity of the process of filling up a shallow lake as sketched above depends on so many varying factors that it is almost impossible to give any estimate at all.

The depth, direction of, and exposure to winds, and the character of the streams entering and leaving a lake, are all important factors.

As a rule the process of filling up begins where drift accumulates, but all sorts of things may have an influence. Loose gravel set in motion by the waves, or ice grinding along the shore in winter, may hinder the growth of vegetation. ${ }^{8}$ Even ducks and geese entering the water at one particular place seem to prevent the growth of the regular colonisers.

Our rich alluvials, the hay meadows or "ings" of the first Saxon settlers in Britain, were formed after this manner (see also Chap. XXIII.). Such land may be worth $£_{5}$ to $£_{6}^{6}$ per acre in annual rent, for it is upon it that the richest crops are grown.

But the importance of the process is at once obvious when one reflects upon the valleys of the Thames, Clyde, Severn, the Wash, the rich alluvials of the Rhine, Danube, or Yangtsekiang, and especially on the land of Egypt.

Lower Egypt seems to have been once a land of wild fowls and hippopotami, probably very similar to the Sudd country of the Upper Nile to-day.

When the Nile has left the Albert Nyanza and traversed the steep slope from Wadelai and Nimule to Gondokoro, the country becomes a vast and nearly level plain. Here the water leaves its banks and supplies an enormous extent of morasses, lagoons, and marshy land,

* There are abysms in many lakes where bacteria may live in slimy deposits probably far below such levels. James Murray describes a population of worms, rotifers, and crustacea at 300 feet in Loch Ness, Geographical Jourral, January 1908. 


\section{Reconquest of the Water}

interrupted only by occasional knolls of granite or other rock. The valley varies from five to fifteen miles in width, and about five hundred miles of flat marshy land has to be traversed. In the rainy season this is all flooded, and even at the driest time of the year the vegetation is rank and exuberant. ${ }^{9}$

The two plants which seem to replace Phragmites in the Nile valley are the papyrus, a giant sedge with stems often Io feet high ending in a tassel of dark green leaflets, and a grass, Vossia procera, said to be sometimes 20 feet long. But these have submerged tough and thick rhizomes (i.c. horizontal stems half submerged). When the country is flooded, as during the annual floods of the Sobat river, "floating islands," quite similar to the small patches of Phragmites but on a gigantic scale, are produced through masses of these rhizomes being detached from the mud and broken off. Such floating masses get into the main current, and at any sharp bend or curve are apt to become caught and accumulate so as to form a barrier stretching right across the river. Everything floating becomes heaped up above this barrier. Of such floating plants there are enormous quantities (such as Pistia stratiotes, Azolla, Aldrovanda); new masses of grass are for ever arriving. Some are sucked under the barrier, others pile up against it until the whole channel is thoroughly blocked by a mass of vegetable matter 4 or 5 feet or more in thickness, and extending for miles. These sudd-blocks seem to be irregular in their appearance. The army of the Emperor Nero turned back in consequence of one of them. Sir Samuel Baker found but little sudd in his first expedition, but in his second $(1870-1873)$ he had serious difficulties in cutting a channel through it. Major Peake had to cut his way through twenty-five miles of sudd in one place. ${ }^{10}$

The method adopted by Major Matthews in I9oI- 


\section{Reconquest of the Water}

I 902 was as follows: The first point is to discover the actual bed of the river, which is from I5 to 20 feet deep, and which can only be found by probing with long poles. Then the papyrus, grass stems, \&c., are cut across, and when dry set on fire. Saws are used to cut through the sudd near the edges of the river, and cross cuts are made connecting them. Then the steamer's bows are driven into one of these pieces or blocks round which a strong hawser is passed. The men stand on the ropes and the steamer goes astern, dragging out the block, which is taken down stream and let loose in the current, where it is eventually dashed to pieces on the rapids. ${ }^{11}$

The Negro savages which now inhabit these desolate marshes are hunting and fishing tribes. ${ }^{9}$ There is so little solid ground available that they cannot grow many crops : they migrate to the dry watersheds when the floods come on, and return with their cattle in the dry season.

In both the Ganges and the Amazon river, floating grass-islands are by no means unusual. There is a very remarkable similarity in the vegetation of all three rivers, and several of the floating plants are either identical or closely related forms. The grasses are, however, different, for in the Amazons it is species of Paspalum and Panicum which form the islands. Spruce measured one grass stem or rather rhizome 45 feet long and with seventy-eight "joints" on it, and with roots at each of them. Such grass-islands are uplifted from the muddy beds of the lakes, where they form great morasses, and torn off during the annual floods.

In the great province "Hylaea" of the Amazons, the river-banks are submerged for miles together and remain under water for months. The trees and shrubs of this flooded part are all peculiar species, quite different from the great forests which are never submerged. 


\section{Reconquest of the Water}

No doubt at every flood the "white" water deposits a minute film of sediment all over Hylaea, and in process of time this may perhaps become a rich and fertile pampas like that of the Argentine.

It is this last great country which is perhaps the most striking example of the geological importance of the plant world. From Buenos Ayres on the Atlantic, the express train which starts for the Pacific Coast passes over one flat, illimitable, scarcely undulating plain, until at Mendoza, some 1047 kilometres (655 miles) away, it reaches the Andine foot-hills.

The flatness and monotony of this Pampas is only perhaps really interesting at sunrise or sunset, to which the enormous horizon gives spaciousness and dignity. But even the most casual traveller is struck by its fertility. Vigorous alfalfa, rich crops of wheat and Indian corn luxuriate in a soil which is for the most part rich alluvial silt, mixed with the lime and other salts brought down from the Cordillera of the Andes.

The whole country was once the Pampean sea, whose waters extended to the eastern slopes of the Andes. Then it became a land of lagoons and morasses with sluggish silt-laden and winding rivers, and now it is the Argentine Pampas. Unfortunately there is not enough rain from the Atlantic to sufficiently supply more than the eastern edges of the Argentine, but there can be no doubt that it is all the work of plants, especially of reed-thickets and brakes of trees, such as have been described in this chapter.

The importance of this process of valley-land formation has not yet been appreciated either by geographers, geologists, or men of business. Still less have any practical steps been taken to assist or stimulate this important work. On the contrary, it is in most places delayed as much as possible by the pernicious habit of 


\section{Reconquest of the Water}

mowing down every year those very reeds and grasses which are all-important to its success.

One sees the same processes at work in every freshwater stream and in large lochs or small ponds, but not so much in polluted waters.

We should perhaps try to describe the appearance of the submerged plant world of a small loch as it would affect those weird, large-eyed crustacean larvæ or inchoate caddis-worms which browse upon the surface. This surface itself may be mud, but towards the top it is a very loosely piled up, water-saturated material. But even if the bottom consists of stones, rock, or sand, it is sure to be everywhere covered over by a shimmering indistinct mistiness of a rich golden brown colour. That is due to millions of diatoms and other minute algæ. The former are attached by transparent stalks of jelly and arranged in chains or bands, or sometimes each has its own elegant little stalk.

Crossing the water there may be perhaps the gigantic rhizome and roots of a reed or grass, or the stout cable of a water-lily leaf. Upon these grow many sorts of algæ. Some form vivid dark-green coils and festoons, waving freely in the water ; there may be twined and entangled masses of Spirogyra with its brilliant green ribbons, or the emerald star-like chloroplasts of Zygnema. Here perhaps one may find a tiny, branched Chætophora, $\frac{1}{6}$ of an inch in height with the habit of a broom ; there the great cable of a water-lily leaf is plastered over by rosettes of Coleochæte. Here may be a mass of bright clear jelly full of blue-green cells. Through the water floats majestically flaring green Desmids, which may be like crescents, rosettes, or fringed triangles. There are battalions of diatoms, also some free, others in chains or bands. At some seasons other algæ suddenly appear in myriads. 


\section{Reconquest of the Water}

But to be quite frank about this subject, the reader ought first to spend six months in careful microscopic examination of all the algæ and diatoms to be found in all the ponds and rivers in his district, then he should try to describe them, preferably in dithyrambs or leonine verses and not in plain prose.

On the shores of many of our fresh-water lakes and tarns one finds occasionally another very curious and unusual flora. The plants are submerged and consist of tiny leaf rosettes which are exceedingly like one another except when in flower, although as different botanically as they well could be. There are species of Litorella (Plantaginaceæ), Lobelia Dortmanni, Subularia (Cruciferæ), Isoetes, Heleocharis acicularis, \&c.*

These little rosettes of linear leaves are generally planted amongst stones, which as well as themselves are covered over with the usual golden-brown diatom crust, or with entangled webs of algæ.

It is said that it is specially where the waves are strong, and perhaps where the ice grinds along the shore in winter, that this Litorella association replaces reeds and marsh plants.

Along many of our Scotch rivers also, a very interesting process can be followed. The river flows between banks some 7 to ro feet high, which it has cut out of its flood plain. At the foot of these banks, certain plants are always trying to establish themselves, and especially where the water is shallow. The most prominent is Phalaris arundinacea, a grass whose tough rhizomes are tied down amongst the stones by strong anchoring roots. This grass is very important to the neighbouring proprietors, whose land is being saved by it from the constant encroachments of the current when in flood.

* Vallisneria, which is not British, is extremely similar. 


\section{Reconquest of the Water}

Willows whose branches have drifted down stream are also very useful, for by judicious planting of certain kinds the channel can be kept in its place, as indeed has been done on the Mississippi.

Unfortunately in many of our rivers the water is polluted by drainage ; in such cases one often notices the long waving locks of a green Alga Cladophora, often I 8 inches or 2 feet in length. These slimy masses are detested by the fisherman, who still infrequently catches a trout or grilse in some of these streams. After a heavy flood they seem to disappear, probably because the shingle stones rubbing against one another rub them off, but they soon grow again.

In very badly polluted streams, the whole of the bottom and everything in the water is often covered by dirty white waving tufts, which have a slimy and horrible appearance. This is a fungus, Apodya lactea, and is a sure sign of pollution. ${ }^{12}$

The Clyde below Glasgow, the Thames below London, and other city rivers are inhabited by masses of bacteria, which, however, purify the water and disappear as soon as all the organic matter has been digested by them. Such pollution is of course a waste of valuable organic matter and dangerous to mankind. It is difficult to understand how fish withstand such poisonous waters at all.

A trout was discovered a few years ago apparently trying to mount the steps at the Broomielaw in Glasgow. Some kindly person put it in a bucket of fresh water, and it was taken to the police station, where, however, it died in spite of every care and attention.

\footnotetext{
1 Webber.

2 Bonnier.

${ }^{3}$ Henslow, Freidenfeldt, Massart.

4 Wylie.

5 McCallum.

7 Friih and Schroter.

8 West.

${ }^{6}$ Oliver.

${ }^{9}$ Lyons.

10 and ${ }^{11}$ Geographical Journal, March 1900 and September 1902.

12 Turnbull.
} 


\section{CHAPTER XII}

\section{SENSE-LIFE AND SENSIBILITY}

ONE of the most fascinating and yet perhaps the most dangerous of all the many insidious temptations to which a botanist may be exposed, is that of allowing himself to speculate upon the sense-life or soul-life of the plant world.

Plants are undoubtedly alive. Animals and we ourselves can appreciate the sunlight. Sunflowers and foxgloves also mark their appreciation, and the inference that they enjoy it, just as we do, is very difficult to resist. An injured root curling itself up reminds us at once of a writhing worm, and indeed all through the phenomena of plant life one mects with instances which, unless one is very careful, lead to what Dr. Darwin describes as one of the seven deadly sins of science, "anthropomorphism."

The answer which is obvious and at first sight conclusive to all such sympathetic theories of plant life is, that plants have no nerves and cannot therefore possess either consciousness or indeed enjoyment of any kind.

But is this true either in fact or as a legitimate deduction from what we know of consciousness in the animal world?

Some years ago a very great discovery was made and, as is not unusual even with great botanical discoveries, by an Englishman. Mr. Gardiner found that the living protoplasmic cells were not, as had al ways been supposed, separated from one another by dead walls of cellulose, but that tiny minute strands of the same living proto- 


\section{Sense-Life and Sensibility}

plasmic matter crossed the walls and kept up some sort of communication between cell and cell.

These little living threads are certainly not nerves in the ordinary sense of the word, but they may function, for aught we know to the contrary, as a rudimentary nervous system. The way in which they occur, very generally in young unspecialised tissues, and in all parts of the plants, makes one inclined to suspect that this is so.

We have no knowledge as to how nerves really convey a message, and after all what are nerves but modified and highly specialised protoplasm?

No satisfactory chemical difference has yet been discovered which clearly separates vegetable and animal protoplasm. But the reader must be referred to Dr. Francis Darwin's address ${ }^{1}$ for an authoritative and yet most interesting discussion of this difficult matter.

A certain German professor, Gustave Theodor Fechner, published in 1848 a very remarkable work entitled "Nanna" or "Upon the Soul-life of Plants." A new edition has lately been produced by Kurd Lasswitz, Hamburg and Leipzig, 1908.

It is very difficult to say whether or not this work was intended to be taken quite seriously. Some of his sallies are lyrical enthusiasms which were obviously not to be understood in a purely literal sense.

Humour takes very strange forms at times, and this is especially true of its German equivalent. Some of Fechner's critics, and especially Schrammen, ${ }^{3}$ have perhaps taken the eloquence of Fechner much too critically and seriously.

It is full of blunders, "howlers" of the most distressing character, as, for example, when he compares the spirally wound threads in some stem-vessels to the nerves of animals.

As he says in another place: "The plant is ever the I 4 I 


\section{Sense-Life and Sensibility}

woman confined to her narrow home circle, whilst the free man (the animal) has to struggle for himself in the world. The flower talks to her lady neighbours in perfumes; provides nourishment for the animal, bakes bread and prepares vegetables for him. Her dearest business is, however, at the time of flowering, when she clothes herself beautifully, and in new and lovely apparel. But, when the days of young love are over, she throws aside her gay colours and frivolous stage (Flitterstaat), and her first and only thoughts are directed to the care of her young children" (l.c., p. 262). ${ }^{2}$

The above translation is extremely free, but in truth any literal interpretation would be too comic, and would not give the reader any just idea of what is really a very eloquent and interesting book.

"Is it not absurd that a breadfruit with its thousand years of age, huge growth of stem and branches, vigorous development and carefully elaborate internal mechanism, should stand lower in the scale of creation than the minute rough little Polyp formed of the ruclest material, or the still more delicate Infusorian, which after the briefest term of life is promptly returned to the slime out of which it has just been fashioned."

In plants we see that the ascent of sap, the complex working up of food material, respiration and nourishment are all actively at work. Why should nerves be necessary if it is to have consciousness when it can carry on all these complex processes without them?

Has it soul-strivings in its growth towards the light? Are we conscious of our own growth, over which we have no control whatever?

In another specially notable passage he complains that the world would be but a solitary place if plants possess no souls, for emotion would be but sparingly scattered over its surface. 


\section{Sense-Life and Sensibility}

"God surely collects into one concert of harmony the emotions and sensations of all living creatures, and how far apart and separate would be the living instrumentalists if the whole plant world were excluded from participation therein. Think of a forest through which a roebuck, and that at very rare intervals, sometimes passes on its solitary way!"

There can be but one opinion as to the beauty of these ideas, but most botanists, and especially Schrammen, may not at first perceive that there is an argument, and one of some cogency, underlying their fantastic idealism.

For it is a fact that protoplasm, in plants and animals alike, breathes or respires, works, becomes fatigued, and eventually clies. What authority have we for the statement that consciousness is dependent on the possession of a nervous system ? Is it not an essential condition of protoplasmic life that it can do things of itself and does them on purpose? However, the reader must be referred to Fechner's "Nanna" for further details, in which he will find much that is of great interest.

There is also on this subject a recent work by Maeterlinck, ${ }^{4}$ whose attitude can be at once understood from the following striking passage :-

"I shall never forget the admirable example of heroism exhibited by an enormous centenarian laurel, which I found the other day in those wild yet charming gorges of the river Loup in Provence. One could read without any difficulty the whole drama of its stubborn and difficult life clearly written on every line of its strained and almost tortured (pour ainsi dire convulsif) trunk. Some bird or perhaps the wind had deposited the seed on a bare rock which fell straight downwards below it like an iron curtain. The tree was born there 200 yards above the torrent bed, inaccessible and solitary amongst barren and sun-scorched stones. 


\section{Sense-Life and Sensibility}

"From its earliest moments it had had to send out its blind rootlets on a long and difficult search for a precarious supply of water and of leaf-mould. But that is just the usual hereditary task which falls to the lot of this species, and which too well understands the arid nature of the Midi (South of France).

"Its young stem had to solve a problem much more serious and unexpected. It had left the vertical position, so that its head, instead of rising up towards the heavens, inclined over the ravine. It was then obliged, in spite of the growing weight of its branches, to change its first intentions and curve backwards towards the smooth rock surface, where its disconcerted stem had to maintain itself like a swimmer who throws his head back, and so, upright towards the heavens, sustain by its own determination the stresses and incessant strains due to its heavy crown of foliage.

"Moreover, upon this vital complex had been concentrated all the preoccupation, all the free and intelligent genius of the tree.

"The enormous elbow-like hypertrophied curve of its stem revealed one after another the successive anxieties of a kind of reasoning that knew how to profit by the warnings that rain and storm had given.

"Year after year as the heavy dome of foliage increased in weight, without any care save that of expanding in the warmth of the sunlight, there was all the time an obscure canker corroding deeply the great basal arm which held it up.

"Then in obedience to some instinct of a quite unknown character, two solid roots, two knotted cables springing from the trunk more than 2 feet above the band, had managed to fasten the tree to the granite face."

In this passage, as in the whole of the essay referred to, the author simply endows plants with reason and 


\section{Sense-Life and Sensibility}

intelligence. Striking as are many of the purposeful adaptations to be found in plant life, such an assumption cannot possibly be maintained.

But it is necessary to abandon speculation and try to show how much of more recent work tends to explain this difficult question of the purposeful working of plant protoplasm.

There is first the extraordinary sensitiveness of both leaves, stems, and petioles to sunlight. According to Darwin, grass seedling will curve towards a source of light so faint that it is indistinguishable to a human eye. The careful experiments of Haberlandt have shown that not only the leaf blade but even its stalk are so affected by sunlight that both move and so arrange or display the green surface to the best advantage. One plant, Fittonia, has a tiny cell the shape of a biconvex lens placed at the top of prominent epidermis cells. ${ }^{5}$

That this acts like a lens scarcely admits of any doubt, and it will focus the light upon some particular layer inside the leaf. Should this focus be a sensitive protoplasm-surface which will react to light, then one can see that the leaf may, by the reactions of this protoplasm, shift its position until it is at the most desirable angle for illumination.

These peculiar, lens-like cells have been compared to the primitive simple eyes found amongst many of the lower animals.

That they do act like lenses scarcely admits of any doubt, for Haberlandt and others have made photographs by means of these epidermis cells. Mr. Harold Wager exhibited at the Linnean Society, I gth Nov. I908, several excellent photographs of flowers, landscapes, houses, and even of figures taken by means of these epidermis cells. Even autochrome plates (Lumière's) were used by him. ${ }^{6}$ When, as in some of Haberlandt's 


\section{Sense-Life and Sensibility}

examples, the light rays are focussed on the lower or floor-walls of the epidermis, they will produce a difference in the illumination of the protoplasm there, and, on his theory, this difference is the protoplasm-stimulus which results in the leaf taking up a proper light position.

Each individual cell will move until it is in the right light position. There is a difficulty, however, in distinguishing between light as producing protoplasm movement and light as producing assimilation, but the close resemblance between the primitive eyes of animals and these epidermis cell eyes of plants inclines one to Haberlandt's theory. ${ }^{7}$ If one could believe, without misgivings, that the older leaves of Hæmanthus do really twist sideways so as to allow of a better light position for the younger ones, then one needs no further proof of reason and morality in the plant world, but some confirmation is acquired of these observations. ${ }^{8}$

Young growing roots, stems, and leaves are very sensitive to the earth's attraction or gravity (that is, they are geotropic). In a general way, stems grow up and roots downwards, whilst many runners and underground stems grow horizontally. One of the most remarkable cases is that of the underground rhizome of Solomon's seal which prefers to grow at a definite depth below the surface of the soil. If it is planted too deep, it will grow in a slanting way upwards till it reaches this favoured depth, and will then grow horizontally. If it is placed too near the surface it turns downwards till it gets to its proper level.

This remarkable behaviour depends upon two reactions. The upright foliage and flowering shoot, which is a bud springing from the rhizome, seems to perceive the light stimulus, and as soon as it pierces through the soil, the upward growth of the rhizome stops.

The rhizome itself is influenced by gravity in such I 46 


\section{Sense-Life and Sensibility}

a way that it grows horizontally at right angles to the force of gravity. ${ }^{9}$ So guided by light and gravity, the Solomon's seal discovers the precise depth at which it is adapted to grow. It must be remembered that such stimuli as these are not necessarily motive forces. They may be used like the mariner's compass which guides a ship across the ocean, and need not be compared to the steam which drives its engines.

It has been found by careful and minute investigation that in those parts of plants which show themselves sensitive to the action of gravity, there are almost always numbers of small starch grains called statoliths. Suppose that in the cells of a root the protoplasm is only "happy" when these starch grains are resting on the lowest wall or floor of the cell. If the root is supposed to be tilted sideways, then the grains will drop into a corner of the cell. The protoplasm is supposed to react to this uncomfortable condition, and by the growth of the cell or movements of the cell contents bring the cell back into the right position. To do this the root turns or grows downwards.

The similarity of this reaction to that of the otoliths in the ears of the higher animals is very remarkable, and in spite of the complex nature of the whole proceeding most recent authorities seem to believe that it is by the tumbling about of these starch-grains on a sensitive protoplasmic layer that both stems and roots react to gravity.

Some of the evidence is very strong. Thus in the roots of parasites, and in those of certain arums, willows, and other water plants which do not show the usual downward growth, there are no such statoliths. ${ }^{10}$ In some grasses (Festuca sp. and Poa sp.) the seedlings show at first no geotropy, but when they are mature there is a marked reaction. In those roots the starch 


\section{Sense-Life and Sensibility}

grains are at first irregular, but become regular and like statoliths when the older stage is reached. ${ }^{11}$ On the other hand, when there is a marked reaction, all, with very few exceptions, who have looked for statoliths, seem to have discovered them.

The curvature due to gravity occurs rapidly enough, for in about two-thirds of a second to a second the root begins to curve. ${ }^{12}$

The sensitiveness of tendrils and of young roots to touch or contact is unmistakable. Something of the same nature is found in submerged roots and leaves when growing in the rapid current of a river or stream. This sort of "tact" is certainly due to some sort of "distress" of the protoplasm in the cells affected, at least there is a hazy sort of idea that it is due to the injury or suppression of growth of the cells immediately affected; no real explanation has as yet been offered. Darwin's passion-flower and other tendrils, which curve at once when gently stroked, are the classical examples of this reaction. Its use is obvious, and especially in the case of roots which have to (so to speak) feel their way in and out amongst sharp-edged stones and curving passages in the soil.

But a still more remarkable and impressive example of sensitiveness to touch is afforded by the stamens of the Barberry, of Mahonia, of some species of Centaurea, and of other plants. The sudden jump inwards of the Barberry stamens, whilst the pollen is simultaneously thrown out of its open pore, is one of the most wonderful contrivances for pollination in the whole range of flower structure.

Until recently it was supposed that the movement was due to some sudden change in the water contents of the epidermis cells. But Professor Heckel made an extremely difficult operation on the Mahonia stamens 


\section{Sense-Life and Sensibility}

which cannot be reconciled with that theory. $\mathrm{He}$ used a knife with a triangular point similar to that used by oculists in operations for cataract, and by means of it removed the whole epidermis of a Mahonia stamen without even detaching it from the flower. ${ }^{13}$ As these skinned stamens still moved when touched, it is clear that more than the epidermis is concerned. As M. Dop found that such stamens on movement showed the same electrical reaction that occur when animal muscle contracts, it is more probable that it is the protoplasm which contracts or is in some way "distressed" on stimulation. ${ }^{14}$

Another remarkable power of plant protoplasm is chemotropism, or the recognition of different substances which may attract or repel motile plants such as bacteria or spores. One may compare this to "taste" in the higher animals (not of course literally). One interesting experiment is as follows: a quantity of the actively moving male cells or antherozoids of both a moss and a fern are placed in water and then two vaccine tubes are introduced, filled, the one with a weak solution of cane-sugar and the other with malic acid. The moss sperm cells will collect in the cane-sugar and those of the fern in the malic acid. But if these solutions are too strong, the sperm cells not only refuse to be attracted but are actually repulsed and swim away from them. ${ }^{15}$

Bacilli can detect and react to .oor per cent. solutions of certain salts, concentrations so weak, that is to say, that no human being could detect them. Some other very interesting comparisons of their tasting powers have been described by the same author. ${ }^{16}$ Nor is this power confined to moving spores of algæ and to bacteria. Roots show the same power of turning towards or away from certain substances. Roots of Leguminosæ will, for instance, turn and grow towards phosphates, but 


\section{Sense-Life and Sensibility}

they will turn away from poisonous substances. Not only so, but they are attracted by small quantities of certain salts, and are repulsed and grow away from large amounts of the same substances. When in excess even nutritive solutions are or might be poisonous. ${ }^{17}$

But strange as are these fitting reactions of vegetable protoplasm, those exhibited by such plants as the sundew, pitcher-plant, and the like are infinitely more remarkable.

It is unnecessary to describe how the tentacles of the sundew turn and pin down the unfortunate insect which has alighted upon it, for this has often been done. But one should mention here that small grains of sand, bits of wood, paper, or glass particles produce no secretion of the glands. Small pieces of meat, egg-albumin, \&c., on the other hand, are soon surrounded with secretion, and will be absorbed in some fifteen minutes. The liquid in a Nepenthes pitcher is of great importance, for a fly laid in a pitcher that has been emptied of its water is very slightly affected even after four hours. But if you dip the insect in the fluid of another pitcher and then lay it in the dry one, there is an abundant flow of secretion, and nothing will be left of the fly except insoluble chitin in six to eight hours' time. ${ }^{18}$

These facts are surely very remarkable. The reader must be left to draw his own conclusions as to whether it is fair to say that plants are senseless automata, mere complex mechanisms unable to enjoy the sunshine and the sweetness of life.

They are certainly for the most part not guilty of senseless and useless cruelty, except perhaps certain Asclepiads, and notably Araujia sericifera, which grows at Buenos Ayres.

This evil plant has a sweet vanilla perfume which attracts numbers of butterflies. But when they attempt 


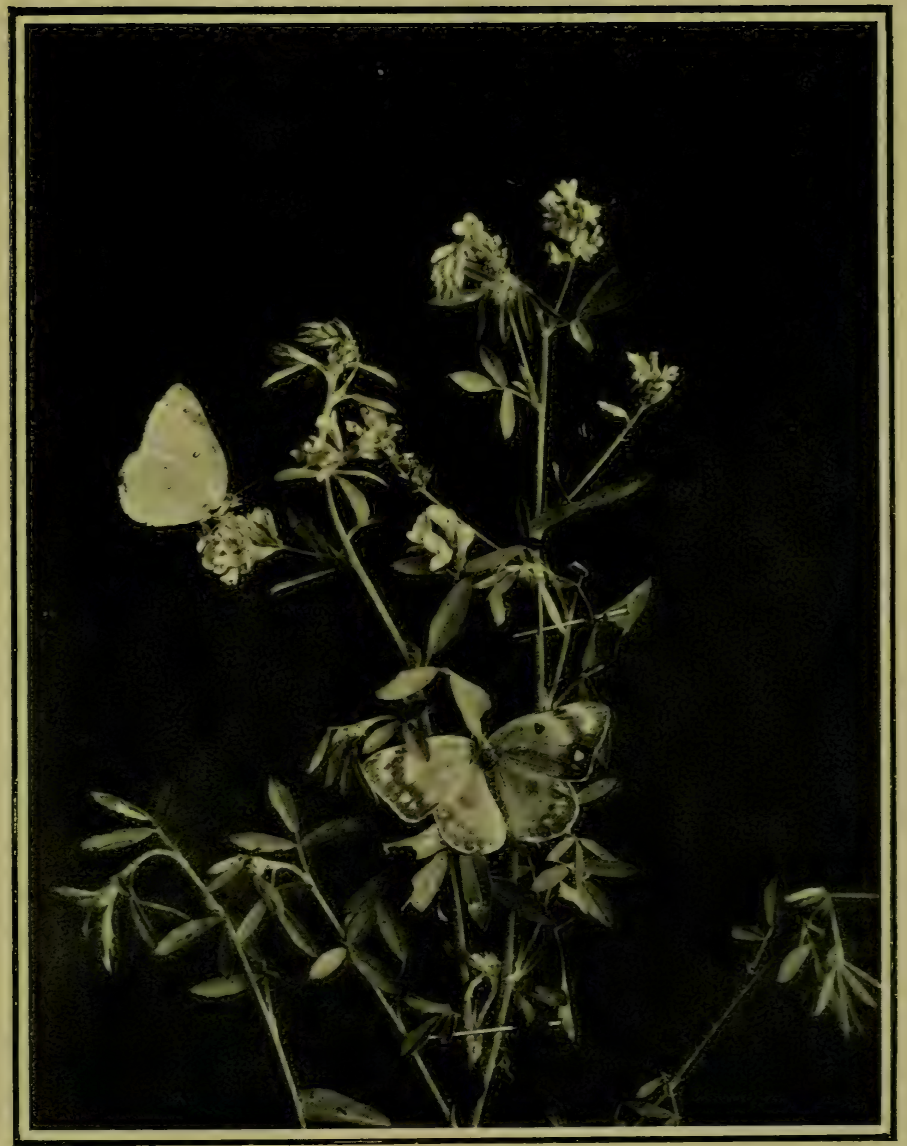

Stereo Copyright, Underwood \& U.]

[Londont and New York

\section{ALFALFA}

Showing the butterfly that visits the flowers regularly. Alfalfa produces from five to ten crops a year, and is perhaps the most productive of all forage crops. It is a variety of the English lucerne. 



\section{Sense-Life and Sensibility}

to suck the honey, their proboscis get inextricably caught in the flower, and they perish miserably. M. Kunckel d'Herculais tried hard but could not help them to get free; the only result of his well-meant efforts was to decapitate the hapless insects. ${ }^{19}$

There is also a well-known orchid which has a hinged lip. When the unsuspecting insect enters the flower and passes over the lip, it is suddenly jerked forward and thrown into a sort of bath of liquid ; as it painfully crawls out, with wetted wings, it has to carry away the pollen masses and so effect pollination. There is no cruelty in this, for the insect is supposed to visit another flower and cannot be much harmed.

There are certain flowers whose honey intoxicates the bees, who may often be seen, quite drunk and incapable, crawling about the ground below them. But this is a business matter, for the bees are intended to get a taste for this particular kind of honey and so benefit the plant. No doubt, in time, they will discover how to enjoy it without injuring themselves, much as, according to Dr. Archdall Reid, intemperance will inevitably work out its own cure amongst human beings.

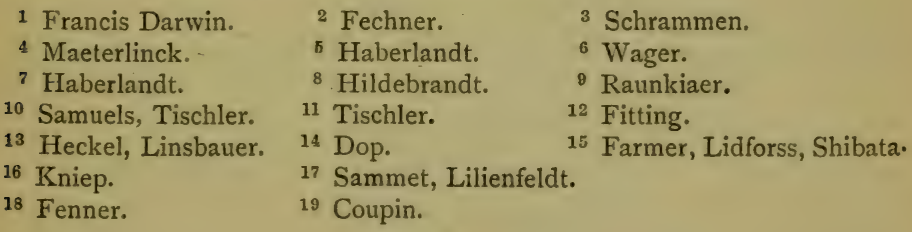




\section{CHAPTER XIII}

\section{THE INDIVIDUAL PLANT}

In the last chapter, when referring to the sense-life of plants, we intentionally left out of consideration a difficult little question which ought to be mentioned.

Our own bodies, and those of all animals with a concentrated nervous system, are so controlled by our will that we always think of ourselves and animals as individuals. We transfer this idea to the higher plants, who to us seem individuals also, but as a matter of fact in them there is, so far as we know, no concentrated nervous system, and neither brain nor will power.

The various cells which make up a plant are neither entirely free nor are they without individuality of their own. Some very interesting cases have been lately described in which one almost seems to see the plant rigorously sacrificing some of its members for the benefit of the survivors.

The youngest leaves or shoots are those which are least specialised, and in which it seems the protoplasm is least exhausted. They have more adaptability, being able to suit themselves more readily to changes in climate or soil conditions, or to differences in the supply of moisture or sunlight. Old leaves, on the other hand, are not so well able to withstand sudden and unusual changes in temperature, long periods of drought or of darkness. ${ }^{1}$ This principle must not be carried too far, but perhaps explains the following curious observation.

When plants are withering or drying up the water is often withdrawn from the older leaves and stems, and concentrated in the young growing parts. 


\section{The Individual Plant}

One often sees this, e.g., in herbarium specimens which are being dried. Even in spite of heavy weights upon the blotting-paper, fresh whitey-yellow buds are put out by the younger parts of a Sedum or Sempervivum, and a little anæmic-looking shoot goes on growing, whilst the older leaves and stem are dead and rapidly drying up. But this occurs in other plants also. When Elder, Philadelphus, and Robinia branches are allowed to wither, they will keep the younger branches and leaves fresh and green, sacrificing the older leaves, which soon die and drop off. An Ipomøa, for instance, flowered during this process of withering. ${ }^{2}$

In such a case, however, it is most probably the keen competition between the thirsty leaves for water that results in the weaker ones being killed by thirst.

Suppose that a leaf is injured by, e.g., an insect such as the roseleaf wasp, which cuts out of it a little circle of leaf tissue, then clearly there is a danger in the open circular wound. The loss of water by evaporation might very soon dry up the leaf, and what is even more perilous, one of the many dangerous fungus spores might attack the freshly exposed inner tissue and destroy not only the leaf but possibly the whole tree, for the poisonous secretions of such a fungus would very likely pervade the entire plant. But leaves are well able to deal with such an emergency as a cut or bruise.

Immediately this happens, the living cells, some little way in from the wound, begin to divide and form a peculiar mass of cork-like tissue filling the space between the epidermis of the upper surface and that of the lower. Everything outside this cork-like layer dies, because, of course, neither water nor food material can pass through its closely set cells. So by a kind of surgical operation the dead and injured part is cut out and soon withers and drops off.

Professor Blackman and Miss Matthaei made many 


\section{The Individual Plant}

experiments to trace this process of self-surgery. Leaves were cut in various ways or pieces punched out of them, and sometimes they were only bruised at one point. ${ }^{3}$

In many cases, everything outside the injured tissue was deliberately sacrificed, the living protoplasm acting like an army whose outpost line has been suddenly surprised, and which deliberately abandons its advanced posts and entrenches itself behind a new layer of improvised cork cells. Something of the same sort happens regularly before the fall of the leaves in autumn. Not only a cork scar is formed across the bases of the leaf stalks, but a special separation layer is formed outside the cork, and the deacl leaf drops away from the clean, corked-in scar. Many curious cases, in which injured or worn out parts of the stem itself have been deliberately cut off by cork scars and thrown away, have also been described. ${ }^{4}$ There are other well-known cases in which one is much impressed by the readiness for any emergency of every live cell in the plant body.

In the stem of Liquidambar (or Balsam of Tolu), for instance, the younger wood cells will be peacefully performing their usual duty of assisting to raise the sap or of filling themselves with temporary stores of starch or other reserve food material. A sudden emergency arises, for some one has made a deep cut or slash through the bark and into the young growing wood tissue.

The cells at once begin to secrete resin, which at first fills the intercellular spaces, forming small canals or ducts ; then the cells begin to break down, and a network of such resin canals is formed, which pours an abundance of secretion over the wounded surface, completely covering it over and sealing it up. Other cells, in the cortex, at once begin to make a cork cushion, which gradually and slowly grows inward over the wound. ${ }^{5}$

The future of and the claims upon every living cell between the dead outside cork and the dead heart wood 


\section{The Individual Plant}

within have been radically altered. They are suddenly called upon to respond to a very unlikely emergency, and they rise or rather expand and divide to the occasion.

Amongst the many triumphs in fossil botany, there is the discovery from microscopic sections of fossil Brachyphyllum stems, that this plant also healed its wounds in the Jurassic Age by means of resin secretions. ${ }^{6}$

Dr. Nemec's important work on Regeneration ${ }^{7}$ (published in $1905,360 \mathrm{pp}$.) has called attention to another series of facts of a strange and interesting character, and which reveal the same readiness of vegetable cells to undertake any work required of them.

One would think that the beheading of the growing point of a stem or root would be an irreparable damage. But that is by no means the case! A decapitated root at once begins to form a new root tip. The living cells behind the cut surface form a temporary or provisional root cap, and then an arched or dome-like mass of young growing cells on which a new growing point is formed.

Not only so, but if the root tip is only half cut across, the cells behind it at once begin to form a new growing point, and the old injured one is ruthlessly sacrificed, being separated off by a layer of easily detached cells. ${ }^{8}$

This reminds one of those worms which when decapitated can form a new head.

In the case of some ferns (Adiantum sp.), the leafgrowing point may be directly changed into a stem, or runner growing-point.? But what is perhaps still more remarkable is the manner in which cut off leaves may take root and produce a whole plant with roots, stems, leaves, and flowers. ${ }^{10}$ In the case of Torenia, if a leaf is cut off and laid on moist earth, buds appear all along the leaf and indeed almost anywhere.

These buds at once begin to grow, each forming a stem and small leaves (the growing tissue is the epi- 


\section{The Individual Plant}

dermis of the original leaf). The strongest of them soon gets ahead and promptly flowers and seeds.

The fortunate one is usually near the leaf stalk, but any of them may succeed in surviving.

There is of course a want of order about these proceedings, but the orderly nature of plant life has been upset, and one should rather admire the readiness to save the situation, than blame the want of discipline exhibited by the competitors.

Such an instance as this is very difficult to explain on Weissmann's theory of a special germ plasma, which can alone reproduce a new plant, for the leaf has improvised not one but several potential germ plasmas.

Moreover internodes (for instance, of Ceropegia Woodii), when separated or cut away from the parent plant, can produce tubers and eventually flower. Root cuttings are by no means unusual, and give rise to quite normal plants.

It is very hard to believe then in the existence of an "immortal" germ plasma in any way separated from ordinary protoplasm, though of course the protoplasm of pollen grain and egg cells differs from that found in ordinary cells (compare Darwin). ${ }^{11}$

Competition can be clearly distinguished amongst the twigs of a tree, all of which seek the light.

The same struggle goes on between the twigs on one branch, or the leaves on one twig, and even to some extent between the flowers of one inflorescence. It is surely true that every cell in the plant is also competing with its neighbours for water nourishment, oxygen and the like. This has been long insisted upon by Rolf and others, but seems never to have been quite appreciated.

\footnotetext{
1 Hansgirg.

4 Mahew et Combes.

7 and ${ }^{8}$ Nemec.

2 Pringsheim.

${ }^{5}$ Svendsen.

${ }^{9}$ Kupper.

3 Blackman and Matthaei.

${ }^{6}$ Jeffrey.

10 Winkler, Figdor.

11 Darwin.
} 


\section{CHAPTER XIV}

\section{SEASIDES AND STRAND PLANTS}

MANY peculiarities and conditions of plant life depend upon the way in which the world is worked, that is, upon certain laws which are universally true, yet quite of a simple and obvious character.

Winds carrying water from the sea will travel far inland, raining in a mild and benignant manner upon lowland valleys and plateaux, but expending the whole of their energy in furious deluges whenever any conveniently situated mountain range forces them to rise into a cooler atmosphere. On these highlands, rain forests or peat mosses collect and retain the water, but allow it to escape only gradually. The mountain streams carry down peat, silurian and indeed every kind of geological particle, so that their silt, by the time most of it is spread out flat in the valley lands and holms, is of great fertilising value. But in the end, such rivers still full of sediment pass out to sea and become disturbed and mixed up with erratic shore currents and changing tides.

When the fresh and salt water meet, especially when its motion is checked, as often happens, the silt falls as sediment. It is in this way that are formed the great shifting banks of mud and of sand, which occupy miles of our estuaries and extend far out to sea.

At low tide, though only but a small proportion are exposed, there are hundreds or thousands of acres of these gently curved banks, intersected by intricate and capricious channels, continually altered or newly formed by the river and tides. 


\section{Seasides and Strand Plants}

Those near shore are already occupied by a short sward of vegetation. These are quite flat, often very wide in extent, and are definitely conquered and being utilised by the plant world.

We shall call them the Armeria mud-flats, for in early summer they are quite beautiful with the exquisite pink flowers of the seathrift or Armeria.

If one proceeds towards the water, one finds, after a greater or less interval, that Armeria and most of its companions suddenly disappear. At first one might think that there are no more land plants, but towards the sea the undulating surfaces of the highest banks are covered with a faint light-green tint.

When, after some difficulty, such a place is reached, ones finds distantly scattered over the surface multitudes of a small but most interesting plant, the saltwort (Salicornia herbacea). But in the estuary there is still another land-vegetation-the submerged seagrass meadows of Zostera and its allies, Ruppia and Zannichellia.

These three associations-submerged sea-grass meadows, saltwort banks, and Armeria flats-are engaged in the same task which is to occupy the estuarine mudand sand-banks, and turn them into good and fertile land.

Zostera and its allies are to be found chiefly about low-water mark, though they go to considerable depths (9, I5, or even 35 feet below the water). In such places they require very special contrivances, both to keep themselves anchored and also for pollination.

Zostera stems are prostrate, curved, and firmly held by roots alternately placed on either side and directed sideways. During a tug-of-war (if one is calm enough in spirit) one sees the rope becoming inevitably curved by the men at the loose end throwing themselves back, whilst the part held by the first two or three men is 


\section{Seasides and Strand Plants}

nearly horizontal; the men also tend to form an acute angle with the rope. The stem and roots of Zostera has a curious similarity to the tug-of-war rope, and one sees at once how well it is adapted to hold its place.

All along the stem, at every I or 2 inches, are the flattish, grass-like leaves which may be 3 feet long, and are kept upright and waving in the water. These leaves have a water-pore at the tip (presumably to keep up the circulation of food material), but are without the stomata characteristic of ordinary leaves.

The flowers consist of one stamen and one carpel, and about twelve of them are enclosed in a protective sheath.

When ripe, the pollen is discharged into the water. The whitish pollen grains resemble tiny worms about $3 \mathrm{~mm}$. long $\left(\frac{3}{25}\right.$ th inch ; the length is about 250 times the breadth), and are unlike any other pollen grains. Being of the same specific gravity as sea-water, they float freely about; should they happen to touch the long stigmatic surface of a carpel, they wrap themselves spirally round it and so effect fertilisation. The fruit is supposed to be eaten by fish. If so, Zostera marina has been successful enough, for it is found from the Mediterranean to the Baltic, in North America (Atlantic and Pacific Coasts), and in China and Japan. ${ }^{1}$

These submerged meadows are of some importance, for they tend to prevent the continual shifting of the sand-and mud-banks, which of course is the first step in the formation of new land. How far they succeed in doing this has not as yet been discovered.

When, however, such banks have been fixed in position and so raised by deposited silt that they are distinctly exposed at low water, a new development begins.

Amongst the floating rubbish carried back and forward by the changing tides are certain round fleshy little bodies bearing minute flowers and fruits. 


\section{Seasides and Strand Plants}

These are the joints of Salicornia herbacea, the saltwort or marsh samphire, whose seeds germinate in saltwater (indeed they are more healthy in it than in fresh), and whilst still attached to the buoyant, cigarshaped joint.*

One of these seedling plants grounds in the salt mud on the top of the bank, and its roots at once grow vigorously, and very soon a small independent plant has established itself. Others no doubt accompany it, and the surface of the bank is soon overspread with this remarkable plant. It is extremely like a miniature cactus, and this succulence seems inexplicable, for why should it resemble a desert plant when it has water everywhere, and indeed is daily submerged at high tide?

But the water is salt, and common salt is really a poison to vegetable protoplasm. The Salicornia, however, has adapted itself to these conditions; it can alter the density of its internal cell sap and so regulate the amount of water taken in. ${ }^{3}$ It has been found that the protoplasm of its root-hairs is healthy in so concentrated a solution as 5.8 per cent. of common salt. If, however, the root-hairs are left for two hours in I per cent. solution, and then suddenly transferred to a 5.8 solution, the protoplasm shrinks together (or is plasmolysed). ${ }^{4}$

This little experiment shows that it is able to regulate the density of its cell sap according to the saltness of the water, and so explains how it has been able to adapt itself to these dangerous conditions.

One might compare its behaviour to that of people who accustom themselves to the eating of arsenic, and gradually become so trained to the poison that indeed they can hardly do without it.

* Dr. Guppy ${ }^{2}$ found joints with fruits and apparently germinating seedlings off the coast of Peru. The seedlings in salt-water can live for some ten weeks but then die if they cannot attach thenselves to salt mud. 


\section{Seasides and Strand Plants}

The cactus has next to no water and the saltwort poisonous water, so that in both cases they modify themselves and take in as little as possible.

The author cannot say that the saltwort is able to grow vigorously enough to be of much importance in the way of collecting or straining out of the floods any floating rubbish. Professor Flahault has very carefully described the behaviour of an allied species (S. macrostachys). This is of a more branching habit, and grows on the tide-swept beaches of the Camargue in the South of France. Sand gathers round it as well as leaf-mould and rubbish ; other mud plants manage to grow amongst its branches, and so the settlement of one Salicornia macrostachya may become a tuft 2 to 3 feet in diameter. By the gradual coalescing of such tufts the area of inhabited country gradually extends seawards. ${ }^{5}$

The author has never been able to trace anything of this kind in Britain, but of course the level of such sandbanks is always rising by the continual deposit of silt and sand at high tide.

The colonisation seems (in the Solway) to advance outwards from the Armeria mudflats, and it is a grass, Glyceria maritima, which seems the really important plant. Its long trailing branches grow outwards lying on the sand or mud, and root if they have the chance to do so.

Thus it extends into and annexes the territory of the saltwort, which occurs between and amongst the Glyceria. At this stage the occupation is still very scanty but then goes more rapidly onwards, for any silt or floating material will be strained out of the water as the tide oozes out.

Very soon Armeria itself as well as Triglochin and Plantago maritima, Aster Tripolium (in some places also Spergularia marina and Glaux) begin to form the typical Armeria flat. 


\section{Seasides and Strand Plants}

Most of these plants have smooth, more or less succulent leaves, for like Salicornia they have to endure from .04 to nearly 5 per cent. of salt water. ${ }^{4}$ Now several experimenters have directly produced fleshy leaves, quite of this character, by supplying, for instance, garden wallflowers with salt instead of fresh water. ${ }^{6}$

So that this fleshiness seems to be a fitting reaction caused by the salt, and also helping the plant to resist its poisonous effect by living in a thirsty sort of way.

Such Armeria flats vary considerably. On the Clyde one may find exquisite dark green mats of the Alga Vaucheria filling up the interstices between the other plants, and firmly attached to the dark mud by hundreds of rhizoids. The elastic strength of such a Vaucheria cushion is very remarkable, as one can see by cutting out a square foot and holding it up by one corner. Such fat, dark soil as one finds along the Clyde is probably full of organic matter, but it is kept well aerated by various small worms. There may be as many as fifteen of their burrows in a square inch of surface.

Cattle and sheep browse at low tide upon the Armeria flats, where indeed they grow fat and flourish exceedingly.

But on the landward side, where the salt is being gradually drained out, and where the level of the soil has so much increased in height that even the highest tides but rarely extend to it, a new process is beginning.

Rushes (J. lamprocarpus), sedges, and a few grasses (Agrostis, Festuca alba var. stolonifera) are beginning to encroach upon the Armeria country, and if they once succeed in getting a root-hold, other weeds come in (couchgrass, cock's-foot, Yorkshire fog, bird's-foot trefoil, white clover, silverweed, and Crepis virens), and it is soon a seaside meadow. It is difficult to trace the later stages, for by the time that some of these weeds have effected I 62 


\section{Seasides and Strand Plants}

a lodgment, the land will probably be enclosed and form part of the ordinary farm lands.

The conditions vary greatly along such an estuary, for sometimes the sea is encroaching, and near freshwater streams comparatively deep water may be found close inshore. There are a whole series of plants which are adapted to these varying conditions. There are estuarine reed-beds of Scirpus Tabernæmontani which act like Phragmites (see p. I30). But its stems are firmly fastened down by strong anchoring roots. In such a reed-bed one may count forty to fifty upright stalks in a square foot of surface, so that they will efficiently strain out of the water floating rubbish of every description. Such a bed may advance about 9 inches seawards in a year, and is attacked on the land side by Armeria, Aster, scurvygrass, as well as by Vaucheria, Ectocarpus, and other Algæ. So it changes into an Armeria flat or directly into a grass meadow.

On the La Plata river one finds quite similar arrangements for colonisation by Scirpus montevidensis, which grows in I or 2 feet of water, and in shallower water Eleocharis bonariensis forms a close, grass-like sward which is colonised by a Hydrocotyle and Spilanthes stolonifera.

In South America, also, seashore mud is sometimes artificially reclaimed by means of a grass, Spartina brasiliensis, which is planted out in rows at depths of I foot below the surface. ${ }^{\text {? }}$

Lord Montagu de Beaulieu has stated that many acres of the mud in Southampton Water has been naturally reclaimed by the British species of Spartina; but, so far as the author knows, no attempt has been made at plantation in this country. Such estuaries form, however, but a small part of the coast-line. The great stretches of shingle which are for ever travelling 


\section{Seasides and Strand Plants}

along the shore are practically not colonisable until they accumulate and become stationary. Then they are rapidly overgrown by a miscellaneous series of plants of which most are common weeds. But on such shingles one may find the yellow flowers and long pods of horned poppy (Glaucium luteum), or the particularly spiny rose (Rosa spinosissima), and many of the characteristic sand plants. These last are scattered along the shore just above high-water mark, and would seem to be growing in pure sand, but generally they are rooted in buried seaweed or drift rubbish only covered over by the sand.

These sand plants are all adapted to very dry conditions, as one would expect, and include Glaux, Honckenya, Isle-of-Man cabbage, various Atriplex sp., Samolus Valerandi, \&c., and many rare plants are to be looked for in the more sheltered places. But the theory of the plant world in dealing with sand can only be gathered from a series of dunes. On a very windy day, any one watching a sand-dune can scarcely believe that any plant could possibly deal with it. Not only is the soil thoroughly bad, for it is full of salt, very loose, porous, and exceedingly dry, but at mid-day the sunny side of a dune may show a temperature of $80^{\circ} \mathrm{C}$., whilst at night the radiation of heat will be exceedingly rapid and cool the surface far below that of normal soils. The worst point, however, is that it is not fixed but always shifting. In storms, sprays and showers of small sand particles are torn off by the wind. Much of the dust consists of angular flinty particles which, when blown by a gale, can polish and wear down the very hardest rocks. The dune itself moves, for the larger particles are drifted up the long seaward slope and tumbled over the crest.

Yet, except in a few rare and exceptional instances, plants do annex and colonise sand-dunes. 


\section{Seasides and Strand Plants}

Close to the sea and outside the sandhills a certain grass (Agropyrum junceum) manages to exist in spite of the salt and extreme exposure. It has long underground runners, and very hard stems and leaves coated with a bluish-green, waxy excretion. Against its sturdy stems and those of Honckenya, Cakile, and other sand plants, the blown sand collects and piles up into low hillocks * or small heaps of sand.

These small mounds are then attacked by the bentgrass (Psamma arenaria), which is the real specialist in sand-dune colonisation. The underground stems are very long and wiry, whilst its leaves are tough and flexible, able to resist the strongest gales or the still more dangerous friction of the flinty sand particles which are carried by it. Suppose Psamma is buried under 20 feet of sand by the movement of a dune, it simply grows up to the light without being at all injured. The growing points with their fine sharp points are particularly designed, especially to pierce through such overlying sand.

Now the windy or seaward slope of a dune may be at a gradient of some $5^{\circ}$ to $10^{\circ}$, whilst the lee slope where the sand-grains, having been carried over, lie at their angle of rest, may be at an angle of about $30^{\circ}$ to the horizon.

Psamma, however, interferes with this mathematical regularity by establishing itself especially about the crest of the dune, where its strong bunches of hardy leaves act as a sort of breakwater. The whole sandhill is soon traversed and more or less tied together by its rhizomes and roots.

So the hollow behind the crest becomes gradually filled up by whatever sand passes over, and is soon plentifully colonised by vigorous tussocks of Psamma.

* Such hillocks are about I to 3 feet high. Reinke ${ }^{8}$ gives 6 to 9 feet, hut this is surely very unusual. 


\section{Seasides and Strand Plants}

These tufts are still separated by intervals of bare sand, but as soon as the dune ceases to move perceptibly other plants begin to appear.

Just behind the crest one finds the sea-holly, Eryngium, which has a complicated, auger-like bud well fitted to bore its way through the sand. Bird's-foot trefoil and Festuca ovina are also very common. Then numerous others begin to settle between them; small mosses and lichens, many flowering plants and grasses gradually close up the intervals, which changes to the short,springy turf which is probably responsible for golf.*

The bent-grass (Psamma) is widely distributed in the North Temperate hemisphere. In New Zealand (South Island) Mr. Cockayne finds quite a different grass (Desmoschœnus spiralis), which nevertheless is a sand-dune specialist, and acts in almost the same way. Another grass, Spinifex, colonises the sand-dunes in Java. ${ }^{9}$

On certain small sand-dunes at San Vicente near Concepcion in Chile, the author found yet another grass (Poa bonariensis, Kunth), which also managed to grow up through the sand, and binds the dunes together with a network of rhizomes.

On the crests of these sandhills, Euphorbia chilensis, Astragalus sp., and other specially adapted plants assisted to bind down the sand. The flora was exceedingly pretty, for many little slender convolvuluslike flowers, some 2 inches long (Nierembergia repens), Sisyrhinchium, and two beautiful Alstrœmerias were dotted about the surface. As the settlement becomes closer, one finds Lagurus ovatus (hare's-tail grass), Godetias, Phacelias, and other common Chilian weeds. Then small woody shrublets, spiny bushes of

* On the grey dunes of the Baltic, Aira canescens, A. flexuosa, Helichrysum arenarium, Galium mollugo, Hieracium umbellatum, and Artemisia campestris are said to be characteristic. 


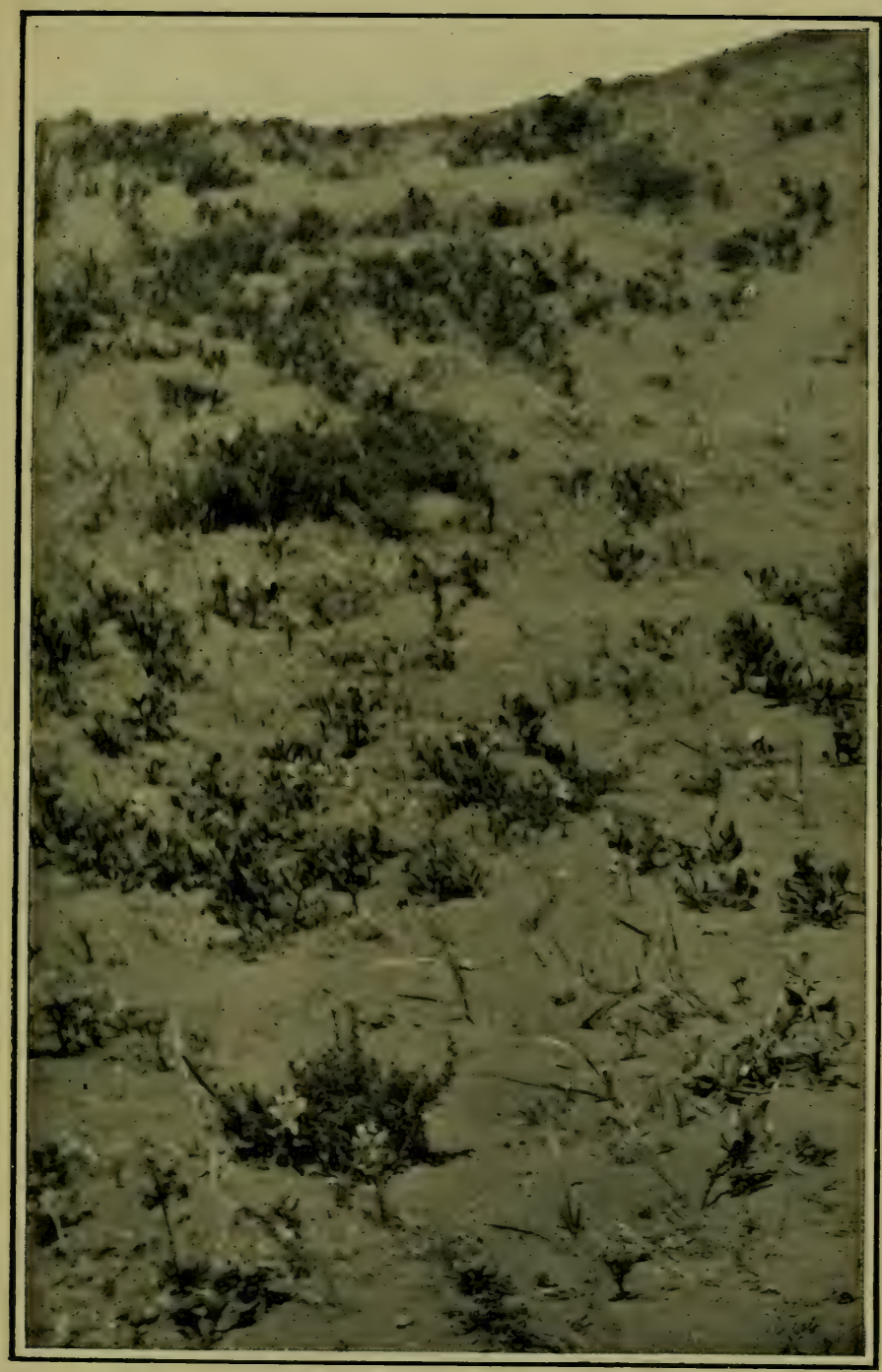

Author's Pliotograph

Sand-dunes at San Vicente, Chile

Many fine bulbs and interesting native plants assist in tying down the sand. 



\section{Seasides and Strand Plants}

Colletia overgrown with dodder, and the usual wild Chilian bush, which occurs wherever the forest is trying to grow up again.

In the Landes of France, Psamma had not succeeded in preventing the drifting in of seasand, which formed great chains of dunes, some of them 250 feet in height, interrupted by malarious marshes and lagoons. The whole country was desolate and almost uninhabited. Now it is a pine forest covering $1,500,000$ acres, full of villages and perfectly healthy. The change is due to the intelligent way in which French botanists have been able to assist Psamma in its usual undertaking.

About a hundred yards from the shore, a paling is first put up. It is of planks, but with intervals between them and about 3 feet above the ground. The sand blows through the spaces and forms a ridge behind the paling. Its accumulation is assisted by a rough wattled fence. As the sand accumulates the paling is raised and the fence renewed until there is a ridge of sand some 60 feet high. This is now planted along the crest with Psamma, which is looked after from time to time until the dune takes such a slope as is found to be permanent and stable.

Then behind this great barrier the seeds of Pinus maritima, whin and broom are sown down. It is in this way that the huge forest has been created which has now turned a desert into a healthy and valuable district. ${ }^{10}$

In the Dismal Swamp of the United States a very similar colonisation seems to be carried through without any help from man. Psamma is again the important plant, and is aided by other grasses and Myrica (sweet gale).

Then Pinus taeda replaces them on well-settled dunes and is eventually replaced by the ordinary deciduous forest. ${ }^{11}$ 


\section{Seasides and Strand Plants}

Spain has also very interesting sand-strand shrubberies of juniper, Artemisia, and the like.

The sand-dunes are exceedingly beautiful, for there are hundreds of the elegant broomlike Retama with shining silver-grey branches. These are covered in the right season with its flowers, which have rich purple sepals and snow-white petals. On the naked sand are gaily coloured Trichonemas, white Alliums, golden yellow Lotus, purple Malcolmias, \&c., all growing by the thousand.

Armeria also has found itself well suited in the Spanish climate, for it has varied into a whole series of different species. ${ }^{12}$

So that seashores and sand-dunes are full of interest and of beauty.

It would be exceedingly gratifying if it had been possible to say here how thoroughly our sand-dunes in Britain have been utilised by an intelligent appreciation and assistance of Psamma on the part of our own botanical specialists !

But that is not possible.

\footnotetext{
1 Kirchner, Loew, and Schroter. ${ }^{2}$ Guppy.

3 Hill.

Terras, Lesage.

5 Schimper.

6 Chrysler, Boodle.

7 Kew Bulletin, I908.

8 Reinke.

${ }^{9}$ Cockayne. ${ }^{10}$ Henry.

11 U.S.A. Agric. National Herbarium, vol, v. p. 6, I901.

12 Willkomm.
} 


\section{CHAPTER XV}

DESERTS

IN consequence of the world's rotation, there are certain latitudes in which the winds blow in a more or less definite direction almost the whole year through. When the trend of the coast-line is such that these winds are offshore or parallel to the coast, no rain reaches the land.

This explains, e.g., the nitrate deserts of Chile, the Namaqualand and Kalahari deserts in Africa, a small patch of very dry country in South Madagascar, and the West Australian desert.

These, however, are but small as compared with those of the Northern hemisphere, and especially the great Saharan-Central Asian desert which extends from the Atlantic to the borders of British India.

That this world is aged and drying up is by no means a new theory. It was a favourite subject for discussion with such ingenious scientists as Dr. Maillet and Celsius.

Prince Krapotkin and others consider that, in our own geological period, the world is rapidly drying up, and that Asia in particular is becoming far more desert than it used to be. ${ }^{1}$ It is of course indisputable that, for instance, the arid and desolate plains of Jungaria were once full of inhabitants. Dr. Sven Hedin discovered ruins of cities once wealthy and luxurious, with rich monasteries and evidence of once carefully irrigated fields in Teklamakan, which is now a desert of sand, so destitute of water and of forage that that intrepid explorer had the greatest difficulty in traversing it.

Still this does not necessarily prove that there is no 


\section{Deserts}

water, though it may be at great depths below the surface. The only real guide to the existence or absence of water is the character of the plant-world. The study of plant associations will assuredly lead to a definite knowledge of the capacities of an unknown and desert country when, that is to say, a sufficiently definite and practical classification of those associations has been attained.

The desert of Egypt, which, thanks to our own energy and enterprise, is now being made valuable agricultural land, seems to have been once a land of marshes and lagoons, where primitive Egyptians lived, like the hunting and fishing tribes of the Sudd region. The silt of the Nile has filled up those lagoons to such a level that it is only by irrigation that they can be forced to bear a harvest.

In other places, also, it is quite clear that it is man himself and his attendant animals (vegetable fiends like the goat, the camel, and the ass) that have destroyed the natural vegetation and turned what were once forestclad hillsides and well-watered slopes into glaring stony hills and arid sandy plains.

One cannot conclude, therefore, that the world is drying up from such facts as the deposition of silt which has made dry alluvium of what was once a lagoon country, nor from the desiccation due to the destruction of forests, and the havoc of the goat, camel, and ass.

But every sort of desert is always being invaded by vegetation.

A country so dry as to be absolutely destitute of plants is exceedingly unusual. In most deserts, scanty, scattered little plants of the most miserable character manage, somehow, to exist in spite of fierce sunshine by day and severe cold at night, not to speak of the friction of the gritty dust carried by gales blowing with- 


\section{Deserts}

out check over half a continent or so, and with only an annual inch or two of rain to depend upon, or perhaps with water buried 20 to 30 feet below the soil.

These "brave, poor things" are not, as a rule, beautiful. Some are exceedingly small, woody shrublets, densely branched, with every twig or leaf ending in a sharp thorn or spine. Others are covered with close cotton-wool or grey hairs. Cactus and the succulent euphorbias, and other fleshy plants are also characteristic of desert conditions.

The leafless, woody branches of the broom-like Retama, the hard wiry tussocks of Halfagrass, spinifexes, and especially thorny acacias belong to the desert-fringe, but their roots, probably in all cases, manage to reach moist soil or water, which lies 20 feet or more below the surface.

There is also an interesting group which grow in the desert, but only when it is, for a few days, not a desert.

After a shower of rain a multitude of tiny plants, with brilliant flowers, suddenly cover the surface. Three or four days of splendid sunshine sees these ephemerals spring up, blossom, set their seed, and wither away into impalpable dust. The seed remains patiently awaiting until, after a year perhaps, another shower calls into being a new generation.

In the Karoo, which is not quite so unmitigated a desert as the Kalahari or Sahara, the change produced by rain is enchanting.

The faintest tinge of green or grey spreads over the arid, brownish yellow of its surface. Soon it is studded all over with yellows, rich reds, whites, and other brilliant colours of Pelargoniums, Mesembryanthemums, Polygalas, and hundreds of other flowers.

One is apt to think that the very stones have become alive. 


\section{Deserts}

Things which look like fragments of white quartz or brownish-grey objects, flushed with dull green, which are exactly like thousands of stones around them, suddenly produce flowers. The first are found to be Anacampseros papyracea, and the second Mesembryanthemum Bolusii. ${ }^{2}$

Amongst the yellow and brown shales of Bruintje's Hoogte, or other similarly named places, one finds Mesembryanthema and Stapelias.

A casual observer or a hungry antelope would never have detected the difference between these objects, which are edible, in an emergency, and their surrounding stones.

After rain everything is fresh, vigorous, green, and growing. Dry, woody little mats, thorntufts a few inches high, flower and put out fresh leaves, and one finds Polygalas, Indigoferas, Aptosimums, and all sorts of odd South African genera in bewildering variety. The author noticed a patch of bright scarlet a mile and a half away, and found it to be a single plant of Brunsvigia.

In a week or two all is over. Everything green has withered up, and its brownish, yellow or grey dust fades into the monotonous aridity of the Karoo, which remains a desert for months together.

It is the succulents which are, perhaps, the most impressive of all desert plants. Their odd shapes, spheres, fleshy pillars, candelabras, swollen, gouty-looking stems or bulbous dropsical leaves are very remarkable. Many have long grey hairs, or are covered over by a system of stout curved spines, which are generally sharp, smooth, and shining. They have in most cases a peculiar pale bluish or light green colour, which is due to a deposit of wax on the outer surface.

But their most remarkable peculiarity consists in some 


\section{Deserts}

strange modification of the protoplasm which enables them to resist heat, and also to breathe internally without opening their pores, which might allow the dangerously dry air to enter their bodies.

In the American clesert a thermometer placed in the body of a cactus (Cereus sp.) showed a temperature of $45^{\circ}$ to $46^{\circ} \mathrm{C}$. Indeed their body temperature is often above that of the earth near them. Askenasy found that when the sand showed only $43^{\circ}$ to $44^{\circ} \mathrm{C}$., the leaf of a Sempervivum had a temperature of over $5 \mathrm{I}^{\circ} \mathrm{C}$. In one day they are subject to extraordinary fluctuations. At 7 to 8 A.M. the leaf of Sempervivum tectorum showed $\mathrm{I} 3^{\circ} \mathrm{C}$., and at 2 to 3 P.M. it was at $49.6^{\circ} \mathrm{C}$., which means a difference of over $33^{\circ}$ in a single day.

Their exact system of keeping alive in deserts is not understood. In dry weather Cereus and some other cacti seem to shrink together so as to show deep longitudinal grooves. This shrinking will close up their stomata or breathing spores. ${ }^{3}$

In wet or misty weather they expand so that the grooves become shallower, like those of a camera-case when drawn out. Then the moist air penetrates into a curious system of air channels, which branch in and out amongst the green assimilating cells. At such times they are actively growing and even forming (Echinocactus sp.) green leaves, which drop off as soon as the drought begins. ${ }^{4}$

They have the curious property of being able to give out carbonic acid without taking in oxygen. One does not like to charge them with alcoholism, but it seems that they must somehow produce oxygen for respiration without allowing the dry outside air to enter the body. So it is quite possible that some kind of alcoholic fermentation is really going on within these innocentlooking fleshy stems. 


\section{Deserts}

In other respects they are also very interesting. Such a solid pillar as the Cereus or giant cactus of America has to withstand considerable wind pressure. It has an interesting lattice-like arrangement of woody fibres which is ingeniously adapted to give support against the wind, and yet to allow of the contraction and expansion which we have already mentioned.

The use of these spines or thorns is obvious enough. Antelopes or guanacoes, or even rats and mice, would surely break into them when perishing of thirst. Mr. Darbishire, ${ }^{5}$ however, considers that the glancing thorns are intended to reflect off the sunshine, and that this is also the explanation for the hairs of many Mesembryanths.

The Euphorbias of the Canary Islands and many desert fringes are quite efficiently protected by their acrid and poisonous milky juice. A drop on the skin may produce a blister, or even total blindness if it reaches the eyes.

The grey hairs or cotton-wool which shrouds and swathes many desert plants is another interesting character ; it is also found in, for instance, the common cudweeds (Gnaphalium and Filago). Such hairs will greatly hinder the loss of water by transpiration; they also diminish by about one-half the amount of light that falls upon the leaf-surface. ${ }^{6}$

The flannel-like or dense tangled mass of hairs which coats the Edelweiss, South African Helichrysums, and the Zillas of the Egyptian desert are therefore distinctly serviceable.

Very young leaves belonging to all sorts of plants are often covered with hairs whilst still enclosed in the bud, but when they unfold and expand they often lose all trace of them. In these desert plants the primitive hairs seem to have remained and indeed increased. 


\section{Deserts}

The remarkable woodiness and thorniness of desert plants is probably directly connected with the dry conditions under which they live. The absence of leaves may have also been brought about in the same way.?

Even our common whin forms leaves when it is quite young or kept particularly fresh and moist, but there is generally no trace of them when it grows in a dry and exposed place.

The connection between thorns, spines, and browsing animals is a very old story, but unfortunately the controversy has become a little acuminate and requires to be very gingerly treated.

One cannot possibly believe that a plant said to itself, "Those — goats are destroying my leaves, and I shall (or will) make thorns and spines to daunt them."

But as a matter of fact, not of theory, in every country open bushlands, clearings in temperate forests, desert fringes, and deserts are generally remarkable for the number of thorny and spiny plants. But it is just such places that a hunter of big game will first visit, for they are always full of antelope and other animals.

This coincidence is not confined to desert or dry countries. Patches of brambles and rasps, thorn thickets, furze, and whin are generally favourite places for rabbits, and even pheasants and partridges, in our own islands.

Thick, close forest or woodlands is as a rule very poor in game, simply because there is but little grass, and if it is natural forest it is by no means easy for them to traverse it.

Mr. Leavitt," in an interesting study of the cockspur thorn, points out that "the first step is the hardening of a small bit at the end of the winter bud." In open, exposed, and especially in dry or desert countries, the drying up by exposure of the extreme tip of a branch or leaf must be an exceedingly common occurrence. 


\section{Deserts}

Anything that causes a loss of water must surely tend to make the tissues more woody and less soft. One of the most interesting spiny plants is the gum-tragacanth (Astragalus). This has compound (pinnate) leaves, which are at first quite green and not perceptibly different from ordinary leaves. But as the leaf grows older it dries up and the leaflets fall off, so that in the end the leaf-stalk and midrib becomes a sharp, hard spine, which is an efficient protection to the next season's green and juicy foliage.

The history of a hedge-thorn is quite similar. In its extreme youth it is quite soft and flaccid except for the extreme tip, which may have been killed by frost or exposure to sunlight. If the hedge is pruned or much cut about, there will be a great loss of water from the scars and cuts made by the bill-hook, and in such a case an unusual number of the branches become sharp, hard, and business-like thorns (see also p. 25).

It has also been shown by direct experiment that thorny plants cease to form these weapons when cultivated in a moist and humid atmosphere. This has been done by several observers, and lately by Mr. Cockayne ${ }^{8}$ for Discaria Toumatou. He found that in strong sunlight this plant has no leaves, and is very much branched and thorny. But in moderate light, and when grown with sufficient moisture, it develops leaves and loses almost all its thorns.

As to the common holly, it is the case that its lower leaves are often spiny when the upper leaves are perfectly smooth and harmless. We cannot suppose that it has the intelligence to know that only its lower leaves will be attacked by animals. Has it, like pruned hedges, got into the habit of arming its lower leaves in response to continual loss of water by evaporation at that level ?*

Thorns and spines are generally very well placed and

* "The Romance of Plant Life." 


\section{Deserts}

so contrived as to be thoroughly efficient. In the Egyptian desert, near the Pyramids and about the level of the highest inundation of the Nile, a small thistle is fairly common. It (Carduus acaulis) consists of a small rosette of leaves which lies flat on the ground, and a head of flowers with no stalk but seated in the centre. Each bract of its involucre is continued into a long yellow very sharp spine. They are so arranged that the sensitive nostrils or tongue of a browsing animal must somehow dispose of them before the green leaves can be touched.

The wait-a-bit thorn (Acacia detinens) has also a very ingenious yet simple arrangement in its stipule thorns. They are in pairs; one is straight and pierces the nose of an animal, and the other is crooked and would catch in its tongue.

This genus, Acacia, has a very interesting part to play in the economy of most dry countries. It is the rule to find all deserts surrounded by a broad or narrow belt of thorny thickets or open thorn-woods in which Acacias or allied forms are particularly common. ${ }^{9}$ This fringe of Acacias seems to be present along the whole southern edge of the Sahara, from the Atlantic Coast to Egypt, and forms a belt 375 miles wide between Tuat and Gao on the Niger. ${ }^{10}$ It is found in Northern Africa wherever the incessant demands for firewood have allowed it to persist. In South Africa, in Chile, and in Australia a similar belt seems to be present. For such a position it has many advantages. The long roots easily penetrate to depths of 20 or possibly 30 feet in search of water.

Some Australian species have vertical flattened leafstalks which are placed edgewise to the sunlight, and in consequence are not likely to be injured by excessive heat.

Many of them on being wounded produce gums such as gum-arabic and senegal, which, flowing out profusely 


\section{Deserts}

from the injured surface, at once covers over and gums up the scar, so that but little water can be lost through a wound.

Against the browsing animals, which swarm in such country, they are especially well protected by thorns of a formidable character, or in some Australian cases by their bark, which contains some 26 to 48 per cent. of astringent tannin.

When one visits the acacia scrub in those rare places where it is still in its natural condition, scarcely traversed except by some wandering slave-raider or roving Bedouin, it is the abundance of game that impresses every traveller.

Herds of zebra, ostriches, the gaunt and indescribable babiroussa, large-eared and long-necked gazelles, and other antelopes may or used to be seen continually. This was the case, e.g., in the Taru desert of East Africa. Hunting is difficult, for the long necks of many of the animals are quite invisible against the dull yellowishbrown background, so that they can see long before they can be seen by the sportsman. In such places it is more than probable that in the struggle between plant and grazing beast it is the first that is gaining.

Those animals, not improbably, assist rather than injure the vegetation. Their manure is scattered over the dry soil, which is for the most part entirely of mineral origin, and makes it a better and richer loam (see p. I98).

Such acacia scrub is extraordinarily variable. In some places it is almost a forest with closely set trees; elsewhere the trees are scattered, and the ground between them is dotted with scanty tufts of wiry grass or sedges. Especially near the desert proper one may find an "orchard steppe," so called from the scattered little trees, about 20 to 30 feet high, which are not unlike apple or pear trees. 


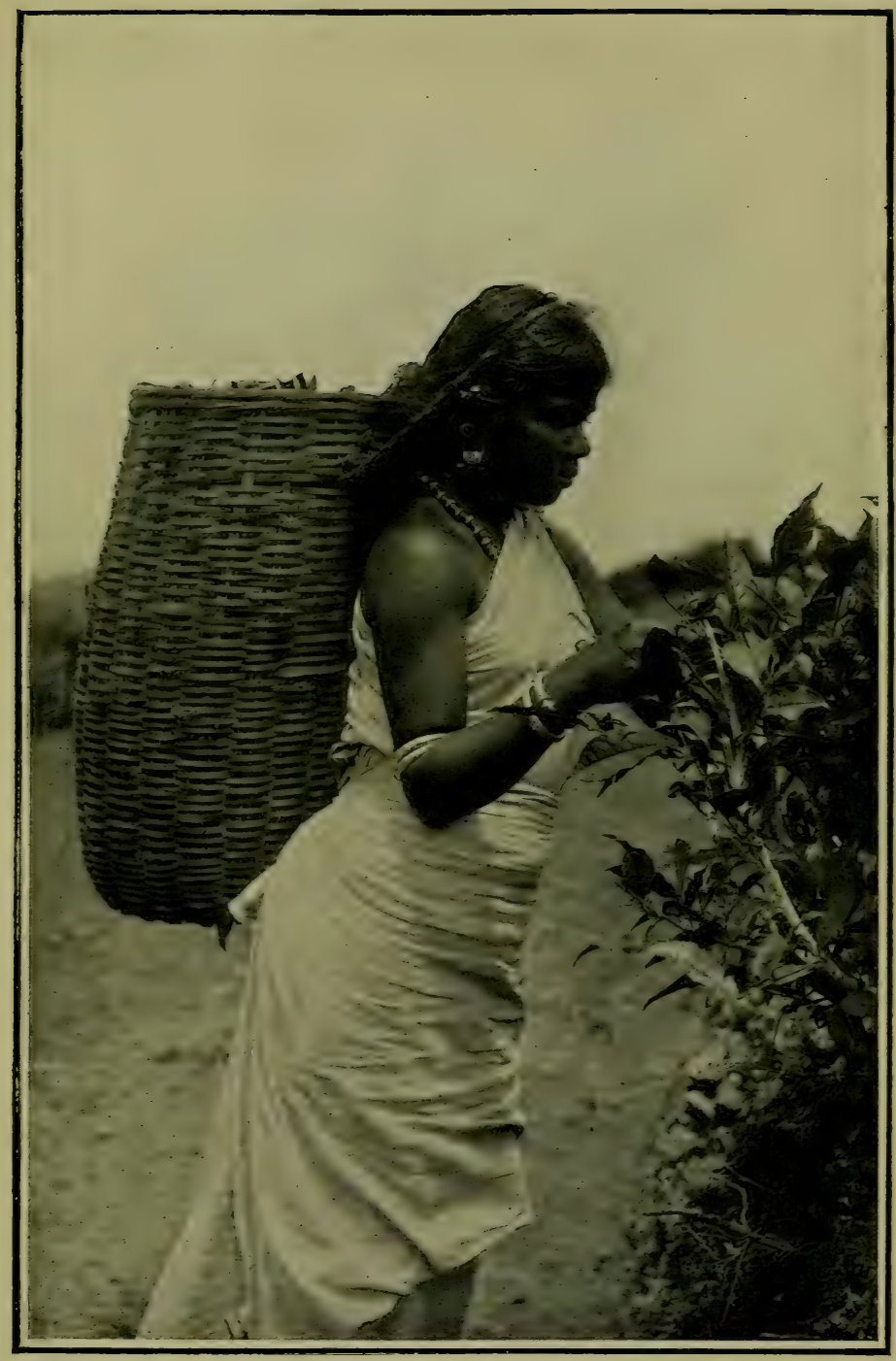

Photographed by]

[Skeer \& Co., Cieylor

Plucking the Leaves from a Tea Plant

A plucker with her basket nipping off the tip of the shoot, or two leaves and a bud. 



\section{Deserts}

But near the real desert, the last shrubs are almost always small scattered acacias which are either the skirmishers or a vanishing rearguard of vegetation.

In places where man is concerned, vegetation has no chance whatever. The battle is unfair, for his big battalions of goats, sheep, donkeys, camels, and the like are provided with water and are not disturbed by lions and leopards.

But at least sometimes, under natural conditions, it does not seem at all unlikely that the desert would be encroached upon, and finally occupied by vegetation, which is, as we have tried to show elsewhere, assisted even by its apparent enemies (see p. I98).

We must mention here, however, one plant, Welwitschia mirabilis, for it is surely perhaps the strangest and most antiquated of all plants now living on the earth's surface.

It grows on the stony plateaux of South-West Africa, in one of the worst deserts of the world, but so far as is known only in two places (near Mossamedes and at Haikamchib). Here there are three rainy days in an average year, and the mean annual rainfall is one-third of an inch. But sea-fogs occur almost every night, and with extraordinary punctuality- "about midnight ... a gloomy bitter cold mist, which soon enveloped us in total darkness and completely saturated every article of our dress." 11 A few hours after sunrise there is not a sign of this moisture. Welwitschia has its plateau almost entirely to itself (except for a strange Cucurbit, Acanthosicyos horrida, which has long thorny half-buried stems).

The Welwitschia consists of a brownish yellow crown, placed flat on the ground, of "shapeless masses of curled and twisted leaf ribands standing out in bold relief from the sharp, glistening dead landscape." It has also long 


\section{Deserts}

roots which probably obtain water from a great depth. Where it does grow it is abundant enough, and little clumps of four or five are found growing or naturally grafted together. The flowers are rather like those of the monkeypuzzle cones at first sight, though much smaller. But the botanical details show that they are entirely unique, and quite different from those of any other known plant. The male flowers are also in curious little conelike inflorescences arranged round the crown or cup. ${ }^{12}$ They are sticky and attract certain small insects, which probably carry the pollen to the female flowers. There it lives growing to a ripe old age of well over a century, and it no doubt expected to be left alone for ever. But, alas, that is not the case, for Hottentots burn its leaves and "a red and yellow leaf-bug " (Odontopus sexpunctulatus, Cast.) bores the cones through and through!

So even here, in the most deserted and useless part of the most backward of all the Continents, we find man, the Hottentot, in the far too frequent rôle of a destroying angel, exterminating this unique, aged, and venerable plant, which expected no doubt in time to occupy and replenish German South-West Africa. It does its best to improve the soil, for moist patches of sand are found under masses of leaf débris, and these form a shelter and abiding-place for multitudes of insects.

\footnotetext{
${ }^{1}$ Suess, Guppy. $\quad 2$ Marloth. ${ }^{3}$ Spalding.

4 Cannon. ${ }^{5}$ Darbishire.

${ }^{7}$ Leavitt. ${ }^{8}$ Cockayne, Lothelier, Mittmann.

10 Gautier. $\quad{ }^{11}$ Andersson.

${ }^{6}$ Ursprung.

9 Scott Elliot.

12 Pearson.
} 


\section{CHAPTER XVI}

\section{SUNSHINE, RAIN, AND WIND}

IT is a fact that all flowering plants have somehow suited themselves to some particular place in the world, but it is very difficult to understand how they managed to do this. The situations in which certain particular species have established themselves are very strange. One special alga lives only in the hollow hairs on the toes of a rare South American sloth.

The common darnel is generally affected by an interesting fungus which develops in the seed. About 85 to 98 per cent. of the plants are so affected. When the seed is sown and germinates, the fungus grows as the seedling develops and again appears in the seed. It does not injure the grass, which is even said to be more vigorous when it contains the fungus. ${ }^{1}$

Dr. Borchardt found the seeds of this weed in certain graves at Abusir in Egypt, belonging to the time of King Newozee, that is, to 2400 B.C. So that this fungus has continued to affect Lolium temulentum for at least 4300 years.

In one particular cavern which is dark and moist (the Hermannshöhle at Rübeland), a special variety of Bryum capillare is to be found which, so far as is known, does not exist anywhere else. ${ }^{2}$ There are lichens which have trained themselves to living only on plaster or on the resin of some particular kind of pine-tree. One species has never been found except on burnt earth. ${ }^{3}$

Amongst flowering plants there are such forms as Wulfenia carinthiaca, which is only known from one particular rocky ledge (Gärtnerskugel) in Carinthia. 


\section{Sunshine, Rain, and Wind}

On Cologne Cathedral one can see rosebushes and privets which have been there established by birds. ${ }^{4}$ On many stone bridges one may find tiny plants of the black maidenhair, which are not to be discovered anywhere else within several miles. Other cases are the well-known alga of the snow, and the curious gossamerlike snow-mould, which seems to be only found on decaying vegetable matter in the hollow formed by a thaw between the snow and the earth. ${ }^{5}$

There are certain plants in the Amazons which only occur in the "gardens" formed by intelligent ants and so on. Such examples show how ingenious plants may be in adapting themselves to the strangest existences.

In order to live under such special and peculiar conditions, great changes are required not only in the outward form of leaves, stems, and roots, but also in microscopic structure. The peculiarities of desert plants and water plants belong rather to the botany of ten years ago, and have been thoroughly studied by Henslow and many others. ${ }^{6}$

There are two different methods which have been used by various botanists of late years in the study of environment. One may take one particular genus, say the oak tree, and study the leaves of every species of Quercus in the world in connection with the various climates in which those species are found.? Or one may take some particular kind of habitat or climate and distinguish the type or types of leaf that seems to predominate under those special conditions.

The great work of Dr. Hansgirg on the shapes of leaves is an instance of this last method. As no one has ever studied leaves with the same thoroughness and wide experience, he has certainly earned the right to generalise, and his conclusions are therefore of great importance. According to him, the object of every 


\section{Sunshine, Rain, and Wind}

leaf is to combine the greatest possible capacity for work with the smallest expenditure of material and energy. And also the shape of every leaf and its internal anatomy in every sort of plant, are in harmony with the external conditions to which it is exposed, such as degree of moisture, chemical and physical nature of the soil and climate generally. ${ }^{8}$

It is this harmony between the live plant and the outside world that is always a fascinating object of research. It can be studied in all sorts of ways.

Sometimes the results have been most remarkable. There is, for instance, a little group of plants, the Podostemaceæ, which grow generally on rocks in the spray of waterfalls. They are all very curious, and some of them are so exactly like mosses or algæ, which might occur in such places that no one except a botanist would ever distinguish them to be flowering plants. This is the case, for instance, with the little Ligea Glaziovii described by Warming. ${ }^{\text {? }}$

At present most work is being done by statistical methods. Thousands of leaves, or of some other measurable unit, are examined and catalogued. Then those of the various localities are contrasted, and if possible the result of some special character, say sunshine or shade, is deduced from the whole series of measurements. Unfortunately such calculations have often been carried out for many thousands of flowers and leaves without considering the environment at all! In such cases, one can see that the results simply illustrate not the variation in the flower or leaf, but rather the different conditions or environments under which they have been grown!

There is always a slight variation even amongst plants growing in one particular locality, even although they inherit, not only the characters of their parents, but also 


\section{Sunshine, Rain, and Wind}

the identical climate which their ancestors have endured for many generations. ${ }^{10}$ But the environment may change altogether even in the same place. When, for instance, an open rough hillside is planted with young spruces, the conditions are entirely altered as soon as the trees become tall and bushy enough to overshade the ground. At first there may have been an abundance of grasses, quantities of red campions, foxgloves, blue bugles, brambles, and raspberry bushes, and in the more open places the dog violet (Viola canina).

As soon as the young trees begin to close in over the soil, many of these plants vanish. The brambles and roses will try to become climbers, straggling over the branches. The campions and other herbaceous plants will not flower but produce runners or tubers of some kind. Dr. Krasan declares that under these conditions Viola canina becomes Viola Riviniana, but it is dangerous to agree with him, for most British botanists would emphatically protest.

Such a thoroughgoing change as this affects every plant in the wood and even the young spruces themselves. Many plants of the ground flora vanish or retreat into underground reserve stores. Of those that remain, none can be unaffected either in external form or in internal structure. ${ }^{11}$

Even in one and the same valley there may be limestone outcrops or other special and peculiar soils. In that case one may discover closely allied species inhabiting the same valley, but keeping strictly to their own territory. Soldanella minima, for instance, occurs on chalk in central Europe, and S. pusilla replaces it on other rocks. Such replacing species are supposed to be parallel forms derived from some common type. (The usual German term for such species is vicariirender, which might be best translated as curate species, for the I 84 


\section{Sunshine, Rain, and Wind}

vicar will represent the dominant or master species found in all the best places.) But many cases are known in which one can change one sub-species into another, simply by transferring it to the other's territory.

Dr. Krasan found that Potentilla arenaria became P. viridis when planted on the sunny slopes where that species lived. The reverse experiment with $\mathrm{P}$. viridis led to distinct changes in the direction of $\mathrm{P}$. arenaria, but not to a complete transformation. ${ }^{12}$

In Servia also three at least of the high alpine plants became common lowlanders when sown in the lowlands.* 13 Soldanella alpina replaces S. montana in the higher alpine region, and many other cases might be quoted. ${ }^{14}$

The differences brought about by strong wind and a dry or sunny atmosphere are very marked indeed. Under such conditions the transpiration of water becomes extreme, and the skin or epidermis cells are especially affected. Their outer walls are reinforced by the deposit of more and more cellulose (probably due to the sacrifice of more protoplasmic elements for this purpose). This change is very well shown by our common bracken, which varies greatly according to the place in which it grows. In shade the leaves are thin and delicate, but in a dry exposed place they become thick and develop a special layer of thick walled cells (hypoderm). Indeed, by altering the outside conditions, one can leave half a leaf to become of the dry or sun type, and change the other half into the shade form by arranging some sort of shelter for it. ${ }^{16}$

There is a very interesting account of the "patanas " or upland district of Ceylon by Messrs. Parkin and Pearson. ${ }^{17}$

* Trifolium orbelicum, Aster alpinus, and Alyssum repens became T. repens, A. amellus, and A. montanum. See also the interesting division of the Geraniums according to climate and geography by Knuth. ${ }^{10}$ 


\section{Sunshine, Rain, and Wind}

This district consists of two quite different regions. There is a dry, sunny, or wind-swept portion, and also a sheltered or "wet" patana which is in the Hakgala valley. These authors chose forty plants from the dry and forty-two from the wet patanas, and after careful microscopical measurements averaged the thicknesses of the epidermis cell walls in these eighty-two cases. They found that the average for the "dry" plants was 6 micromillimetres ( 250600 ths inch), and for the "wet" 5 micromillimetres ( $\frac{1}{500} 0^{\text {th }}$ inch). This is a good illustration, for the "wet" patanas have not really a wet climate, as they are swept by westerly winds during the south-west monsoon.*

The little sandwort, Sagina procumbens, has also been examined in the same way. It was found that when it grew on dry sand it had from three to four layers of corky cells, but on moorlands only from two to three layers. ${ }^{18}$

There are many other observations which might be quoted here. Even in a garden one can find extraordinary differences in the commonest weeds.

A groundsel growing on a dry cinder path will have a flat, often reddened iosette of short leaves, and one small head of flowers nearly seated, or very shortly stalked, in the middle of them.

In dark places near some rank herbaceous plant, one will find a tall, slender, drawn-out groundsel with two or three nodding heads and long, distant leaves of quite a different shape. It may even make a half-hearted attempt to curve or twine round some strong branch. Such a groundsel at once reminds one of the twiners common in shady woods, whilst its ally on the cinder path is like a very common type of the deserts and Tibet.

Sunshine alone has extraordinary power to change

* As regards other characters the authors have no very conclusive results. 


\section{Sunshine, Rain, and Wind}

the character of flowering plants, and even to give some species a distinct advantage over others.

Along railway lines in Southern Sweden the flowers on the north side of the line (with a southern exposure) will be chiefly Barbarea vulgaris, Convolvulus arvensis, Anthemis tinctoria, and Alyssum calycinum, and there is no close carpet of mosses but only small tufts of Ceratodon, Tortula ruralis, and Funaria. But on the south side (with a northern exposure) there is a close moss carpet (Hylocomium), and the common plants are buttercups (R. acris), grasses such as Aira cæspitosa and Cerefolium silvestre. ${ }^{19}$

There is a peculiar reddish colour which the reader must have noticed on plants growing in very exposed places, and which is due to a special substance called anthocyan. This colour seems to be directly produced by the effect of certain kinds of sunlight (the violet and ultra violet rays). But when once formed it protects certain valuable ferments or enzymes, such as diastase (which changes starch into sugar), from being destroyed by those same violet rays. So that in anthocyan the evil itself seems to have produced exactly what is required in the way of a remedy. ${ }^{20}$

Sunshine also helps to produce such substances as carotin, which are found in flowers, ${ }^{21}$ and as we have seen intensifies not only flower colours but also perfumes. Nor is it only colour that is affected but also the number of stamens. In warm places it has been found that the chickweed has more stamens than elsewhere. On such a plant as the common Bocconia the number both of stamens and carpels is always greater in those flowers that are well placed as regards light and which are well supplied with nourishment. ${ }^{22}$ This effect of nourishment and more genial conditions generally is also very well seen in poppies (P. Rhœas) and marsh marigolds. As 


\section{Sunshine, Rain, and Wind}

the season becomes cold and wet, these flowers become smaller and have fewer stamens and carpels.

An enormous amount of labour has been spent in counting (like Marguerite) the number of ray florets of asters, sunflowers, chrysanthemums, and other Compositæ. Such flowers are, of course, really heads of florets, and might be compared to contracted or foreshortened inflorescences. These outside ray florets must, one would think, be in some way connected with the arrangement of the leaves on an ordinary stem (see p. I2I).

We would expect then to find the same numbers as occur in leaf arrangement reappearing in these ray florets, and that is found to be the case.

The commonest or most fashionable number of ray florets (that is, the mode) is generally one or other of the series $5,8, \mathrm{I} 3,2 \mathrm{I}, 34,55, \& \mathrm{c} .^{23}$

In the annual sunflower the mode is 34 or 55 , but if such plants are badly treated they will have as a rule only 2 I or even only $\mathrm{I} 3$ rays. If well supplied with artificial food or manure they may have 89 rays. Oxeye daisies and asters, which come out late in the season, have also but few rays. These few cases show how greatly the climate and especially sunshine may affect the vigour of the plant and quite alter the size and number of flowers.*

Rainfall has also a marked effect and especially on the leaves. In a rainy climate, for instance, smooth glossy leaves like those of rhododendrons and laurels are distinctly useful. The rain dries off them at once. If they remained wet, the conditions for the germination of fungus or algal spores would be much more favourable. Another interesting point in rain-leaves is the

* The number of leaves may be also increased as well as their size, after Goebel and Groom. ${ }^{24}$ 


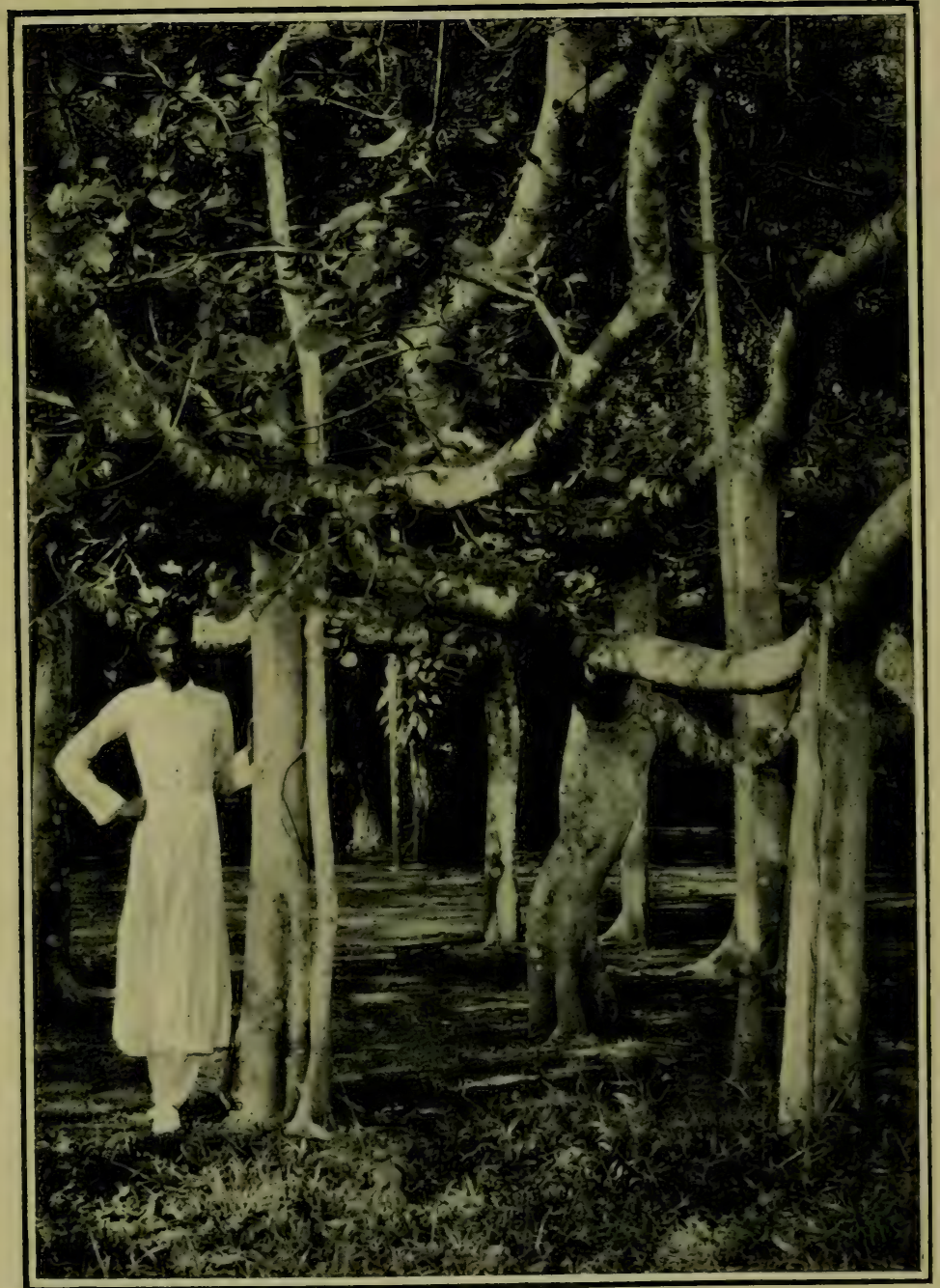

Stereo Copyright, Underwood \& $U$.

[Lordon ard New York

\section{A Banyan Tree}

One single banyan tree, tooo feet in circumference, Calcutta. The stems are really roots descending from the branches. 



\section{Sunshine, Rain, and Wind}

long fine point which many of them possess. This acts as a spout or gutter, draining off the water from the rest of the surface.

But to really appreciate the trials of leaves and the extraordinary beauty of their mechanism, one has to watch a tree in full leaf exposed to a strong westerly gale. Everything is in movement, bending and swaying backwards and forwards; great strain is thrown on the roots, which will be at one moment buttresses and the next acting as taut cables resisting the pull of the return swing. Every detail in leaf-shape and arrangement, in habit of branching, and in the character of the tissues is obviously so contrived as to resist the enormous stresses and strains that are at work.

No two trees have quite the same ideals. In the ash the leaf-stalk yields, and each leaflet folds at its base and becomes acute-angled. In the birch everything swings so that every leaf becomes edgewise to the storm. The beech is far more rigid and stiff, yet the leaf-edges twist into the right position.

Some careful experiments have brought out both the ingenious contrivances of these leaves and also their extraordinary strength. These were carried out with artificial storms produced by electric ventilators, and are unfortunately too detailed to give in full. ${ }^{25}$

In the black poplar, e.g., the leaf-folds and different leaves cling together, in such a way that a leaf surface of over Io square centimetres ( 1.55 square inch) has, when exposed to a gale of 10 metres ( $32.8 \mathrm{feet}$ ) per second, only 1.2 square centimetre (.r 86 square inch) of area.

A sycamore leaf which had a surface of ${ }^{1} 64$ square centimetres ( 25.42 square inches) was found to be unable to bear a weight of 827 gr. ( $\mathrm{I} \frac{3}{4} \mathrm{lb}$.). But even in a hurricane of 60 feet per second, the force of the I 89 


\section{Sunshine, Rain, and Wind}

wind could scarcely amount to $490 \mathrm{gr}$. (about I lb.), so, when taking into account the reduction of the leaf surface, it seems unlikely that even the worst hurricanes could tear away its leaves.

In a general way, mechanical tissue is at once produced wherever strains or stresses occur. This is perhaps most easily seen by looking at the ribs and strings of ordinary herbaceous stalks and petioles. One can follow these strings quite easily by cutting across the stem, and it is then easy to see how exactly they are placed where the strength is required.

The strength of the wood in a tree and its branches varies very much, but is always best developed where the most strain is likely to occur. An exposed tree has tougher and denser wood than one grown in close forest. But if a forest tree is left by itself when its companions are felled, its wood will (if it survives) become tougher and more mechanically effective. ${ }^{26}$

In leaf, stem, and root, the right sort of mechanical tissue, whether for support as a buttress or to act against a strong pull or tug, is always found in the place where resistance or tenacity is wanted. Dr. Wildt carried out some pretty experiments in the way of stretching roots artificially by means of a weight attached to a thread, which was passed over a pulley and fastened to the root. $\mathrm{He}$ not only called into existence mechanical tissues in these roots but altered their anatomical structure. ${ }^{27}$

Soalso, growing fruit-stalks develop mechanical strings and cords as soon as the fruit becomes heavy and requires support. ${ }^{28}$ This mechanical or strengthening tissue depends for its efficiency both on the shape of the elements composing it and upon their constitution.

The tracheid, which is the ultimate unit in the formation of wood, is a marvel of engineering ingenuity, of 


\section{Sunshine, Rain, and Wind}

which one can only realise the perfection after verycareful microscopic dissection, and by much constructive imagination. But it is unfortunately impossible to describe either the difficult chemistry of wood and cellulose, or the mechanical beauty of the tracheid.

One other little point should be mentioned in this chapter, for it is but seldom noticed anywhere.

The stems of most herbs and shrubs are not either straight or cylindrical. There is usually a zigzag curvature and a system of indistinct grooves and ridges. Where the leaf joins the stem there is often a bold sweeping curve at the leaf base, continued as a faint elevation down the stem. Where leaves are opposite, a ridge joins the bases and is often artistically set off by a pallisade of hairs. Leaf veins are often sunk below the surface, and lead down to intricate little hollows, where the bud is nestling between leaf and stem.

These sculpturings and ornaments are regulated by three distinct and different governing principles. There is (I) the mechanical support of the stems, and also (2) the protection of the young bud in the hollow or axilla of the leaf (the "oxter," as it is called in Scotland, is exactly like the bud axil of many leaves). But there is also (3) another intention, which is to utilise rain and atmospheric dust. The importance of dust has not been realised until quite recently.

The researches of $\mathrm{Mr}$. Aitken in this country have shown that even on the summit of Ben Nevis it is very difficult to get a sample of air with only one dust particle per cubic centimetre (.06I cubic inch). When Pasteur, on 20 th Sept. I 860, attempted to get a sample of germfree air at the Montanvert near Chamonix, he had to raise his flask above his head to get rid of body currents and breath, then by careful manipulation break off the point of the flask, which was then hermetically sealed by 


\section{Sunshine, Rain, and Wind}

a special lamp. Even with all these precautions one of his twenty flasks was contaminated. ${ }^{29}$

Such dust is of the most varied character. It may be volcanic ash or desert sand, or carbon and soot from household fires, or the poisonous waste of chemical works, but a very large proportion of it is organic. Where there is a close vegetation of wood, or grass, or, for instance, in a garden, pollen, microbes, lichen-, fungus-, and algal-spores will be extremely abundant. But even in deserts or open and bare places, bacteria and these other minute spores are not necessarily absent, for if the dust of the Krakatoa eruption really went three times round the world, a bacterium might come to land anywhere.

Quantities of these dust particles are washed down upon the earth's surface in rain (indeed every raindrop or mist-globule condenses upon one particle at least). This is useful as a manure to the soil ; spores and germs are also distributed in this way. But a large amount of the rainfall and of its organic and other dust is intercepted by the leaves and stems. There are most interesting arrangements to utilise this atmospheric manure, of which some are described and figured in Kerner van Marilaun's "Natural History of Plants."

Until recently many botanists refused to believe that the rain-water could be directly absorbed by leaves and stems. Desert and rock plants are in some places obviously kept fresh and vigorous by sea-fog and mist ; it was also shown by direct experiment that plants can be revived by moistening the leaves even if the roots are dry, but still this prejudice survived.

The probable reason is not without interest. Professors of botany feared that their students might become confused and bewildered, and so were unwilling to admit that water with anything dissolved in it cannot help entering the leaves. 


\section{Sunshine, Rain, and Wind}

In the common red loosestrife (Lythrum Salicaria) the rain falling on the leaf is led down the groove of the stalk, and then by a bold sweeping curve of the leaf base downwards; it then runs down the grooved stem and passes over the next bud below, where it is strained through a row of small reddish hairs which intercept all dust.

In many of the dead nettle order (Mentha aquatica, Galeopsis tetrahit) there is a raised line which connects the opposite leaves and which seems at first to be a useless ornament. But the water from the leaf-stalks spills across above this line, and its dust is strained out by special rows of hairs.

Naturally one of the objects of this book is to tempt some readers at least to examine plants for themselves ; these rain gutters and grooves and straining hairs are easy to trace and interesting, for no two systems are alike. That there is useful material to be found amongst the dust is obvious from the small table which follows, and which shows what were actually found in the gutters :-

\begin{tabular}{|c|c|c|c|c|c|c|c|}
\hline & Pollen. & $\begin{array}{l}\text { Algæa, } \\
\text { Pleuro- } \\
\text { coccus. }\end{array}$ & $\begin{array}{l}\text { Bac- } \\
\text { teria. }\end{array}$ & $\begin{array}{l}\text { Fungus } \\
\text { Spores. }\end{array}$ & $\begin{array}{c}\text { Rust } \\
\text { Spores. }\end{array}$ & $\begin{array}{l}\text { Lichen } \\
\text { Soredia. }\end{array}$ & Mites. \\
\hline Lythrum Salicaria & $x$ & $x$ & $x$ & $x$ & $x$ & $x$ & - \\
\hline Mentha aquatica & - & $x$ & $x$ & $x$ & - & $x$ & - \\
\hline Agrostis alba . & $x$ & $x$ & - & - & - & - & - \\
\hline Phlox (garden) & - & $x$ & $x$ & $x$ & - & $x$ & - \\
\hline Lysimachia barystachya & - & $x$ & $x$ & $x$ & - & $x$ & - \\
\hline Michaelmas daisy & $x$ & - & $x$ & $x$ & - & $x$ & - \\
\hline Veronica longifolia & $x$ & $x$ & $x$ & $x$ & $x$ & $x$ & - \\
\hline Polygonum saghaliense & - & $x$ & $x$ & $\mathrm{x}$ & - & - & - \\
\hline Harpalium rigidum & - & $x$ & $x$ & $x$ & - & - & $x$ \\
\hline Eryngium dichotomum & - & $x$ & $x$ & $x$ & - & - & - \\
\hline Antirrhinum majus & - & $x$ & $x$ & $x$ & $x$ & - & $x$ \\
\hline Cucurbita pepo & - & $x$ & $x$ & - & - & - & - \\
\hline
\end{tabular}

Such things as pollen, algæ, and spores of all kinds are extremely rich in nitrates, phosphates, and other 


\section{Sunshine, Rain, and Wind}

food material, and would of course make excellent manure.

Bacteria are present to work up such decaying matter as these. Unfortunately these observations were made too late in the season to know whether mites were common or not. Should it be found that they frequent these plants and devour the fungus spores, pollen, \&c., then their droppings should be of the finest manurial value.

If this turns out to be correct, then plants often possess very elaborate arrangements both for dealing with atmospheric dust and for turning dangerous disease germs into a useful sort of plant food.

1 Nestler, Lindau, Freeman.

2 Thomas.

3 Kosaroff.

4 Hildebrandt.

6 Freidenfeldt.

10 Peirce.

13 Adamovic.

18 Boodle.

5 Journ. R. Hort. Soc, April 1902, p. 900.

${ }^{7}$ and ${ }^{8}$ Hansgirg. 9 Warming.

11 Cieslar. 12 Krasan.

14 Von Wettstein. ${ }^{15}$ Knuth.

17 Parkin and Pearson.

18 Kirchner, Low, and Schroter.

20 Katic, Koning, and Heinsius.

22 Burkill.

24 Goebel, Groom.

27 Tshirch, Wildt.

23 Weisse, Yule, Shull.

25 Ursprung.

28 Bicher.

19 Hesselmann.

${ }^{21}$ Went.

26 Henslow, Hartig.

28 Macnaghten-Jones. 


\section{CHAPTER XVII}

\section{VEGETABLE AND ANIMAL}

Betwixt the vegetable and animal worlds there is, always and everywhere, a very close connection.

One finds in the history of nations many examples of the effect that forests have had upon their history. In the time of Charles the Great, for example, the boundary of German and Slav in Europe coincided with the limits of the pine forest. The Germans possessed cattle and so required oak or other deciduous woods, leaving the great pine forests to the Slav. ${ }^{1}$ The early history of Britain was much influenced by the great forests of the Sussex weald and of central England, which remained a safe refuge for outlaws and masterless men until well into the middle ages.*

Man has, of course, transformed and entirely altered the world's vegetation in all civilised countries and even in others, for the most savage tribes burn the woods. Even the distribution of plants in the Alps is altered by human agency, for the different habits and customs of Italian and German peasants have produced quite a different attitude for many of the flowering plants on the different sides of those mountains.

As of course every one knows, all animals live upon some sort of vegetable food, either directly or indirectly.

Plants try to protect themselves against being devoured by all sorts of ingenious contrivances, such as thorns and spines, bitter or poisonous secretions, milky juice or latex, and the like. 


\section{Vegetable and Animal}

Sometimes, as we have seen, they are so like the stones or sand of the desert that they cannot be easily picked out ; sometimes also plants which are quite good to eat so resemble others which are not, that they are left alone by grazing animals.

The white dead nettle (Lamium album) and the stinging nettle is the example which is most often selected, though recently some doubt has been expressed about the actuality of the protection. It is a fact, however, that a patch of stinging nettles will hold their own for some fifty years at least in a park regularly grazed by cattle. (Their favourite position is in the richly manured soil under the shade of the widely spread foliage of an oak or other large tree.)

So that cattle do not habitually eat nettles. But it is not certain that they would in any case devour the dead nettle, for the Labiate order is not a favourite on account of its strong scent.

Both stinging and dead nettles are most often found by hedges and roadsides. There they have to maintain themselves against boys and girls, who are the most destructive of all animals. A rhinoceros will, in a fit of fury and bad temper, trample down and break into tiny pieces large bushes of acacia. Man, in this undeveloped stage, is also capable of the wanton destruction of vegetables, but apparently no other animal.

A very interesting puzzle in mimicry is the fact that in Australia some of the parasitic Loranthus, allied to our mistletoe, closely resemble in leaf the acacias upon which they grow. This was discovered by Drummond and has been confirmed by Mr. Moore. The ordinary leaves of most acacias are utterly unlike those of the ordinary Loranthus. Mr. Moore states that camels browse upon the Loranthus, but do not touch the acacia leaves. ${ }^{2}$ 


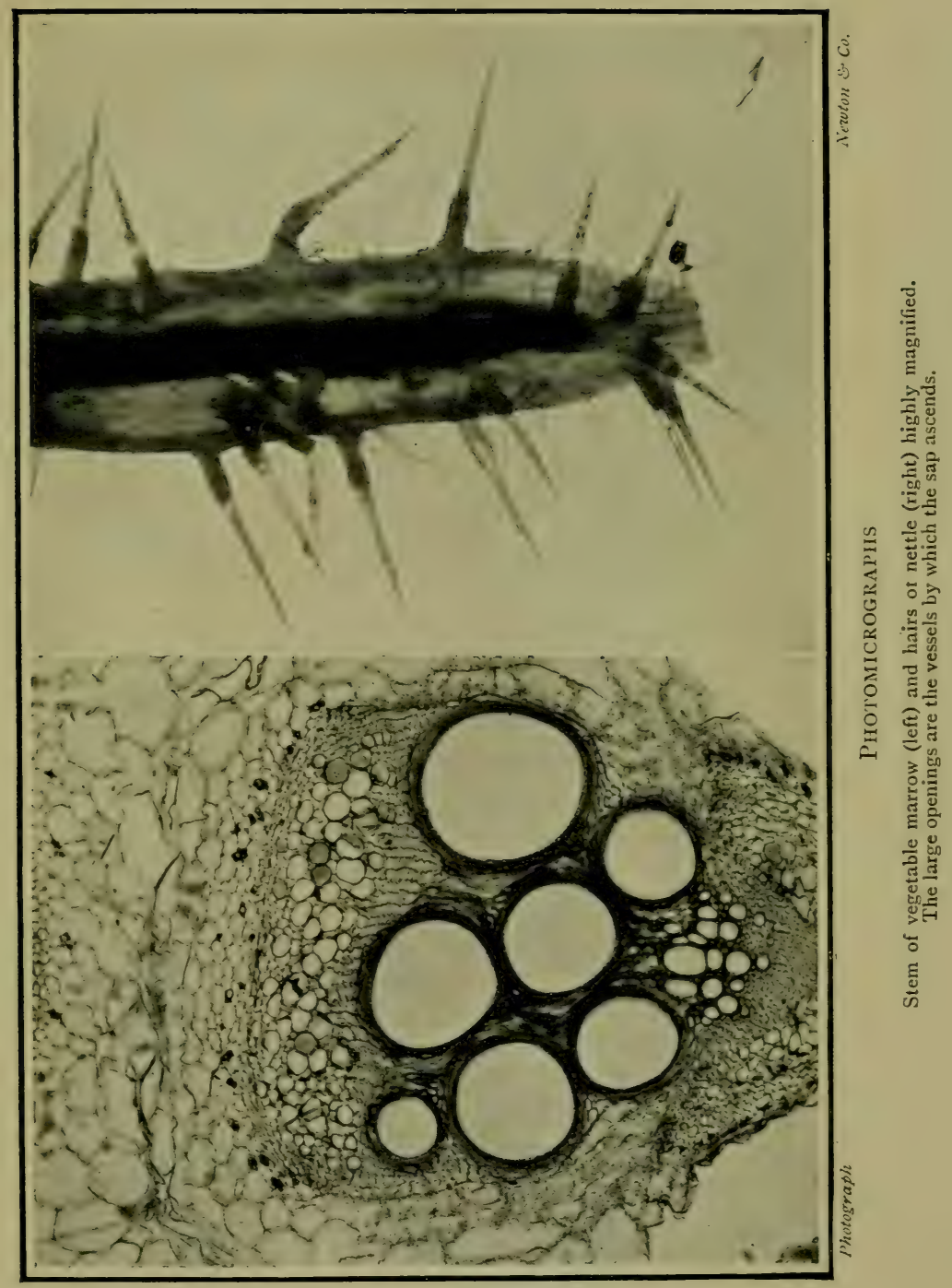





\section{Vegetable and Animal}

The camel is not indigenous in Australia, and one can only trust that the kangaroo is so foolish as not to be able to pick out the nutritious Loranthus leaves from amongst the astringent acacia foliage.

The resemblance of some insects when at rest to a leaf or a stick is most remarkable. This is an old story, and in every sense, for it was Commerson in the eighteenth century who first called attention to the exact leaf-like pattern of some of the creatures found by him. Moreover, an insect apparently allied to our cockroaches existed in the Carboniferous period, whose wings in the shape and veining closely copy the leaflets of a common fossil (Neuropteris) of that time. ${ }^{3}$

There is a difficulty often brought up against the usual theory about such mimetic resemblances, which is that in the early stages, before the similarity was perfect, they could not possibly be of any use. That objection, however, is not so much felt by field naturalists as by those who conduct their inquiries in a public library.

In going through the dry, yellowish-brown grass near Lake Albert Edward Nyanza, I rose a grasshopper-like creature which alighted on a withered grass haulm and was at once invisible. Its mode of resting aped exactly the hang of the withered spikelets, and the colour of such part of its wings and legs as were exposed were precisely that of the withered vegetation.

Such incipient colour resemblances and imperfect mimicries are very abundant.

A far more important point, however, is the close and intimate relation which exists between animals and plants when considered as diners and dinners.

It is not often realised how greatly the animal world stimulates and improves the vegetation. It is not only man that can make two blades of grass develop where only one had grown before. Worms which feed upon 


\section{Vegetable and Animal}

dead vegetable matter improve the soil by their casts. This, then, can bear more grass which will enable a larger worm population to live.

Living as we do in a country which is mostly good loam and never destitute of "soil," it is not easy to realise how different is the state of an unfortunate vegetable doomed to languish in a purely "mineral" earth, where there is neither leaf mould nor dead organic matter.

In such open floras, the occasional visit of an animal will be extremely beneficial, even if it does devour half the year's foliage.

In the open floras of the Arctic regions, of scrubs and of dry tropical countries as well as in the peatmosses of this country, this good influence of animals has been pointed out. Mr. Sewell has shown that an abundance of rich grasses and unusual plants characterises those islands in Lapland where the gulls breed and where guano is abundant.

Middendorf has a graphic picture of the desolation and dried up appearance of the Arctic Tundra in Taimyrland. Here and there, in the monotony of its brownish-yellow surface, the eye discovers at once patches of a bright refreshing green. Such spots are invariably near the burrows of the Arctic fox, or where the Samoyeds have folded their reindeer. ${ }^{4}$

So also in the dreary and dry scrub which covers the arid Patagonian tableland, vivid patches of green grass are found only at those places to which the guanaco habitually resorts.

Something of the same kind is said to be visible in India where old sheep-folds or cattle pens may remain green when the ordinary open flora has withered to nothing.

Even in Scotland, when walking over the dark-brown I 98 


\section{Vegetable and Animal}

heather moors of Kirkconnel Moss (near Dumfries) and Flanders Moss (near Stirling), one comes, here and there, upon a small, dense tussock of thick grass, which is bright fresh green and as different as possible from the neighbouring vegetation. Moreover, the grasses of these tufts are not moorland species, but regular pasture or roadside forms.

One finds at such places that the gulls are nesting on this part of the moor, and these patches have been naturally guanoed by them. Indeed it is by no means unlikely that sheep could change moorland into good grass simply by close grazing, and provided only the ground is dry enough. On the other hand what havoc has been caused in Greece, Spain, and even in our own moorlands by the ravages of sheep, goats, and cattle!

The result of their hunger is to leave only a curious collection of poisonous, strongly smelling or otherwise inedible shrubs instead of pine woods and rich grass pastures.

In Australia, which has a flora of a very ancient type, there are many poisonous plants. Many animals are killed every year by the deadly Mirbelia and Gastrolobium. Even strong oxen will die in six hours after eating the leaves. Dogs which eat the flesh of the cattle may also be poisoned by it. Pigeons, however, eat the seeds and are not injured, and when such birds are cooked, they are quite good to eat. ${ }^{5}$ Even in Britain many really poisonous plants still exist. In lochs, marshes, and elsewhere, the poisonous Equisetums (palustre, silvestre, and arvense) are by no means rare. These species had ancestors in the coal-measure days, who no doubt protected themselves against whatever animal ate their foliage by similar poisons.

The wild animals of a country, or even domestic cattle, when allowed to graze freely with an old beast 


\section{Vegetable and Animal}

amongst them seem to be seldom or never poisoned. So that there must be some educational influence at work; practical botanical knowledge is somehow acquired by the growing calf.

One very curious instance of the close relation of plants and insects is found in certain fungi. There are no less than 708 species of fungi which grow on the droppings of herbivorous animals, 45 species on that of carnivore, and four on that of reptiles. ${ }^{6} \quad$ The commonest (Ascobolus) forms the little brown-red saucers which cover such surfaces. The tiny transparent spores are squeezed or darted out of the fungus and fall on the grass leaves, to which they at once adhere and become cemented. They are eaten with the grass by cattle, and pass uninjured through its complex digestive system.

The adaptations of special insects to the times and seasons of plant life are very remarkable. The spruce gall insect, e.g., forms those small, withered-looking galls which are exactly like diseased first year's cones, and which are very common on spruce twigs. There are five forms of the insect. The "foundress" wingless females produce the galls. Their larvæ live in them but eventually get wings, and as "colonisers" fly to the larch or pine, where they winter in crevices of the bark; their children live on the larch leaves or pine needles, and lay eggs which become male and female winged insects. The females return to the spruce and their progeny are "foundresses." 7 The changes are in reality even more complex than these.

This insect continues on the spruce, but also has the chance of using two other trees.

It is, however, when one tries to unravel the manifold relations of a green-fly to the plant and animal world that one begins to realise something of the way in which Nature works. The aphis or green-fly of the hawthorn 


\section{Vegetable and Animal}

has no real friend. Its children are carried away by ants, who probably neglect them ; other ants come and "milk" the aphis of its drop of honey. Wasps, birds, and several beetles eat the aphis. There is a fungus which forms a white threadwork growing over the hawthorn, and this also attacks and kills the aphis. Another beetle feeds upon the fungus. ${ }^{8}$ Yet the aphis is not at all likely to die out, for its progeny are so abundant that it can withstand all its enemies and even such a bird population as we have in Britain.

Certain fungi (Mucor exitiosus) also invade the bodies of locusts, but unfortunately it has not yet been found possible to use this fungus to destroy that dangerous South African and South American pest. ${ }^{9}$

Many well-known and often described plants do prey upon insects, and indeed live mainly by them. The butterwort, whose leaves roll inwards over the midges stuck on them; the pretty little red sundew, with its deadly tentacles; Venus' fly-trap, which closes and imprisons its fly visitors, are too well known to be again treated of here. But there are certain complex cruelties connected with Nepenthes bicalcarata of which the reader may not be aware.

There are two remarkable spurs which project or curve inwards over its pitcher, and which have been compared to the fangs of a snake ready to strike.

These have intrigued naturalists who could give no explanation of them. Burbidge suggested that they would prevent the Kobold monkey from scooping out the insects with its little hand or fingers, but this was not accepted by every one. But Herr Behnick states that honey is secreted at the top of these spurs. In consequence ants climb up the spurs and so jostle and crowd one another that many are pushed off the smooth, slippery surface and drop into the pitcher, where 


\section{Vegetable and Animal}

they are drowned and digested without any hope of escape.

Plants are seldom guilty of stupid, senseless cruelty. This Nepenthes is on the same moral scale as a fisherman, but one cannot say the same of Araujia sericifera (see p. 150). The way in which all sorts of insects are employed to carry pollen benefits both themselves, other animals, and the plant-world.

The migrations of birds depend upon the first appearance of the insect swarms on which they feed. So in southerly places, and in the lowlands, swallows and other migrants arrive earlier in the season than in the north and alpine districts.

Nor is it only insects that are used in pollination; many of the finest flowers in subtropical and tropical lands are haunted by the brilliant, flashing little sunbirds and humming-birds. Even in this country one may see an occasional sparrow picking at the heads of ragweed. Yet there is a great difference between any ordinary flower and the flaming scarlet blossoms, with curved narrow tubes, of some lobelias and salvias. A sun-bird has a thin, narrow, and curved beak, and if his wife is responsible for his gorgeous clothing, its colour is a good example of her taste. These jewels of nature are as different as possible from the ordinary bird which was its ancestor, and which picked insects out of honey. Bats, kangaroos, and small mammals are also used to carry pollen according to report.

Another way in which the animal enemies of plants are utilised by them is in the carrying about of fruits and seeds.

The Harpagophytum and Martynia of South Africa and other fruits with ingenious spiny, hooked or sticky attachments have also been a favourite and familiar part of the botany of several years ago. 


\section{Vegetable and Animal}

We shall only mention Rafflesia patma of Java, for its method of seed distribution is ambitious and yet very simple. This is a parasite which grows in the forests on the projecting roots of certain vines (Cissus). The enormous flowers (I 8 inches across) are conspicuous enough in the dark atmosphere of the jungle. The plant consists of practically nothing except this flower and a short root which burrows into the Cissus and extracts all the nourishment required.

When the huge flower decays, it forms a sticky pulpy mass "like broth," and full of seeds. An elephant strolling through the forest will step in it, and will, of course, naturally scrape its feet against the next conveniently projecting Cissus root which it happens to encounter. ${ }^{10}$ The seed will therefore have a good chance of establishing itself on it.

Perhaps the next most interesting example is formed by those plants which employ ants to carry their seeds from one place to another.

It is only but recently, in consequence of the minute observations of Sernander, that we have begun to realise how important these insects may be. To one nest it was found that 366 seeds were brought in during nineteen hours ( 156 of Melica, 69 Cowwheat, 3 I Luzula, 28 Hepatica, 25 Carex pilosa, \&c.). Along a path used by the ants he marked out a square yard, and found that twenty-eight seeds were dropped in it. Some of the seeds were carried seventy yards and more.

It is no doubt in order to induce the ants to carry them that one finds these curious little swellings on the seeds of Chionodoxa (Glory-of-the-snow) and the snowdrop, or the little ridge at the foot of the fruit of the corn bluebottle (Centaurea cyanus). The unusual fact that the white dead nettle secretes sugar after the petals have fallen off is at once understood by its being 


\section{Vegetable and Animal}

found that an ant came to one of these fruits for sugar and carried off a seed. The oily seedcoat of the wild garlic (Allium ursinum) or of the Hepatica also attracts the ants. ${ }^{11}$

Such characters might very easily be supposed useless or ornamental, yet they are vital to the wide distribution of the species. Perhaps the fact (if true) that the snowdrop is not really a British plant may be best explained by the absence or comparative scarcity of the ants which carry its seed. Its distribution in Europe follows that of the oak or mixed forests everywhere.

But ants and mites are far too important to leave to the end of a chapter.

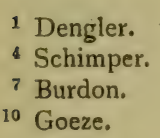

1 Dengler.

7 Burdon.

${ }^{10}$ Goeze.
2 Moore.

${ }^{5}$ Holmes.

8 Schneider.

11 Weiss, Sernander.
3 Handlirsch.

6 Massee and Salmon.

9 Lindau. 


\section{CHAPTER XVIII}

\section{ANTS AND MITES}

Most of the ordinary forest trees-lime, beech, ash, sycamore, and oak - are remarkable for the curious little hairy pockets which are to be found generally at the forkings of the veins on the under surface.

There is a great deal of variety in the different leaves even of the same tree; in some the tuft of hairs is very conspicuous, and in others it will be scarcely visible at all.

It is interesting to stir up these little pockets with a pin whilst watching them through a strong lens, for then the horrible little mites which reside there come scurrying out of their caverns and run about wildly. The colour of these mites varies, for there are many distinct kinds; but as a rule it seems to be usually the same as that of the hairs which mark their dwelling-place.

The structure of a comfortable residence in the occupation of a thriving mite-family is not very easy to follow without very careful dissection, but one might say roughly that it is a winding cavern improvised between the fork of two veins and extending some way back into the tissue of the leaf. The narrow entrance is marked by the fringe of hairs already mentioned.

These mites are said to wander about over the leaf at night feeding on fungus spores, bacteria, and the like, and they certainly retreat into their little caverns during the heat of the day (see p. 193).

As a rule every vein-fork possesses a few hairs and a sort of fold or hollow, but those which are seats of the 


\section{Ants and Mites}

mites have many hairs and a comparatively large but variable cavern. (When we say large, we mean about one-sixth of an inch.)

So the interesting question arises, are the effects of mite scratchings and secretions inherited? The formation of hairs and the same sort of pocketing of leaf tissue is one of the commonest characters of galls. If the hairy pockets appear on a young leaf which has never seen a mite, then there is an inheritance of these effects.

There are other cases just as interesting and on which a violent controversy has been carried on. The most remarkable of all concerns a certain genus of South American plants called Tococa, and which lives in the Amazon valley.

The traveller Spruce, forty years ago, wrote an interesting paper about Tococa, of which he knew at least nineteen species in the Amazon valley. These shrubs, with one exception, grow in that part of the valley which is regularly overflowed for months together by the annual inundation of the "white" or silt-laden water.

They are remarkable for a very curious swollen leafstalk. This expanded part is hollow and is inhabited by fierce ants, which swarm out and bite severely any traveller that meddles with the shrubs. Indeed Spruce found it very difficult to get satisfactory specimens of Tococa in consequence of this bodyguard of ants. He points out also that during the annual floods, the ants are saved by these hollow residences, which are often above the level of the water.

But the one species which is found outside the inundation level has no such swellings and apparently no bodyguard of ants. In the original paper Spruce goes on to say that he had occasionally found in several of the inundated species leaf-stalks which were not inhabited by ants but which nevertheless showed the character- 


\section{Ants and Mites}

istic swelling, though not in such a pronounced form as was usual. He draws the obvious common-sense conclusion that this rare characteristic of a swollen petiole probably owes its origin to the visits of ants continued for untold generations, until it has become a characteristic of the species.

The well-known scientific society before whom the paper was laid, asked him to take out these conclusions of his, which were of course the really interesting and valuable part of the paper. Spruce never did so, and it has only appeared in a recently published book.

It is difficult to understand why this course was taken; even if Spruce had been proved wrong by other observations, his conclusions were a valuable piece of evidence which could have been tested by other naturalists.

But then and even to-day there is a dogma which says that mutilations can never be inherited. Only to-day, after forty years, there are but few who believe it as firmly as was the case at that time. Spruce not unnaturally seems to have been disheartened and disgusted by this affair. Now of course we know of hundreds of ant plants which not only shelter swarms of ferocious ants but provide them with board as well as lodging.

Some of these ant-plants produce sugary secretions, others "food-bodies," which contain proteids. The reader will find much of great interest about ant-plants in Bates' "Naturalist on the River Amazon."

Perhaps the most striking of these plants are certain acacias which have huge swollen stipule-thorns which are hollow and form the residence. A minute hole gives entrance and exit to the ants. There is also the Imbauba or Cecropia, which has hollow internodes. At one point in the stem there is a very thin weak spot just towards 


\section{Ants and Mites}

the top of the internode, and the ants gnaw an opening for themselves at this spot.

In Malaya there are two species of ferns (Polypodium) which grow on tree branches. Their stems or rhizomes, which are large and fleshy, are traversed by irregular winding passages in which live multitudes of ants. Now when this fern is grown so that no ants can reach it, it is said still to form such passages, though by no means on so extensive a scale. In Malaya the galleries are partly excavated by the ants themselves. ${ }^{1}$

It is probably for the sake of ants that one finds, outside the flowers, honey-glands or nectaries in many of our English plants (Vicia stipules, \&c.). ${ }^{2}$ In one of the rubber trees (Hevea) such nectaries occur in the budscales, so that, when the buds are unfolding and the foliage is still young and tender, ants come and swarm about the buds. But as soon as the leaves are fully formed, two honey-glands at the base of each leaf continue to keep these formidable insects busy and always running over the foliage. ${ }^{3}$

One might say that it is ants' inhumanity to ants that makes countless thousands mourn, for it is other insects of their own kind that these fierce bodyguards are intended to keep away.

The worst are those curious, leaf-cutting forms which every South American plantation-owner knows far too well. An army of them will at once proceed to his cocoa plantation; each insect will then solemnly and slowly cut out a neat circle of leaf substance. They stand on the leaf and cut round, keeping on the centre of the circle, which is said to be almost as exact as if made with a pair of compasses. They will then form a procession towards home, holding the circle of leaf like an umbrella over their heads.

Now comes, however, the really astonishing part of 208 


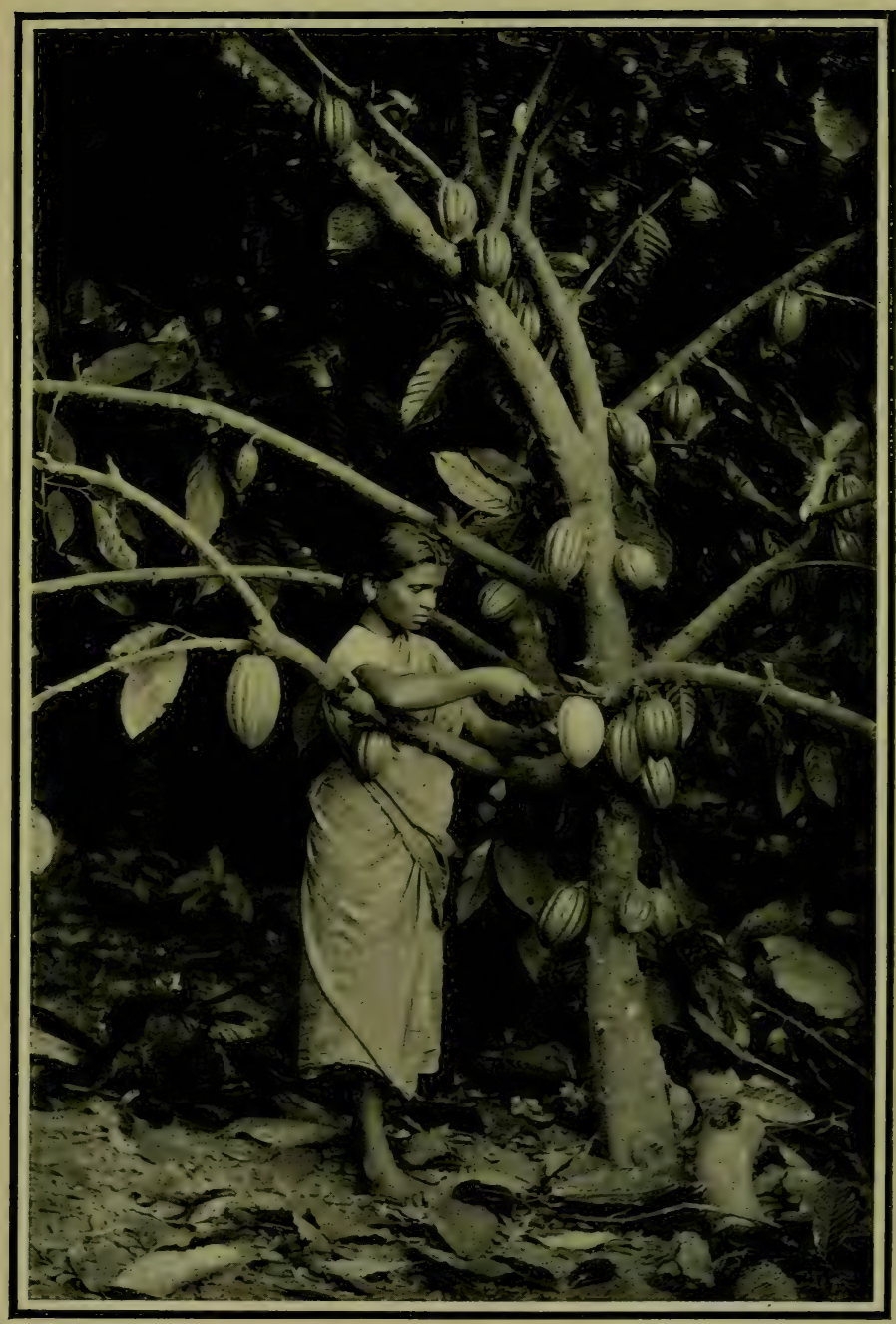

Photographed by]

[Skeen \& Co., Ceylon

Plucking Cocoa Pods

The operation is a difficult one, as the fruit is extremely short-stalked, and the buds on its stalk must not be injured. 



\section{Ants and Mites}

the story. Those who are qualified to judge of these matters seem to have been convinced that there is no doubt as to the truth of what follows.

Having arrived home, the ants masticate the leafpieces and place them in prepared beds in their underground galleries. A peculiar fungus soon grows upon these beds, and is kept almost like a velvet sward by these gardener-ants, who nibble off the fruits as soon as they appear. It is upon this fungus that the ants live.

These proceedings are far more intelligent even than the Palestine ants, who collect corn and bite off the radicles or root-tips when the grain begins to germinate, apparently because they know that the grain will spoil if allowed to sprout.

But Dr. Ule, in his recent exploration of the Amazon valley, has discovered some still more remarkable facts about these uncanny creatures.

All over the Amazon valley and Guiana, and even up to about 3000 feet altitude on the mountains, curious bunches of green herbage rather like storks' nests may be seen on the trees.

These are again the work of two kinds of ants. They collect the seeds of certain plants and carry them to a fork in the branches or a crack in the bark ; they then bring earth and surround the seeds with it. In that moist and genial climate the seed germinates, and soon forms an ant-garden in which they make their nests. They are protected by the luxuriant growth of the plants both from violent rain-storms and from the strong rays of the tropical sun.

The plants which they use are some seven or eight in number, and are widely distributed in the Amazons, though almost invariably in these gardens. Two only of these plants occur elsewhere, but on the ground and not apparently on the bark of trees. They consist of 


\section{Ants and Mites}

certain grasses, an Anthurium, Philodendron, Aechmea, Peperomia, Phyllocactus, \&c.

Dr. Ule says that the gardens are "geziichtet" or looked after by the ants which make them, and the peculiar growth of the plants increases the amount of soil. Under the leafy shade of their own plantations these astonishing insects enjoy a safe and comfortable home. ${ }^{4}$

It is indeed fortunate that man has had a fair start in the business of replenishing the earth and subduing it, for indeed these insects seem really capable of anything.
${ }^{1}$ Japp.
2 Haupt.
${ }^{3}$ Parkin.
4 Ule. 


\section{CHAPTER XIX}

\section{ELECTRICITY-RADIUM-, N-, AND X-RAYS}

OF late years our knowledge of the world's working has been raised to another new and more advanced level both by the discovery of radium-rays and other mysterious emanations, and by a more practical acquaintance with electrical engineering.

Unfortunately this is not a time in which it is at all safe to speak of these discoveries, for, like people who are a little out of breath from climbing to the top of a mountain ridge, our pioneers are not yet agreed as to the meaning of the new scenery, nor as to how it fits in with our older maps of the country.

The exact nature of electricity is still a mystery, and this of course prevents any satisfactory explanation of its effects.

It has been shown that the electrical potential of the atmosphere increases with the height above the earth. When rain falls, the electric potential of the earth becomes very much greater. At the tower of Meudon, near Paris, heavy rain increased the electric potential, which was from 600 to 800 volts, to as much as $\mathrm{I} 2,000$ to $\mathrm{I} 5,000$ volts.*

So it is supposed that the subsoil water of the earth must have a high electric potential, perhaps giving rise to the mysterious earth-currents which affect our telephones. If that is so, one would expect feeble electric currents to be passing up living plants from the root

$$
\text { * Compare " Electricity of To-day." }
$$




\section{Electricity-Radium-, N-, and X-rays}

to the stem and leaves, where there may be discharges into the atmosphere.

There is some support for this theory, as one can at once prove by directly testing living plants. When the ascent of sap is slow and feeble the current may be imperceptible, but a distinct though feeble current is usually to be found when the sap is flowing vigorously.

Several authors have found that currents which are made to pass in the reverse way, that is, from the top of the stem towards its root, produce injury, whilst those in the direction of the sap are distinctly favourable.

That feeble currents of electricity stimulate germination and the growth and vigour of a plant seems to be admitted by all authorities. Indeed it has been shown that a weak electric current stimulates the streaming movements of protoplasm, whilst a strong current has the opposite effect and retards it. ${ }^{1}$

So also with various specially sensitive plants. Dr. Bose has obtained reactions which strangely resemble what happens when animal protoplasm or even muscles are similarly stimulated. The stamens of certain Centaureas contract, just as they do when touched by an insect's foot or a needle. A piece of convolvulus stem contracted about three per cent. of its length under small shocks at five seconds interval. For other examples one must refer to his book upon the subject.

There is also plenty of evidence to show that electric currents help in assimilation. The Canadian waterweed (Elodea) has often been used to test this point. By passing an electric current through the water in which it is growing, the number of air-bubbles given off per minute is distinctly increased, and, if one is careful to keep the current weak enough, the plant is not injured. But it is very easy to tire it out by overstimulation and so kill it by electrocution. ${ }^{2}$ 


\section{Electricity-Radium-, N-, and X-rays}

Pollacci's careful experiments with flowering plants also led him to believe that plants are distinctly invigorated and assimilate more under electric currents. His statement that plants can form sugar in the dark when so stimulated has not yet been confirmed by other observers.

The effect of electric currents on roots is still very obscure. When a current is passed through water in which there are seedlings growing, the rootlets often turn towards the positive pole. This is supposed to be due to some kind of electrolysis, injurious products accumulate at this pole, and the turning of the little roots towards them may be compared to the usual bending of injured roots towards the source of irritation. ${ }^{2} \quad$ This would mean that the electric current may in itself have no effect upon them.

But many ingenious and interesting experiments have shown that it is possible to use electricity in order to help to accelerate the growth of plants.

A Scotchman, Maimberg, tried to stimulate two myrtle bushes in 1746 , but his results (the first to be attempted) were not conclusive.

Next came the Abbé Nollet, who grew pot plants on an iron tray supported by silk threads. The plants so isolated were charged by means of an electrostatic induction machine. Both maize and mustard seed germinated much more rapidly.

Bertholet set up a tall pillar with cupped points, so collecting atmospheric electricity, which was conducted into a series of plants at the base of the pole. Another ingenious system consists in sinking plates of copper and zinc in the soil of a greenhouse, and connecting them by a wire. Speschnew, a Russian, invented this method, which has also been followed by Priestley in $1906 .^{3}$

Others have used an arrangement of wires supported 


\section{Electricity-Radium-, N-, and X-rays}

on cross bars above the growing plants. These wires were charged with electricity by means of a dynamo. Others again have passed (electrostatic) currents through the earth in which the plants were growing. Lemström, who was successful with this method, supposed that the soil bacteria were invigorated and wakened up by the current, and that their activity helped the plants.

On the other hand, a recent observer has declared that continuous electric currents are distinctly injurious. ${ }^{4}$

For most of these details, we have to thank the late $\mathrm{Mr}$. Thwaite, whose interesting paper (Journal of the Royal Horticultural Society, June I908) contains full details of his own apparatus for electrifying plants.

The following table (also from results cited by him) would seem to show that there is really some practical benefit to be gained.

\begin{tabular}{|c|c|c|c|c|c|c|}
\hline & & & Author. & $\begin{array}{l}\text { Increase } \\
\text { per Cent. }\end{array}$ & Quality. & $\begin{array}{c}\text { Sugar } \\
\text { per Cent. }\end{array}$ \\
\hline Wheat & & . & Newman & 29 to 39 & Improved & ... \\
\hline Oats. & • & - & Lemström & 40.7 & ... & ... \\
\hline Rye. & . & - & , & 19.5 & ... & ... \\
\hline Strawberric & & - & ", & 37 to 50 & $\cdots$ & $\cdots$ \\
\hline ", & & - & Newman & $38^{36}$ & Improved & 14.5 \\
\hline Potatoes & - & - & $\begin{array}{l}\text { Lemstrom } \\
\text { Lemström }\end{array}$ & $\begin{array}{c}13.0-31 \\
12.3\end{array}$ & $\cdots$ & $\cdots$ \\
\hline $\begin{array}{c}\text { Carrots } \\
\text {,g }\end{array}$ & . & : & Gloucester Expmts. & 50 & $\begin{array}{l}\cdots \\
\cdots\end{array}$ & $\begin{array}{l}\cdots \\
\ldots\end{array}$ \\
\hline Beet. . & - & - & $"$ & 33 & Improved & I.I \\
\hline Cucumber . & & - & Newman & I7 & $\cdots$ & $\cdots$ \\
\hline
\end{tabular}

Most of these experiments seem to have been carried out with overhead wires.

Priestley tried the Speschnew system of copper and zinc plates with beans, and found that the average volume of the bean increased from $\mathrm{I} .5 \mathrm{ccm}$. to $2 \mathrm{ccm}$. (.09 I 5 to .I 22 cubic inch), whilst the average weight increased from I.7 I gr. to $2.26 \mathrm{gr}$. ( 27 grains to 34.7 grains). 


\section{Electricity-Radium-, N-, and X-rays}

These experiments are of course distinctly encouraging, but whether the cost of producing even a 50 per cent. increase of the crop will prove economical or nct, is a question which can only be solved by many trials.

There is also the danger of electrocution. In America, strong electric currents are used to destroy the railway weeds (see p. 258). Continuous electric currents for street cars have also been found to destroy trees, especially in wet weather. Alternating currents seem to stimulate the growth of trees, but this is sometimes injurious. $^{3}$

In America, where long distance transmission lines of high voltage are common enough, secondary induction currents must often be set up in any trees which happen to be growing close to the wires. That this is really the case seems certain from Major Squiers' experiment. $\mathrm{He}$ found that on attaching a telephone to the trunk of any tree within a hundred yards of such a line, a distinct note could be heard due to the induced current. These trees had been "singing" the same note without any rest for years ever since the line had been built.*

When an electric discharge is passed through ordinary air, both nitrogen and hydrogen are affected, nitrous and nitric acid are formed, and also peroxide of hydrogen. It is probably these substances which are responsible for the destruction of bacteria, ${ }^{5}$ but ozone is also produced, which is again a bactericide. Ozone affects yeast injuriously, and also those ferments or enzymes which play an important part in every physiological process in plant life. ${ }^{6}$

Pollacci has suggested that the process of assimilation depends upon electrical currents in the leaves, and it is, as we have seen, a fact that peroxide of hydrogen is really formed by electric discharges in the atmosphere.

* See "Romance of Plant Life," p. 198. 


\section{Electricity-Radium-, $\mathrm{N}-$, and $\mathrm{X}$-rays}

The electric light can be and is often used instead of sunlight, and the results are sometimes of great value financially. Lilac can be made to flower ten days sooner by using arc-lamps.

Semon managed to get certain acacia seedlings to do with a twelve-hour instead of a twenty-four hour day by electric light cultivation. A regular rhythm could be induced corresponding to six hours instead of twelve hours of light. ${ }^{8}$

We have already shown how interesting and practically useful are the points connected with electric light and electric stimulus on vegetable life, and it is necessary to say something about the effects of radiumand Röntgen-rays.

This need not take up too much space, for, so far as is now known, such rays seem to be always either harmful or without any influence whatever. Bacteria are killed, growth is prevented, and the germination of seeds is hindered by them. The nucleus of the cell is also said to be affected injuriously. ${ }^{9}$

On the other hand it is said that at first there may be a slight increase in growth or favourable effect under either Röntgen- or radium-rays, which is soon followed by a greatly retarded or complete cessation of growth. This is, however, exactly what is found in the case of most poisons (see Chap. XXIX.). Bacterial spores are killed by radium in seventy-two hours and vaccine in twentytwo hours. ${ }^{10}$

But after such micro-organisms have been destroyed, that is, after 24 to I 20 hours' exposure, it is found that they themselves, though dead, become radiant. A feeble radio-activity is also said to be exhibited by freshly gathered vegetables, but only lasts for at most four days. ${ }^{11}$

Recently Dr. Russell discovered that photographic plates can be affected in the dark by a great variety of 


\section{Electricity-Radium-, N-, and X-rays}

vegetable substances. Wood, leaves, seeds, bulbs, blotting-paper, as well as coal, resin, and jet, could all take photographs of themselves. The exposure varies from a few minutes to eighteen hours, and the only necessity is to make sure that the material is absolutely dry. He is careful, however, to point out that this effect is probably due not to radio-activity but to a vapour of resin. ${ }^{12}$

There is also a mystery connected with what are called $\mathrm{N}$-rays. These seem to be only produced by fresh and living protoplasm, for when the plants have been chloroformed they do not give out $\mathrm{N}$-rays. ${ }^{13}$

The botany of to-day contains therefore many interesting problems in physics which still await a proper explanation.

1 Ewart. ${ }^{2}$ Pollacci, Ewart and Bayliss, Plowman.

4 Lowenherz. ${ }^{5}$ Foulerton and Kellas.

7 Polacci. $\quad{ }^{8}$ Molisch, (Dorn, Baumann, Valentiner).

9 Dauphin and Green, Koernicke, Dixon and Whigham.

${ }^{10}$ Green. $\quad{ }^{11}$ Tommasina. $\quad 12$ Russell.

${ }^{3}$ Stone.

${ }^{6}$ Sigmund.

${ }^{13}$ Meyer. 


\section{CHAPTER XX}

THE ORIGIN OF OUR BRITISH FLORA

WhAT is known of the European flora before the great series of Ice Ages had entirely altered its character is in a way satisfactory and yet a little bewildering.

In Eocene, Miocene, and Pliocene times in France, a very strange mixture of plants have been recognised. In the same stratum there may occur two species which are now separated by, for instance, the entire width of Europe and Asia, or what is much more difficult to understand, two forms which we now consider characteristic of temperate and subtropical climates respectively, and yet which had, in the Ardéche, been involved in the same volcanic eruption and whose fossil leaves are found side by side. ${ }^{1}$

It is supposed that these French deposits show a distinct change of climate. In the Upper Pliocene they seem to suggest that the Great Ice Age is already looming in the distant future. But on the whole, M. Laurent refers to the fertile valleys of the Caucasus as explaining this mixture of different vegetations in the flora of Cordagne and Charay at that very ancient date.

When the glaciers invaded Northern France and covered the whole of North-western Europe, from Norfolk upwards, in a winding sheet of snow, the ancient European flora was of course in large part destroyed.

It seems that even before those days many species and perhaps the present kind of temperate deciduous woodlands were to be found on the Pyrenees, Alps, and 2 I 8 


\section{The Origin of our British Flora}

Caucasus. In Eastern North America, Greenland and Europe, the trees were also closely allied to one another.

The Alps possessed already such modern flowers as Campanulas, Saxifrages, Primulas, Veronicas, Androsace, and Rhododendrons, and though, as is the case to-day, each mountain group had a flora of its own, yet certain species wandered from mountain to mountain keeping to the higher summits. ${ }^{2}$

Even to-day in Japan and East Asia one may discover in the high alpine regions a few Scotch mountain plants such as Phleum alpinum, Oxyria, Sibbaldia, and the common butterwort. ${ }^{3}$

There are instances which show how after the great ice invasion the same species has been separated and confined in two distinct and distant mountain systems. Thus Erigeron frigidus grows in the Sierra Nevada of Spain and also in South-west Persia; Scutellaria orientalis is found only in Spain and in Asia Minor; Saponaria glutinosa in Spain and in the Caucasus. This shows the ruthless division of kindred by the projecting fingers of the northern ice. ${ }^{4}$

But just as interesting are those cases in which a number of little special forms of one genus belong to the various mountain ranges.

Cardamine shows this very beautifully, for there are forms from the Pyrenees (I sp.), Alps (4 sp.), Apennines (3 sp.), Caucasus (6 sp.), Himalayas ( $7 \mathrm{sp}$.$) , and North$ America. Besides these our own cuckoo-flower ranges all round the North Pole and through the Arctic regions, whilst C. impatiens may be found anywhere from Scotland to the Pyrenees, and all the way to Japan.

Many of these northern alpine and subalpine species have even invaded the highest summits of tropical Africa, such as Ruwenzori, and even Kenia and Kilimanjaro, whilst others have outliers which occur in the 


\section{The Origin of our British Flora}

Rocky Mountains and the Andes (Luzula spicata, Cerastium alpinum).

The clearest idea that one can obtain therefore from recent researches is that of a huge Northern Drift overshadowing the northern hemisphere, and dividing off groups of separate mountain chains, so producing an infinity of subtropical, temperate, and cold climates, all separated from each other, and in each of which the formation of new species was proceeding rapidly.

The Spanish peninsula seems to have been specially isolated, and in consequence we find its flora to-day very rich in peculiar or endemic species. For the British islands the problems are not nearly so complex as for Europe generally. There are some four or five American-Irish plants and, chiefly in the extreme south of England, the Cornish heath, and a few others which are allied to the Portuguese-Spanish flora. But the British flora, as a whole, is the north temperate European flora.

When the Ice Age began to vanish away, when glaciers shrunk, and when the accumulated snowfields of centuries dissipated themselves in those awful floods which have filled some valleys with hundreds of feet of shingle and of sand, the process of re-occupation must have been very slow and tedious.

It is quite possible that in Southern England the vegetation had never been entirely destroyed, but in Scotland and Northern England it was only upon some black " nunatak" or projecting rocky mountain of high altitude that a few miserable alpines might have survived.

One has only to trace the course of the boulder-clay in order to see how utterly all vegetation worth the name must have been swept away. It was a new bare country which the first post-glacial plants set about occupying and developing. 


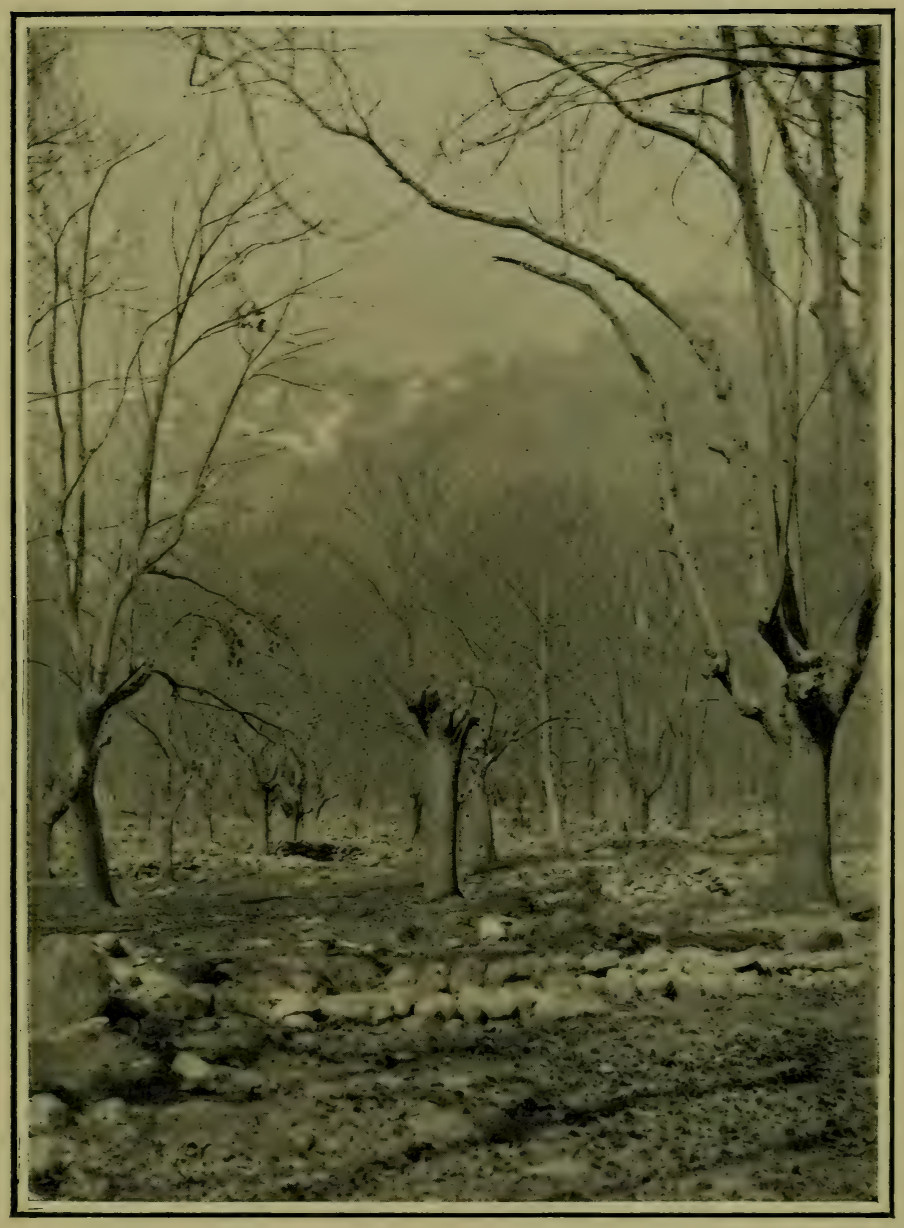

Author's Photograph

Chestnut Woods in a Corsican Valley

The climate may resemble that of preg'acial Europe. 



\section{The Origin of our British Flora}

Here were stretches of glacial boulder-clay, which is, as every gardener knows, one of the most heart-breaking and ungenerous of soils; there perhaps bare sand with only a colony or two of penguins (chiefly dead) to improve its aridity. In another place estuarine mud, where the sea-lions wallowed, or great stretches of gravel or shingle. On the hills, bare rock and screes of rough stones, in the valleys a multitude of wild water-courses carrying destruction and death to every living plant or animal during the autumn or spring floods.

There would surely be a heavy rainfall, long mournful weeks of cold saturating fogs; in winter a continual series of blinding blizzards; furious gales even in summer time, whilst in the higher hills there were still the shrunken remnants of former glaciers. It was of course impossible for such a country as this to be occupied straight off by our ordinary British plants, even if their seeds were at once available and in large quantities, which was not the case. The process must have been very slow and gradual ; lichens, mosses, and arcticalpines must have pioneered the way and only gradually extended from South to North, and from the seashore to the hill-tops.

In Northern Europe (at least in Norway, Sweden, Denmark, Schleswig-Holstein, North Germany, and Prussia) four invading floras have been distinguished which follow after each other, and appear to be still proceeding northwards on the track of the retreating glaciers. ${ }^{6}$

There are, first, the Dryas flora, which is a high arctic, or arctic-alpine, open flora such as now occurs in Northern Lapland; second, birch and aspen thickets; third, woods of Scotch pine, and fourth, oak forests.

As regards the Dryas flora, it consisted of, e.g., little dwarf willows (Salix polaris, S. herbacea, S. reticulata, 


\section{The Origin of our British Flora}

and S. arbuscula), of the dwarf birch, Arctostaphylos, Empetrum, and the blaeberries (Vaccinium myrtillus and V. uliginosa),* and may have resembled the usual arctic tundra (see p. 92). But there are several subarctic plants which ought to be added to this list, but which would not occur in those peat bogs from which evidence on these questions is usually obtained. Thus scurvy grass, Armeria, and Plantago maritima are both arctic plants, seashore plants, and also occur as alpines or sub-alpines in Scotland. It has sometimes been found difficult to understand why they should grow both along the sea and on rocky ledges at over 2000 feet. But the occupation of the land began on the seashore and gradually extended to the hills, so that the mountain scurvy grasses probably flourished at some time or other in all the intervening regions where they have been now choked out by other species.

Besides these, several estuarine and marsh plants, including some of the most important land-formers, can also endure an arctic climate. There are, e.g., Scirpus Tabernæmontani and S. lacustris, Phragmites, the two Triglochins, Menyanthes, Litorella, and others which seem to range into the subarctic, if not always to the true arctic regions.

So that even in the Dryas time there may have been quite a considerable occupation and colonisation of the river valleys and estuarine mud.

For the next or birch time, perhaps the North Cape of Norway or the Lofoden Islands might be the best example. It was still a very cold Britain with a July temperature of only $9^{\circ} \mathrm{C}$, and in August $7^{\circ}$ to $8^{\circ} \mathrm{C}$. Along with the birch were alder, hazel, and probably dwarf juniper. On the Continent Populus tremulus, the aspen poplar, seems to have been characteristic. With 


\section{The Origin of our British Flora}

these one would expect the blaeberries and very likely heather and heath.

The Scotch pine-forests seem to have soon followed on and dispossessed the thickets of birch and alder. This was, of course, an infinitely more advanced type of vegetation, for many common British plants seem to have accompanied the pines. Mr. R. Smith gives Ranunculus acris, Eyebright, Pyrola, Scabiosa succisa, Galium saxatile, Holcus lanata, Festuca ovina, and one or two ferns.

But the climate was still cold and unpleasant with a June temp. of $9^{\circ} \mathrm{C}$., July $12^{\circ}$, August $10^{\circ} \mathrm{C}$., which is about that of the Orkney and Shetland Islands.

The time of pine-forests must have lasted at least for thousands of years.

The last invasion by the oak-forests has not succeeded in occupying the greater part of Scotland and Wales, for the old English oak-forests, Jed and Dalton forests in Scotland, as well as others, seem to be chiefly in the lowlands. The pines covered many of the hills and also much of the lowlands, where the soil happened to be bad and poor.

The levels to which oak, pine, and birch have been traced are difficult to determine exactly, but some information can be found in the Botanical Survey maps (see p. 224).

Unfortunately birch occurs in both pine and oak woods. Nor is it easy to be sure of the natural presentday limit of any of these trees. But such a succession as this is quite natural and understandable; one can see it on mountain sides or in Northern Europe as one travels north from the temperate to the arctic zone. Moreover, it is the more advanced type, such as the oak, which follows on and dispossesses the simpler association of pine-woods. On good soil, oaks will anywhere choke out pine-trees, ${ }^{7}$ just as pines will eventually over- 


\section{The Origin of our British Flora}

top and smother any young birches that are growing amongst them.*

So that this gradual succession of these four associations seems very plausible, and would give a clear picture of the conquest of Britain by the plant world.

The upper limit of the oak lies between $75^{\circ}$ feet and I 250 feet, that of the Scotch fir between I $25^{\circ}$ feet and 2400 feet; whilst the birch goes distinctly higher than the pine, and reaches 2700 feet in the Eden, Wear, and Tyne district.

But as every one knows who has been in the Highlands or on the Yorkshire moors, we do not find to-day any such distribution of pines and oaks as one would expect from the preceding data.

Between the scanty alpine or subalpine flora of the mountain tops or hill summits and the plantations in the valleys, there are almost always enormous areas of desolate, whaup-haunted moorlands or cotton-grass or stretches of peat-bog. Sometimes grass pastures, fit only for blackfaced sheep or cheviots, are scattered amongst these desolate and uninhabited haggs and mosses, but this is not often the case in Scotland.

The late Dr. Robert Smith initiated a very valuable work, which has been continued since his untimely death by his brother, Professor W. G. Smith, and Messrs. Lewis, Rankin, Peall, Moss, and others. This is the Botanical Survey which has been already carried out for Forfar and Fife, Perthshire (North), Edinburghshire, Yorkshire, the Eden, Wear, and Tyne valleys, and part of the Pennines. ${ }^{8}$

On these survey maps the particular vegetation is marked by special colours. One can detect at once

* At Lake Hielmar in Sweden, birch, aspen, alder, and willow first established themselves on the islands formed by the lowering of the water. Then Scotch fir and spruce occupied the islands, replacing the birch association. ${ }^{7}$ 


\section{The Origin of our British Flora}

the heather moors, grass-heath, or cotton-grass, which are sharply marked out from the cultivated land or permanent pasture.

One can also see the relative value of the land, what part of it is promising for plantation, and the amount of peat-moss or other really useless country. But unfortunately this is a matter which requires skilled botanists and money, so that at present but a very small part of Britain has been botanically surveyed.

However, the main point which these survey maps bring out very clearly is the fact that pine forest does not occupy the interval between the summit floras and cultivation.

But besides this present-day survey, there are the researches of Mr. Clement Reid and Dr. Lewis, who have studied the Scotch peats and other glacial and pre-glacial beds. From these we find indisputable evidence of the Scotch pine forest which we would have expected.

On the desolate Merrick hills in the southern Scotch uplands, and at 800 to 1000 feet altitude, Dr. Lewis found the remains of a forest of well-grown Scotch pines 18 inches to 2 feet in diameter where to-day there is scarcely a shrub 3 feet high.

On Tweedsmuir and the Moorfoots similar birch or pine forests were discovered buried in the peat and whose existence was quite unsuspected.

Dr. Lewis found similar relics in various places in the Highlands. In fact his researches make it certain that there was once a splendid forest of Scotch pine covering those parts of Scotland where we would have expected them, if this succession of dryas, birch, and pine really existed. ${ }^{9}$

In the peat-mosses and flows at lower altitudes there is, or used to be, plenty of oak logs, which show that 


\section{The Origin of our British Flora}

the oak had also succeeded in invading Scotland. But this is just the point where the difficulties begin, for it is known that when the ice began to vanish away from our islands there was no regular steady improvement of climate, but many fluctuations and changes which are not yet understood.

Even in Sweden it has been shown that the hazel once occupied many districts from which it is now absent. To-day it only occupies two-thirds of the country which it had conquered during the time that followed the first great shrinking of the glaciers. Gunnar Andersson supposes that Sweden of to-day is distinctly colder (about $2.4^{\circ} \mathrm{C}$. less in mean annual temperature) than in the flourishing period of the hazel. ${ }^{10}$ These changes of temperature belong to a very intricate series of geological questions upon which the writer is not competent to give an opinion.

It is generally allowed by all continental botanists that after the first and greatest of the Ice Ages, a long period of time ensued during which the climate was hotter and drier than it is to-day. Then followed a distinct relapse into a Little Ice Age, which was by no means so severe as the Great one, but yet cold and wet enough to leave very distinct traces.* This relapse is accurately shown in Dr. Lewis's sections of peat-mosses. A layer of arctic plants occurs between an upper and a lower forest. So in the Merrick hills, at about 800 feet, a distinct layer of Empetrum is found. This plant does not now grow in this district below at least 1500 feet. The climate was therefore distinctly worse than it is

* Mr. Lamplugh, in a polemical address to the British Association, denied the existence of any of the climate changes worked out in detail by Professor James Geikie. But even in this very paper he admits changes of some sort, and every continental geologist seems to agree to one if not more warm interglacial periods. 


\section{The Origin of our British Flora}

to-day, and worse than it was in the same district at an earlier date, when birches grew in the same place. Such peat-mosses show a succession of deposits as follows :-

Recent or Youngest 7. Peatmoss, Sphagnum.

6. Pine forest or Upper Forest.

5. Peat bog plants or Upper Peat bog.

4. Arctic plants or 2 nd Arctic, Empetrum.

3. Peat bog plants or Lower Peat.

2. "Birch or Lower Forest.

Oldest Deposit I. Ist Arctic or Dryas flora. ${ }^{9}$

From Mr. Clement Reid's papers, and especially his "Origins of the British Flora," we know not only a large number of the plants which were found in Britain during the Ice Age, but also a large number of preglacial plants.

Even at that distant date, chickweed, Polygonum persicaria, meadow-sweet and hawthorn were living in England. The alder and bogbean (Menyanthes) were not only preglacial but occurred in all the deposits down to those of Neolithic age. There are many signs of the warmer and milder character of the interglacial period which, as we have seen, is indicated even in Scotland. Trapa natans is now no longer British, though it grew near Cromer before the Ice Age. Indeed, what strikes one most from these lists is how little and not how much difference was caused by the great ice invasions.

It is a very pleasant duty to recognise the extremely valuable nature of these discoveries, which have indeed explained the past history of the British flora in a very satisfactory way. The British botany of to-day may indeed be proud of these researches, though there are of course many doubtful points as yet unexplained.

Dr. Lewis has compared his results with Professor 


\section{The Origin of our British Flora}

Geikie's arrangement of the various Ice Ages. These are as follows for Scotland :-

Most recent Upper Peat-bog or 6th Ice Stage.

Glaciers in Highland corries. Snowline at 3500 feet.

Peat above Upper Forest : raised beaches at 25 to 30 feet.

Somewhat cold and wet climate.

Upper Forest or 5 th Interglacial Stage.

Upper Forest. Climate reiatively dry and genial.

Land area somewhat greater than to-day.

Lower Peat-bog or $5^{\text {th }}$ Glacial Stage.

Glaciers in Scottish valleys. Average snowline 2400 to 2500 feet. Raised beaches at 45 to 50 feet.

Cold and wet climate. Lower peat deposit. Lower Forest or $4_{\text {th Interglacial Stage. }}$

Genial climate with a greater land area than exists to-day.

Lower forests or morainic accumulations of 4 th Ice Age. Oldest or 4 th Ice Age (Mecklenburgian).

Large glaciers in Scottish Upland and Highland valleys.

District Ice sheets. Raised beaches at 100 to I 35 feet. Arctic climate with the permanent snow at rooo feet in west and north-west, to 1500 or thereabouts in central Scotland.

But there is a difficulty with regard to the latest of these deposits. Above the lower forest there is from 4 to 9 feet of peat, chiefly composed of sphagnum moss. How many years are required to form this thickness of peat? Unfortunately the rate at which peat accumulates is so variable that no definite answer can be given to this question, but nine hundred years would surely be enough for this accumulation, which would bring us to about I000 A.D.

Now in Scotland there is strong evidence for the existence of great forests which existed, at any rate, at that date, and continued over much of the country until at least the period of the Border wars. The great oak 228 


\section{The Origin of our British Flora}

forests of Jed and of Dalton covered huge areas in the south. When Robert the Bruce narrowly escaped from his pursuers in Glen Trool, the impression which one gets from the contemporary accounts is that the country was covered with trees, probably of pine.

At a much earlier date one finds frequent references in Tacitus and other Roman writers to the Silva Caledonica of, apparently, great pine trees.

Tacitus himself is much too flowing and literary in his appreciation of the great Agricola for much trust to be placed in his allusions, but the plain deduction from his and other Roman authors seems to be that Scotland was then a forest-clad, marshy, feverish country, which, in their view, would never be of the least importance to civilised man.

The population seems to have been large, for it is the fact that the Picts and Caledonians invaded England before I 20 A.D., about I 38 A.D., in I6 I A.D., on the accession of Commodus, before 208 A.D., when Severus lost 50,000 men in Scotland, and frequently after that. Moreover, there was a large population in Scotland long before any Roman saw the country. There were great Neolithic settlements which should surely have commenced at least rooo B.c.

So far as one could draw any conclusion from these facts, the upper pine forest of the deposits is just the Silva Caledonica of the Romans and the traditional Scotch forest which was of pine in the uplands and of oak in the lowlands.

Its destruction could be satisfactorily explained simply by the continual cutting and burning necessary to support a large population, and especially by the ravages of goats, black cattle, and horses, which would prevent any reafforestation.

So the Romans and Scotch savages would seem to 


\section{The Origin of our British Flora}

have been living in the sixth glacial stage, and to have known nothing whatever about it!

But unfortunately for this explanation, the land is supposed to have been 25 to 30 feet lower during the sixth glacial stage, and if this is the case the Roman wall should show that it was not intended to reach as far as the modern sea-beach, but only to about 25 or 30 feet above that level. Here, then, is a little antiquarian point which turns out to be of great scientific importance!

Otherwise it is very difficult to understand why the traditional Scotch forest has utterly vanished and left no trace whatever in the uppermost or recent peat. But there has not been yet, by any means, sufficiently extensive researches to be sure if this is the case or not.

On the Continent there are some authors who have traced the effect on the plant world of quite similar fluctuations of climate in the later stages of the Ice Age. What corresponds to Geikie's sixth Ice Age is, for instance, earnestly required by Schulz.

The North German heath, a "mantle of coarse sackcloth with a border of silk," which occupies an enormous area of North Germany, is supposed by Graebner to have been once a Scotch pine forest. He, however, does not think apparently that it was destroyed by man, but by some climatic change or the impoverishment of the soil. ${ }^{11}$

But in Switzerland and central Germany it is supposed that the destruction of the forests by mankind took place between 400 A.D. and I 200 A.D., which is just the period during which our Scotch traditional forests were destroyed. The reader will see how much has yet to be discovered before it is possible to bring tradition and antiquarian discoveries into line with modern geological and botanical research.

But leaving these interesting little details, it is clear that, as regards our general British flora, it may be con- 


\section{The Origin of our British Flora}

sidered as consisting mainly of the four great invading armies of plants.

In the North, in some parts of West Ireland, and upon the Scotch, Welsh, and a few English mountains, we still find Dryas and its little willows, and other characteristic arctic or alpine plants.

The birch association is but seldom represented, but shrubs of birch, rowan, larger willows and junipers, occur on steep corrie sides and other places where they cannot be destroyed by sheep.

Lower down most of the heather moorland, diversified by the silvery sheen of the cotton-grass, peaty mosses, or rushy grass pastures, represent the old Scotch pine forests.

In the fertile, low-lying parts of Scotland, oak forest used to cover most of the country, but it is now replaced by arable land or permanent pasture. The valley floors or flat river holms seem, as we have shown elsewhere, to be due to the reeds (Phragmites and others), which choked unnecessary water channels and intercepted the river silt.

Besides these main groups, which form a very large proportion of the Scotch flora, there are several other and distinct divisions. The number of weeds is very great but can never be accurately estimated, for with changes of cultivation some die out and strangers enter in. All over Britain one finds the Canadian weed Elodea, which seems to have first been noticed about r 843. The Chilian Mimulus has got a firm footing by the southern Scottish rivers and burns, and occurs abundantly even in the marshes of the Tay. Claytonia siberica is establishing itself in the West of Scotland, and seems to be extending its range annually.

Many other interesting cases will be found in almost any county flora, or in the pages of the Journal of Botany, and which show that the flora of Britain is 


\section{The Origin of our British Flora}

always slightly changing. There are also, of course, the usual weeds of worldwide distribution, such as the common nettle, Luzula campestris, common avens, bracken, and black maidenhair spleenwort. Of these there are said to be no less than 182 species. ${ }^{12}$

But there are two other difficult questions which ought perhaps to be mentioned.

In Scandinavia an invasion of the beech followed after and dispossessed the oak. In some German maps the beech is shown as dominating practically the whole of northern and middle England. That, however, does not seem to have been proved, for no evidence can be drawn from our modern woodlands, which are all more or less artificial, and the ancient English forest seems to have been oak or beech. Yet the tree is supposed to be a native. Gerard, in I597, says: "Fagus ... in many forrests and desart places . . . in Kent." It is particularly common now on chalk and limestone.

Yet one can hardly believe that a beech forest in prehistoric or early historic times ever entered England and displaced the British oak.

The steppes at one period in glacial times entered Europe and extended certainly into France and Switzerland.

In the east of England there are several counties which possess a far drier and sunnier climate than is usual in Britain; but, so far at least as the author is aware, the characteristic steppe plants have either never reached England at all, or failed to hold their own if they did manage to enter during the first interglacial epoch.

But there is a whole series of very interesting plants which may really be relicts of that very distant time. The best known of them are the arbutus, and the Cornish and Mediterranean heaths. One might also mention the wild asparagus, Simethis, Romulea, Poly- 


\section{The Origin of our British Flora}

carpon, Allium triquetrum, and perhaps the wild gladiolus, but it is very difficult to give a satisfactory list. These belong to the west and south of France, Portugal, and Spain, and might be supposed to represent an outlying part of the Mediterranean flora.

They occur along the south coast of England, in Ireland, and in some few cases also in the south-west of Wales, which seems at first sight to be a very inexplicable sort of distribution.

But if one takes Bartholomew's Physical Atlas (Plate I8), which gives the distribution of sunshine in the British Isles (after Mr. H. N. Dixon), a very interesting coincidence can be traced. The sunniest part of Britain, which possesses from 1600 to 1700 hours of sunshine in the year, includes very nearly all the habitats of these rare Spanish plants. The line of 1600 hours of sunshine cuts off Beachy Head, part of Dorset, about two-thirds of the Isle of Wight, and a considerable portion of south-west Cornwall and Devonshire ; it then curves up to the north so as to take in a little of southwest Wales, and fringes the southern Irish coastline. The Irish observations seem to have been insufficient, but it seems that the curious sporadic and irregular distribution of these peculiar southerners really does more or less coincide with a sunshine amount of between I 600 and 1700 hours per year.

This part of England seems to have escaped the ice of the glacial period, and it is quite likely that the arbutus and asparagus are relicts of the first warm and dry interglacial period. But of course this is a question which requires much more detailed evidence.

There is yet another little group, the Blue-eyed grass, Eriocaulon, and Spiranthes Romanzofiana, about which there has been plenty of speculation and discussion. The last grows in Kamschatka, and also in Bantry Bay, 


\section{The Origin of our British Flora}

Co. Cork. The blue-eyed grass (Sisyrhinchium) is found in Galway and Kerry, and Eriocaulon in Skye and West Ireland, but both of them are typical North American species. There are two possible explanations of their presence in Ireland. They may be relicts of that very ancient Tertiary flora, which seems to have entered Europe by way of Greenland and Scandinavia, and which have succeeded in living through all the Ice Ages in these particular spots.* Or they may have crossed the Atlantic perhaps within quite recent times. Drifted timber from America occasionally reaches our western shores, and it is by no means impossible that seeds of Eriocaulon could have been transferred in the crevices of a floating log. It is said that the seeds of Mucuna or Entada, which float over to the Hebrides from America, are sometimes able to germinate. It seems, however, more probable that the Sisyrhinchium has to thank some wandering migrant bird for its introduction to Ireland ; its small hard seeds would appear to be well adapted to this form of transport. $\dagger$

This short sketch of a very interesting subject will at any rate show that there is still a very great deal to discover before we can understand the origin of our British flora. Before the Ice Age, and even before the intricate changes of climate which characterised Tertiary Europe, several of our common British genera must have existed somewhere.

The chase of "a panting syllable through time and space" is not nearly so fascinating as the story of a living plant. One of the most successful hunts of this kind is that for the original home of the cinnamons. These were found as fossils in the oldest chalk deposits

* This is the explanation given by Hartz, who found another American plant (Dulichium) in three interglacial peat deposits in Denmark.

+ Compare Guppy, l.c. 


\section{The Origin of our British Flora}

of Greenland and North America. They did not reach Europe until the Eocene, but appear to have afterwards enjoyed a European life, for in the Miocene they are important trees from the Baltic to the Mediterranean, and from the Atlantic to the Black Sea. They were driven south in the Pliocene age, and have now retreated to the shores of the Pacific and Indian Oceans, where they still live in some districts that have from 50 to 80 inches of annual rainfall. Their western boundary now is the dry climate of the Persian and Arabian desert, and to the north the Himalayas and other great mountainranges. ${ }^{13}$

This is rather a triumph for the botany of to-day. The cinnamon has been traced from Ceylon to Greenland and during the whole interval of time that has elapsed from the first Cretaceous deposits to our own days!

1 Laurent.

5 Schulz.
4 Willkomm.

7 Dengler, Birger.

8 Smith, R. and W. G., Lewis, Smith and Lewis, Smith and Rankin, Moss.

9 Lewis. $\quad 10$ Andersson. 11 Graebner. ${ }^{12}$ Hoek. ${ }^{13}$ Stant. 


\section{CHAPTER XXI}

\section{CONIFERS}

THE coldest place in the world is said to be a certain settlement in Siberia called Werchojansk. It is not so very far north $\left(67^{\circ} 34^{\prime} \mathrm{N}\right.$. lat.), but yet the cold is almost impossible to realise. During the three winter months the thermometer is never above $-24.3^{\circ} \mathrm{C}$. and occasionally sinks to $-64^{\circ} \mathrm{C}$. Indeed it is only in the four months, June to September, that the mean temperature is above the freezing point. July is the hottest month, but the highest temperature recorded is only $29^{\circ}$ to $30^{\circ} \mathrm{C} .^{1}$

Now Werchojansk is in the Siberian forest region, so that trees do manage to exist even in this climate.

It can hardly be expected that when they have only some two months in which to grow, the results will be at all remarkable. A tree of Pinns cembra about 6 feet in height, for instance, will probably be seventy years old, but the fact that they can grow at all in such places as Werchojansk seems to prove that it is not mere frost and snow that hinders the northward extension of the forest.

All round the North Pole, though at a very respectful distance from it, there seems to be a belt of coniferous forest. No doubt thickets of birch go even farther north than the conifers; but pines, spruce, or larch form the great northern woodlands, and the deciduous oaks and beeches are only found in much more southerly latitudes.

It is not the cold but the drought which prevents these conifers from growing much farther north than 


\section{Conifers}

they now extend, for Werchojansk is much colder than many places beyond the range of conifers. This seems remarkable when these pines inhabit a country which is buried in deep snow for months together, but it is nevertheless true that pine needles die of drought even when the ground is everywhere snow-covered.

Suppose under these conditions that the sun shines out and an icy wind begins to blow, then the snow rapidly melts and the leaves at once begin to try and form sugar. But where is the water to come from? The roots are buried in ground frozen solid for several feet downwards, and even the sap in the stem is nothing but ice. So it often happens that the needles wither, turn brown, and drop off. This happens even to our own hardy Scotch pine when there is a day or two of brilliant sunshine during a very hard frost.

It is this danger also that explains some of the most remarkable peculiarities of pine needles. The bluegreen, waxy appearance, the solid fleshy sort of structure, and the way in which the breathing pores are sunk below the surface, are all at once understood by remembering this danger of drought.

In other respects conifers show that they are well fitted to resist both cold and snow. They store up their winter reserve-stores in the form of fat or oil, not as starch. ${ }^{2}$ This has been compared to the fattening up of bears and other hibernating animals, and it is at any rate true that the vegetable fatty and oily substances are better fitted to resist the effect of hard frost. The resinous character of most coniferous trees is also of great importance, for wounds caused by a broken branch, or some insect which burrows into the wood, are effectively sealed up. Conifers always possess a root-fungus or Mycorhiza, so that they are able, like heather, \&c., to use peaty soil in which ordinary plants do not thrive. As we have already seen elsewhere, they follow on after 


\section{Conifers}

birch thickets and alpine plants, and their special absorbing Mycorhiza is no doubt well fitted to find the necessary salts as rapidly as possible. Under the microscope the appearance of some pine roots is very remarkable, for they are entirely covered over by a sort of webbing or felt of fungus threads.

The distribution of conifer forests in the world is particularly interesting. They begin in the north as a complete ring surrounding the Pole, but at different degrees of latitude. These northern woods are not, however, the same. Our Scotch pine goes farthest north in Scandinavia, but not in Russian Siberia, where it is replaced by the fir, which seems to be able to grow better on swampy, peaty ground. Beyond the Urals, the Siberian larch is the most northerly tree, and sometimes goes as far north as $72^{\circ} 40^{\prime} \mathrm{N}$. lat. ${ }^{3}$

Pinus cembra replaces the larch from the longitude of Werchojansk to Behring Straits. In America, spruce, Picea sitchensis, and Pinus contorta and Murrayana are the most northern trees in Alaska, but east of the Rockies it is the American larch that is the pioneer of woodlands. Greenland has not any trees in the present geological epoch.

These differences are very curious and have not been explained, but it is possible that the larches can best withstand the continental conditions, where there is less rainfall, than the pines and spruces. The pine seems to prefer drier and rocky ground, and the spruce does better on sodden peat and in swamps.

The "forest primæval" of these far northern latitudes is not at all impressive. The trees are scraggy, stumpy, badly grown and covered with old man's beard and other lichens.

From these northern forests there are in each continent diverging woodlands, which take to the mountains when they arrive at more genial latitudes. For, as we 238 


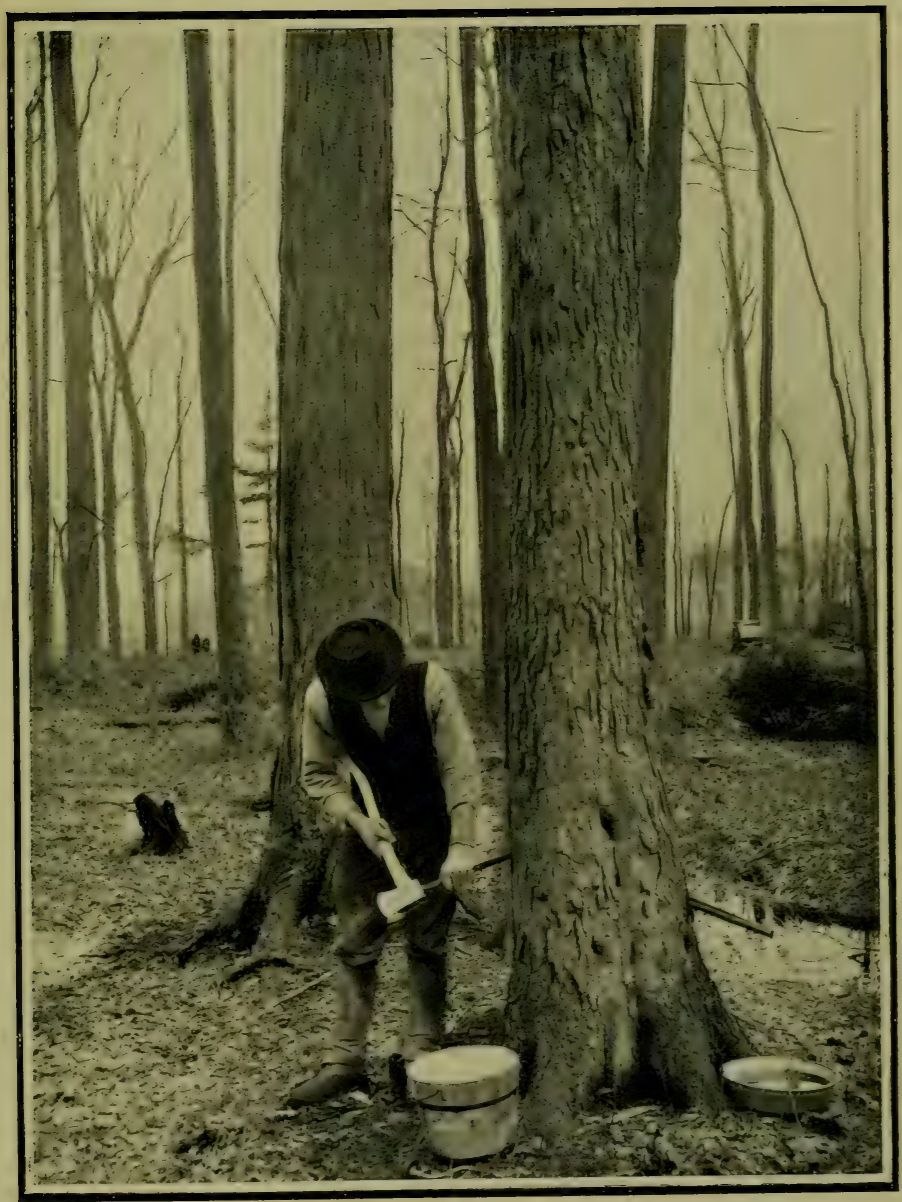

International]

[Publications Co

Tapping a Maple Tree for Sugar

This is a regular industry in Canada. 



\section{Conifers}

have already mentioned, oaks and other decicluous trees kill out the pines in good and fertile valleys.

They do, however, manage to hold their own on poor and peaty land. Thus in the Hartz Mountains, the Scotch pine still grows on chalk or poor granitic soil, whilst the richer Silurian and Carboniferous rocks have been won from it by the beech. ${ }^{4}$ Sandy stretches along the seashore are often pine barrens, as, for instance, along the Atlantic seaboard of the United States.

These peculiarities in distribution are quite simple if it is correct to suppose that the pine is a sort of forerunner or pioneer for the more advanced cleciduous woodlands.

In the Alps, and on all north temperate highlands, there is almost always a mountain forest of conifers. Our common Scotch pine ascends to 2743 metres (9000 feet) on the Caucasus, and its variety, montana, reaches at least 2695 metres ( 8850 feet) in Europe. Farther south one finds the Cedars of Lebanon and of Mount Atlas, and far away down in British Central Africa there is another conifer forest on Mount Mlanji, where Widdringtonia Whytei forms exceedingly fine trees at altitudes of 10,000 feet. It is, of course, unnecessary to mention all these coniferous forests, but the Deodar association on the Himalayas, and especially the beautiful woods of British Columbia, ought to be described.

Those of British Columbia are full of magnificent giants, such as the Douglas fir, which is often 200 feet high (Io to I 2 feet in diameter). Nor is this the only giant amongst them, as the following short list clearly shows :-

Sitka Cypress (Chamæcyparis nootkatensis), often 120 feet high, 5 to 6 feet diameter.

Sitka Spruce ( 100 to 200 feet high), I 5 to 16 feet diameter.

Red Cedar (Thuja plicata), often 200 feet high, 15 feet diameter. Mountain Hemlock (Tsuga Mertensiana), 70 to 150 feet high, 4 to 5 feet diameter. ${ }^{5}$ 


\section{Conifers}

In British Columbia these huge trees grow within a few feet of one another on a soil which is only a few inches deep, and generally only porous gravel of glacial origin. The climate is cool, with a long vegetation period and a rainfall of about 70 inches. There is much in what one hears of the forests in British Columbia which tends to make planters in Scotland exceedingly envious.

The only one of these trees which has been tried in this country on a considerable scale is the Douglas fir, and this has been a great success.

Larch has been hitherto the main stand-by of British forestry, but doubts are now being expressed as to whether after all this is the best tree for our insular climate.

Buhler and Kirchner consider that the larch requires plenty of sunshine. In Europe it only grows naturally on a rather narrow strip of country which runs from Dauphine (France) by the Vorarlberg and Salzburg Alps to the Highlands of Poland, where it bends south towards the Carpathians. Throughout this natural larch country there is at least I 750 hours of sunshine in the year.

No part of Britain is so fortunate in its sunshine as to possess more than I 700 hours, and where larch is grown on a large scale, as in the Highlands and Western Scotland, there is probably only 1400 hours of sun, or far less than this amount.

On the other hand, the climate of British Columbia seems to be very like that of the Highlands of Scotland and part of Wales and Cumberland.

Still the well-known and valuable larch often does extremely well on sunny steep-sided slopes even in this country, and if this is so no one would suggest trying any other tree instead of it.

It is now thought that the ravages of the larch disease 


\section{Conifers}

(Peziza Willkommii) must be considered to show that the ground or the conditions are unsuitable for the trees.

Want of light, stagnant humid air, soil which is too wet, too dry, or too poor, or even the attack of insects, bring about a depressed state of health. Larches in this condition will succumb or be injured for life by this dreaded fungus. The spores of it are carried by the wind, and may reach wounds which are 60 feet above the earth ${ }^{6}$

But farther south, in America, there is a strangely isolated group of one of the oldest living conifers. On the western slopes of the Sierra Nevada in California, at heights of 5000 to 8000 feet, the big trees of Sequoia (or Wellingtonia) gigantea still manage to exist in spite of the demands of millionaires who wish to make diningroom tables of one cross-section of their trunks. As they already form the centre of a thriving tourist-industry, they are quite sufficiently advertised already, and it is unnecessary to say much about these survivals. They reach sometimes 320 feet in height, and may have a diameter of 20 feet. Some are said to have been 3300 years old. When grown as specimens in British woodlands they are not particularly beautiful, and they are not found to be of much importance in economic forestry.

In South Chile and in Southern Brazil, in the district of San Francisco $\left(15^{\circ}-30^{\circ} \mathrm{S}\right.$. 1at.), there are still left a few small forests of the monkey puzzle (Araucaria imbricata). They seem to have been surrounded and hemmed in by woods of a far more modern and efficient type. Indeed they are apparently dying out everywhere.

This is perhaps the oldest type of tree in the world, as is at once impressed upon one's mind. The branches, thickly covered by prickly leaves, makes one wonder as to what extinct animal had to be prevented from browsing on their foliage. But that is not all, for 


\section{Conifers}

everything about them gives an archaic or, shall we say, a "Jurassic" look. The stiff, clumsy branching, the solid, thick, and knobby stem, with a swollen bulging at the base, is altogether unlike anything that we are accustomed to. Their large seeds used to be the main support of some of those fierce Indian tribes in Southern Chile who were never conquered by the Spaniards even after $25^{\circ}$ years of continual warfare. They are more ancient even than those other fine conifers which occur in the forests of the Andes farther to the south, such as Fitzroya, Libocedrus, and Saxegothea, all of which belong to an ancient group of conifers.

In the extreme south of South America they are perhaps being crowded out by the antarctic beech, which is more hardy and perhaps better fitted for the terrible storms and icy blizzards of that savage and even to-day almost unexplored territory.

The way in which these archaic coniferous genera, and especially Araucaria, appear in the most unexpected places all about the Pacific, is perhaps best explained by supposing that they really are the last isolated remnants of the most ancient tree type in the world, which have just managed to survive in odd and out of the way islands and mountain woods (see p. 282).

The general distribution of the more modern pines, spruces, and larches quite agrees, however, with the theory that they are preliminary associations, able to exist on poor land, in high mountains and the frozen north, but unable to compete with deciduous trees where the soil and climate is good and kindly.

The appearance of a "forest primæval" differs of course in different latitudes. In the more northerly latitudes one is apt to be bitterly disappointed. The trees are scraggy, stumpy, badly grown, and loaded with old man's beard and other lichens. In more genial 


\section{Conifers}

climates it is exceedingly difficult to find any natural pine forest. If only a few more proprietors had followed the noble example set by Prince Ad. von Schwarzenburg, who left a will ordering that " 3200 yoke should be preserved for ever," so that the original Forest of Bohemia could be understood by succeeding generations! The forest which we owe to his selfdenying ordinance consists of firs, silver firs, and beeches, as well as of sycamore, elm, alder, birches, and willows. Here may be the huge mouldering trunks of dead giants, from whose prostrate stems spring rows of little shoots, patiently waiting for a chance to clevelop. The soil is everywhere covered over with green feathery mosses, in which are growing hundreds of little suppressed youngsters (some perhaps I 20 to I 60 years old, though not more than 7 inches in diameter). When some venerable patriarch does eventually fall, then these small ones get their chance and quickly grow up towards the light, for which they have been so long patiently waiting.

In those Highland woods which have been in existence for at least a century, one can realise up to a certain point the extraordinary charm of a natural forest. The great trees are covered with rare and curious lichens. The ground is broken, rocky, and uneven, but over it all, over boulders and dead trunks, there is thrown a most wonderful tapestry of feathery mosses, with here and there blaeberries, Trientalis, Veronica officinalis, dwarf cornel, brambles, and bracken, with splendid male ferns and lady ferns. The bewildering variety of this ground flora clearly depends upon the amount of light which penetrates through the branches.

But the influences at work are of the most complicated character. The trees are all competing for light ; should a leading shoot be broken as by a playful 


\section{Conifers}

squirrel, then the next side shoot grows upwards and becomes a leader. Yet in a general way there are distinct differences both in growth and in behaviour to light of the main horizontal branches, and of those of the third and fourth order which spring from them.

In some conifers (Cupressinex), if one makes a cutting from one of these side-shoots, it may grow into a tree, but always preserves its side-shoot character, never growing properly like cuttings from a leading shoot. ${ }^{7}$ The amount of light required by the different trees, shrubs, and herbs differs enormously.

Box can grow even in shade so deep that only one-hundredth part of the daylight reaches it. Young beech trees will form abundant leaves even in only onefourth of the natural daylight. ${ }^{8}$

Similar differences are found in the behaviour of the herbs and other ground vegetation. When, $e . g$., a great tree falls and light reaches the wood-floor, numbers of seeds, which had lain for years in the leaf mould, suddenly germinate. Other roots and rhizomes which had gone on stolidly living and forming perhaps a very few leaves every year, or tying up the ground by long branching runners without ever flowering at all, these, as soon as the genial sunshine touches them, awake to full activity and grow and flower luxuriantly.

A very few, such as Dentaria bulbifera, prefer the dark shade and moist humus of the closer parts of the forest.

Supposing, however, that such a clearing is planted with young conifers, they have at first a struggle against the nettles 5 or 6 feet high, perhaps 6 feet of bracken or quick springing brooms, birches, and whins; but so soon as their branches begin to touch one another, the undergrowth begins to vanish away. No seeds germinate, and the perennials return to subterranean runners and roots.

The branches of the treesthen begin to compete among 


\section{Conifers}

themselves. The older, lower branches continue at first to form a few green leaves at their tips ; but there comes a time when such leaves get no light. In that case they die and drop off early in the season. Such a branch, having no water-transpiring leaves at its end, begins to die at first gradually, but it soon dries up altogether and becomes absolutely dead and useless; generally it is powdered all over by the green dust of the Alga Pleurococcus. Whilst on the tree such dead branches are not usually attacked by fungi at all.

If, on the other hand, a branch with living leaves is cut or lopped off, the fungi attack it promptly and may make their way down it and infest the trunk itself.

But as the tree grows and its trunk expands, the dead branches drop off and fall into the mass of dead needles and leaf mould. There they are soon investigated by burrowing beetles and miscellaneous insects. The threads of the rich fungus flora in old woods find them out, and they are broken up and absorbed by Hydnums, Russulas, Agarics, bacteria, and the like.

They are soon turned into humus and may again become food for their parent trees.

One of the most alarming trade-prospects in the world to-day is the rapid exhaustion of conifer forests. Year by year shows an increasing area of farmland and arable cultivation. The forest is rapidly disappearing everywhere, being used up to form pulp for the world's newspapers, for railway sleepers, and the numberless trades which depend upon deal and other wood products.

We in Britain are infinitely worse off even than most continental countries, for the amount of English soil under trees is only 5.3 per cent., of Scotch 4.6 per cent. (Wales 3.9, Ireland I.5) of the total area.

The forests of Germany cover 25.9 per cent. of the country (Austria 32.6, Belgium I 7.3 per cent.). 


\section{Conifers}

This is not because we do not use wood. On the contrary, we import not only wood to the value of

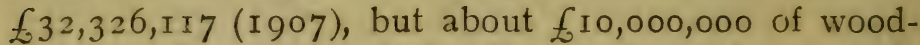
pulp or of paper made for the most part from woodpulp.

Nor is it because the land is in any way unsuitable for timber. The Royal Commission which has recently sat upon this question estimates that there is 9,000,000 acres of quite suitable land, chiefly "rough mountainland used for grazing." This estimate is probably far below the real area, but unfortunately all estimates are at present just guesses. If the Botanical Survey of Britain had been carried through, it would have been possible to state exactly the precise area of possible forest land.

Dry heather moor, when not above a certain altitude, is generally well adapted to conifers, and there are many stony and barren-looking hills which are able also to grow good trees. But such plantations must not be above a certain altitude, which varies in different districts according to the heights of the highest hills in the neighbourhood.

Does forestry then not pay in this country? The best British authorities have shown that land producing only 5s. per acre as grazing ground for sheep can be made to return Ios. per acre when planted. Then one begins to wonder why it is that there are so few plantations, and why private enterprise has not grown again the great Silva Caledonica of ancient times.

The answer is, however, perfectly simple and adequate. Forestry as usually conducted is most uncertain. It cannot unhappily be denied that the scientific side of it has been grossly neglected in Britain, and too often dangerous errors and wrong practice have led to ruinous losses.

But let the reader suppose himself to be twenty-one years of age and to have succeeded in 1909 to a large 


\section{Conifers}

estate with many acres of "rough mountain pasture." After he has paid succession-duty and other very heavy expenses, will he start planting several thousand acres? There will be a huge profit in 1979 or 1989 , but will he live till he is ninety-one years old and be able to enjoy it? Moreover, if he marries and dies, say, at sixty, that is, in 1948 , his son will have to pay a far heavier succession duty because of his father's plantations, and will not get his money back till forty years afterwards!

But that same land is always bringing in a small but sure and safe return as sheep pasture or possibly as a grouse moor. In order to plant it with conifers, all this profit must be lost. When one reflects upon these obvious facts, the wonder is not that so little planting is done, but that any proprietors at all should be publicspirited enough to start new plantations!

The recommendations of the Commission are magnificent, and if carried out would produce a clear profit of some $f_{107,000,000}$ at the end of eighty years (that is, allowing compound interest on the money invested). But to obtain this profit, the State must buy outright $9,000,000$ acres and spend $f_{\mathcal{L}}+50,000,000$ sterling. (An annual outlay of $£_{2}, 000,000$, and deficits which will rise to about $£ 3, \mathrm{I} 3 \mathrm{I}, 250$ in the fortieth year, account for this substantial sum.) One can only hope that any Government will be found bold enough to undertake a scheme of this gigantic nature. Unfortunately the experience of Government undertakings in this country does not lead us to expect economy in management.

Quite apart from the money question is the fact that, on such land, one shepherd and a gamekeeper are employed on some rooo acres. Under trees, on the other hand, at least ten foresters and two gamekeepers would be necessary. So that a very large number of countrymen of the best class would find employment in these State forests.

But surely some method could be devised of subsi- 


\section{Conifers}

dising proprietors, and taking care that really qualified experts are always available to advise and give counsel, and of course taking charge of all excess income until the subsidy is paid off. This would be in strict agreement with all our experience of the relative advantages of private versus British Government enterprises.

Moreover it is infinitely better to employ men for eight months of the year in the woods, and four months in the hay and corn harvests, \&c., during which farmers are distracted by the very scanty supply of mostly incompetent labour. Still it is most sincerely to be hoped that something may come of this magnificent report of the Royal Commission.

It may be of interest to close this chapter with a few notes as to what trees can clo in the way of making wood, even in our own British Islands.

At Auchendrane in Scotland there are certain Scotch firs, planted in 1707 , to commemorate the Union of the Parliaments. One of these trees is now 87 feet high, and has a girth 5 feet from the ground of 10 feet 3 inches. This tree seems to have been increasing in girth at the rate of .55 inch per annum.

There is another specimen at Benmore which is 96 feet in height.

At Auchendrane there are also a row of "Union" silver firs planted at the same time (1707), and one or two other fine silver firs. The tallest was i I o feet high (flower garden) in I905. Another (the Doctor) is I I I feet, and one of the Union trees is 96 feet. But the finest silver firs in Scotland are probably two at Rosneath, which are I 8 and ro6 feet respectively (but of which the age is not accurately known), and two at Camstradden Luss which are 125 feet and 105 feet high. The girths of these great Rosneath trees are 2 I feet II $\frac{1}{2}$ inches and 22 feet $4 \frac{1}{2}$ inches. 


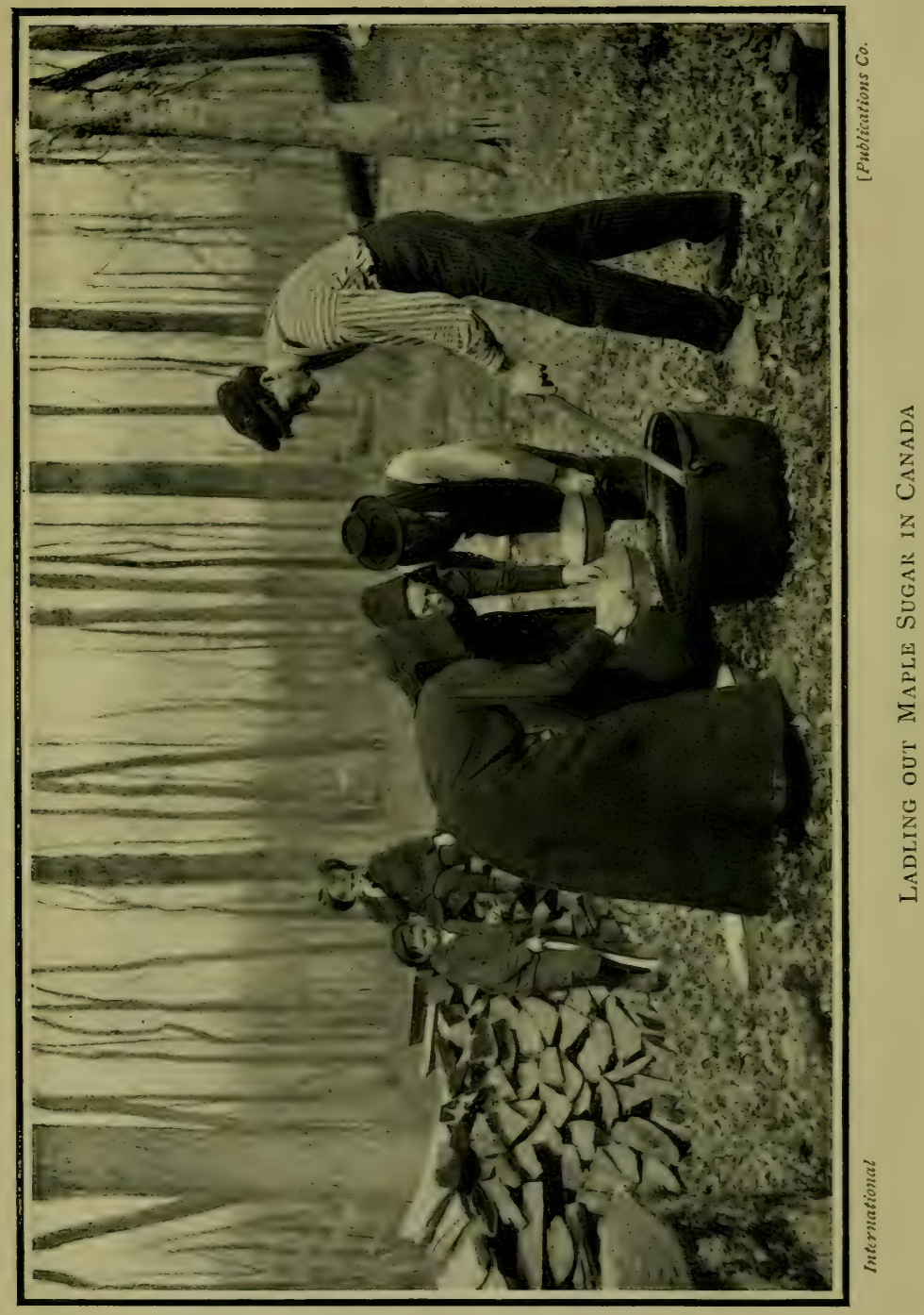





\section{Conifers}

The rate of increase shows considerable variation (see below).

InCReAse in Girth in Inches per Annum.

\begin{tabular}{|c|c|c|c|c|}
\hline & Mauldslie. & $\begin{array}{l}\text { Renfrew. } \\
\text { shire. }\end{array}$ & Ayrshire. & $\begin{array}{l}\text { Dumbarton- } \\
\text { shire. }\end{array}$ \\
\hline $\begin{array}{l}\text { Pinus silvestris (Scotch pine) } \\
\text { Silver fir } \\
\text { Cedar of Lebanon } \\
\text { Yew } \\
\text { Sequoia gigantea (1891-1903). }\end{array}$ & $\begin{array}{c}\cdots \\
\cdots \\
\cdots \\
3 \\
3.50\end{array}$ & $\begin{array}{c}\ldots \\
.67 \text { to I } \\
.28 \text { to } .34 \\
\ldots\end{array}$ & $\begin{array}{c}.55-.75 \\
.69-1.22 \\
\cdots \\
\cdots \\
\cdots\end{array}$ & $\begin{array}{c}.51 \\
.50-.80 \\
.85-1.25 \\
\ldots \\
\cdots\end{array}$ \\
\hline
\end{tabular}

In Germany there have been many careful researches as to the growth of trees, as is shown by the following table : * 9

\begin{tabular}{|c|c|c|c|c|c|c|c|}
\hline & & Heights & $\begin{array}{l}\text { in Metres a } \\
\text { Ages of }\end{array}$ & at the & Tallest & & \\
\hline & most rapid. & so Years. & 50 Years. & roo Years. & & & \\
\hline Pinus silvestris & $6-25$ & $\cdot 7-3 \cdot 7$ & $7.9-19.8$ & $\begin{array}{l}13 \cdot 5^{-29} \\
\left(44^{\prime}-94^{\prime}\right)\end{array}$ & $48 \mathrm{~m}$. & $\begin{array}{l}600 \\
\text { years }\end{array}$ & $\begin{array}{l}\text { I metre } \\
(39.37 \text { in.) }\end{array}$ \\
\hline $\begin{array}{l}\text { Pinus nigra var. } \\
\text { austriaca }\end{array}$ & $\ldots$ & $\begin{array}{l}\text { (2.5 } \\
\left(5^{\prime}\right)\end{array}$ & $\begin{array}{c}(23-15) \\
10-11 \\
\left(32^{\prime}-35^{\prime}\right)\end{array}$ & $\begin{array}{c}144-18 \\
17-18 \\
\left(56^{\prime}-59^{\prime}\right)\end{array}$ & $\begin{array}{l}35 \mathrm{~m} . \\
\text { (1 } 14 \mathrm{ft} .)\end{array}$ & $\begin{array}{l}600 \\
\text { years }\end{array}$ & $(39.38$ (11.) \\
\hline Pinus pinaster. & $\cdots$ & $\begin{array}{l}3-4 \mathrm{~m} \\
\left(9^{\prime}-12^{\prime}\right)\end{array}$ & $\begin{array}{l}8-10 \mathrm{~m} \\
\left(26^{\prime}-32^{\prime}\right)\end{array}$ & $\ldots$ & $\begin{array}{l}25 \mathrm{~m} . \\
(8 \mathrm{r} \mathrm{ft} .)\end{array}$ & $\begin{array}{l}400 \\
\text { years }\end{array}$ & $\begin{array}{c}0.75 \mathrm{~m} . \\
(29.67 \mathrm{in} .)\end{array}$ \\
\hline Pinus cembra & $\begin{array}{c}150-250 \\
\text { years }\end{array}$ & $\begin{array}{c}.01-.028 \\
\left(3.9^{\prime \prime}-10.9^{\prime \prime}\right)\end{array}$ & $\begin{array}{l}1.7 \\
\left(5.6^{\prime}\right)\end{array}$ & $\begin{array}{l}3.7 \\
\left(12^{\prime}\right)\end{array}$ & & $\begin{array}{c}600 \\
\text { years }\end{array}$ & \\
\hline Pinus strobus & 20 years & $\begin{array}{c}3-5 \\
10^{\prime}-16^{\prime}\end{array}$ & $\begin{array}{r}19-24 \cdot 6 \\
\left(6 a^{\prime}-80^{\prime}\right)\end{array}$ & $\begin{array}{l}33.2 \\
\left(\mathrm{IOS}^{\prime}\right)\end{array}$ & $\begin{array}{l}76 \mathrm{~m} . \\
(247 \mathrm{ft} .)\end{array}$ & $\begin{array}{c}460 \\
\text { years }\end{array}$ & $\begin{array}{c}\text { r.6o m. } \\
\text { (63.99 in.) }\end{array}$ \\
\hline $\begin{array}{l}\text { Cupressus sem- } \\
\text { pervirens }\end{array}$ & $\cdots$ & $\ldots$ & $\ldots$ & $\ldots$ & {$\left[\begin{array}{l}52 \mathrm{~m} . \\
(169 \mathrm{ft} .)\end{array}\right.$} & $\begin{array}{l}3000 \\
\text { years }\end{array}$ & $\begin{array}{c}3.2 \mathrm{~m} . \\
\text { (1 } 25.98 \mathrm{in} .)\end{array}$ \\
\hline
\end{tabular}

* Kirchner Löw and Schroter, l.c. The work by Elwes and Henry, which gives many details for English trees, is unfortunately not accessible to the author. For the rates given for silver firs, Scots firs, \&c., the author must express his hearty thanks to Mr. Renwick for notes and reprints. ${ }^{10}$

1 Schimper.

* Dengler.

7 Masters.

${ }_{10}$ Renwick.
2 Mey.

5 Sargent.

${ }^{8}$ Haberlandt.
3 Rikli.

6 Cieslar.

${ }^{9}$ Kirchner, Löw, and Schroter. 


\section{CHAPTER XXII}

\section{ARABLE LAND}

IT is extremely difficult to realise the sort of country which our forefathers have made into the England of to-day.

It is quite unusual to find even a few square yards which have never been "huzzed and maazed" with the plough, altered and transformed by scientific and other manures, or grazed and depastured by cattle, sheep, donkeys, horses, and swine.

England seems to have been a wild woodland of badly grown oak forest, with fern brakes or dense tangled thickets of blackthorn and bramble. On the hills there would be great moors, sometimes with heather 7 feet high. The valleys were broad marshes and fenlands, with occasional patches of alder, birch, and willow, and interrupted by old backwaters and lagoons, which were fringed with graceful thickets of bulrushes and other reeds.

The change of a country like this to the "awful orderliness" of modern England was no easy matter. Strenuous labour, perhaps continued for several generations, was required before this savage natural land became good arable.

If in the National Gallery one studies carefully the landscapes painted about $\mathrm{I} 789$ to $\mathrm{I} 8 \mathrm{IO}$, it is at once obvious that the England of that day was not in the least like that of 1909 .

The roads were mere mud. To be "stuck in the mud" was no unusual experience for gentlemen's 


\section{Arable Land}

carriages and farmers' carts; even in Burns's days, horses are said to have been drowned not in fords but actually suffocated in the mud of the King's highway!

Thorn scrub seems to have been very common and there were very few enclosures. Such agriculture as did exist seems to have been of a very pettifogging character.

This subject is a fascinating one, and also of great practical importance; but we have no space here to treat it adequately.

At a very much earlier period in Roman times the Britons seem to have practised "nomadic agriculture," that is, they burned down stretches of the forest or scrub, and sowed corn on it until the land was absolutely exhausted. Then it was left to itself and grew weeds, thorny bushes, bracken, and anything that could escape the ravages of numerous grazing animals, until it was again fit to be burnt and resown. More reasonable systems were beginning to prevail when the Saxons had conquered the country.

King Alfred says: "Sethe wille wyrcan wast baere lond, ateo hin of than acre acfest sona fearn, and thornas and figrsas swasame weods." Alfred is pointing out that if a man wants to work waste land, he must clear off from his acre the bracken, furze, thorns and weeds. He was not to cut and then burn away the rubbish. That method, as the Saxons had probably discovered, destroys all the good humus that has accumulated since it became waste.

Tennyson's northern farmer speaks of the reclamation of Thornaby Waste, and we hear of his "stubbing up " the furze just as King Alfred recommended. In our own times there are not wanting traces of this original sort of agriculture.

In Clare Island and Inishturk in Ireland, each farmer 


\section{Arable Land}

sows an acre each of oats, rye, and potatoes. The ground is manured with seaweed brought from the seaside, and is not enclosed in any way. The lean cows, sheep, and the mare and foal which are running free in the common pasture, are always endeavouring to sample these crops, and the united efforts of all his children, and of his many dogs, are required to keep them away.

The people are extremely poor, but there is something homely and attractive about the old-fashioned, little two-roomed hovel, with its roof of straw held down by ropes and stones. There is a kitchen-pen for the cattle, and a snug place for the pig, beside the fire of peats, which is in the centre of the hut, and on the ground.

Even in Devonshire one finds in Braunton Great Field some sort of guide as to what was once a very common system of agriculture. This field is said to contain 365 acres subdivided into an enormous number of little strips and plots held by different villagers.

In former days there would be huge unenclosed wastes or commons surrounding the village arable, upon which the goats, sheep, cattle, and horses would run half wild and without any attention. After harvest they would probably be allowed to graze on the arable land. This sort of agriculture exists more or less all over Southern Europe. It is the system in Spain, where one finds rich alluvials or vegas intensely and carefully cultivated, but without any enclosures or hedges. The cattle, sheep, pigs, horses, and mules are pastured on the hills, which have been so much grazed and spoilt by over-stocking that the food is of the most scanty character.

There are authorities, even to-day, who profess to admire this venerable system of agriculture, which is 


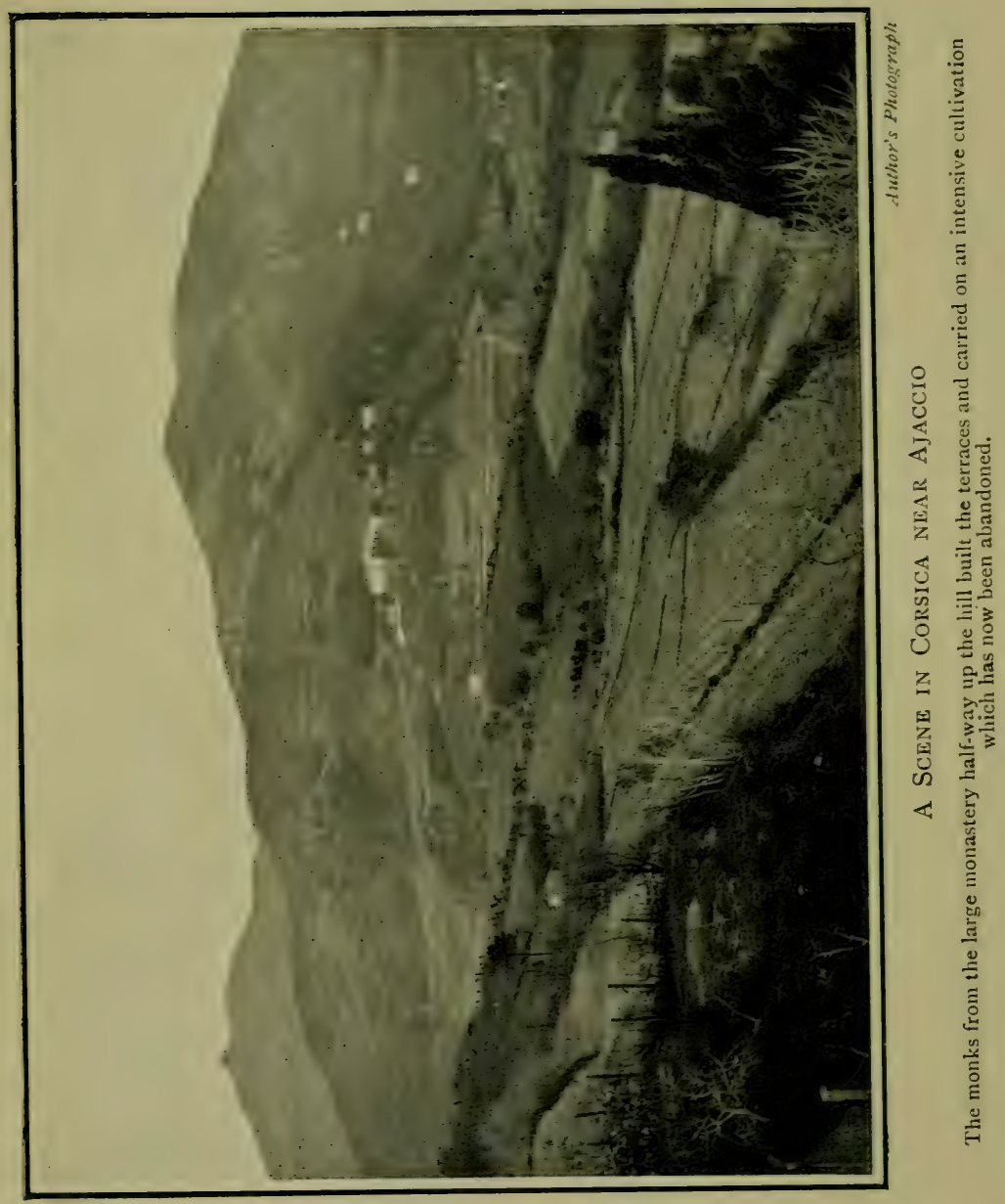





\section{Arable Land}

neither Saxon nor Celtic, but probably Neolithic. Yet even in a very sparsely settled country it was not surely so very admirable.

The labourer had to trudge over miles daily to get to his own special plot. He could not permanently improve the soil, for the plots were usually changed every year. His cattle could neither be properly fed or in any way improved by breeding or selection.

The enclosure of England was a wise and necessary proceeding. It required strong nerve and even brutality to carry it through, but the result has been to increase the harvests beyond calculation, and to afford a livelihood to many thousands more than could ever have existed on the Inishturk or Braunton system.

Even in Saxon days there had been, as we have seen, some progress in the first reclaiming of waste.

But the "stubbing up" and removal of the wild vegetation is but a very small part of the labour necessary. Every field in England has been drained; the ground has, in most places, been more or less levelled. Stones have been collected and taken off, and especially, for it is the one essential point in which civilised efficient agriculture differs from more or less savage backwood methods, every field has been enclosed. There were no wire fences in the days when England was made, such as now make enclosure a very much simpler affair for Australian, Canadian, or South American settlers. These enclosures were ditches which had to be dug with an immense expenditure of labour, or rough stone walls, or earthen banks planted with hawthorns.

The work expended on an acre of land in draining, ditching, levelling, clearing, and fencing must have been enormous. However low one reckons the cost of labour to-day, the present value of an acre of ordinary land would be very much less than the cost of making it. 


\section{Arable Land}

But even when the land was made and cleared, and placed under crops, new difficulties began to appear. In most places the soil was utterly exhausted after three or four years under wheat or some other cereal.

This, however, is not always the case, for in the Rothamstedt Reports one finds that one of the plots which was never manured had grown wheat regularly for sixty-one years, and even then yielded thirteen bushels per acre. Cases have been recorded in New Zealand of continuous high yields of wheat on the same land.

But that is most unusual, for even on the richest virgin soil the tendency is always for the corn to become less and less productive, whilst weeds increase and flourish so vigorously that they eventually kill it out altogether.

In an ancient, prehistoric lake village in Italy, weeds were found amongst the villagers' corn, and it is even supposed that they got their seed from Egypt, for one of these weeds is an Egyptian and not an Italian plant.

The origin of our common weeds is a very difficult question to solve. Some are quite unknown in a wild state, and their original wild ancestor has probably died out altogether, as, for instance, Lamium amplexicaule. Others are found both as weeds and as, e.g., woodland plants. This is the case with Lamium album, whose range as a weed is far outside its range as a wood plant. ${ }^{1}$ Some weeds certainly come from warmer and drier countries, but, as has been already shown (see p. 95), many of them are almost cosmopolitan and may have come into existence anywhere.

On the bare soil which primitive man had prepared for his crops, almost any wild plant would grow, and would find the position much more comfortable than its ordinary habitat.

To-day we find plants of the South, such as Linaria minor, doing very well on the dry cinders of railway lines, 


\section{Arable Land}

or Senecio viscosus luxuriating on the Glasgow rubbish heaps or "blaes." Sea-side plants, such as Euphorbias, Chenopodiums, Silverweed, are very common as weeds.

One of the very worst weeds in America is Salsola kali, which is a sea-side plant with us, but also occurs abundantly in the salt deserts of Central Asia.

But weeds may come from anywhere; thus, for example, in an orange garden at Tripoli, in Africa, I found quantities of an American nettle (U. membranacea).

Spain is full of South African and American weeds growing so vigorously that one would never suspect them to be foreigners.

So also in the United States, one finds in cultivated ground the poppy (Papaver dubium), an European immigrant which is travelling westward at the rate of five miles in three years, also the Mexican P. argemone from the tropics of Central America, and Abutilon avicenniæ, which is from British India.

As a rule, weeds in their native lands belong to "open " floras, that is, grow apart from one another and sparsely or scattered. Being hardy, stubborn, inured to dry ground, and able to grow rapidly whenever they have the chance of doing so, they may be of very great importance in colonising the ground.

An interesting case of good work performed by weeds is recorded from Wärdale (Trondjhemfjord) by Resvoll. A serious landslip occurred there during 1893 , and in consequence the valley was entirely plastered over by a surface of raw, unworked clay which covered it for a space of 8000 yards long and about a thousand wide.

Five years afterwards it was green and fresh, with a fine and thick growth of plants, amongst which honourable mention should be made of coltsfoot, knotgrass, (Polygonum aviculare), mouse-ear chickweed, and sheep's sorrel (R nex acetosella). 


\section{Arable Land}

These weeds and a few other plants were colonising the ground and making it fit for better kinds of vegetation. It would become, if left alone, a bushy meadow or heather moor.

Weeds are remarkable for combining in a most unusual way the very best characteristics of Conservativism and of advanced Radicalism. They are stubborn and tenacious, holding on obstinately to what is good, but they are always ready for new adventures and quite adaptable to new conditions.

Thus, for instance, when a foreign weed, Vicia orobus, established itself in Germany, it was found that it flowered twice in spring and in autumn. The spring form is taller than the surrounding herbage, and is very shaggy or hairy, apparently because it requires protection against the inclemency of the weather. But the late flowering autumn plants have no hairs, for they are not taller than their neighbours, and require no such help. ${ }^{2}$ It is of course quite usual to find our weeds flowering at different seasons. But they are specially ingenious in the exact way in which they time their appearances, so as to coincide with our ordinary agricultural crops.

Some of the smaller corn weeds grow up with the corn, but take care to shed their seed before it is ripe and ready for harvest. Those which are about as tall as the corn itself seem to ripen with it, so that their seeds accompany the grain and are thrashed out and sown again with it. Others again are taller than the oat stalks, and their fruits and seeds are distributed before harvest. Then again there are others which come up in the bare stubble fields, and so can shed their fruit without any interference.

There is just the same ingenuity in the case of those which are found in turnip or potato fields. Some are very quick and grow ahead of the turnips; others may 256 


\section{Arable Land}

wait till the crop is removed, or the potato-stalks are rotting on the ground.

$\mathrm{Mr}$. Ridley records an unusual exactness in flowering for certain orchids and Dipterocarps near Singapore. A Dendrobium flowers with the greatest punctuality every six weeks. On the proper day every plant in the clistrict is white with blossom, but next day one can find nothing but withered flowers. This habit seems also to be common with Bromheadias. ${ }^{3}$

It is really just as wonderful to find in one field, thistles, Scleranthus, and many other weeds, all shedding their seeds within exactly a day or two of one another.

It is more difficult to explain why it is only in some years that almost every bamboo plant is found in flower, or why certain Shoreas and Hopeas should regularly blossom within one or two days of one another, at intervals of six years.

Weeds have several very remarkable peculiarities, besicles their ingenuity in the way of flowering exactly when it suits them best. Most of them possess underground runners or rhizomes or fleshy roots, which are placed just too deep for the plough or spade to interfere with them.

Bishop's weed, coltsfoot, thistle, bracken, and several others cannot be eradicated by the plough, for their starch-filled stems or roots are just out of reach. Even if one could manage to drive a cultivator through these roots so as to cut them in pieces, this would not be of much use. It has been shown that a piece of these runners (thistle), one quarter of an inch in length, is capable of producing a complete new plant.

It is very disheartening to try and remove the thistles from a field by mowing them down. But it can be clone; for, if the thistles are cut over three or four times a year, and this continued regularly for four years, 


\section{Arable Land}

they become sickly and disheartened and may die out altogether. But if only one plant manages to flower and shed its seeds, the whole work may have to be done all over again. "One year's seeding makes at least seven years' weeding."

One very strange way of destroying weeds is said to be in use on an American railway (Illinois Central). A brush heavily charged with electricity is attached to a railway truck, and drawn along the track at about 8 inches from the ground. ${ }^{4}$ Every plant touched by it turns black as if frozen, and dies. It used to cost ten dollars per mile to destroy these weeds, but now about five miles can be done in an hour, and at very little expense.

Another method which is often employed in this country is to spray the weeds with a solution of copper sulphate. In dry weather during May and June, young charlock plants may be nearly killed out by spraying. But nowadays great care is taken to insure that no weeds are sown along with the corn or other crops. Many samples of seed corn were found to be full of the most dangerous pests of the farm. A pound of "clover seed" was examined at the New Jersey Experimental Station which contained I 4,400 seeds of no less than forty-four distinct and separate weeds.

But even in the best and most carefully tended agricultural land, the dormant possibilities of evil are quite incalculable. Dr. Buchenau counted the number of weeds which appeared between May and December of I903, in a small garden which was only five square yards in extent, and yet 2683 germinating weeds were discovered upon it during those months. ${ }^{5}$

The farmer has many other difficult tasks beyond those which we have mentioned. It is no easy matter to keep down the weeds, to keep up fences, drains, and 


\section{Arable Land}

ditches, and of course to begin and finish every agricultural operation at exactly the right moment. But he must return to the land those salts of nitrate, phosphates, and the like which he removes in the shape of corn and potatoes or root crops. The great work of Lawes and Gilbert is still carried on at Rothamsted and in other experimental stations. But the study of agricultural manures has become a special science, for which we have no space in this work.

In spite of these experiments and the extraordinary skill and science expended on our arable land, there are two truths which ought to be mentioned.

No country in the world, neither France with its sunny climate nor Germany with its applied science, not even the virgin soil of our Colonies and the United States, can produce so much per acre as Great Britain.

The average number of bushels per acre of wheat, oats, and barley, the tons of turnips, mangolds, and potatoes raised per acre in Britain are almost in every single case the very best for any country which has reliable statistics. Denmark is the only exception, and that only for certain crops and occasionally. This of course is just as it should be, and ought to make us extremely careful about any interference with our system of agriculture. Any one who thinks and studies about the food-supply of Britain in time of war will assuredly pass a sleepless night or two, for even the large supply per acre which our well-tended arable produces is not nearly enough for $44,000,000$ people. In I 908 we got 5,820,600 cwts. from Australia, 2,948,000 cwts. from India, I6,8 10,984 from Canada, which makes in all about $23 \frac{1}{2}$ per cent. of our imports ( 109, I 47,808 cwts.). Our own home-grown wheat amounts to about $68 \mathrm{lbs}$. per head of population, and the imported wheat is 284 lbs. per head. ${ }^{6}$ 


\section{Arable Land}

The other extraordinary fact is that our arable land is yearly diminishing in area. It does not pay to grow corn crops and roots for modern prices and with modern taxes. Therefore these scientifically built up and most productive fields are gradually changing into pasture and the area under corn is incessantly shrinking.

The average yield per acre is, taken all over England, $31 \frac{1}{2}$ bushels, in Australia 9.03 bushels (varying from 1.24 bushels to 21.86 in Tasmania, I90I-I902), in India Ir.16 bushels, and in Canada 17.83 bushels. Irrigated land at Ajmere Merwana in India has given as much as 34 bushels per acre, and even higher yields are by no means unusual in favoured districts.

If our farmers could have foretold the sudden rise in the price of wheat to 48 shillings per quarter in April I909, there would have been no shrinking in the area of our cornlands in 1908 , but then American speculators would not have been able to make $£$ roo,00o in a day and $£_{2}, 000,000$ in a week or two!
1 Dunn.
* Ridley, Brandis.
2 Resvoll.
5 Anon.
${ }^{3}$ Kraus.
6 Humphries. 


\section{CHAPTER XXIII}

\section{GRASS}

OF all plants there are perhaps none so full of interest and so wonderfully designed as the great grass family.

It is quite a cosmopolitan order, varying in the most remarkable way to suit the exigencies of almost every climate in the world. The tree-like grasses such as bamboos, and the like, force themselves on one's notice everywhere in or near the tropics. The beauty of a great feathery, gracefully-drooping bamboo clump cannot be overlooked. In Chili one may have to hew one's way at the rate of fifty yards an hour through the Chusquiea, another climbing grass, which winds round tall trees and hangs in graceful folds in amongst the foliage everywhere.

Near the top of Ruwenzori it takes nearly a day to pass through the bamboo zone ; generally dark, damp, dripping, and miserable, and where the ground is covered by viciously stinging nettle-like plants.

There are other weird grasses growing over many stretches of the Australian bushes into which no sheep are ever allowed to go on account of the long spiny tips of their fruits, which work themselves into the wool. They even pierce the skin and sometimes kill the sheep, but of course its fleece is so matted and torn and penetrated by the wiry winding threads that it is of no value whatever. But grasses of this morose, solitary and wicked disposition are very unusual. The vast majority of them are exceedingly benignant; indeed it is they who make possible all sorts of civilisation, for they constitute by far the larger part of the food of mankind and also of his dependent domestic animals. 


\section{Grass}

Rice, wheat, oats, Indian corn (not to speak of barley) are essential to man's existence. Each might perhaps be said to support a particular kind of man, and perhaps to be responsible for some of his characteristics.

The Hindu, Fellahin, Malagasy, or Chinese paddyfield means long monotonous dabbling with loathsome mud in a hot and moist climate, and does perhaps really produce a mild, not very brave, industrious disposition very different from that of the northern oats, of which only a small crop can be wrested by incessant fighting with a stubborn soil in a climate which very few can love and none praise, at least honestly.

Even the Zulu and Kaffir, nourished on milk and maize, with perhaps a little millet, differ entirely from rice-fed Asiatics. But we cannot here enter into these abstruse questions.

An order so widely distributed and so various in its demands for rain, warmth, and sunshine must be remarkable for something particularly ingenious and efficient in its outfit.

The grasses are in fact very different from all other orclers, and only show a very distant relationship to the Cyperaceæ.

Perhaps the most characteristic point about them is the manner in which the young growing stem is protected. When the corn has germinated in early summer, it remains for quite a long time with only the leaf-tips projecting above the earth. The young stem and future ear are buried and enclosed in a series, one within the other, of cylindrical sheathing leaf-bases. These "nests" of enveloping leaf sheaths are extremely efficient. They are thin, tough, and hard, and completely enclose the young bud; being bad conductors of heat or cold, and full of flinty secretions, they also protect it from changes in temperature, from drought, and from insects. 


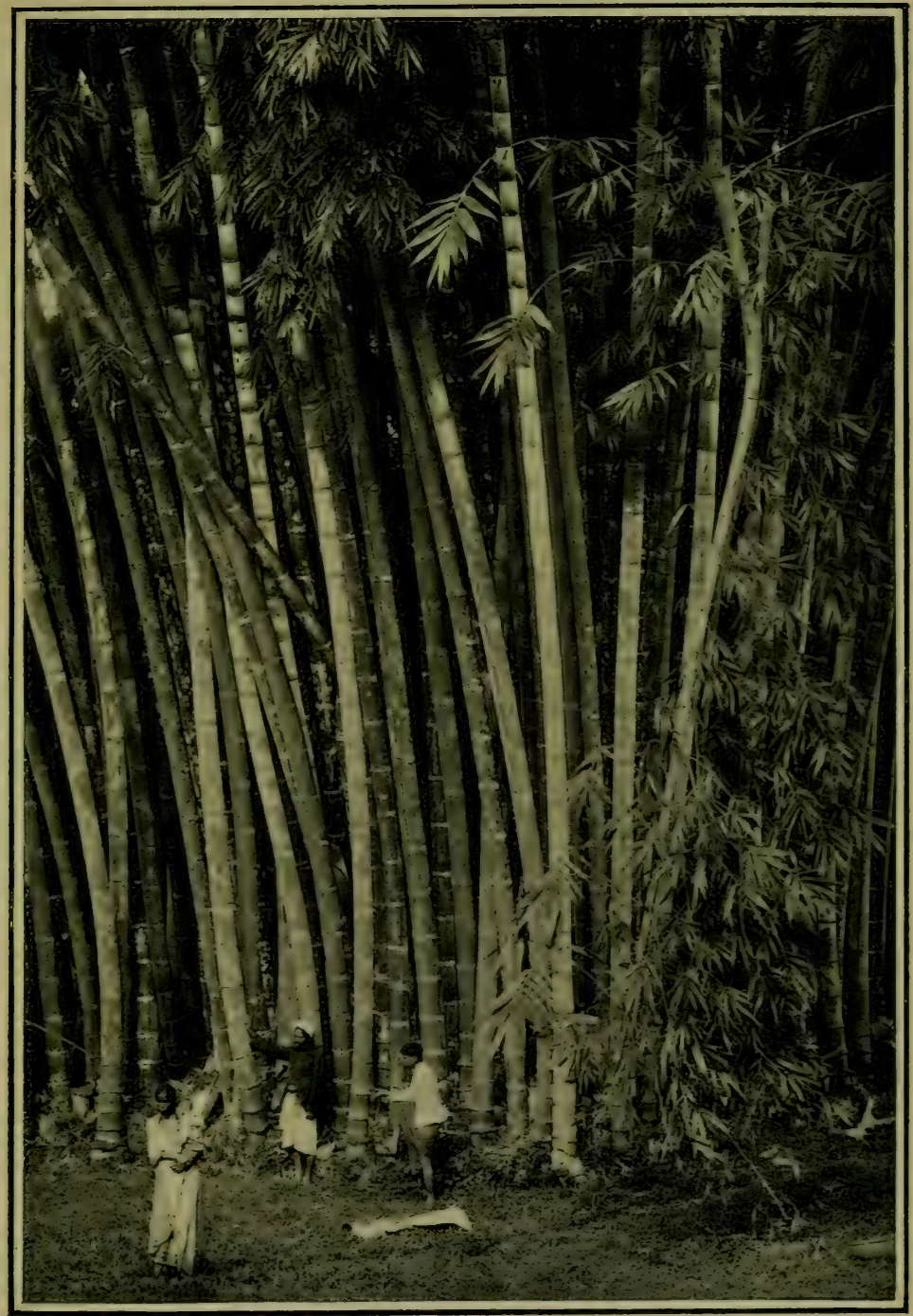

Stereo Copyright, Underwood \& U.]

[London and Nerv York

The Giant Bamboo

This sometimes grows to a helght of from 50 feet to roo eet. These specimens are growing in the Peradeniya Gardens, near Kandy, Ceylon. 



\section{Grass}

But the adaptability of the grass is better realised when such a bud as this begins to "shoot." The stem segments or internodes develop between the nodes or leaf insertions. It springs up like a telescope being pulled out. Should the weather be dry and cold, the segments are very short, and the grass is low and stunted. But in a fine, moist, low-lying meadowland, the tall graceful stems may spring up to heights of five or more feet, and the amount of green leaf and stem per square foot becomes very remarkable.

But the grass bud is by no means confined to its one main flowering shoot. When the seed germinates, it puts forth its first feeble tentative rootlet, which fixes itself with root-hairs in the soil. The next step is to develop its first internode, which gropes its way upwards carrying the bud towards the light, and until it has reached a definite position just a short distance below the surface.

If the soil is rich and there is plenty of moisture, the roots are actively working and food material is accumulating in the bud. Then, however, one finds new buds are being laid off within the leaf-sheaths.

In very favourable soil no less than one hundred of these stems, each with its ear of corn, springs from a single seed! In this way a regular "tussock" may be formed in one season by a single seed.

The strong tussocks of hard, wiry grass-leaves which make up the vegetation of a steppe are of course the result not of one but of many years' growth, but yet each represents the colony due to a single seed.

The microscopic details of the leaves of some steppe grasses show the most exquisite contrivances for not only preventing too great a transpiration, but for making the foliage as inedible as it possibly can be. In a general way one might say that the upper surface of such leaves consists of alternate strips of hard cells forming length- 


\section{Grass}

wise ridges, and of delicate-walled collapsible cells in the grooves. In dry weather these latter sink or collapse, and the leaf is rolled or wrapped round into an almost woody cylinder which no ordinary animal could possibly desire to eat.

So it is that in the dry climate of the Argentine, in spite of bitter winds and blazing sunshine, a rolling waving sea of grasses covers the whole country as far as the indistinct and misty horizon. Monotonous as such steppes may be, they have a charm of their own, varying with the changing of the seasons. In early spring it is all a bright bluey green; later, as the sun hardens and dries the leaves, it turns to a brownish or yellowish green, but when the white flowers are fully out it is a rolling waving sea of shining silver.

The flowers of grasses are always considered difficult to examine, and they are not favourites for young and untried botanists, for they are certainly very dry, very minute, and difficult to see.

Each floret, with usually three stamens, an ovary with white and feathery stigmas, and two small scales (lodicules) is packed away between two neatly fitted bracts. The outer of these (flowering glume) is more or less boat-shaped, and the other, which is flat, fits into the boat, being, as one might say, like its deck.

At the right moment (about eight in the morning for Poa annua ${ }^{1}$ ) the two small scales or lodicules swell by absorption of water. This forces up the "deck," and the three stamens begin to grow very rapidly. In from ten minutes to half-an-hour they will elongate to about four or five times their own length, and hang out over the edge of the flowering glume. Sometimes one can make the spikelets open and flower simply by stroking them lightly between the fingers or by shaking the stalk. One observer saw a whole field of rye suddenly blossom when a gentle breeze began to blow across its surface.

$$
264
$$




\section{Grass}

But the best way is to bring a few different sorts of grasses into the house and leave them with their stalks in water. They are soon covered with pollen, and one can see the neat little contrivances to insure crossing and also distinguish the colours of the grass flowers.

These colours are far too delicate to appreciate when one is simply walking beside a hayfield. When seen close at hand, one is astonished at the variety of the tints of pink, silvery green, browns, and purples. The bright yellow pollen and fresh green of the leaves set them off artistically.

The pure-white, feathery stigmas project also out of the covering glumes, and are well arranged to intercept the pollen. It is not generally known that insects do visit the flowers of some grasses, and especially sweet vernal, so that these colours are not altogether wasted.

The exquisite engineering of a fine grown flowering stalk of even the little Poa annua can only be appreciated by closely observing it. All ordinary grass haulms are excessively strong, though very thin, and the graceful way in which the relatively heavy spikelets are hung on their slender stalks is most remarkable. In a strong wind they are always in motion, bending and waving about ; each spikelet, with its small conical base, swings into the direction of the wind and hovers about in it.

The stems of grasses are hollow, and the mechanical tissue is arranged in a ring near the outer circumference. Their strength is enormous if one remembers the very narrow diameter and the height of the columns, with the weights of fluttering leaves and heavy little spikelets.

Over-fed and pampered grasses such as our corn and wheat are often beaten to the ground by heavy rain or hail, but the grass is prepared even for such accidents as these. The base of the lower leaf-sheaths is thick and swollen where it joins the stem. When the grass stem lies upon the ground, the attraction of 265 


\section{Grass}

the earth affects these basal parts. The side next the ground grows rapidly, whilst the upper part shrinks and contracts. The result is to twist up the whole grass stem, and it becomes, if not quite upright, yet lifted up again, so as to be almost in its natural position.

When fully ripe, the grains of grasses are scattered by some modification of the protecting bracts.

The steppe grasses often possess a long slender awn which is very hygroscopic. It twists up in dry weather and untwists again when the atmosphere becomes moist. The tip of the spikelet is hard and sharp, and there are also short stiff hairs on its base. When such a Stipa fruit is lying on the ground, its long awn gets entangled in the grasses near it. Every twist or untwisting forces the point into the ground, and as the stiff hairs prevent its being pulled out, it is driven right below the surface.

If it should have fallen on the back of a sheep, the result is often that the seed is driven right through the animal's skin, and it may cause a serious wound or even death.

It is a fact that sheep are killed in this way, indeed no less than four kinds of grass are guilty of sheepkilling. Stipa capillata commits these murders in Russia, and S. spartea also in North America ; Aristida hygrometrica in Queensland, and Heteropogon contortus in New Caledonia have also been convicted of this crime.

But we must turn to those grass-problems which are of real importance to mankind. Natural grass occurs under the most different conditions as regards rainfall and temperature, and then again there is the very difficult question, what is natural grass-land? There are, of course, many sorts of grass-land. The Phragmites thickets grow actually in water; bank-foot colonisers like Phalaris arundinacea or Glyceria aquatica are also more or less under water.

Such forms as Aira cæspitosa grow just outside the 266 


\section{Grass}

rushes near sheets of fresh water, and other grasses also occur in wet places̀. Then, on the other hand, the bent-grass, Psamma, grows in very dry ground, and a sand-dune overgrown with it is not unlike a steppe. All these are natural grass-lands.

But in the United States the prairie, which is a typical grass-land, is bounded on the east or Atlantic side by a country which is or used to be a thick and well-grown forest. On the Rocky Mountains or western side, the prairie becomes gradually more and more steppe-like and arid until real desert begins. It is just the same with the pampas of the Argentine. In the west at least it shades off into a desert, whilst on the east there are or used to be the forests and woods of the Rio de la Plata.

It seems very probable that a considerable proportion of the eastern prairie, and very likely of the Argentine pampas as well, was once woodland or forest; at any rate many American botanists seem to think so. The Indians used to set fire to the woods in order to obtain land for cultivation. Prairie fires, happening in a late and dry summer when everything is scorched and inflammable, would inevitably prevent the growth of woodlands. If this is so, it is only a natural grassland in the sense that natural man, not the intelligent and civilised variety, has produced it.

The author has himself seen the effect of grass fires upon the African plateaux in Uganda. It is not a very alarming or dangerous spectacle, for it is just an insignificant line of blazing grass which may be sometimes checked by a hard-trodden native path, and which one can step over without any danger.

In that district, each river is bordered by a fringe of woodland; the fire does not usually destroy the foliage but only singes the outlying branches of the outside 


\section{Grass}

shrubs and trees. But on the dry levels it prevents any ordinary tree from growing. One sees small shrubs, ten years old or more, which have patiently developed in every year a set of branches and stems which have been annually burnt away again.

Some trees are, however, able to withstand the fires. The curious tree Euphorbias are almost fire-proof, and there are a very few others with a thick gummy bark that are not destroyed. Such trees endeavour to form a forest, and might perhaps in time form a nucleus of vegetation sappy and fresh enough to resist the fires. ${ }^{2}$

After such a fire the ground is black with cinders, and every breeze fills one's eyes, ears, and nostrils with half-burnt dust. Yet it is extremely beautiful, for after a shower of rain brilliant little flowers are springing up everywhere, and later on small green leaves begin to appear from the blackened ground.

But such fires are not confined to the table-lands of Uganda. The tall elephant grass in the Semliki valley is good pasture when young, for the cattle grow fat and well-nourished upon it, but it rapidly springs up to a rank growth of 7 feet or more in height and is regularly burnt by the natives. When fully mature it is so strong and dense that the cattle cannot get through it at all, but the waste of valuable feeding stuff by the fires is of course very great. All over South Africa the natives as well as the Boers, who are not much beyond the natives in their methods of agriculture, regularly burn the long dried grass towards the end of the dry season. In Natal this custom has, I think, been forbidden, but it is still far too prevalent.

The waste of good vegetable work involved by such proceedings is most reprehensible. Not only are many young plants burnt up altogether, but the surface layers of leaf-mould, dead leaves, twigs, and many 268 


\section{Grass}

miilions of useful bacteria and insects are utterly destroyed. There cannot be any accumulation of good humus, and the grasses that eventually survive such treatment are just the sour, woody, or wiry kinds that are the least valuable of all.

When the South African veldt is enclosed and properly pastured the yield may be indefinitely increased, but that will not be for a very long time to come.

In England the best grass pastures are the rich river alluvials, which were once thickets of Phragmites or brakes of alder and willow. Next to these are the rich grazing lands, "old pastures" which have been gradually brought into perfect condition by generations of skilful farmers.

Nothing else on the farm can compare with these grass lands. Store bullocks, milch cows, and young cattle will yield a far higher profit when grazed upon them than can possibly be expected from any other farm crop.

This illustrates the truth of M. Porcius Cato's view (B.C. 234). To feed stock well was in his opinion the most certainly profitable of all agricultural operations. The next was "tofeed moderately" (that is, of course, the stock).

It is neither at all easy in such a climate as ours to make such a pasture, nor even after it has been made to keep it in the best condition.

There are the following distinct and different points which have to be carefully studied.

I. Those grasses only must be chosen which are wholesome and relished by animals.

There are many poisonous plants, such as hemlock, foxglove, Equisetum, Oenanthe, Cicuta and the like, which a curious botanist often discovers by the hedges or in the ditches of a pasture field. One would have expected that the poisonous or wholesome nature of every British plant had been definitely decided by 


\section{Grass}

experiments. That is not the case, for scientific opinion is very much divided even now as to such common plants as the foxglove.

In one of the best text-books on Agricultural Botany * we find this: "The fruits" (of the Darnel) "are said to be poisonous." Not, they are poisonous, for the question is not decided.

II. The second point is the relative value of the different grasses considered as food for stock.

The following table shows both how varied is the nutritive value, and also how different are the views of various authorities on this essential point.

One hundred pounds of hay of the following grasses will contain as follows:-

\begin{tabular}{|c|c|c|c|c|}
\hline Perennial ryegrass & I 0.2 & all & af & ter Wolff. \\
\hline Italian ryegrass & II.2 & " & " & . \\
\hline Cocksfoot & $\begin{cases}\text { II.6 } \\
7.8\end{cases}$ & $"$ & $"$ & Way. \\
\hline & $\begin{array}{l}17.2 \\
\int 10.2\end{array}$ & $"$ & ," & $\begin{array}{l}\text { Coller. } \\
\text { Wolff. }\end{array}$ \\
\hline Meadow fescue & $\left\{\begin{array}{r}6.4 \\
6\end{array}\right.$ & $"$ & ", & Arendt. \\
\hline Yellow oatgrass & 6.4 & $"$ & ", & Way. \\
\hline Timothy & $9 \cdot 7$ & ", & $"$ & Wolff. \\
\hline & 5.9 & $"$ & $"$ & Frey. \\
\hline Meadow foxtail & $\left\{\begin{array}{r}10.6 \\
6.0\end{array}\right.$ & $"$ & $"$ & $\begin{array}{l}\text { Way. } \\
\text { Frey. }\end{array}$ \\
\hline & $\int 8.9$ & $"$ & $”$ & Way. \\
\hline Sweet-scented vernal & 4.8 & $"$ & ” & Wolff. \\
\hline & ( IO & " & $"$ & Collier. \\
\hline Smooth-stalked Poa & 6.4 & ", & $"$ & \\
\hline & & $"$ & $"$ & $\begin{array}{l}\text { Way. } \\
\text { Ritthausen }\end{array}$ \\
\hline Rough-stalked Poa & 9 & $"$ & $"$ & and Scheven. \\
\hline & 6.1 & $"$ & $"$ & $\begin{array}{l}\text { Barbieri. } \\
\text { Wolff. }\end{array}$ \\
\hline Sheep's fescue & $\left\{\begin{array}{r}5.1 \\
5.6\end{array}\right.$ & $"$ & $"$ & Collier. $\dagger$ \\
\hline
\end{tabular}




\section{Grass}

These results are distressingly inconsistent. When oracles give out uncertain or directly contrary replies, can one blame the practical man for paying no attention whatever to their commands? Yet it is essential to the formation of a good pasture to have the best and most nutritive grasses.

III. Grasses vary very greatly indeed in the vigour of their growth and the amount of hay produced. Cocksfoot, for instance, has produced $27,905 \mathrm{lbs}$. per acre on rich sandy loam, as well as an aftermath of I I, 9 Io lbs. Perennial ryegrass gave 7827 lbs. per acre (when dry $3390 \mathrm{lbs}$.) ; timothy has given 40,837 lbs. ( 7,356 lbs. when dry); sweet vernal has given 7827 lbs. (2 104 lbs. when dry); sheep's fescue has given I 280 lbs. (on poor soil, Bürger).

Here again there is a great deal of uncertainty, for farmers would scarcely accept these conclusions. Timothy can hardly produce more than five times as much as the universal ryegrass. But there are experiments (those at Clifton Park), conducted at great expense by Mr. Robert Elliot, ${ }^{3}$ which also seem to shatter the reputation of ryegrass,

IV. Method of Growth. - The "tussock" form of growth is very common, but to get a really good pasture, it is necessary to have a proper admixture of those other kinds which throw out runners, These break out of the leaf-sheaths and produce, under or over the ground, a network of creeping stems from which leafy shoots spring up. Meadow-foxtail and smooth-stalked poa are good examples of these turf-forming grasses.

Then again some roots penetrate deep into the soil, exhausting the deeper layers, whilst others are surface feeders. Rough-stalked poa, e.g., will scarcely go deeper than 12 inches, whilst smooth-stalked poa will reach I6 inches, Sheep's fescue and sweet vernal are surface 


\section{Grass}

feeders, and ryegrass, cocksfoot, meadow-fescue, and timothy are very deep-rooted. ${ }^{4}$ A good pasture must have all these varieties.

V. Some grasses develop quickly and die out altogether in two or three years. Others take some time to mature, but will remain for a very long time when once established. This complicates the question, for the mixture must contain both temporary grasses to afford a crop during the first two or three years and the, others as well.

VI. Germination and good Seed.-The percentage of seeds which germinate is not always the same; it is only 80 per cent. for golden oat grass and sweet vernal, 85 per cent. for smooth-stalked poa but 97 per cent. for rough-stalked, and $9^{8}$ per cent. for timothy and Italian ryegrass. Still greater differences are probably due to the particular seed used, for selected and wellnourished seeds will produce a far finer crop than a miscellaneous sample.

VII. Perhaps the most important point of all is to thoroughly realise the different partialities and preferences of the grasses themselves. Some prefer a dryish soil of a sandy or stony character, others like a moist, damp, low-lying alluvial meadow. Some, usually the worst, grow anywhere, and do not mind whether the soil is good or bad. The difficulty of discovering these individual preferences is very great. In a general way the tall and richly productive grasses prefer and do best in good soil, while the less valuable kinds, like sheep's fescue, thrive on poor and stony ground.

VIII. Finally, there is perhaps the most important point of all, the price of the different grass seeds. These are sold by the pound. But the number of seeds in a pound varies enormously. Suppose one wants meadow fescue and notices the price to be $7 \mathrm{~d}$. a pound. This 


\section{Grass}

seems a temptingly low price, but $\mathrm{I}, 000,000$ germinating seeds would cost at that price half-a-crown.

Tall oat grass at is. a pound means $8 \mathrm{~s}$. Id. per million germinated seeds. Italian ryegrass at $3 \mathrm{~d}$. per pound means I I $\frac{1}{2} d$. per million. Smooth-stalked poa at $9 \mathrm{~d}$. per pound means $5 \frac{3}{4} \mathrm{~d}$. per million, and so on. ${ }^{5}$

Grass seeds are of very different sizes, and as one seed only is required to form a plant, fewer pounds are wanted of the smaller ones.

By this time the reader will appreciate the skill and experience of those ancestors of ours who have really succeeded, somehow or other, in forming old pastures which let sometimes at $£ 5$ to $£ 6$ per acre, and are probably not surpassed by those of any other country in the world.

Unfortunately we must confess that those old pastures were not much assisted by British botanists. Even now there are great differences of opinion as regards essential points.

Mr. Elliot's many years of careful experimenting have led to very interesting results which, if true, would revolutionise our ideas in laying down pastures. It is unnecessary to say that those expensive trials of his were carried out at his own expense. In any other country, abundant funds would have been at once provided by the Government to confirm and extend such valuable work.

Mr. Kipling says that "Providence looks after the British Government because it is so big and helpless," which we hope is true.

1 Tschermak.

${ }^{4}$ Aitken.
2 Scott Elliot (2).

5 Hunter.
3 Elliot, R. H. 


\section{CHAPTER XXIV}

\section{FORTUNATE ISLANDS}

IN the family traditions of most peoples there are usually stories of some particular Fortunate Islands where, in exquisite sunshine and eternal spring, an innocent and childlike people disport themselves amongst flowers and splendid fruit trees, earning their subsistence with the merest apology for labour, and redeemed by Nature's exuberant fertility from that drudgery which is the common lot of mankind.

The facile pens of enthusiastic, if badly informed, writers have discovered Utopias in the West Indian Islands, in the South Seas, and in the Canaries, which last appear to have been the original Fortunate Islands of the classical world.

At first sight such islands within or just outside the tropics do seem to answer the conditions of Utopia.

Fresh sea-breezes prevent the oppressive and exhausting effects of ordinary tropical heat. There are often neither mosquitoes nor malaria. The warm transparent water yields an abundance of fish, and the soil is fertile and returns abundantly for any half-hearted attempt at plantation or cultivation.

These islands are the home of the cocoanut, banana, mango, and often of the sago palm, the most abundantly productive food plants known to mankind. An acre of bananas will carry one thousand plants, which may give some 1000 to 1500 bunches in the year, which is about $9 \frac{1}{2}$ tons. The cocoanut is also exceedingly prolific, and can be used for all sorts of purposes. The bread-fruit is 


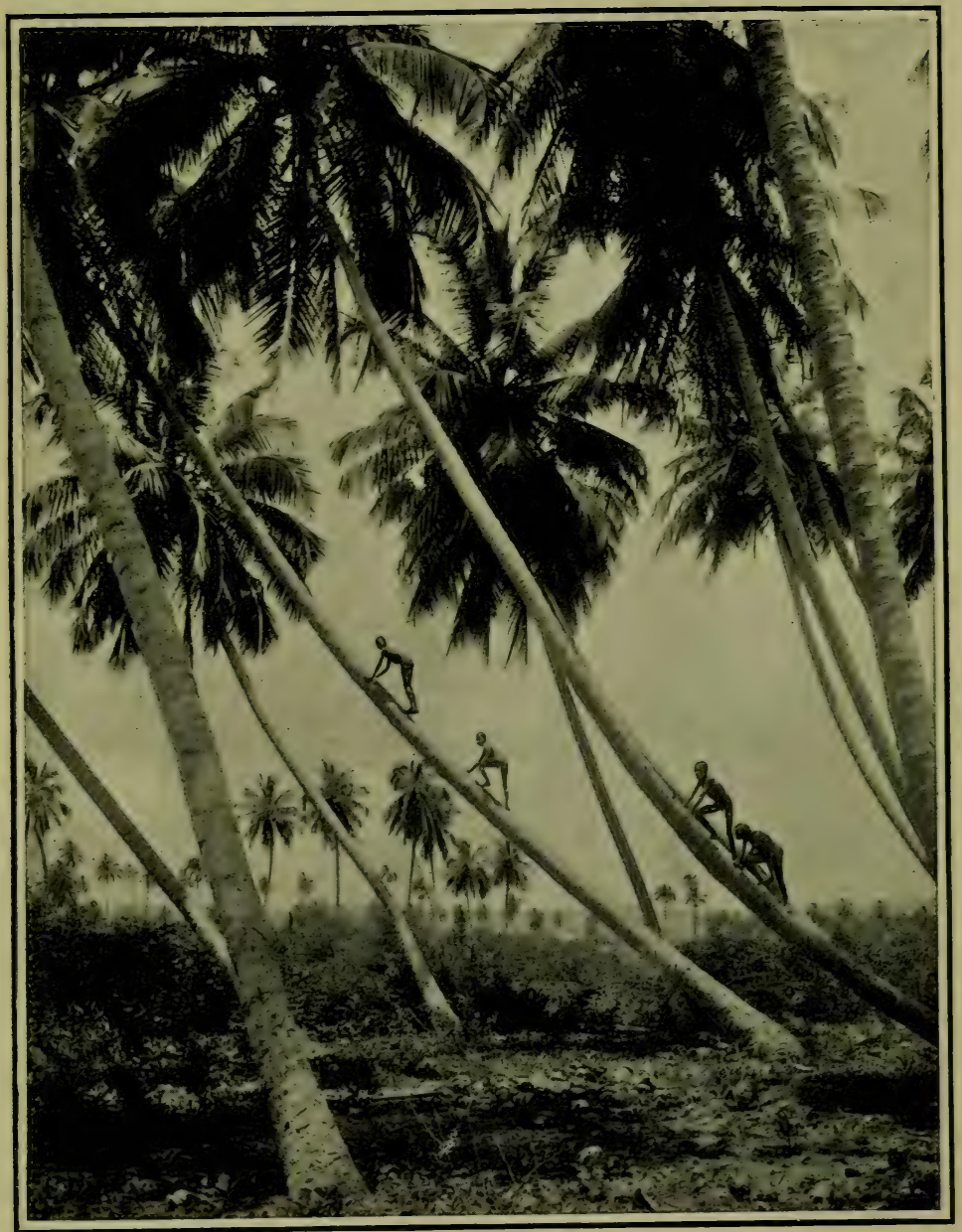

Stereo Copyright, Underwood \& $U$.

[Lonton and Nezu York

Cocoanut Palms near Aquadilla (Porto Rico)

The curious inclination of the trees is probably the effect of storms. 



\section{Fortunate Islands}

satisfying and also yields an enormous harvest. Some doubt has been cast recently on the stories which one used to believe as to the amount of sago to be obtained from the various sago palms. But even if they required ten years to be mature, it is the actual trunk of a tree which is packed with this valuable food material.

Yet from all these fortunate islands, Canaries, Madeira, Azores, Bahamas, Bermudas, and the South Sea Islands, it is difficult to call to mind either a race or an individual who has left any permanent impression on the world's history.

The softness of the life and the easiness of living seems to enfeeble and deteriorate every race which occupies them.

But the flora of such islands is full of interest. Species continue to live in them which have died out in the stress of continental competition. Being clearly limited and of convenient size, they often show very distinctly the dependence of plants on special climates. They are also interesting from the problems which depend upon how they were first colonised.

When one first visits Teneriffe one cannot help remembering the classical description of Von Humboldt, and the neat limiting of its various floras according to the height above the sea.

The zone of cultivation up to I 500 feet, the laurel woods from I 500 to 5000 feet, the forest of pine from 5000 to 8000 feet, and then the alpine plants to 9800 . This is so very like a blackboard diagram and, what is perhaps not so often realised in these days, it is still, with certain modifications, quite a true picture of the vegetation.

The lower ground has been much altered by cultivation and by grazing, but in the rugged barrancos one may still discover magnificent Sempervivums, those odd fleshy candelabra-like Euphorbias, and many other char- 


\section{Fortunate Islands}

acteristic rock and dry climate plants not found elsewhere.

At those heights from I 500 feet (or on the S.W. and S.E. 2500 feet) to 5000 (or 4000 on S.W. and S.E. sides), where the clouds are still in the habit of resting so as to keep fresh and moist the gathering grounds of the springs which irrigate the lowlands, the changes have been very great. This is the home of Laurus canariensis, of Olives, Rhamnus, Arbutus, Myrica faya and Viburnum.

It is a strange flora which recalls, perhaps better than any other still living, the old Miocene times of Europe before the Ice Age disturbed everything. This part has unfortunately been much altered by the grazing of animals and much of it is now covered by those gum-cistus heaths which are prevalent in Spain and Portugal. The coniferous forest (Pinus canariensis) is also much destroyed and almost obliterated, yet from 5400 to 7800 feet occasional pines exist along with bracken, thyme, helianthemums, and the common asphodel. Above this level, where the influence of the cloud is rarely felt, there comes a dry and sunny mountain-desert where Spartium nubigenum, Cytisus proliferus, Arabis albida and Ephedra may ascend to $985^{\circ}$ feet. $^{1}$ The last flowering plant is the little violet discovered by Von Humbolt.

This, the highest part of Teneriffe, resembles the cold dry deserts at great altitudes in Tibet and in Peru.

The general suitableness of all these various floras to their positions on the mountain side is a typical and most instructive example of Nature's workings.

The way in which the South Sea Islands obtained their rich and varied floras is always interesting but by no means fully understood.

It is not always remembered that two things are necessary when a desert island has to be colonised. The 


\section{Fortunate Islands}

seeds must reach it, but they must also be able to grow upon its special soil.

When Dr. Schimper visited a lava-flow (eruption of r 843) in Western Java, he found that there were no trees upon it. ${ }^{2}$ The surface had been no doubt inhabited first by the blue-green algæ (p. 20), and then by ferns which were still numerous enough. But though the rich tropical forest was in full vigorous development beyond the lavas, the only plants which had managed to settle upon its surface were orchids and other Epiphytes such as occurred elsewhere on the branches of the forest-trees, as well as a peculiar rhododendron, an insect-devouring Nepenthes, and others which belonged to dry or rocky habitats.

All of them were adapted to obtain their nitrates and other food not so much from the soil as from the atmosphere or from peaty material.

Mr. Ridley has shown that when a bare tree branch in a tropical jungle is colonised by Epiphytes, the process is not unlike that which happened on Krakatoa. First blue algæ establish themselves, then it is overgrown by mosses and ferns, and then the orchids and other flowering plants plant themselves upon it. ${ }^{3}$

The seeds of these orchids are exceedingly minute, and remind one of the dust-like spores of algæ, mosses, and ferns; they are easily blown by the wind or carried by birds from branch to branch, or to desolate lava-flows, and even to lonely islands far out to sea. The stalks of these orchids generally hang down, or droop over the branches, so that the flowers are quite conspicuous, but when in fruit the stalk is erect, so that the tiny seeds are shaken out of the capsules by any violent wind.

On these lonely islands of the Pacific, then, one would expect a large percentage of the plants to possess small 


\section{Fortunate Islands}

light seeds which could be easily carried by the wind, and this is found to be actually the case.

One might suppose also that those trees which have aeroplane seeds or fruits would also be found on them, but this has been questioned. One of the neatest contrivances of this kind is found in Shorea, a tree of the Malayan peninsula. According to Mr. Ridley, however, the fruit cannot fly for more than forty yards. As the tree cannot produce fruits until it is at least thirty years old, he calculates that it would take 58,666 years to travel a hundred miles, and must have required about I,500,000 years to get to the Philippines from its present home in Malaya.

One feels a little doubtful as to whether a hurricane or typhoon might not be trusted to do better than merely carry a winged fruit for forty yards, but the proportion of aeroplane fruits and seeds in island floras is not large. Birds, however, assist in carrying fleshy, sticky, and spiny fruits from island to island, and especially those which have hard and indigestible seeds. They have wonderful capacities in the way of swallowing, as can be seen even in Britain by watching a woodpigeon when dealing with an acorn, and the beautiful South Sea pigeons have probably been of great help in supplying islands with new plants. Migrating birds are said to travel enormous distances.

A curlew may possibly leave a Scotch moor and eventually arrive at Kimberley in South Africa. ${ }^{4}$ The little arctic bluethroat is said to go from Heligoland to Morocco in a single flight without resting anywhere $\mathrm{en}$ route. Surely, however, the bird would take the simple obvious precaution of clearing its plumage of all mud and sticky or spiny fruits before starting on a voyage of this kind?

But it is the navigator plants of the South Seas that 278 


\section{Fortunate Islands}

have been most carefully studied, and indeed their story is a romance in itself.

There are from 80 to $\mathrm{I} 20$ of these navigators belonging to the most various orders, but all are well able to take a long sea yoyage.

Their seeds or fruits are able to float for a very long time without being in any way injured. Cæsalpinia, for instance, has been allowed to float for two and a half years in salt-water, and many others have survived for a year and have germinated successfully afterwards.

Cæsalpinia bonducella has been carried from across the Atlantic to the Orkneys, Ireland, Hebrides, and Scandinavia, and also to St. Helena. Robert Brown succeeded in growing a plant from one of these American-Irish seeds.

Perhaps another of them (Entada scandens) is an even more efficient navigator, for it has been found in the Azores and in Nova Zembla, as well as in all the places just mentioned. Seeds from the Azores germinated at Kew. ${ }^{5}$

These two are Leguminosæ and are able to float in consequence of their hard, woody, and hollow pod, which is in fact very like two shallow wide punts joined together along their sides and enclosing the seed in an air-tight compartment.

Most of the navigators have porous or buoyant tissue somewhere in the fruit or seed due to air cavities or hollows.

Now waterside plants and especially submerged plants are always remarkable for the number of air channels or intercellular spaces. Such cavities are almost always to be found in water plants, and are due to the special necessity of preserving oxygen when submerged or growing in mud. So these navigator plants again show a strange example of fitting reaction. This 


\section{Fortunate Islands}

tissue, the result of a water life, has been utilised and developed to serve a totally different purpose, that of floating and so voyaging to distant islands.

There are two groups of these navigators. One set consists of the mangroves and their attendant satellites. These are specially adapted to colonise muddy estuaries (see p.325). The rest are the ordinary coral strand plants.

Dr. Guppy found by actual experiments that the seeds of 95 per cent. of the eighty navigators were able to float; 75 per cent. of them were kept in the water for two months, and showed no sign of losing buoyancy. For comparison he collected a hundred seeds of inland plants in one of these South Sea islands and found that 75 per cent. of them sank immediately.

The history of the colonisation of the Pacific Islands is still obscure, but the general course of it has been traced from Indo-Malaya to the eastward. As one proceeds east, the number of these navigator plants becomes gradually less. Tahiti, for instance, only possesses fifty-five out of the eighty species recognised as characteristic, and it is only cosmopolitan species that have managed to reach the American coast-line.

But the unfortunate point is that the ocean currents in the Pacific do not flow from west to east; indeed, the north and south equatorial currents are exactly opposite to the apparent direction in which these plants have travelled.

There are currents by which the navigators could travel without difficulty from the Malay peninsula as far as the Philippine Islands and even to New Caledonia, but from this point to Tahiti they have managed to travel against the regular drift, which is from east to west.*

* Dr. Guppy suggests that during the north-west monsoon, that is, from January to March, some might have reached the Solomon Islands and others by the Caroline, Marshall, and Ellice groups. There is also the counter current (west to east), which might have been utilised by some of them. 


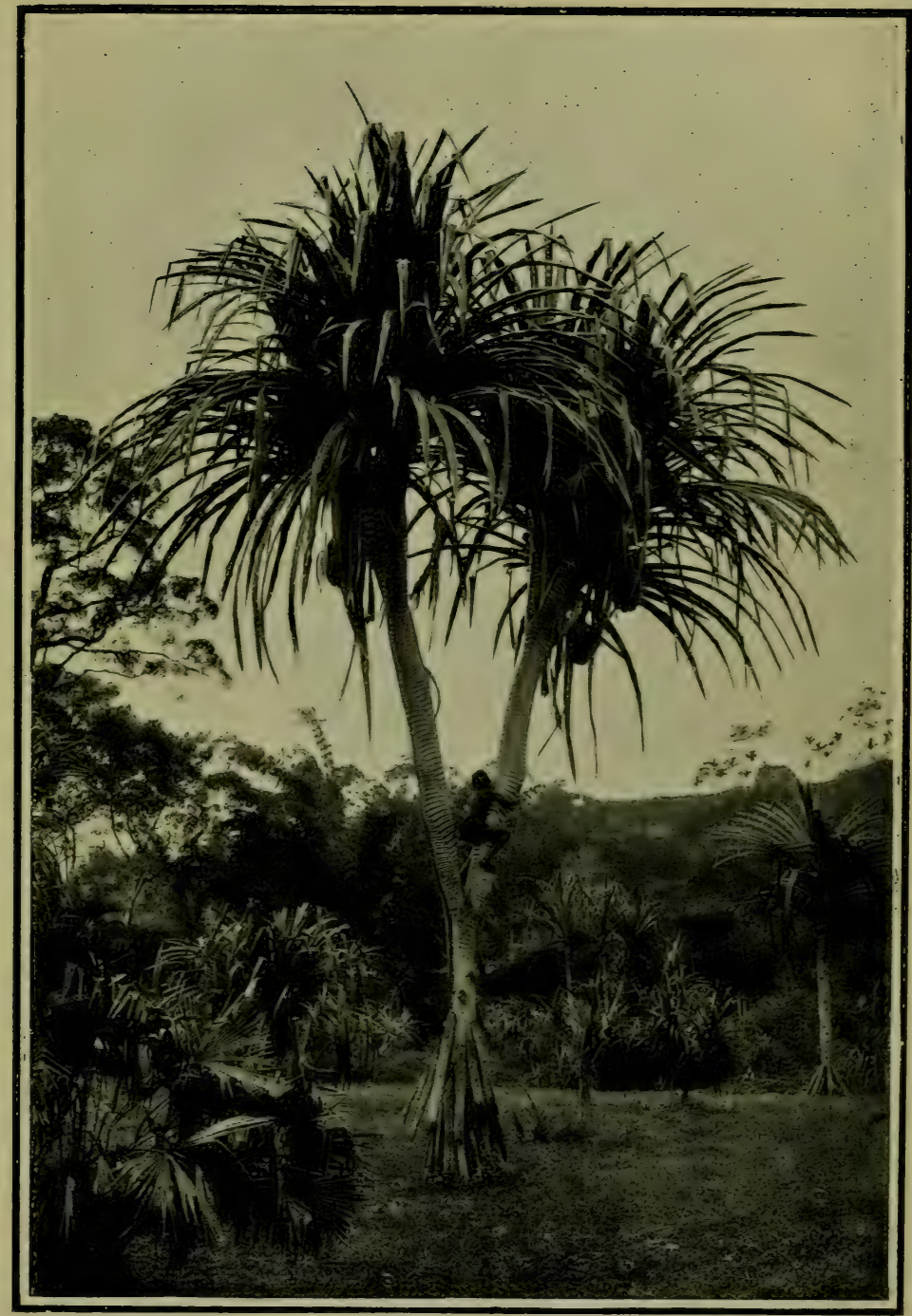

Photographed by]

[Skeen \& Co., Ceylon

Screw Pine or Nicobar Islands Breadfruit (Pandanus lusani)

Showing the method of gathering the fruits. 



\section{Fortunate Islands}

Suppose one of these navigator seeds has stranded on the coast of a desert island, then it has still various difficulties to meet with. If it is a mangrove seedling, it will only be able to take root and grow if it has happened on a muddy foreshore. It will perhaps germinate, but is sure to die if the coast is sandy or coralline. The usual associates of the mangroves can only establish themselves if there is at least the beginning of a mangrove swamp. There are, for instance, none of the mangrove association in Tahiti, because apparently there is no place suitable for them.

But if the newly arrived navigator plant is an ordinary coral strand plant, it will at once take root and begin to grow vigorously. Sometimes they are destroyed by crabs, which nibble off the young shoots, but this seems not to be a common casualty.

One can see this happening with such a common navigator as Entada which, once established on the shore of an island, soon spreads itself all along the coast, and may even pass inland and be found straggling over the trees and bushes at a long distance from the shore.

It has apparently happened that the descendants of some of these navigators have not only taken to an inland life, but have become so modified and changed as to constitute entirely new and peculiar species only found in one of these island groups. This seems to explain at least the various island species of Vigna, Premna, Canavalia, Erythrina, Sophora, and Ochrosia, for each of these genera has a navigating species.

But one cannot entirely account for all the plants in South Sea islands by these explanations. Many are neither navigators nor descendants of them, nor are their seeds, so far as we know, carried either by wind or by birds. 


\section{Fortunate Islands}

The most puzzling of all are the archaic and oldfashioned conifers, which are dotted about in the most remarkable way, as shown below.

\begin{tabular}{|c|c|c|c|c|c|c|c|}
\hline & $\begin{array}{l}\text { South } \\
\text { America. }\end{array}$ & Malaya. & $\begin{array}{c}\text { East } \\
\text { Austra- } \\
\text { lia. }\end{array}$ & $\begin{array}{l}\text { New } \\
\text { Cale. } \\
\text { donia. }\end{array}$ & $\begin{array}{l}\text { New } \\
\text { Zea- } \\
\text { land. }\end{array}$ & Fiji. & Hebrides. \\
\hline Aratucaria . & $x$ & - & - & $x$ & - & - & $x$ \\
\hline $\begin{array}{l}\text { Dammara, Aga- } \\
\text { this }\end{array}$ & - & - & $x$ & $x$ & $x$ & $x$ & $x$ \\
\hline Podocarpus & $x$ & $x$ & $x$ & - & $x$ & $x$ & - \\
\hline Dacrydium & $x$ & $x$ & - & $x$ & $x$ & $x$ & - \\
\hline
\end{tabular}

Here again one finds the three competing theories (see Chap. IX., The Antarctic): (I) Those who have got into the habit of evoking continents will assume some ancient antarctic continent linking up all these isolated spots. (2) They may all be survivals of a very ancient flora, which probably travelled from somewhere in Asia or Europe. These places might all be described as Land's Ends, and the last to be invaded by newer kinds of plants. (3) Various ordinary and extraordinary methods of carrying fruits and seeds might account for them. Winds, birds, drifted timber, and possibly icebergs might be responsible for this confusing and remarkable distribution.

Belonging as they do to a very ancient type of plant, they would have had many more chances of spreading themselves abroad than plants of a more modern type.

But then one finds exactly the same difficulty in another interesting series which are by no means so ancient.

In the cloudy solitudes of Mount Ruwenzori, in the very centre of tropical Africa, and above the bamboo zone and tree vegetation, the author found certain very remarkable Lobelias. Their flowers were enormous, and they were shrubs with large leaves and altogether of a most impressive character. 


\section{Fortunate Islands}

Again in Chile, in the bush above Concepcion, there was the handsome but poisonous Lobelia (Tupa) called the Devil's Tobacco. These remarkable plants form a special group which occur in Abyssinia, Fernando Po, Kilimanjaro in Africa, in South America; there are a few in Tahiti, and also some sixty species of them in Hawaii of all places in the world. One of these is said to be sometimes 40 feet in height.

Are these also ancient relicts of some older worldvegetation driven to the mountains in Africa, having by a lucky chance succeeded in taking refuge in Tahiti, and still withstanding competition in South America?

But this is enough to show how puzzling and how varied are the interesting problems still left unsolved in the South Seas and other Fortunate Islands.

1 Webbe.

4 Maxwell.
2 Schimper.

5 Guppy, Schimper, Tansley.

3 Ridley. 


\section{CHAPTER XXV}

\section{PRACTICE OF PLANT BREEDING}

IT is a very difficult matter to define the just and exact relations of theory and practice.

In theory, theory should lead just as the horse should always come before the cart, but in practice this seems to be most unusual.

There are three distinct and separate principles by which breeders of plants endeavour to improve their special races and strains. The first and most obvious course is to select the very best individual plants for seed, and to breed entirely from them. The second method is that of crossing or hybridising different races or strains, and selecting some of the mongrels for further trials. The third consists in varying or altering the conditions under which the plants are grown, with the object of tempting them to produce something unusual or odd, and which may be of use. Sometimes these three methods are combined. Indeed a great many well-known breeders habitually use the first and second principles. The third is at present rather unfashionable, but has nevertheless produced important results.

For the sake of clearness and common-sense, we shall try to explain first some of the triumphs obtained simply by selection of the best varieties. It was by this method that Le Couteur of Jersey and Patrick Shirreff of Haddington so greatly improved our corn and wheat crops. The latter produced the celebrated Hopetown oats in 1832 , and during forty years of work was able to place on the market four distinct varieties, all of which were very valuable to his generation. Other 284 


\section{Practice of Plant Breeding}

famous examples of the same sort were Rimpau's selected varieties of the rye, which have recently not only displaced all others amongst his German neighbours at Schlanstedt, but have invaded France and beaten out of the field many of the older French races. ${ }^{1}$

But even by selection of the best plant in a large field of corn, one cannot produce the very best results. It is necessary to select the best grain of corn in the best ear. This was first done by Hallett of Brighton many years ago. He chose the best kernel of the best ear of wheat.

The plant which sprang from it had 47 grains in one particular ear. Again choosing the best kernel, he got 79 grains in the second year, and in the third year no less than 90 grains. His strains were a very great success, and enormously improved the British harvests of his time. Exactly the same method has been found advantageous by Dr. Nilsson of Svalöf in Sweden.

At the Ontario Agricultural College, Professor Zavitz has had some remarkable triumphs by using this system.

One selected grain (the very best amongst ten thousand) of black Jannette oats, sown in 1903 , produced in I 905 over Ioo bushels of grain and no less than 8748 pounds of straw. ${ }^{2}$

The following table shows the results from various sized seeds :-

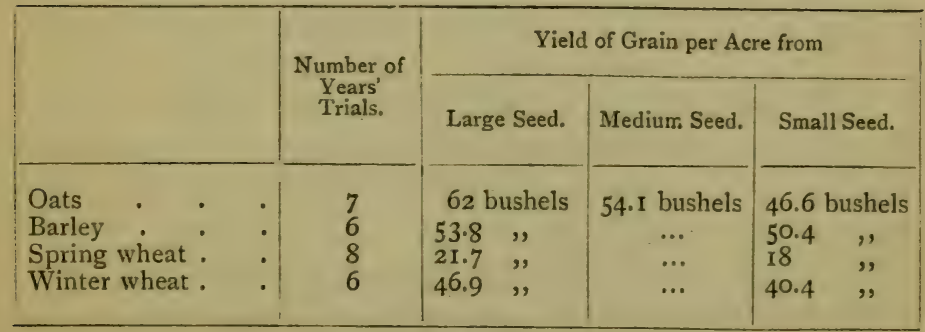




\section{Practice of Plant Breeding}

Amongst others who have found the selection of the largest seeds to be an undoubted advantage are Arthur ${ }^{3}$ (with peas), and Liebscher and Van Seelhorst. ${ }^{4}$

The heaviest seeds are not only most productive but are also, sometimes at least, the most vigorous and most enduring. ${ }^{5}$ Just the same result has been discovered in practical forestry. The finest and largest seeds produced the strongest and most vigorous trees, ${ }^{6}$ so that the importance of this very simple principle is therefore manifest enough.

Other experiments have shown that very large and heavy potatoes produce descendants which inherit those valuable characters. That was the result obtained by Van Seelhorst between 1898 and 1903 .

There was a short time ago a crisis in the history of Sea Island cotton in the United States. Some mysterious disease suddenly increased and destroyed whole fields of cotton. Some of the very best land seemed to be hopelessly affected, and it looked as if the whole industry would be destroyed.

A minute fungus which infested the soil was the author of this trouble. Mr. W. A. Orton was sent down to the cotton-fields to try and deal with the situation. $\mathrm{He}$ discovered here and there some individual stalwart cotton plant which bore fruit in spite of the Fusarium fungus. From their descendants he established a race of Sea Island cotton which defied its attacks. ${ }^{7}$

Disease-proof pine-apples have also been obtained and quite in the same way. ${ }^{8}$

Other valuable plants obtained in this simple manner are the thornless oranges, violets with an enormous number of flowers, and beetroots and sugar-canes with a very high percentage of sugar contents. ${ }^{9}$

The most remarkable of all known cases of selection is perhaps that of the seven-leaved clover. The cele- 


\section{Practice of Plant Breeding}

brated botanist, De Vries, found a plant of clover in which some of the leaves had four and five leaflets. By selecting from these clover plants he obtained races in which four and five leaflets were the usual character. But some of the leaves had six and seven leaflets. It is very unlikely that any clover plant in the world ever had seven leaflets until De Vries started those experiments.

The second method, that of hybridising, has been also found extremely useful in practice.

Natural hybrids are common enough, and especially amongst willows, brambles, and mints. (Long lists of natural hybrids will be found in the "Report of the Conference on Genetics," published by the Royal Horticultural Society in I906.)

But they do not seem able to survive under natural conditions. Mentha sativa is said to be a cross between M. arvensis and M. aquatica, but it cannot hold its own in competition with its parent species. ${ }^{10}$

All sorts of experiments have been carried out in hybridisation.

One of the most unexpected has been the production of odd and strange ferns. ${ }^{11}$ The spores of many kinds of ferns are all sown together on damp soil. So soon as the prothallia are in good healthy development, the place is flooded with tepid water for a few minutes. Some of the antherozoids (male cells) succeed in reaching the egg cell of some other kind of fern, and a weird but valuable mongrel may be the result.

In Florida a severe winter may destroy the ordinary Mediterranean oranges, but by crossing the valuable races with Citrus trifoliata, which is able to resist cold, the citranges "Willits" and "Rusks" have been produced, and these are found to be of great value. ${ }^{12}$

Amongst other triumphs in this line of research are 


\section{Practice of Plant Breeding}

disease-proof melons and wheats which withstand rust fungi. ${ }^{13}$

Mr. Biffen has long been engaged in trying to produce a "strong" (in the baker's sense) wheat which will also have the enormous yield of our ordinary English wheats. The barleys, wheats, and oats of Messrs. Garton are also apparently hybrids.

But it is in crossing orchids that the most remarkable results have been obtained.

These orchid-hybrids are sometimes entirely new and quite different from either parent. The flowers are not infrequently larger and show magnificent colours and strange combinations of characters.

Hybrids are often more vigorous and luxuriant than their parents, but it is not always the case that the descendants of these hybrids inherit those characters. The various species of Odontoglossum and other orchids hybridise very freely and even in nature, without any assistance. This was well seen in the exquisite series of Odontoglossum hybrids shown by Mr. Rolfe at the Darwin-Wallace celebration of the Linnean Society in I908. Even those who hybridise most, almost invariably select carefully as well, and it is by a combination of both methods that the most striking results are obtained.

It is necessary, of course, to speak of Luther Burbank, whose creations have been very freely described in books and gardening papers. He had the advantage of being born near Boston in America, but his father was English and his mother Scotch, which is also always an advantage.

As a baby (he was born in I 849 ) he used to hold flowers in his cradle, and when able to walk preferred plants such as a "lobster cactus" to kittens and dogs for his pets. All through his life he continued to study 288 


\section{Practice of Plant Breeding}

and to love every kind of plant and of flower, but especially cactus'.*

He migrated to California, where for many years he had a very hard struggle. Then he obtained an order for 20,000 young prune trees to be supplied within nine months.

To raise a prune tree from seed requires at least two and a half years. But Burbank planted almondseeds which, in that stimulating atmosphere, grow very rapidly, and budded 20,000 prune buds on to them as soon as they were large enough. To-day those 20,000 prunes are said to form one of the finest orchards in California.

The system upon which he seems to work does not apparently differ from those employed by others in any essential character, but his selections and his crossings are done upon a scale unprecedented in its magnitude.

At the end of certain experiments he burnt in one of his bonfires no less than 65,000 two- and three-year-old berry bushes. His plums are grown by the mile, and his grafts and hybrids are made by the thousand.

Then also he has an experience which is unrivalled, and a skill which can tell from the foliage of a plum whether its fruit will be worth keeping or not. The climate which he has selected is probably the best in the world, and land must be extraordinarily cheap.

These advantages are possessed surely by no other plant-breeder. Moreover, he does not himself distribute and sell his creations. They are sold as soon as produced to various American firms, whose skill and experience in advertisement admit of no dispute.

In this country we would very much like to obtain some at least of those creations of his. There is his

* See Harwood, "New Creations in Plant Life," and De Vries, "Plantbreeding," for these and other details. 


\section{Practice of Plant Breeding}

hybrid walnut, for instance, planted in I89I and said to have been 80 feet in height and 2 feet in diameter in I906. The timber is also said to be of excellent quality. Such trees would solve all our forestry problems. His stoneless plums, obtained from an old and useless French variety, would also be valuable, and so with many of the others.

In forming his Alhambra plum he is said to have combined seven different varieties, which were grafted on old trees and so brought into bearing at the earliest possible moment.

One can only hope that the spineless edible cactus with which he experimented for many years, and for which he crossed many different American species, will really prove hardy and useful in desert and half-clesert places.

During 1906, in the first six months of their life, some of these cacti produced $47 \frac{1}{2} \mathrm{lbs}$. per plant which, as they were planted in rows 5 feet apart and $2 \frac{1}{2}$ feet distant, has been estimated as a yield of 90 tons per acre. Even if this should prove unsuited for cattlefeeding, it will surely be of value, perhaps, for the production of alcohol. It is unnecessary to describe in detail the Shasta daisies, the Cannas 7 inches across, and the huge Amaryllis and other flowering plants which have been produced by him.

In breeding lilies he is said to have used 500,000 plants in one single test.*

$\mathrm{He}$ was not, however, always successful. In his efforts to improve the Californian dewberry, he crossed it with brambles, with rasps, strawberries, roses, cherries, apples, and pears and never got any satisfactory result. Hundreds of Nicotianas were crossed with Petunia, but

* This account of Luther Burbank's life and work is entirely derived from books and publications. The author has never seen any of his novelties. 


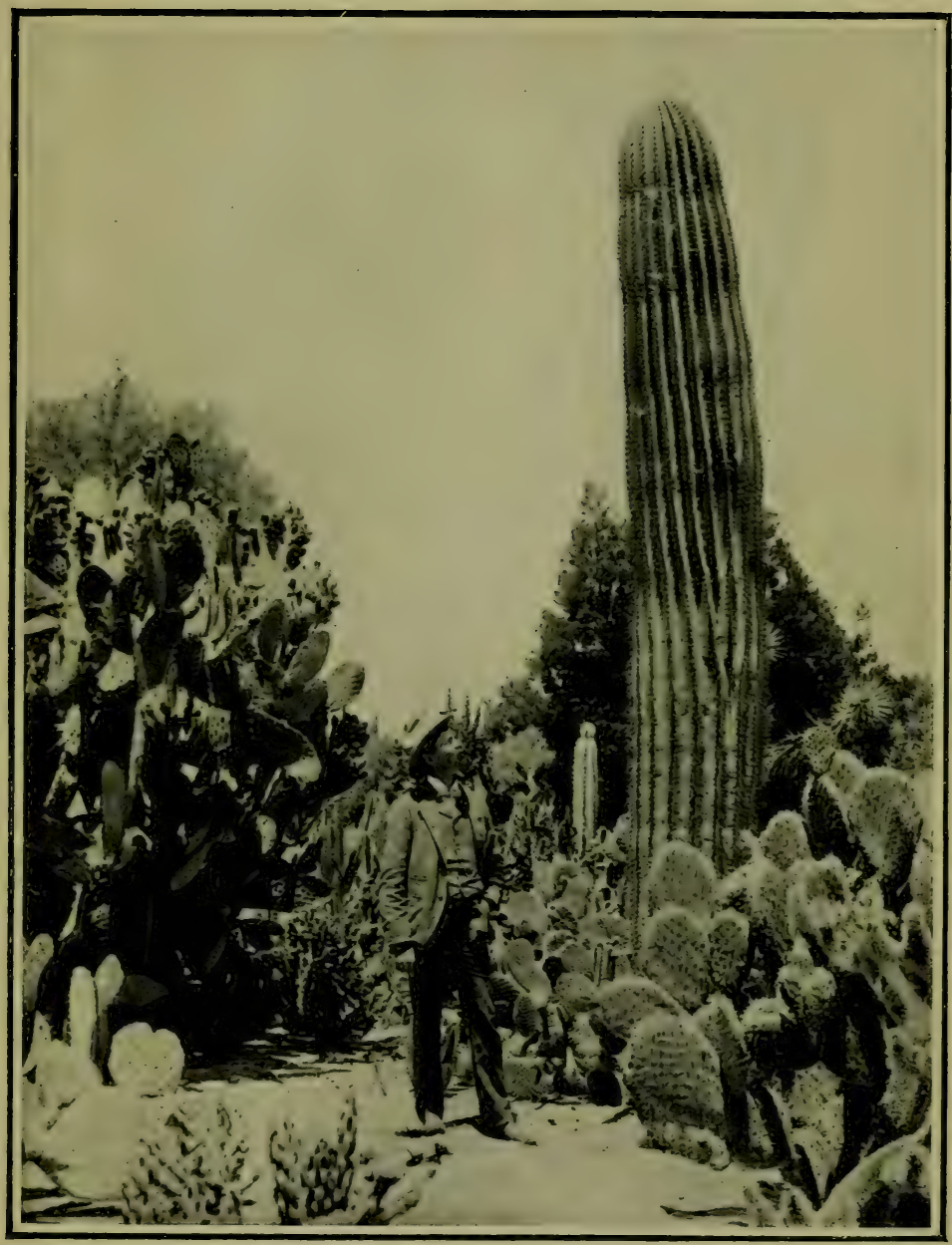

Stereo Copyright, Unaerzood o U.J

[London and New York

A Giant Cactus at Riverside, California

The prickly pears (opuntia) and other succulent plants have all been planted. 



\section{Practice of Plant Breeding}

only one seed germinated. The plant was an annual and never set any seed!

The third method, that of altering the conditions in which a plant lives in order to induce it to change or vary, is also, by report, used by Burbank. It is possible that many plant-breeders possess their own secrets as to culture and treatment. Both Patrick Shirreff and Hallett did endeavour to assist the plant in its efforts to produce better seeds by specially kind cultivation.

Unfortunately the cold shadow of Weissmannism still discourages experiment in this direction (see below).

But that plants can inherit the method of growth, \&c., induced by special conditions is quite certain.

At great altitudes in the Alps, trees grow very slowly and shed their leaves at a much earlier date than those at lower and more genial elevations. Some interesting experiments by Engler and Cieslar have proved that these habits can be inherited.

Seeds of spruce, larch, sycamore, \&c., were collected at various altitudes in the Alps and in Austria. Experimental gardens were then formed at various places, also differing in altitude, and the different rates and habits of growth were carefully observed and recorded.

At Adlisberg (2200 feet) it was found that five-yearold spruces grown from Engadine (5950 feet) seed were on an average 9 inches, whilst others from Winterthur seed (I 800 feet) were 18 inches in height. So that those whose parents lived at very great altitudes grew at just half the rate of the others. The other characteristics of their high Alpine parents, such as a very extensive root system and a tendency to branch from the base, were also quite distinct.

Fifteen-year-old trees from Carinthia gave quite similar results. One set (seed from I 700 feet) were 4 feet 5 inches high and grew 4.2 inches in 1905 , and 


\section{Practice of Plant Breeding}

another set (seed from 5200 feet) were only 30 inches high and grew 2.4 inches in the same year.

At Adlisberg also larch-seedlings (seed from Avers 6300 feet, and Engadine 6900 feet) were only 9 and I 5 inches high respectively. These young trees stopped growing on June $27^{\text {th }}$ and July 2 nd.

As a control experiment, larches of the same age from Bonaduz seed (2350 feet) were 26 inches high, and went on growing till August i 8 th.

Sycamores (three-year-old) from Alp Drusen seed lost all their leaves on October $13^{\text {th }}$ and were not more than 16 inches, whereas others from Adlisberg seed were 25 inches in height and remained in leaf until November I 2 th.

Such instances as these quite conclusively prove the inheritance of such habits as slow growth, time of growing, and of leaf-fall. Those parent larches which grew at 6000 feet and over had surely acquired the habit of slow growth simply because there was too short a season to grow fast. And as we have seen, this habit was transmitted, somehow, to their seedlings.

The parent sycamores on Alp Drusen would certainly have had their leaves killed off by frost, \&c., in the middle of October, and had transmitted the habit of shedding their leaves at that date to their descendants, who had never known a severe Alpine climate. Perhaps even more interesting are those experiments of Klebs, who was able by varying the conditions of growth to change the colour of Campanula trachelium from blue to white, and again by another change from white to blue. ${ }^{14}$

Both blue and white varieties not only of Campanulas but of all sorts of flowers regularly inherit the colour of their parents when cultivated under the same conditions.

So that this third method, that of varying the conditions of cultivation, is quite as promising as either selec- 


\section{Practice of Plant Breeding}

tion or hybridising, although it is perhaps infinitely more difficult. Some results are very unexpected.

Muller (Thurgau) selected ten potatoes of, as nearly as possible, exactly equal size. Five were kept in an ice-house and the others in a house cellar at ordinary temperature. Both were planted at the same time, but those from the ice-house gave a large crop three months after planting, when those which had been kept warm had only begun to sprout!

One unfortunate point about all man's selected and improved varieties is that they are apparently doomed sooner or later either to degenerate and fall back into their original state, or to become so feeble in constitution that they readily fall a prey to fungus-diseases or insect-attacks.

Some practical plant-breeders doubt whether this must necessarily happen. There is a long discussion of the subject in the Journal of the Royal Horticultural Society for December I906, especially with regard to potatodegeneration. Some excellent sorts, such as Victoria, degenerate quickly, and others (Dunbar Regent) have vanished, although they were heavy croppers and of an excellent quality. The best types of 1845 , such as Buffs and Dons, are no longer to be found.

There are, it is true, apparent exceptions, such as Ashleaf and Early Rose, which seem to have perennial youth; but these are early varieties, which would probably escape the worst attacks of the fungus in any case.

Of course when a plant is propagated continually by tubers, it is just the same individual plant that goes on living from year to year, and one would expect it to grow old and feeble. But 500 years is not a very great age for some trees, which may live to 3000 years or more under exceptional conditions. No variety of 


\section{Practice of Plant Breeding}

potato is even Ioo years old, but there is still the probability that they do begin to grow aged and enfeebled, so that new varieties raised from seed will be required to replace them.

It is usual in England to get seed tubers from Scotland; even in Scotland some growers obtain their seed from high, cold, and late districts. Such seed potatoes are supposed to be more hardy than those raised in England.

It is possible that the "Fife" wheat which comes from Canada owes some of its splendid qualities to the severe climate conditions under which it originated. The history of this variety is very remarkable; a Scotchman (David Fife, in Ontario, Canada) obtained some Dantzig wheat from Glasgow. Only three ears, the produce of a single grain, ripened, but the splendid Canadian harvest of 1908 ( I I,375,000 quarters) seems to be almost wholly descended from that one seed. Not only so, but it is this same Fife wheat which is relied upon to save the situation in England.

It is thought that the Fife wheat is not a Dantzig race, but due to a grain or two of Galician wheat which had got in by accident. ${ }^{15}$
1 De Vries.
2 Zavitz.
4 Liebscher and Van Seelhorst.
7 Erwin Smith.
10 Malinvaud.
5 Jones.
8 Buttenshaw.
3 Arthur.
13 Salmon, Biffen
11 Druery.
14 Klebs.
6 Engler, Cieslar.
9 Morris.
12 Erwin Smith.
15 Humphries. 


\section{CHAPTER XXVI}

\section{THEORY OF PLANT BREEDING}

THE practical breeder of plants proceeds doggedly with his experiments, yearly launching on the world new and, it is to be hoped, distinctly lucrative varieties.

All the time there is surging around him furious controversies which are shattering and overwhelming the very basic principles upon which the whole of his work depends. Now it is a high tide of Weissmannism, then a raging sea of Mendelism, which is followed by foaming waves of the theory of Mutants, and so on indefinitely.

He knows nothing of these angry storms, and would not very much care about any of those proofs and deductions and denials which so abundantly distinguish every new point of view.

It is of course abundantly clear from every breeder's experience that acquired characters are in some way or other inherited. One has only to refer to those Alpine larches (see p. 29I), to Klebs' experiments (p. 292), and to all ordinary gardening experience.

Desert plants are adapted in almost every one of their characters to the necessities of the desert. It is an extremely difficult matter to grow them in an ordinary British garden. But if a very skilled gardener can manage to raise a few out of many seeds, the results are very interesting. They retain some of the desert characteristics, but in a modified way. They are neither so hairy nor so woody, but yet show quite well the struggle which is going on between heredity and environment. They are trying to adapt themselves to the new conditions, but retain many desert characters. 


\section{Theory of Plant Breeding}

In nature there can be but very seldom so sudden and complete a change of climate as that between the Sahara and an English garden. As Dr. Wallace points out in the most recent of his addresses* (so far as the author is aware), there seems to have been but little change in the European flora since the Glacial Period profoundly altered and disturbed all the climates and conditions of tertiary Europe.

As a rule plants inherit not only ancestral habits and structures, but also the climate of their ancestors. Their harmony with the environment is of a general businesslike character; it is not, in most cases, exact and mathematical.

Such genera as the hawk-weeds, brambles, roses, Euphrasia, and several others seem to those who have specialised on them to consist of an enormous number of little species, very difficult to define or to separate, but nevertheless distinct. These might be considered as tentative attempts at a new species, of which a single one might manage not only to survive but to kill out all the others if it was in every way distinctly the best.

What, however, produces these changes which distinguish the little species from one another?

It is upon this point that there is so much uncertainty. Lamarck and especially the Neo-Lamarckians believe that any change in the environment must necessarily affect not one but all the plants which are subjected to the change.

On a particularly dry and sandy knoll where the soil is poor, every plant will be affected by the conditions and all will become dwarf and stunted.

But if this change of climate is marked, and especially if it is continued for generations, the effect is not only external but the whole internal condition of the plant

* Phamacentical Joumal, rgog. 


\section{Theory of Plant Breeding}

may be altered. New enzymes or other chemical substances will be formed, and others may be destroyed. If in a desert plant, more material is used up in thickening the epidermis-walls of the leaves, then there is less available for other purposes.

If strong and vivid flower-colours are produced in the clear atmosphere, and strong sunshine of an Alpine meadow, then something different must be going on in the wonderful chemical laboratory which we call a flower-petal.

Changes of this kind must surely influence the delicate balance of supply and demand in the life of the plant, and the proportions and nature of its various ferments and enzymes.

It is not necessary to call in any complex theory of pangenesis for the inheritance of these ferments, for enzymes or whatever goes to produce them are most certainly inherited.

Remembering this delicate balance in the physiological life of a plant, the old views as to the importance of changes in the outside world or environment become much less difficult to maintain. Nor is it so impossible to believe in the inheritance of the effects of use and disuse.

There are such cases as the evolution of the American trotting horse. In 18 I 8 the record speed was I mile in 3 minutes. In 1824 it was reduced to 2 minutes 34 seconds, in 1848 to 2 minutes 30 seconds, and so on until in 1896 it was 2 minutes ro seconds. ${ }^{1}$

The rigorous selection of these animals for one quite useless and artificial accomplishment is not at all more severe than the usual struggle for life amongst seedlings.

But that the continual practice of all the ancestry since 18 I 8 has had no effect whatever in cutting down the record seems a thoroughly artificial and unnatural supposition. 


\section{Theory of Plant Breeding}

Weissmann's followers do explain such cases by assuming that these practisings and trainings affect the germ-cells and so may alter the organism. But amongst botanists there has been, from the first, much scepticism about germ-plasmas. Such cases as the following are very difficult to explain if there is any truth in Weissmann's theory.*

When leaves of begonia are cut off and placed in soil, they take root and may form new plants which flower and fruit.

There are no germ-cells in those leaves, only ordinary protoplasm, so that, as Professor Henslow pointed out (early in the controversy), there is no use in botany for a theory of germ-plasmas as distinguished from ordinary protoplasm, which indeed is quite mysterious and complex enough for all theoretical purposes.

The theory of mutation, which owes its origin to De Vries, is still the subject of an active and vigorous controversy in the botany of to-day.

It is based on the peculiarities of certain seedlings of Oenothera Lamarckiana which De Vries discovered growing wild at Hilversum in Holland. ${ }^{2}$

Now this species was described by Lamarck from certain specimens growing in the Paris Botanical Garden, and which were supposed to have come from America. The wild plant, if it does still grow in America, has not been found of late years. On the other hand, it has been alleged that it is not a species at all but merely a hybrid. If this is true, it is difficult to put any faith in those mutants. Even if it were a wild American species, it has experienced two distinct changes in climate (to Paris and thence to Holland), so that its variations could

* The excellent account of Weissmannism in Thomson's "Heredity" should be consulted for further details, and indeed for the whole theory of modern evolution. 


\section{Theory of Plant Breeding}

be quite simply explained as the usual changes which most new introductions go through when grown under strange and new conditions.

Many of De Vries' characters, e.g. giant and dwarf forms, colour of flowers, mode and time of flowering, are undoubtedly affected by external conditions. But it is, of course, quite well known that sports or sudden changes do appear sometimes without any assignable cause. $^{3}$

This is well marked in many garden plants which are apt to show extra petals, or become double, or to develop strangely twisted or flattened stems.

On well-nourished plants of toadflax, for instance, an extra petal may appear suddenly and the accomplishment may be inherited. ${ }^{4}$

Double flowers are perhaps due to a disease set up by parasitic insects or fungi. M. Molliard claims to have produced double flowers in Knautia arvensis and in Matricaria inodora by infecting them with a parasitic fungus (Peronospora violacea and $\mathrm{P}$. radii). $\mathrm{He}$ also got Primula officinalis to form double flowers by means of a root-fungus; other plants were also doubled by infecting them with eel-worms. ${ }^{5}$

This explains the statement, strongly insisted on by Mr. Fenn, * that single flowers are apt to turn double when grown alongside the latter. An insect could very well convey the fungus spores from the double to the single flowers. Extra nourishment is also said to favour the production of doubles.

When once formed the tendency certainly seems to be inherited, for about 90 per cent. of M. Vilmorin's seedlings inherited the character. ${ }^{6}$

An old recipe given by a Dutch florist about 1499 gives a method of making anemone flowers double.

* See R. H. S. Conference on Genetics, 1906. 


\section{Theory of Plant Breeding}

"Keep the tubers for one year, then soak them in wine, and dry them before they are sown." 7 So that it is by no means certain that double flowers appear without any assignable reason.

Fasciated stems are sometimes due to injury. If the main shoot is cut off when the plant is in full growth, then the full current of sap seems to be turned into the lateral buds, which grow out as a fasciated stem. ${ }^{8}$ Fasciation and torsion or twisting of the stem are also said to be inherited. ${ }^{9}$

Although there are all these objections to mutancy as a theory of evolution, yet there is no possibility of controverting De Vries' main position, which is that variations do arise in a way that we cannot yet explain.

Most botanists, however, had fully realised that. There is also the fact that, as we have seen (see p. I 47), it is a mistake to suppose that vegetables are wholly passive and inert in the struggle for existence. A response made by vegetable protoplasm may not at first appear very important, and yet a new enzyme might so alter the physiological state of the plant as to produce a sudden "mutant." Botanists are not supposed to sit down and wonder at such changes but to try and explain them.

Dr. Francis Darwin in his address to the British Association (1908) explains another very interesting theory so clearly and fully that the reader should refer to the original paper. A physiological state (the term used by Klebs) is compared by him to a complex habit gradually built up by the addition of new complications and fixed by continual repetition.

The botany of to-day has obtained great assistance from the experiments of the Abbé Gregor Johann Mendel. He was the son of a peasant proprietor at Heizendorf bei Odrau in Silesia, and was born in July 


\section{Theory of Plant Breeding}

1822. He became a priest in the Königin Kloster at Alt Brunn, and in the garden of this cloister carried out those careful tests which are now universally recognised as of the first importance. He became abbot of his monastery and died in $1884^{11}$

These experiments were published in 1866 and were never seriously noticed by anybody until 1900 !*

He selected two races of peas, one with yellow and one with green seed, and crossed them, with the results shown in the diagram. All the hybrids in the first generation were yellow.

\section{Yellow $\times$ Green.}

\section{All Yellow.}

I Pure Íellow.

2 Impure Yellow.

I Green.

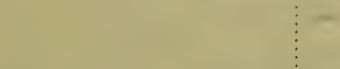

Pure I Pure Yellow. Yellow.

2 Impure
Yellow.

2 Impure
Yellow.

I Green.

Green.

Pure Pure Pure Yellow. Yellow. Yellow.

2 Impure Yellow.

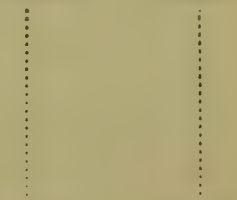

The proportions in the second generation are, as

* A translation of his original paper has been published and is still worth reading, for it is considered a classic. ${ }^{10}$ 


\section{Theory of Plant Breeding}

will be seen, three to one. The explanation as given by Mendel was very simple and effective.

We will suppose that, when "yellow" and "green" elements occur together in one germ cell, the progeny must be yellow, that is, we will suppose that yellow dominates over green, or is a dominant, whilst yellow is recessive, using the original terms.

Then if we suppose that the first generation is all mixed, we may represent them as $(\mathrm{G}+\mathrm{Y}),(\mathrm{G}+\mathrm{Y})$. If those first generation hybrids are crossed we may take their constitution as follows: GG, GY, YG, YY.

The GG are pure green, and the YY are pure yellow, but both GY and YG will appear yellow because the yellow dominates the green, so that the proportion of three yellow to one green is maintained because yellow dominates over green.

Both GG and YY are pure green and yellow respectively, and should breed true for any number of generations so far as this one character is concerned and if not influenced by change in the environments.

It is clear that this theory explains many cases of heredity "skipping a generation," and of reversion to an earlier type. So the theory is of very great importance to all hybridisers and those seeking to fix a new and valuable character. As $\mathrm{Mr}$. Bateson, the great authority on this question, has said, it may enable a practical breeder to fix his type in four instead of in ten or twelve generations.

Mendel's theory has been tested in a very large number of cases. It has been found to apply to certain characters of peas, of poultry (colour and comb), of horses (colour), of rabbits (colour), of mice (" waltzing " and colour), and especially it was found to hold in no less than 4548 pairs of specific characters in orchid hybrids.

In this last experiment conducted by Hurst, ${ }^{12}$ the re302 


\section{Theory of Plant Breeding}

sults were as follows: I I 4 IA, $2267 \mathrm{Aa}$, I I 40a. A and a being the dominant and recessive characters employed.

Perhaps the most interesting of the recent papers on this subject is another by the same author. ${ }^{13}$ Of 44 pairs of Mendelian characters, he shows that $4 \mathrm{I}$ (no less than 93 per cent.) may be explained on the theory that the dominant character is presence and the recessive is absence of some particular unit character which is in most cases a colouring substance.

Suppose one represents the first generation of hybrids by two buckets with a number of yellow and green counters (half yellow and half green in each). We may then make up the second generation by taking one counter from each bucket at random. By the ordinary laws of probability, the result of a very large number of trials would be such a percentage as $25 \mathrm{YY}$, $25 \mathrm{YG}, 25 \mathrm{GY}$, and $25 \mathrm{GG}$, which is 25 pure yellow, 50 yellow-green, and 25 pure green, giving the three to one proportion (for yellow dominates green).

So that in any case of this sort where two races are crossed which only differ in that one possesses a colouring substance, this enzyme (or whatever it may be) would be transferred in three cases out of four.

Of course it is rash to suppose that the inheritance can be quite so simple as this. The colour is probably produced as a result of enzymes formed by a series of chemical changes. The originator of the series will be passed on to the germ of those that are to possess it.

When one uses two pairs of characters, the Mendelian results are a little more complicated. Such proportions occur as $9: 3: 3: 1$, or 9 to 7 when one dominant is alone considered.

One of these complex cases has been very beautifully worked out by Miss E. R. Saunders in the case of certain stocks. ${ }^{14}$ The characters used were the glabrous or 


\section{Theory of Plant Breeding}

hoary nature of the leaves and the colour of the flowers. This last may be due to a colouring matter in the sap or to a yellow tinge in the colour of the plastids, so that four distinct conditions are possible. RC when both sap and plastids are coloured, rc when both sap and plastids are uncoloured, and $\mathrm{Rc}$ or $\mathrm{Cr}$ when one or other of the colours is present.

It was found also that hoariness is due to the presence of two ( $\mathrm{H}$ and $\mathrm{K}$ ) complementary factors, and only manifested itself when both $\mathrm{C}$ and $\mathrm{R}$ were present as well as $\mathrm{H}$ and $\mathrm{K}$.

The unravelling of this curious tangle of hybrid characters is most ingenious and gives one a very good iclea of the complicated nature of hereditary transmission.

This is not at all an exceptional case, for colours are often produced by the combination of various shades. Thus when $\mathrm{Mr}$. Hurst experimented with a red tomato ("Fireball") and the yellow-fruited "Golden Queen," he found that there were at least four kinds of fruits. In the "Fireball" the red flesh shows through a bright yellow skin, whilst in "Golden Queen " the flesh is yellow and the skin is white. Amongst his hybrids were reds with a white skin and yellows with a yellow skin.

So that the four different sorts of fruit can be explained simply by the presence or absence of red in the flesh and of yellow in the skin.

With orchids, of course, one would expect, as experimenters have found, many strange contrasts and new tints formed by the combinations of their many colouring matters.

Why should one character always be the dominant one? There has been no satisfactory explanation of this. Of course when it is the very common case of the presence or absence of a colour, then presence will dominate and absence will be recessive.

Yellow and green are rather interesting examples of 


\section{Theory of Plant Breeding}

another suggested explanation. Probably the original seed colour was green, and yellow has been formed because the plastids in certain more advanced races have stopped at the yellow stage of development, and not gone on to the formation of green. This yellow is then a progressive step in the evolution of a species, and would be, according to Davenport's view, likely to be dominant. $^{15}$ But according to Emerson (U.S.A. Exp. St., Nebraska, I902), one also finds in racial hybrids of kidney beans both new colours, and others which seem to result from some very distant ancestor (atavistic).

One very common theory amongst practical breeders, viz., that the pollen parent decides the flower colour of its descendants, seems not to be substantiated by experiment.

Chittenden found that of 183 hybrids, 42 were of the male colour, 46 of the female; 92 were intermediate, and 3 were unlike both ancestors. ${ }^{16}$ But although, as the reader will have realised already, Mendel's results will be of great service in practice, they must not be considered as all-important. Macfarlane has clearly shown that certain hybrids do not follow Mendelian laws, but form a series of transitions between the colours of their parents.

So far as Mendel's laws bear upon evolution they bring out clearly two facts-first, that such characters as colour are clearly inherited, which has an impcrtant bearing upon the inheritance of acquired characters; and, secondly, that it is unlikely that hybridising can have played any important part in the formation of new species. The tendency in hybrids seems to be for them to work back to the original parent types.

But even these conclusions are somewhat uncertain. The genus Iris has three stamens only, and one would think that this was an absolutely fixed character. Some very distant ancestor no doubt had six stamens, for that is almost universal in all allied orders. But Heinricher discovered occasional extra stamens in about 18 per 


\section{Theory of Plant Breeding}

cent. of a certain iris and which belonged to the inner row of three stamens which are usually absent.

By breeding from these exceptional irises he, in I 894 , found that 89 per cent. had extra stamens, and in 1895 that 56 flowers out of 486 had six stamens, and also had all three petals changed so as to resemble the sepals. ${ }^{17}$ So that pure races may occasionally revert even to extremely distant ancestors.

Another different question, which is also full of interest to all practical horticulturists, is the influence of the stock upon the scion, and vice versâ. Mr. Daniel has published many observations upon this question and upon grafting generally. When, for instance, a perennial sunflower was grafted upon an annual one the stock became perennial, and other characters of the scion also made their appearance on the stock.

Such characters as variegation, early flowering, fertility, resistance to cold and to parasitic fungi, have also been produced in the graft when attached to a suitable stock. ${ }^{18}$

It was by the use of American stock which were unaffected by the Phylloxera that the French and other vineyards were saved from destruction, but in this case the grafts were not (at least so far as the author is aware) influenced by the American stock.

But these difficult questions must not be allowed to occupy too much space, and we cannot do better than close this chapter with an illuminating remark by the late Professor Weldon, "There is probably no group of plants or of animals which cannot be directly modified by a suitable change in some group of environmental conditions." 19

\footnotetext{
1 Thomson.

4 Garjeanne.

7 Arnott.

10 Bateson.

:14 Saunders.

19 and 18 Heinricher, Jones.
}

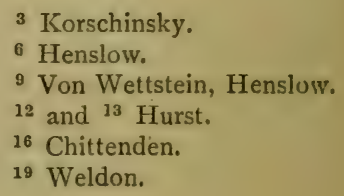




\section{CHAPTER XXVII}

\section{SCRUB}

SucH expressions as "Xerophytic hard-leaf flora," maqui, garigue, thornwood, and the like are not generally known in this country, in the sense in which they are used by Schimper and others. Nor is there any really good popular word to describe this sort of vegetation, so that we have been reduced to "scrub," which will perhaps give the idea of a scattered, shrubby, very often thorny, and always almost inedible bush, and which is very common in dry, warm and temperate countries.*

Such a vegetation as this is typical of many Mediterranean lands, of many parts of South Africa, especially near Cape Town, of the coast hills of Chile near Valparaiso, and is apparently (from description) exceedingly common both in Australia and California.

It is perhaps the most puzzling of all. If one begins to note down the various types of it to be found, say in Spain, or in Corsica, the number becomes appalling, and one very soon begins to doubt whether it is really a natural vegetation, or only a series of transitional types which represent stages in the formation of some kind of wood or forest.

Near deserts, as in North Africa, one finds thorny acacia thickets which represent one type of scrub specially adapted to invade and colonise deserts.

Where there is a good rainfall, as towards the north

* Schimper's chief character is the hard, rather dry leaf. But gummy and woolly leaves are very common. Thorns and bulbous plants are also abundant. ${ }^{1}$ 


\section{Scrub}

(in Europe), the scrub changes into temperate forests or on hillsides into pinewood.

But where there is a long dry summer, the ground is usually covered by either :-

(I) Maqui, which is a close thicket about 5 to 7 feet high, composed chiefly of Erica arborea (of which our "briar-root" pipes are made), with hard-leaved evergreen shrubby oaks, mastic, and many other shrubs.

(2) Gum-cistus, fairly close bushes of sticky Cistus, and other plants 3 to 4 feet high.

(3) Scented Labiates, placed apart from one another and 2 to 3 feet high, with quantities of other scattered shrubs, and especially with many beautiful asphodels and other bulbs.

(4) Small spiny bushes (garigue), usually less than 2 feet in height, and distantly scattered over a specially clry and stony soil.

One special characteristic of them all is that, in the whole series, all the typical and commonest plants either cannot be eaten by any animal under any circumstances, or are just edible when a goat or a donkey is starving and driven to extremities.

This fact gives a great probability to the theory held by several continental botantists that these various types of vegetation are nothing but the persistent undergrowth of what were once forests of cork-oak, of chestnut, or of some of the Mediterranean pines.

Such woods still exist in a few rare places. Dr. Willkomm describes them as exceedingly beautiful and even luxuriant. The trees of Quercus ilex, Q. lusitanica, and wild olive are covered with dark-green moss or hung with lichens as the whitish grey tassels of Usnea barbata, or the reddish-yellow and grey of Alectoria. There are plenty of ferns such as Davallia. Along the streams are huge alders, great Celtis' and bay trees 


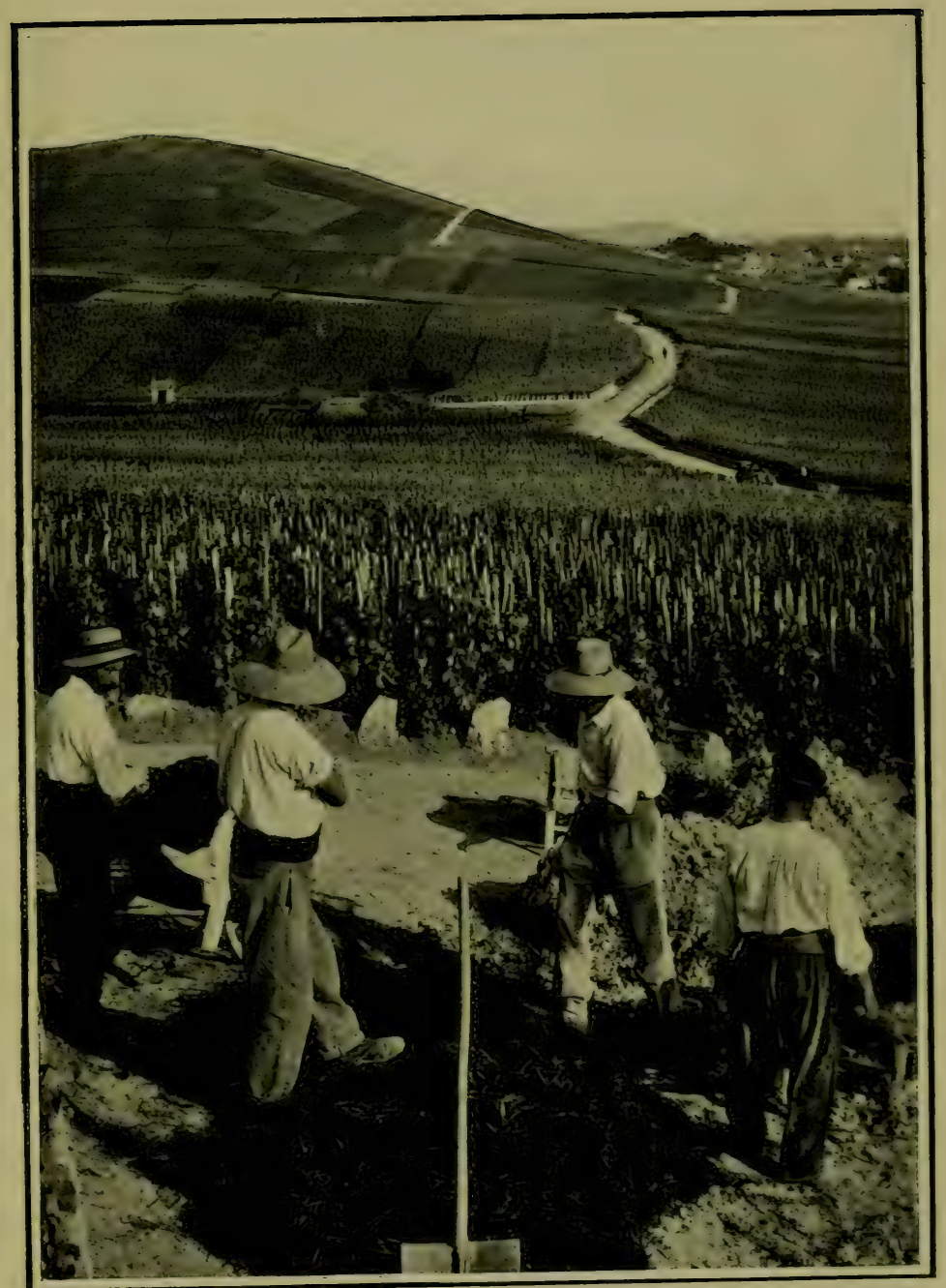

Stereo Copyright, Underzood \& $U:]$

[Lonton and New York

VINEYARDS COVERING THE SUNNY FIELDS AT Ay, NEAR EPERnay, in the Champagne District, France

Almost every acre of land is subjected to the most intensive culture. 



\section{Scrub}

(Laurus nobilis), and there is a rich undergrowth of Rhododendron ponticum. ${ }^{2}$

Unfortunately we have no means of studying the vegetation as it was in the days of Romulus and Remus, or when Hercules started on his tour of the Mediterranean.

But the character of the usual Mediterranean agriculture, and the enormous time that has elapsed since man and his domestic animals first settled in those beautiful and sunny lands, are quite enough to explain the present flora.

There is also some evidence which can be obtained from historical sources. There were, e.g. (I 550-I 600 A.D.), 30,000,000 sheep in Spain alone. They were kept in enormous flocks, and travelled every year from their summer pastures in the north to their winter quarters in the Val de Alondia, returning northwards in spring. That same system prevailed in late Roman times in Southern France, and is of course not unusual in some parts of Australia to-day. ${ }^{3}$

On the wide plains of Lower Andalusia there are now only little thorny bushes of Genista, scented Labiates, esparto steppes, or dwarf palms. But about the beginning of the sixteenth century that very district contained vast fields of wheat, as well as olive and mulberry plantations. The change is set down by historians to the expulsion of the Moors by Philip II. and his successors.

Slave-labour is particularly convenient in such a country as this, and Moorish slaves may have made cultivation possible in places where nothing could be done without slave labour.

In Braunton Great Field one can also see what must have closely resembled the present methods very often used in the Mediterranean.

The land which is under cultivation is often terraced, carefully irrigated, and painfully laboured over. Through- 


\section{Scrub}

out the long hot days, men, women, and children are hard at work in some miserably small little plot or orchard. The returns must surely be great, but as only plots of a few square feet can be treated in this way, the profit to be made must be pitifully small. The acreage which is made into rich alluvial vegas, vineyards, and olive yards, and so undergoes this intense and careful petite culture, is exceedingly small as compared with the hills and dry valleys which are left to scrub or maqui.

These are forbidding, arid, and clesolate. One learns more about the story of the scrub by watching for a few minutes the proceedings of goats, and the other hungry beasts, than could be given in many pages of description. Cattle, horses, mules, donkeys, occasionally sheep, goats, and even pigs may be seen driven out to graze by their youthful herds. All are haggard and hungry looking, with projecting bones, and have a satirical and pessimistic appearance.

Yet these vegetable demons are very efficient in their horrible task. On a rocky hillside they know better than to touch the asphodel, grape hyacinths, crocus', orchids, scillas, lachenalias, daffodils and the like, for all these beautiful and flourishing bulbs are deadly poisons. These woolly, hairy, and strong-scented lavenders, rosemaries, and the other scented labiates, are also allowed to grow as well at least as the dry and stony soil will permit.

No animal could possibly take a mouthful of the forbiddingly glutinous and sticky foliage of the gum-cistus, or the viscid and glandular leaves of some Ononis.

But any small grass seedling which has managed to put out a prostrate stem and a leaf or two not $\mathrm{I}_{2}^{\frac{1}{2}}$ inch long, vanishes with one sweep of the tongue. Should some edible herbaceous weed hide itself amongst the foliage of a lavender or a cistus, some hungry eye per- 


\section{Scrub}

ceives it, and it is promptly assimilated. Even young and still more or less soft thorns are promptly devoured. Nor are the very roots safe, for a litter of hungry pigs will systematically root up and devour the underground runners and rootlets of any edible plant.

So to any one who has botanised in other countries, the appearance of the ground in the open or between the stems of the maqui or of the cistus seems very strange, peculiar, and unnatural. It looks very dry and terribly bare, with white stones glaring in the sun, and small thorny bushes here and there. But when this desert-like character has impressed itself on the mind, some vigorous Salvia or Ocimum or Cistus, and perhaps a tiny grass-seedling or two, proves that it is not in the least like a desert.

Even the very Charlocks, Polygonums, and other weeds of cultivation are carefully saved up to feed those goats which, with tinkling bells, climb up the Spanish tenements' stairs to be milked on the purchaser's threshold.

It is in the Balearic Islands, which have a large population and a limited area, that some of these goat-effects are most impressive. There one finds a complex tangle of sharp woody thorns, quite 2 inches long, which is Asparagus horridus. Also pretty, green, mossy-looking cushions, perhaps 4 or 5 feet in circumference, but which on examination are found to bristle all over with hard and acute spinose points. That is Astragalus poterium. A curious instance of specialisation is a fragile little vetch, Vicia bifoliata, which insinuates itself amongst these Astragalus plants and is protected from the goat by their armature. ${ }^{4}$

In the Mediterranean generally there is plenty of bare ground, and probably not so much competition of plant with plant as is usual in Europe. The dangers 


\section{Scrub}

are drought, and those grazing animals of which the goat has a bad pre-eminence.

So it is not surprising to find that many useless South Africans and Americans are very common weeds, and widely spread; there are, e.g., Prickly Pears, Mesembryanthemums, Helichrysums, and Geraniums (that is, Cape Pelargoniums), Aloes, Agaves, and the like.

The general characters of scrub plants are quite clearly influenced by the climate. The connection of thorns with dry and sunny climates has already been considered.

Gumminess and stickiness is an extremely useful character, for not only are such plants unappetising morsels, but the gum is an excellent covering for wounds and cracks, and a safeguard against insects, of which there are many in such countries.

The subtropical scrub of Somaliland is the country of gum, frankincense, and myrrh. To that mysterious land of Punt, Queen Hatasu sent the first scientific exploring expedition of which we have any record, and which returned with plenty of these fragrant drugs and essences, which were in those days invaluable for mummies.

But, in the Mediterranean countries, the strong scents of rosemaries, basil, thyme, lavender, marjoram and the like are of great interest. As we have seen elsewhere, strong sunshine and pure air intensifies these perfumes, and it is in the Riviera that one finds the centre of the perfume-industry.

In the evil days that came upon the peasant proprietors in the Phylloxera invasion, here and there some courageous and energetic Frenchman (or woman, for Frenchwomen understand business) started great factories where roses, lilacs, parma violets, and the "cassie" (Acacia farnesiana) were required by the million. Thousands of acres are under flowers, and some at least of those peasants have again recovered prosperity. 


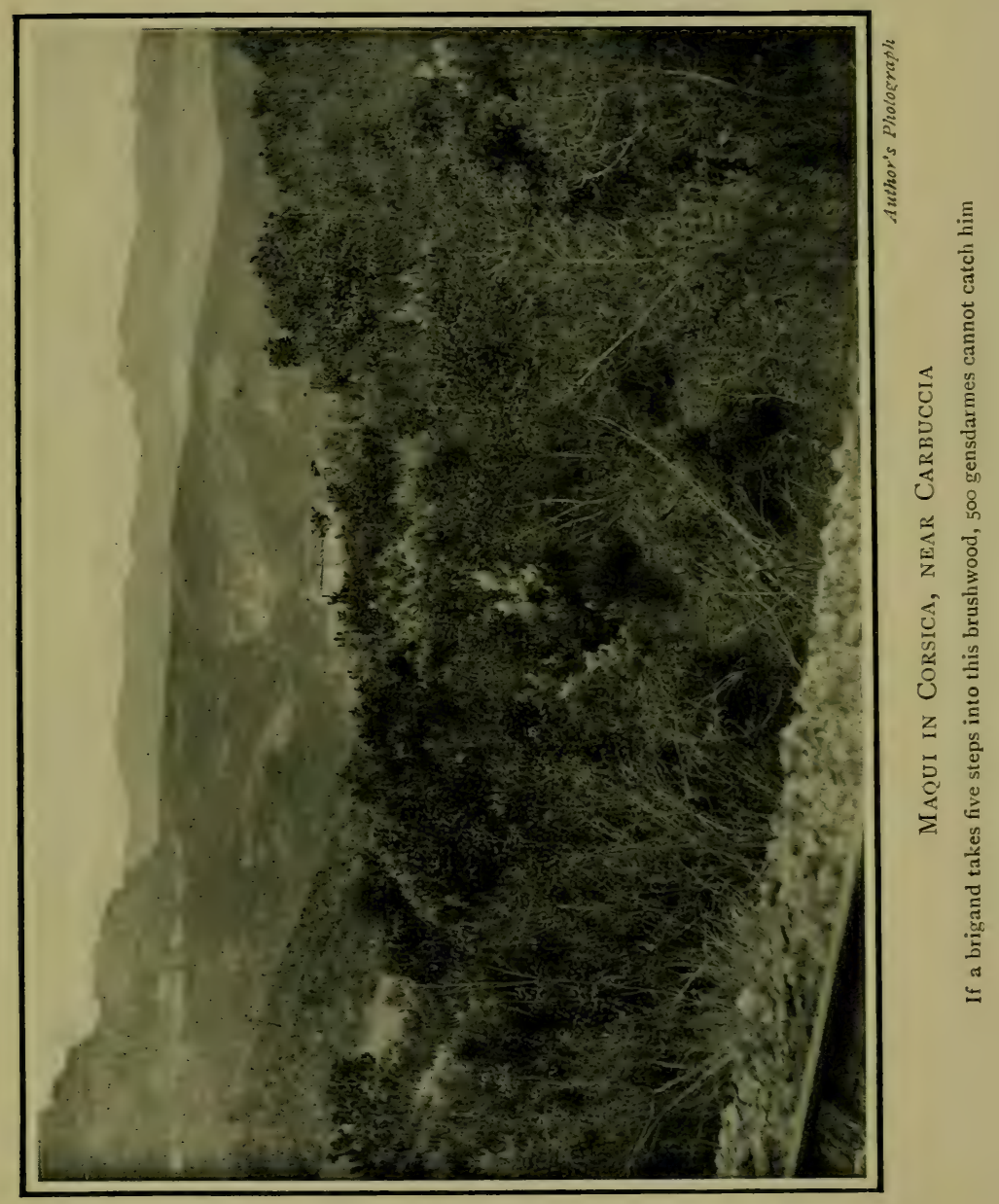





\section{Scrub}

But these perfumes are really poisons, not only to animals but sometimes to insects.

A West African Ocimum (basil) was tried as a cure for mosquitoes, and it was proved after careful investigation (I) that mosquitoes were indifferent to its smell; (2) that, if burnt in large quantities in a small room, neither a mosquito nor any human being could endure the smoke of it. ${ }^{5}$ Both fungi and parasitic insects are able to adapt themselves to all sorts of poisonous secretions, but those strong-smelling Labiates and others are certainly partially protected by these oils and resins.

There has been a great deal of doubt as to whether such perfumes (that is, ethereal vapours) form a sort of vapour-screen round a plant and so prevent the escape of water, for if so they would be decidedly useful in a dry climate. In very hot still weather they surely must be of some use, but they can hardly be of very great importance. ${ }^{6}$

The poisonous character of such oils on vegetable protoplasm has been carefully tested. When placed under a bell-glass so that the atmosphere became saturated with their own scented exhalation, peppermints poisoned themselves in eleven days, camphor plants in fifteen days, and Dictamnus in fifteen days. But if the air in the bell-glass is artificially saturated with their own vapours, lavender dies in 140 hours, and Mentha piperita in 74 hours. $^{7}$

It is the strong scented breezes that are wafted from the maqui of Corsica which Napoleon in Elba remembered whenever he shut his eyes. This maqui of thick and dense Erica arborea, mastic, shrubby oaks, \&c., covers hills and valleys and for square miles together. Even to-day it is almost true that a brigand has only to take five steps into the maqui and 500 gendarmes will never be able to discover him. This 


\section{Scrub}

fact has not been without its influence in the history of the island.

The botany of a few years hence will no doubt be able to say definitely what those various scrubs, Maqui 5 to 7 feet, Cistus 3 to 4 feet, Labiates 2 to 3 feet, and little thorn-cushions really mean as regards climate and possible use of the country by man.

This will be of the first importance to the British Empire (supposing that it continues to exist), for such scrubs are common in South Africa and in Australia.

The really difficult point is to know how much allowance has to be made for at least 6000 years of the goat, which is a vegetable Apollyon, and of other grazing animals. Carthage, Greece, and Italy became surely prosperous in the first instance by their agriculture, not by foreign commerce. Where are the cypress and cedar forests of Asia Minor and Judrea? What difference did they make in the rainfall and fertility of the Eastern Mediterranean?

The Protea or sugar bush of Cape Colony is essentially similar to the Mediterranean scrub. In South and West Australia, woody little shrubs or dwarf trees seem very often to form characteristic scrub or bush, which is perhaps botanically equivalent to the Corsican maqui. The actual plants are of course utterly different. Eucalyptus, Wattle-acacias, Casuarinas, Proteaceæ, Myrtaceæ, and Epacridaceæ replace but correspond to the Mastic, Cistus, and Erica arborea of the Mediterranean. In Cape Colony there is a true Erica association which resembles the Mediterranean associations even more closely.

There is also in California the "Chaparral" association, which has hard-leaved shrubs, dwarf oaks, a strange shrubby sort of Papaveraceæ very like the gum-cistus and many gummy plants. 


\section{Scrub}

In middle Chile there are thorny acacias in many spiny forms, gummy-leaved plants in abundance, beautiful Alstrœmerias and other bulbs, even Cereus' and strongly fragrant perennials, which show distinctly that the flora is again a typical scrub. But here again there has been much disturbance by man and his attendant domestic animals, which have grazed and destroyed for at least five hundred years.

In a general way, whatever plants grow in one of these districts can surely be made to flourish in any one or all of them. But the average Dutch Boer, Hottentot boy, Chilian peon, French or Italian peasant, and Australian do not show very much resemblance in character and are not content with similar wages, so that the question of what can be made to grow with profit is a very difficult one.

But for the patriotic South African or Australian the past history of Greece, Rome, and Spain is encouraging enough. The present state of those countries is perhaps not so promising, but their flourishing periods were those when unintelligent man had not succeeded in destroying the forests and the vegetation, and it is from the vegetation of those long past eras that the most promising hints should be obtained.
1 Schimper.
5 Prout and Hood.
${ }^{2}$ Willkomm. $\quad{ }^{3}$ Desjardins.
${ }^{6}$ Detto.
${ }^{4}$ White. 


\section{CHAPTER XXVIII}

\section{TROPICAL FORESTS}

THE very highest type of vegetation, the most complex mixture of plants of all sorts of families and of various habits, are to be found in the tropical jungle. This reaches its best and finest development only where there is no dry season, or at least none long enough or sufficiently severe to leave any distinct mark upon the vegetation. Forests in the tropics are by no means always of the same character. Unfortunately it would be impossible to explain the intricate classification which is adopted by many German botanists. Nor is there any recognised system adopted by English writers on botanical geography, which is most unfortunate.

If, however, one were to take an aeroplane trip more or less along the equator from the West Coast of Africa to Ruwenzori, the different types of vegetation which could be roughly sketched would be as follows.

Wherever, along the seashore, there are river estuaries or mud-banks, mangrove forest would be found. This extends up the rivers and creeks at least as far as the sea-water is able to penetrate.

The coast mountains will be covered everywhere with the true wet jungle forest, at least so far up their flanks as they are supplied with rain and moisture from the ocean. Of course this distance varies greatly according to the mountain heights and general contour of the continent. At Bibundi in German West Africa (where there is the magnificent rainfall of $\mathrm{II}, 900.65 \mathrm{~mm}$. (476 inches) per annum) the true wet jungle or tropical forest proper occurs right up the mountain sides to a height of 2700 metres ( 8800 feet) in the more sheltered gorges. ${ }^{1}$ 


\section{Tropical Forests}

But at Sierra Leone there is a distinct change in the vegetation even towards the summit of $\mathrm{Mt}$. Sugarloaf : the high winds and exposure prevent the continual moist hot-house heat which is required for its true development. But along a great river valley such as the Congo, the wet-jungle slightly modified may be continuous, extending up the tributary rivers and their small streams just so far as they remain so sunk below the general level of the country as to preserve this moisture. Even at about 7000 feet in the Wimi valley on Ruwenzori, one is reminded at every turn of the coast jungle at Sierra Leone.

This is not at all surprising, for there is a nearly continuous series of hot, moist, forest-clad slopes or steamy valleys right across Africa from Ruwenzori to the Congo mouth, and thence along the shore to the Sierra Leone peninsula. In the Amazon valley, so far as I can understand Dr. Ule's description, the entire valley and its tributaries are clothed with essentially the same wet-jungle forest up to the eastern slopes of the Andes in Peru.*2

But in such an aeroplane as has been suggested, one would pass sometimes over plateaux, or perhaps over slightly undulating ground, with here and there a range of mountains rising well above the general level of the country. These plateaux will not be covered with the true wet-jungle, which begins to fail a little before the crest-line of the coast mountains. Most of them will be savannahs covered by tall "elephant grass," or even by low steppe-like grasses with a few scattered trees. Occasionally the rolling hills and valleys will be "parklike," or it may be wooded, but the trees are not tall, and there is nothing like the rich undergrowth and riotous vegetation of the true wet-jungle. Every river will usually have its fringe of wood or "gallery wood."

* The inundated forest of the Amazon is different, as one would expect, from that which is above the annual floods. 


\section{Tropical Forests}

An isolated mountain range will be forest-clad towards its base; above there is a cloud-zone where different conditions prevail, and on the exposed ridges and peaks of the summit there may be a temperate and even a kind of "alpine" flora.

Where the wind can sweep freely across an open plateau or a country only gently undulating, there is nothing like the abundant rainfall or the continually moist atmosphere which characterises the true wetjungle. It is this which we must try, somehow, to describe, but it is an exceedingly difficult undertaking. As we have shown elsewhere, there are at least four or possibly five main "stories" of leaf surface. The foliage canopy of the tall trees is far above one's head and looks black against the sky. Then there are dense masses of creeper foliage; below these again are young, aspiring trees; nearer the ground there are shrubs and herbaceous plants, and on the ground itself there may be mosses, ferns, or herbaceous plants. But the eyes are bewildered by the confusion of foliages, of flowers and leaves inextricably mixed. Mosses, Selaginellas, climbing figs, Peperomias, and Arums mingle with orchids, Bromeliads, and a great variety of epiphytic ferns and the like.

But the traveller is proceeding slowly along a small winding footpath and can see very little except this tangle of exuberant vegetation. It is dark, dank, and mysterious, and the atmosphere is that of a hothouse. Here and there he finds great flowers like Gardenias, flaming Labiates, and quantities of Acanthacex and Rubiaceæ. The weird knotted cables or windings and coils of the lianas or creepers cannot fail to impress him.

As a rule the forest is exceedingly lonely and mysteriously quiet. Very seldom does he catch sight of either bird or beast. Now and then, perhaps, a crowd of gorgeously coloured and stately butterflies will be drinking eagerly from some noisome pool or objection- 


\section{Tropical Forests}

able mud on the path. Very often (on the coast) there are grey hot days when the clouds hang over it, and there is not even sunshine on the foliage far above his head. But the traveller's nights have been disturbed by mosquitoes, he is very likely full of fever and in any case is apt to be depressed, morbid, and languid.

One understands at once why some of the most degraded or lowest of the human race are only found in the depths of such forests. It is a fit home for Veddahs, pigmies of the Congo, and the savage Indians of South America.

Man has not obtained the mastery over this sort of vegetation. Indeed their very exuberance and fertility make such tropical forests scarcely more valuable than a desert.

The insect life is also abundant and exceedingly vicious. Mosquitoes, centipedes, ants, gigantic horseflies whose bite produces a swelling as large as a hen's egg, and the horrible " jigger" are characteristic of some of them. In Malaya there are the leeches, and in South America vampire-bats.

If one could use an aeroplane and skim over the surface of the foliage, one would no doubt find a vivid colour and plenty of birds and insects. In South Mexico, where one may sometimes catch sight of the foliage surface from some projecting rock, there are great patches of brilliant flowers well set off by the green of the leaves. Gorgeously painted butterflies visit them and are hunted by tree-frogs which are also vivid and bright in colour. Tree-snakes are trying to catch the frogs. There are also many brilliantly coloured birds of the most varied kinds. ${ }^{3}$

In temperate or subtropical countries all this rich and diverse life of flower, insect, bird, and beast is on or near the ground so as to be seen and appreciated, but in the tropical forest everything above looks black 


\section{Tropical Forests}

to the exhausted and languid explorer unless he happens to be a botanist. Then of course he is interested and busy from morning to night, for a lifetime would be insufficient to understand and appreciate all the problems that perplex him.

The characteristic products of such jungles are not very many. The rubber vines of Africa (Landolphia sp.) and the various rubber trees and creepers of South America, the guttapercha and rubber of the East Indies are by far the most important economically.

The peculiar white juice or latex which exudes from the stems of these Apocynaceæ, Asclepiadaceæ, Moraceæ, \&c., contains caoutchouc, resins, and other ingredients.

This latex is of great importance to the plant. It is poisonous, and is so arranged in a network of internal tubes and channels that any cut or wound will necessarily result in a plentiful flow of latex to the injured place.

Trees denuded of rubber by the natives were noticed by Bates to have been stripped of their leaves by the parasol ant and probably destroyed. Upon any wound the rubber will coagulate, and its elasticity and poisonous and resinous characteristics make it invaluable to cover over the scars and to prevent insects, fungi, or bacteria from entering. If one disregards a few rxceptional cases, rubber and guttapercha plants are confined to and invariably found in wet-jungles.

The valuable Hevea of Brazil seems to belong to the great stretch of forest country which is regularly inundated by the annual flood of the Amazon, and which is specially remarkable for its extraordinary ant-plants.

In Africa it is the Landolphias which form the main supply.

In both Brazil and Africa the rubber is chiefly a wild jungle product, obtained by native collectors who are utterly unable to foresee or provide against the 


\section{Tropical Forests}

certain destruction of the supply by reckless methods of collection. The result has been to extend the area of rubber gathering farther back into the wildest and most distant parts of the forest. In the Congo Free State the collection of rubber has been left to native chiefs, supervised by native headmen in the pay of the various companies. When the quota of rubber was not forthcoming, armies of uncivilised savages were let loose upon the offending villages.

The natural result of such methods has been atrocious cruelty, and a destruction of life and property which has at last aroused the conscience of Europe. It is doubtful whether even the slave-dealing half-Arab from Zanzibar caused as much ruin and loss of life in the Congo.

But during the last few years much capital has been invested in the plantation of rubber trees. The acreage under this new crop must be enormous. There are some $10,745,000$ trees in the Federated Malay States alone which in 1907 yielded some 385 tons of dry rubber. There should certainly be no scarcity in the rubber supply when all the new plantations come into full bearing, say in I914 to I9I6.* The oil-palm is also an important and valuable wet-jungle plant. It does not grow naturally in the real virgin forest, for it requires both light and air, and is probably one of those plants which are found in the secondary forest that springs up when the true wet-jungle has been cleared away. It is a fine tree sometimes 60 to 90 feet in height, and with leaves which may be I 2 to I 5 feet long. Its cultivation is extending, and oil-palms are said to be grown even on Nyassa and Tanganyika. ${ }^{4}$

There are also many other valuable plants which are cultivated in what used to be the true virgin forest, such as arrow-root, beniseed, kola-nuts, sago, manioc, and several valuable timber trees and drugs.

* Journal of the Society of Arts, January I, rgog. 


\section{Tropical Forests}

Such colonies as Sierra Leone are amongst the oldest possessions of Great Britain, so that it does seems strange that, in spite of the extraordinary fertility of the soil, or rather on account of it, plantations have very seldom been successful. The abundant vegetation and moist atmosphere produces a climate which is quite unsuitable for Europeans and even for natives. Both management and labour are apt to become expensive and unprofitable under such conditions. Nor has any planter any reasonable expectation of living until his plantations pay. The improvement during the last few years has been, however, of the most astonishing character.

The fact that a mosquito carries the germ of malaria from one fever-stricken patient to those as yet unaffected, has made it possible almost to exterminate malaria in some places, and to reduce the death-rate enormously. Perhaps the most striking instance of the advantage of Sir Patrick Manson's great discovery is the fact that the death-rate at the works for the Panama Canal has been reduced amongst the white employees to 16.7 I per thousand. ${ }^{5}$ This district was notorious as amongst the most deadly to Europeans of all climates in the world.

Besides this great discovery, the history of sleeping sickness is beginning to be understood. The tsetse-fly is said to convey the blood-parasite or trypanosome from man to the crocodile, and possibly back from the crocodile to man. There has not, however, as yet been devised any method of exterminating either tsetse or crocodiles. $^{6}$

Even in West Africa, the mere fact that the land is steadily coming under real control by the white man, enormously alters the prospects of the future. When there is real security for life and property, both the native population and the amount of cultivation will increase enormously.

The first destruction of virgin forest for crops of any 


\section{Tropical Forests}

kind is a very difficult undertaking. But when once a strip of such jungle has been cut and burnt off, it will, after a few years under crops, be allowed to relapse into bush. Secondary forest will spring up which is by no means so dense or so difficult to clear away as the original jungle. Possibly after some seven years in bush it will again be brought under crops. All this clearance and destruction of the wet-jungle enormously improves the climate, especially from a white man's point of view.

In Southern Nigeria, according to an interesting report just published, ? a strip of forest 1000 yards wide along both banks of the river has been by law reserved, so that the wet-jungle seems already to require protection by the British Government.

This same report also contains an excellent account of the way in which in "dry zones" the natural woodlands tend to be replaced by grass (see above, p. 268). Where the rainfall is less than $5^{\circ}$ inches, the natural bush cannot hold its own against fires. Some young trees are destroyed and others injured. Grasses are not killed by these fires, but all valuable dead leaves and other good material is burnt up, and in consequence the land deteriorates steadily. So that there really is some hope that the wet-jungles of Africa and South America will no longer bid defiance to civilised man.

In Bombay, in those early days when Europeans first established a factory, the mortality was terrible, and quite as bad as it used to be in Old Calabar from 1880 to 1890 , and this fact is of course quite encouraging for Old Calabar. Mangrove swamps are quite distinct and different from the ordinary wet-jungle.

The estuaries of tropical rivers are often of enormous extent, for any large stream is apt to split and divide itself into a complex series of winding creeks, a vast confused delta, where the air is for ever hot, moist, 


\section{Tropical Forests}

heavy, and full of reminiscences of decaying vegetation. Generally dull grey clouds cover the sky and increase the oppressiveness of the atmosphere. Such estuaries are covered with the remarkable mangrove-forests. There is neither cold nor drought to check in any way the riotous luxuriance of their growth, nor that of the ever-recurring birth of millions of objectionable insects.

Mosquitoes especially swarm along the creeks and river branches, which extend for many miles inland and are everywhere fringed by those monotonous mangroves. Here and there a crocodile may be seen reposing on the sand, for fishes abound in the water as well as manatees and other unusual animals.--

Monkeys occasionally visit the creeks at low ticle to feed on the oysters which grow on the mangrove roots. At low tide the appearance of the banks is quite unique. There is no firm, solid ground, but instead a dark blackish or brown slime of very unprepossessing appearance and exceedingly deep. From its depths bubbles of objectionable gases often arise and burst on the surface-mud, in which a small perch may be seen squattering about or climbing up by its winglike fins on to a mangrove root in order to rest, gasping, in the air. Out of this loathly mud rises the wilderness of mangrove roots, of which each tree has a large number. They curve outwards in a complicated system from the base of the trunk so as to form a series of buttresses rising boldly out of the mud. The root system of each tree is entangled with that of its neighbour, which gives it a very strange appearance. Very odd growths, rather like asparagus shoots, are the air-roots by which oxygen penetrates to the root-system.

The foliage is clense and of a glossy green ; the leaves are smooth, not unlike those of laurels or rhododendrons, though some possess a long and fine tip (see p. 188). From the branches long roots hang down towards the 


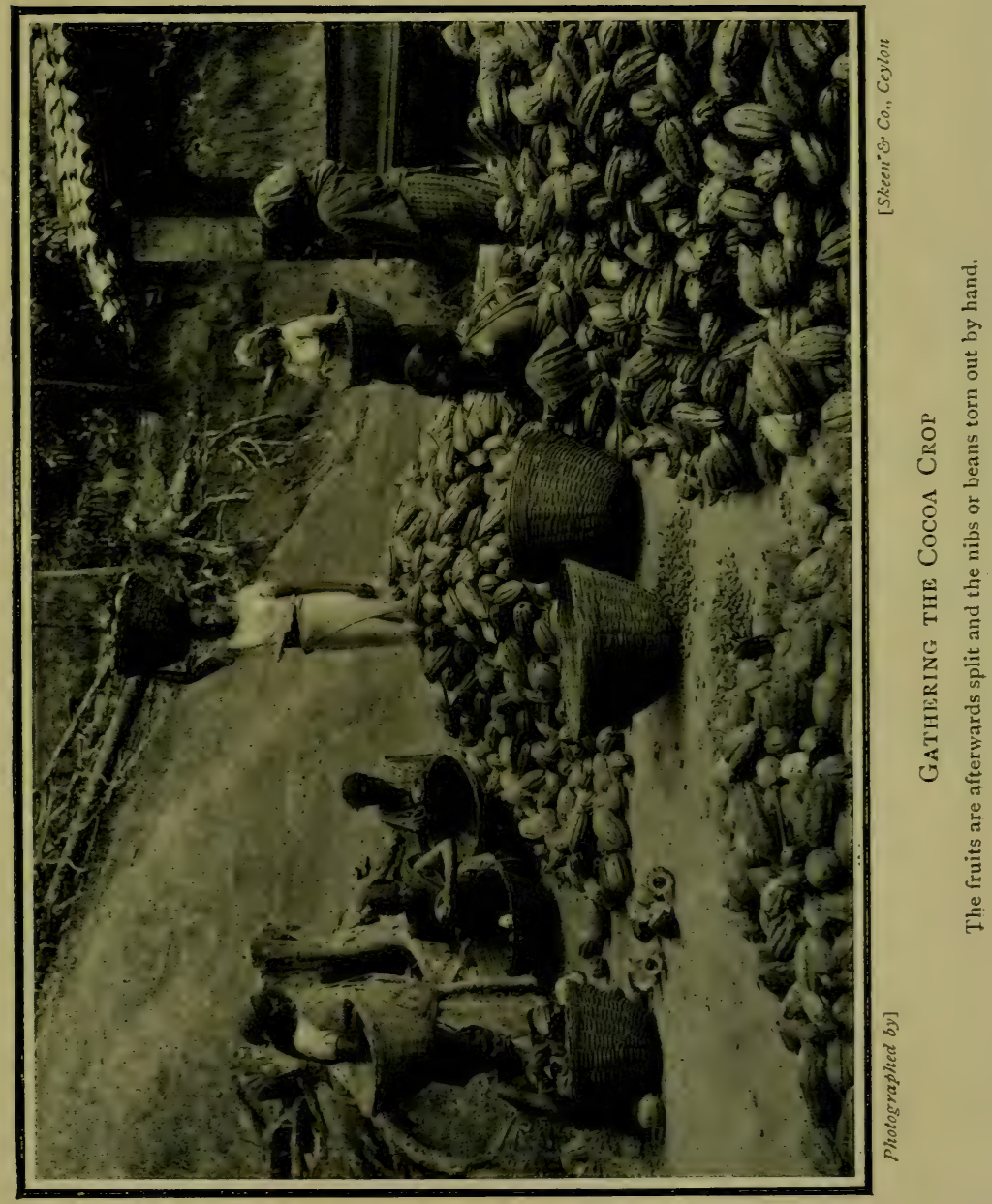





\section{Tropical Forests}

water. Each root, as soon as it approaches the level of high tide, breaks into four or five rootlets exactly like grasping fingers outstretched to lay hold of the mud.

When the tide returns and fills the whole system of creeks and lagoons, new deposits of mud are continually being laid down, and new banks are formed. If some such root manages to reach one of these banks it soon establishes itself upon it, and the mangrove swamp has gained a piece of new territory.

But in this process the seedlings of the genus Rhizophora are also important. The seed begins to germinate whilst in the fruit and still attached to its parent tree, which is a most unusual proceeding in the vegetable world, for there is no period of rest, as is usual with almost all other plants. After the flower is fertilised the seedling continues to grow for about thirty-three weeks before it finally falls out of the fruit. By this time the rootlet is about 9 to Io inches long.* 8 Then it begins to free itself forcibly from the fruit by a very remarkable swelling which appears at the base of the seed-leaves.

If the seedling falls into mud it will at once take root and vigorously grow into a new mangrove; the outer muddy edge of the mangrove swamp may show quantities of such young trees trying to establish themselves.

But if it drops off at high tide, it floats freely in the water. In fresh water it will be upright, but in salt the young seedling generally floats horizontally. Quantities of such mangrove navigators may be found even ten or twenty miles off the shore, and they may be carried by the currents towards perhaps some as yet uncolonised estuary. They can float without any sign of injury for at least four months.

Perhaps it is in this way that the mangroves on the

* Rhizophora mangle, see Guppy, l.c. It may be 3 feet in other species of Rhizophora. 


\section{Tropical Forests}

east coast of America have been carried right across the Atlantic to the West African shore, for there are two distinct mangrove associations. One occupies the shores of the Pacific and Indian Ocean, and the other occurs on both sides of the Atlantic.

But where mangroves have established themselves, they are of very great importance as land-formers. Mudand sand-banks are first colonised by Rhizophora or Brugueira, whose seedlings can also float for a long time (II7 days). Then the other mangroves assist to form the usual swamp, with its "dense dark wall of foliage, from which the light is reflected." 4

As time goes on, the mangrove pioneers are always annexing new territory from the sea, whilst further inland the level of the mud is slowly rising by the regular deposits at every tide. When the salt-water no longer reaches their roots with every tide, the mangroves begin to be unhealthy and give place to other trees and shrubs.

Whether this is because the mangroves require a daily salt-bath for health, or because they cannot compete with these plants of ordinary soil, does not seem to be quite understood.

The first invaders of the mangroves are for the most part certain special transitional forms of trees, shrubs, and climbing plants.

Their reign is, however, soon terminated by the invasion of the tropical forest, which in the end covers with dense jungle what was once estuarine mud, and which may be cleared away for oil-palms, for rice-fields, or other valuable plantations.

\footnotetext{
1 Von Faber.

2 Ule, Spruce.

${ }^{3}$ Gadow.

4 Von Faber.

5 Vaughan-Cornish.

6 Cantlie.

7 Colonial Reports Misc., No. 5 I.

s Schimper, Guppy. See also Engler.
} 


\section{CHAPTER XXIX}

\section{ON EVIL IN SMALL DOSES}

IN all our theories of evolution there is a gap, and one that is fatal, for no argument can be considered complete, rounded off, and quite satisfactory until it is adequately filled in.

This weak point is the origin of variations. We have seen that climate-changes produce, in all vegetable cells, modifications which are of the nature of fitting responses to a new crisis. But how and why are those modifications, those fitting responses always or at any rate so frequently ready to deal with the new emergency?

It is no answer to refer with Weissmann to the germ cells, which are, according to him, immortal, irresponsible, and entirely uninfluenced by the experiences of the individual.

The mutant of De Vries is again not an explanation, but a new name for a change of type.

Many attempts have been made to trace the number and character of variations by direct observation and measurement.

Some of these researches involved an enormous amount of arithmetical calculation and of mathematical ingenuity which unfortunately makes it impossible for any one save mathematicians to appreciate them as they deserve. ${ }^{\mathbf{1}}$

But on the whole these biometrical researches distinctly show that in any one generation, and if a single measurable character is taken, the majority of individuals are found to have the average character, and that those 


\section{On Evil in Small Doses}

who are markedly above or below the average are very few. The number, for instance, of individuals in England who are below 4 feet 6 inches or above 6 feet 6 inches in height is exceedingly small. The number who are 5 feet or 6 feet in height is very great indeed, but probably insignificant as compared with those who are between 5 feet 5 inches and 5 feet 7 inches.

This natural variation about the mean has been tested in many ways. Thus in order to get rid of the effect of changes in the environment and the effect of crossing in the ancestry, Johansen established "pure lines" by breeding from a single seed, and endeavoured to trace the character of the variations in its descendants. ${ }^{2}$

The results seem to show the usual variation about a mean character as roughly sketched above.*

As has been shown in a previous chapter, practical men do, as a matter of fact, obtain valuable varieties by breeding from extreme individuals much above or below the average in one particular character.

In certain experiments with 40,000 sugar-beets, Messrs. Kuhn at Naarden in Holland found that the amount of sugar varied from 12 per cent. to 19 per cent., with an average of $\mathrm{I} 5.5$ per cent. By selection it has been found possible to raise the average quite perceptibly, ${ }^{3}$ so also with the percentage of proteids and of oil in Indian corn.

But by such methods the selectors are just waiting on the plant's whimsies in the way of variations.

If we could affect or stimulate such tendencies to extremes, even if we could, by artificial means, changes of culture, and the like, set it varying, the benefit would be enormous. The whole process of improvement would be accelerated, and we might incidentally obtain that complete, rounded off, and satisfactory theory of evolution which has not as yet been discovered.

* It was first clearly stated by De Quetelet. 


\section{On Evil in Small Doses}

The researches of Klebs ${ }^{4}$ have shown that it is possible to do this at least in some particular cases, and they have, in consequence, an extreme importance which has not yet been realised by practical breeders.

When a vegetable is exposed to a dangerous crisis, which happens continually, it always tries to resist and defend itself.

Suppose a hungry and thirsty root to be growing in a stubborn sand composed, let us say, of aluminium, silicates, and such like refractory material, then the very extremity in which it finds itself causes the root to respire harder, that is, to take in more oxygen and give out more carbonic acid. But this very carbonic acid given off is, in water, a powerful solvent, and will attack those flinty particles and furnish more food material to the root.

Fungi seems to be even more efficient in dealing with stubborn soils than ordinary root-hairs, as, for instance, those lichens which attack granite or even quartz. The common mould-fungi are able to excrete not only carbonic acid, but malic, tartaric, formic, and lactic acids. This formidable array of assisting acids helps them to corrode granite, basalt, and even quartz sands. ${ }^{5}$ These secretions will surely be increased by the stimulus of hunger, just as happens with the ordinary respiration of roots (see below).

The effect of salt upon the living protoplasm of seaside plants has already been mentioned. Common salt is a deadly poison when in excess, yet several plants have not only trained themselves to live on salt-banks but do not seem, at first, to be quite comfortable when their customary poison is removed, for Salicornia seedlings are said to germinate better in salt than in fresh water.

It has been found that several very poisonous mineral salts, when given in minute doses, stimulate the growth of certain fungi. This holds true of zinc sulphate and 


\section{On Evil in Small Doses}

other salts of zinc, of iron sulphate and lithium chloride when Penicillium and other fungi are treated with them. ${ }^{6}$

When growing peas and vetches are watered with minute doses of copper sulphate such as .00000287 per cent. they are distinctly improved and grow more rapidly than usual, but a poisonous effect was at once noticed even when the solution was only .0000287 per cent.?

So also with sodium fluoride and many other poisons.

When trained by gradual increase of the poison, fungi can sometimes be made immune to their effects. A yeast has been educated to live in a solution of $200 \mathrm{gr}$. per hectolitre of fluoric acid ( 7.05 ounces in 22 gallons) which is at once fatal to untrained yeasts (see Chapter III.). ${ }^{8} \quad$ Very small amounts of chloroform favour the assimilation of green plants, which are, of course, killed at once by larger doses. ${ }^{9} \quad$ Even alcohol, when in very dilute solution, accelerates the streaming of protoplasm, but the movement is very soon checked and may be stopped altogether if the dose is too strong. ${ }^{10}$

It is just the same with ether, which has been found exceedingly useful in inducing the lilac to flower before the usual period, although it is a distinct poison when in excess.

So also as regards electricity and even extremes of temperature, it seems to be true that an evil in small doses is an excellent stimulus, whereas too much of it is fatal (see p. 2II).

Swarm spores, bacteria, and other free swimming plant spores are neutral, attracted, or repelled according to the amount of heat. ${ }^{11}$ A severe frost $\left(-\mathrm{I} 2^{\circ} \mathrm{C}\right.$. $)$ is said to improve the vigour of germination in the spores of rust-fungi, and also to improve potatoes ${ }^{12}$ (see p. 293).

Perennials are said to bloom earlier and to be more vigorous in the spring if they have had very cold weather ${ }^{13}$ during the winter rest. 


\section{On Evil in Small Doses}

A great many other cases might be quoted to show how general seems to be this law, viz., that something evil is an excellent stimulus if administered in small doses. But it will be better to show exactly what happens in crises of this kind.

Certain gladiolus bulbs were carefully tested in order to find out the exact amount of carbonic acid given off in ordinary respiration. These bulbs were then treated with the utmost cruelty. Some were poisoned with ether, and were found to breathe five times as quickly as they did under normal conditions; others were placed in a high temperature, and these also breathed at double the rate.

Some were submerged in cold water for twenty-four hours, and others were bruised and injured in various ways, but in every case the result was a more rapid and intense respiration. ${ }^{14}$

When onion bulbs are cut or slashed, every wound increases the amount of carbonic acid given off in respiration.

When potatoes are cut, or the seedlings of various vegetables are injured by removing the root-tip or slicing the cotyledons, the respiration increases in every case, and only becomes normal after the wound has been healed..$^{15}$

But it has also been found that when plants are suffering from the attacks of fungi or of insect enemies, their respiration is more intense. Not only so, but when a rust-fungus has established itself upon a living plant, all the normal life-processes are intensified and accelerated. More water is given off in transpiration, more sugar and other material is produced by assimilation, and the breathing is also more rapid and vigorous. ${ }^{16}$

We have already mentioned the efforts made by a leaf to cut out an injured spot by a sort of surgical operation performed of its own initiative. The growth 


\section{On Evil in Small Doses}

of cork on injured stems, and the great and unusual flow of resin whenever certain Coniferæ are wounded, show a distinct effort of the plant which must surely be the result of a stimulation of its life-processes. When the balsam fir (Abies balsamea) is attacked by a rustfungus, it also responds by increased resin flow and by forming a larger number of bud-scales than usual. ${ }^{17}$

Nor is it only the flowering plants which show the power of dealing adequately with an emergency of this kind. ${ }^{18}$ Polyporus and Coprinus, when their sclerotia are injured, are able to form a new brown protecting envelope.

All these and many other instances show that evil in small doses is often a strong stimulus, which somehow calls into existence adequate remedies.

It is only by its strange power of secreting some appropriate substance that vegetable protoplasm can deal with such situations.

Of this power there are many remarkable instances. In the life of a palm leaf, for instance, there comes a time when the old and dead leaf is a nuisance rather than a help to the tree. Then one finds remarkable modifications going on near the base of the leaf-stalk. First a continuous group of cells, across its base and at an angle of 45 degrees to it, deposit cork in their walls; then, beyond these, the walls of the neighbouring cells degenerate into some jelly-like modification of cellulose. When wet weather comes, this gelatinous material swells so that the cells become spherical, and in consequence the great leaf drops gently and softly away, leaving a well-corked scar by which no fungus can enter. ${ }^{19}$

The whole of this complex procedure has been arranged simply by the secretion of cork and the change of cellulose into its gelatinous variety in one part of the stalk! 


\section{On Evil in Small Doses}

So also with the thickening of the epidermis walls when a plant is exposed for the first time to desert conditions; particle after particle of protoplasm is, so to speak, "hurried to the front," and there secretes itself into cellulose until the outer wall, the first line of defence, is so thick that no harm can arise to the live protoplasm within. But it is upon the method of, and resistances to fungus attacks, that we have the most valuable of recent researches.

The first effect is to stimulate the living protoplasm of the leaf cells. It has been found by direct testing that the amount of enzymes is greatly increased. In cliseased mulberry leaves there are more diastases, invertases, and oxydases than under ordinary circumstances. ${ }^{20}$ One can realise what is going on in such cases from the vivid account given by Miss Gibson of one of her experiments.

A rust-spore (Uredo chrysanthemi) was placed upon the leaf of a chrysanthemum. The spore put out its tiny but deadly germ-tube, which felt its way to a stoma and then grew down, through the opening, into the leaf. Then the battle between the secretions of the fungus and the counter-secretions of the leaf cells continued for four days. But the leaf conquered, for the fungus-tube withered and died. Yet it was not won without some loss, for a circle of dead leaf cells marked the battlefield. ${ }^{21}$

$\mathrm{Mr}$. Salmon actually interfered in a struggle of this kind, and with disastrous results, so far as the plant was concerned. There are certain mildews (Erysiphe) which attack the leaves of Brome-grasses. He found by experiment that one of these mildews was unable to attack a particular Bromus. Then he began to help the fungus. He sliced a very tiny piece of the surface away from the under side of a leaf. This depressed its vitality and it succumbed to the attack. Even a slight 


\section{On Evil in Small Doses}

touch with a hot razor has the same effect, or, if the leaf is slightly injured by anæsthetics, it loses its power to keep off the enemy. ${ }^{22}$

The fact that it is enfeebled larches which fall a prey to the clisease has been recently insisted upon. It does not matter, apparently, what brings about this depressed state of health, but whether it be injuries due to a roebuck or frost or bad soil, the result is that the fungus is the conqueror. One might almost say that it is a general rule that healthy plants resist when weaker ones are invaded by parasitic fungi. ${ }^{23}$

These mildew and rust-fungi are specialists; there seems to be a particular form of most of them which confines its attacks to one kind of host plant. They cannot infect other species, unless by some accidental weakness in the particular individual.

But this is not always the case, for the South African Nemesia, but lately introduced into our gardens, has been successfully invaded by the common rust-fungus of the Scotch fir.

When wheat was first introduced in America and in our other colonies, the destruction of the crops by rust seems to have been very great, and incleed seriously influenced their prosperity during the first few years. Can this be explained by the feebleness of the wheat which found itself in a new and strange climate?

Once a fungus has established itself on a wounded leaf, it is able to infect healthy leaves of the same plant without any difficulty whatever. It was found that old and probably rather infirm blueish-green leaves (of Galium silvaticum) can be infected by a certain fungus, whilst young fresh green leaves vanquished it. ${ }^{24}$ Not all fungi are parasitic, for many kinds live entirely upon dead and decaying vegetation and are unable to attack live plants. But it may be possible to train one of the 


\section{On Evil in Small Doses}

first or saprophytic fungi to become a parasite. This seems to have happened in the case of the very common Cladosporium herbarium, which may become parasitic on apple trees. ${ }^{25}$

A very interesting experiment was also carried out by $\mathrm{Mr}$. Massee. He used a certain destructive pest of the cucumber and trained it to live on decoctions of cucumber leaves. When it had got well accustomed to these conditions, he chose some begonias (the fungus never attacks begonias, which belong to a different group of plants). He first injected decoctions of cucumber leaf under the epidermis of the begonia leaf, and then placed the spores of his trained fungus upon the epidermis.

The germ-tubes of the fungus entered the begonia stomata, discovered the cucumber decoction, and lived on it ; but after a time they began to attack the leaf cells of the begonia, and soon became begonia parasites. It is a difficult moral question as to whether this was justifiable, but it is a very interesting result. ${ }^{26}$

All these facts as to the ways of fungi throw very great light on the battle of secretions that must ensue whenever a live leaf-cell is threatened by some enemy.

There is one remarkable instance in which flowering plants have not only conquered their adversaries but have even enslaved them or turned them into useful bond-servants.

The root-fungus, or Mycorhiza, of flowering plants was surely at one time a mere parasitic foe, but it is now extremely useful, even to trees, which utilise the fungus's powers of absorption and rapid growth to their own advantage.

Almost all trees, numbers of shrubs and flowering plants, ferns and their prothallia, possess this Mycorhiza. 


\section{On Evil in Small Doses}

Whether in the mosses and liverworts it is still a parasite or of some use seems to be still rather uncertain.

Indeed if we take the whole complex series of associations with which we have been concerned in this book, something of the same kind seems to happen continually.

The invasion of algæ by bacteria or of others by fungi seemed at first to be altogether distressful. But it resulted in the great and most useful group of lichens.

Then, again, when the first rude mosses or ferns took to living on dry land, the conditions of strong sunshine and exposure must have seemed to them very hard and destructive to all vigorous and healthy living.

Yet the stimulus of these new evils led to a vigorous response which has resulted in the world's colour becoming green through its nearly continuous covering of vegetable life.

The first visits of insects to cones and the pilfering of spores by them could surely have been nothing at first but an unmitigated nuisance, involving serious loss of invaluable material.

What has been the result?

The development of the world of flowers as well as of those hovering crowds of dainty and complexly fashioned butterflies, bees, and hoverflies who have become servants and yet selectors of the best and most beautiful blossoms.

Even when woods, grass-lands, and scrubs had so covered the world's surface that deer, cattle, goats, and other herbivorous animals had developed into enormous armies, the destruction caused by them is not always, as we have seen, without redeeming features. It has not only led to valuable substances, such as resins, indiarubbers, drugs, and poisons being formed, but some- 


\section{On Evil in Small Doses}

times, as we have tried to show, they have decidedly helped and not hindered vegetation.

Now that man has proceeded so far with the great undertaking of subduing the earth and making the most of every green herb and fruitful tree, his rôle is changing ; once a mere vegetable Apollyon, he is now rather a beneficent guardian angel, intelligently cherishing flowers, grasses, and forests, and calling them into existence even in places where vegetation by itself can make no progress.

Surely then it is one of his first and most pleasant privileges to take a kindly and intelligent interest in every flower and weed and tree. To know its name is not a difficult matter, but to understand how it lives in one particular spot and its meaning in the scheme of the particular association to which it belongs, those are difficult problems as to which as yet there is but little that is certainly known.

There is only one other point which falls to be mentioned here. Not very long ago it was supposed that protoplasm could be explained, by physics and chemistry, as a mere machine, no doubt a complicated and intricate mechanism, but still essentially a machine. This led to a gross and blatant materialism which, happily, seems to be in process of vanishing away.

Now, many of our best and most honoured teachers have accepted the fact that protoplasm is alive and therefore differs altogether from machinery. Surely a humble and reverent spirit always distinguishes the real student of nature.
1 Biometrika.
2 Johansen.
3 De Vries.
4 Klebs.
5 Kunze, Stahlecker.
6 Nakamura, Watterson.
8 Klöcker.
9 Kegel.
10 Ewart.
$?$ Masayasu.
12 Erikson.
13 Knight, Krasan, and Frank.
11 Kolkwitz.
15 Richards.
16 Montemartini.
17 Andersson.
14 Zalenski.
19 La Floresta.
20 Shibata.
21 Gibson.
${ }^{23}$ Cieslar, Sorauer.
24 Neger.
25 Chittenden.
18 Massart.
22 Salmon.
26 Massee. 


\section{BIBLIOGRAPHY}

Adamovic, Engler's B. Jalurbuch, vol, xxvii., r899-I900; vol. xxxvi., I905.

Aitken, (1) Nalurc, vol. xli., I89r ; (2) B. S., Edinburgh, vol. xix., I89ז.

Anderson, Lake Ngami, 1856.

Andersson, (I) B. Centralblall, xcv., I904; (2) B.

Centralblatt, Bd. 1xxv., I898.

Anon., Jour. Roy. Hort. Soc., I902, p. 977.

Arctowsky (see Murray), Gcog. Jourr., July I 899.

Arnott, T. Nat. Hist. Soc., Dumfries, vol. xvii., p. 45.

Arthur, Jour. Roy. Hort. Soc., vol, xxvi., p. 223.

Bachmann, Ber. d. dcul. B. Ges., xxii., I904, p. гог.

Bang, B. Centralblatt, xcv., I904, p. 2 I.

Bartholomew, Physical Atlas.

Bateson, (I) Jour. Roy. Horl. Soc., vol. xxvi. ; (2) Mendel's

Principles of Heredily, I902.

Baudouin, Conr. Rend., t. cxxxviii., p. Iooo.

Baumann. See Molisch (2).

Biffen, Conference on Genclics (Roy. Hort. Soc.), I 906.

Biometrika (Journal).

Birger, Engler's B. Jahr., xxxviii.

Blackman, New Phytologist, iii., I904.

Blackman and Matthaei, Amuals B., I 902.

Blaringhem, Com. Rend., t. cxl., I905.

Bonnier, Cours de Botanique, I90I.

Boodle, (I) New Pliytologist, iii., Igot; (2) Jour. Linnean

Soc., I904, p. 659.

Borgesen, B. Centralblatt, vol. xcviii., I905.

Bose, Plant Response, London, I906.

Bottomley, Nature, I907, p. 7I.

Bower, Origin of a Land Flora, 1907.

Brandis, Jour. Linnean Soc., vol. xxxii., p. 2 I2.

Bruyant, B. Centralblatt, Bd. xcix., I905, p. II. 


\section{Bibliography}

Buchenau, Festsclirift zu Ascherson's Geburtstag, I904.

Bucher, Jalir. f. w. Bot., I906.

Burdon, Just (3), I905, p. 334.

Burkill, Jour. Linnean Soc., vol. xxxi., 1895, p. 216.

Buscalione and Traverso, Atti B. Ist. Pavia, vol. x., I904.

Buttenshaw, Jour. Roy. Hort. Soc., June 1907.

Cannon, Just (2), I906.

Cantlie, Jour. Soc. Arts, Jan. 20, I909.

Catterina, C.B. f. Bakter. Abth., ii., xii., I904.

Charabot, Les Manifest. chimique d. l. vie végètale, 1903.

Chardot, Com. Rend, I906, p. I42.

Chodat, Bull. s. b. Geneve, I904 \& 1905.

Chittenden, (I) Jour. Roy. Hort. Soc., Nov. I908, p. 253 ;

(2) Genctics, I906, p. 2I3; (3) Jour. Roy. Hort.

Soc., vol. xxxiii., p. 509 .

Chrysler, B. Gazette, vol. xxxviii., I904.

Chun, Just (I), I905, p. 687.

Cieslar, (I) Just (I), I904, p. 6I7 ; (2) C. B., Forstwesen, I904; (3) see Somerville.

Clauditz, Hygien, Rundschau, I904.

Cockayne, (I) Kew Bulletin, I908, No. 6; (2) see Schimper ; (3) Nero Pliyt., iv., I905.

Colonial Reports, Miscellaneous, No. $5 \mathrm{I}$.

Cooke, British Fresh Water Alga.

Correns, Jaltrb. f. w. Bot., I907, 1908.

Costantin, L'Hercdité Acquise, I902 (see Henslow).

Coupin, B. s. b. de la France, I905.

Crispin, Gcog. Jour., Sept. I902.

Cserey, Just (I), I905.

Darbishire, Amuals B., I904.

Darwin, Dr. F., Address, Brit. Assoc., 1908.

Dauphin, Com. Rend., clxxxviii., 1904.

Davenport, Conf. on Genetics (Roy. Hort. Soc.), I906, p. I38.

Dawson, Annals B., I90I.

De Vries, Plant Breeding, I906 ; Species and Varieties, 1907.

Dengler, Untersuch. u. d. Horizontalverbreitung $d$. Kiefer (Neudamm), I904.

Desjardins, Géographie de la Gaule Romaine. 


\section{Bibliography}

Detto, (I) Flora, xciv., I905 ; (2) Flora, xcii., I903.

Diels, Die Hochalpin, Flora Ostasicns (Teg. d. Erde).

Dietel, C. B. f. Bakt., I904.

"Dismal Swamp Region," Jour. Roy. Hort. Soc., Oct. I8, I903, p. 248.

Dixon and Whigham, Notes B. School, Dublin, March 1905.

Dop, B. d. l. s. b. de la France, I904, I905.

Dorn. See Molisch (2).

Druery, Conf. on Genctics (Roy. Hort. Soc.), I9o6, p. 273.

Dunn, S. E., Naturalist, I901.

Elliot, R. H., Agricultural Changes, \&c., Kelso, 1905.

Elwes and Henry, British Trees.

Emerson, U.S. Expt. St., Nebraska, I902.

Engler, (I) Annals B., Oct. I 904 ; (2) Englcr's B. J., xxxvi.,

I905; (3) T'icrtcljahrs. d. naturw. ses., Zurich, I906.

Erikson, Bull. Herb. Boissier, t. iv., I896.

Errera, Rec. Inst. B. Univ. Bruxelles, I903.

Erwin Smith, Conf. on Genctics (Roy. Hort. Soc.), I 906.

Ewart, (1) P. Roy. Soc., vol. 1xxx., p. 36 ; (2) Jour. Limnean

Soc., No. 2 I7 ; (3) Plyysics Streaming Protoplasm, I903.

Ewart and Bayliss, P. Roy. Soc., lxxvii., I906, p. 33.

Farmer, P. Roy. Soc., vol. lxxix., p. 448.

Fechner, Nanna oder ïbor das Scolenlebon d. Pflanzen.

Fenner, Jahrb. f. w. Bot., I904, p. 335 .

Figdor, Jalurb. f. w. Bot., I907.

Fink, B. Gazette, vol. xxxviii., I904.

Fitting, Jalurb. f. w. Bot., xli., I905.

Foulerton and Kellas, P. Roy. Soc., vol. 1xxviii., p. 85 .

Frank. See Henslow (I), p. I20.

Freeman, Minnesota B. Studies, Oct. I904.

Friedenfeldt, Bibliotheca B., No. 61, I904.

Friederick, B. Centralblatt, xcix., I905.

Fries, N. Acta . . Upsal., I905.

Fritsch, P. Roy. Soc., vol. lxxix., p. 203.

Früh and Schroter, Die Moore der Scliceiz, I904.

Gadow, Through Southern Mexico, I908.

Gaidukov, Ber. d. dent. B. Ges., xxi., I903, p. 484.

Garjeanne, Flora, I891.

Gautier, La Géographie, I905. 


\section{Bibliography}

Geographical Journal, March I9oo.

Gibson, New Phytologist, iii., I904, p. I84.

Giltay, Jahr.f. w. Bot., xliii., I906.

Goebel, B. Centralblatt, I904.

Goebel (see Groom).

Goeze, Just (2), I904, p. 902.

Golenkin, Jahrb. f. w. Bot., I902.

Gordon, T. \& P. of B. S., Edinburgh, vol. xxiii., pt. iv.

Graebner, Die Heide Norddeutschland (I'eg. d. Erde), vol. v.

Grafe, Just (r), I905, p. I79.

Green, P. Roy. Soc., lxxiii., I904.

Groom, $P$. and T. Roy. Soc., vol. cc.

Guppy, Observations of a Naturalist in the Pacific, I9o6.

Haberlandt, Ber. $d$. deut. B. Ges., xxii., I904.

Handlirsch, Verh. z. b. Ges., Wien, I904, p. I I 4 .

Hansgirg, Phyllobiologie, I903.

Harden, P. Roy. Soc., vol. lxxvii., p. 424.

Hartig, B. Centralblatt, lxxiv., 1898, p. 295.

Hartz, B. Centralblatt, xcvi., p. 398.

Harwood, New Creations in Plant Life, 1907.

Haupt, Flora, I902, p. I.

Heckel, Bull. S. B. d. l., France, I907, p. I37.

Heering, Just (3), I905.

Heinricher, (I) B. Centralblatt, lxxxi., I897; (2) Jahr.f. $w$. Bot., I908.

Heller, Jahr. f. w. Bot., I904.

Hemsley, Jour. Linnean Soc., 1894.

Henry, Econ. P. R. Dublin Soc., I904.

Henslow, (I) Origin of Plant Structure; (2) Jour. Roy.

Hort. Soc., vol. xxvi., pt. iv., p. 668.

Hesselmann, B. Centralblatt, xcix., 1905.

Hildebrand (I) Ber. d. deut. B. Ges., xxi., I903; (2)

Verbreitungs. Pfanzen., 1873 .

Hill, New Phytologist, vii., I908.

Hiltner, Just, I904, p. 78.

Hoek, Beil. B. Centralblatt, xviii., I905.

Holmes, Pharmacentical Journal, I905, p. I4I.

Hooker, Flora Antarctica.

Humphries, Jour. Soc. Arts, Feb. 12, I909. 


\section{Bibliography}

Hunter. See Elliot, R. H.

Hurst, (I) Jourr. Roy. Hort. Soc., vol. xxvi., pt. iv., p. 688 ; (2) Conf. on Genetics, I906, p. II4.

Jacobitz, C. B. f. Bakteriology, Bd. vii., Jena, I9or.

Jeffrey, Amnals B., I906.

Johansen, Conference on Genetics, 1906.

Jones, Jourr. Roj'. Hort. Soc., I906, pp. 348, 357.

Jönsson, B. Centralblatt, vol. xcvi., p. 29.

Just, Botanische Jahresberichte (annual).

Karsten, Just (I), I905, p. 7I2.

Katic, Just (3), 1905.

Kegel, Just (3), I905, p. I4I.

Keller, Mitheil. d. n. Ges., Winterthur, I704.

Kerekgyarto, Just. (2), I 904, p. I I77.

Kew Bulletin, I905.

Kienitz Gerloff, Bakterien 1 . Hefe, I904.

Kirchner, Loew, and Schroter, Lebensgeschichte d. Blïtenpflanzen Middel Europes, Stuttgart, I908.

Klebs, Jahrb. f. w. Bot., xliii., 1906.

Klöcker, Gärungsorganismen, I900.

Kniep, Jahr. f. w. Bot., I 906.

Knight. See Henslow (I), p. I20.

Knuth, Engler's B. J., I903.

Koernicke, Ber. d. deut. B. Ges., I 904 and 1905.

Koford, Bull. Illinois St. Lab. N. H., Nov. I903.

Kolkwitz, B. Centralblatt, Bd. 1xx., I 896 .

Koning and Heinsius, B. Centralblatt, xcriii., I904.

Konradi, C. B. f. Bakt., Bd. xxxvi.

Korschinsky, Flora, vol. 1xxxix., I90I.

Kosaroff, Just (I), I905, p. I58.

Krasan, (I) Engler's B. J., I899, I900 ; (2) see Henslow

(I), p. I20.

Kraus, Just (2), I906, p. 286.

Kunze, Jahr. f. w. Bot., I905, p. 357.

Kupper, Jahrb. f. w. Bot., I906.

Kuster, Ber. d. deut. B. Ges., xxiii., I905.

La Floresta, Just (2), I905, p. 59.

Lamplugh, British Association Reports, 1906.

Laurent, Just (2), I905. 


\section{Bibliography}

Lawes, Gilbert, and Pugh. See Rothannstedt Reports.

Leavitt, Plant-world, I905, p. 239.

Ledinghem, $P$. Roy. Soc., vol. lxxx.

Lesage, Rev. Gen. d. B., I89o.

Lewis, T. Roy. Soc., Edinburgh, vols. xli. and xlv.; Scot. Geog. Mag., May I906; Geog. Jour., March I904; Science Progress, No. 6, I907.

Lidforss, Ber. d. deut. B. Ges., xxiii., I 905.

Liebscher and Van Seelhorst, B. Centralblatt, Bd. 1xxiv., I 898, p. 248.

Lilienfeldt, Ber. d. dent. B. Ges., xxiii., I905.

Lindau, (I), Sitz . . . Preuss. Akad. IViss, xxxv., I904;

(2) Jour. Roy. Hort. Soc., Dec. Igor, p. $5^{1} 3$.

Linsbauer, Sitz. Akad. Wien, cxiv., r905.

Loew, Verh. Brandenburg, xlvii., I905.

Lohmann, B. Centralblatt, xcviii., I905.

Lothelier. See Henslow (I).

Lowenherz, Zeit. f. P. Krankheit, I905, p. 137.

Lowenstein, Ber. d. deut. B. Ges., xxi., I903, p. 3 I 7.

Lyons, Geog. Jour., Nov. I908.

McCallum, B. Gazette, vol. xxxiv.

Macfadyen and Rowland, Nero Plyytologist, i., I8, p. I74.

Macfarlane, Conf. on Genetics (I906), p. I55.

Macnaghten-Jones, Pharmacentical Jour., Nov. 2 I, I908.

Maeterlinck, L'Intelligence des Flcurs, Paris, I907.

Magnin, Annı. S. B., Lyons, I902.

Maheu et Combes, B. s. b. de la France, 1907.

Malinvaud, Conf. on Genetics (Roy. Hort. Soc.), I 906, p. I 82.

Marloth, T. S. African Phil. Soc., xv., I904.

Masayasu, Just (2), I904, p. 432.

Massart, (I) Just (2), I904, p. 7 I8 ; (2) B. Centralblatt, lxxv., I 898.

Massee, Jour. Limnean Soc., Nos. I83, I84.

Massee and Salmon, Annals B., I90I, p. 317.

Masters, Jour. Linnean Soc., vol. xxvii., Nos. I83, I84, I896, p. 226.

Maxwell, Memories of the Months, vol. iv.

Meyer, Com. Rend., t. cxxxviii., I904, p. IoI.

Mez, Engler's B. J., xxxiv., I905. 


\section{Bibliography}

Miehe, Just (3), I903, I904, p. 684.

Mittmann. See Henslow (I).

Moebius, Ber. d deut. B. Ges., xxi., I903.

Molisch, (I) Lenchtenden Pflanzen, Jena, I904; (2) Ber.d deut. B. Ges., xxiii., I905.

Molliard, Com. Rend., Oct. 7, I901 ; Jour. Roy. Hort. Soc., vol. xxvii.

Montemartini, Atti. d. b. ist., Pavia, I904.

Moore, Jour. Limnean Soc., No. 237.

Morris, Conf. on Genetics (Roy. Hort. Soc.), r9o6, p. 31

Moss, Geog. Jour., May I904.

Muir and Ritchie, Mannal of Bacteriology', 1908.

Murray, G., Introd. Brit. Seaweeds.

Murray, J., Geog. Jour., Jan. I908.

Nakamura, B. C. Agric., Tokio, I904.

Neger, Jahrb. f. w. Bot., I902, p. 245.

Nemec, Regeneration, I905.

Nestler, Sitz . . Akad. w., Wien, cxiii., I904.

Nicotra, Malpighica, xix., I905.

Oliver, (I) New Plytologist, iii., I904; (2) Annals B., vol. ii., No. 5 .

Otto and Neumann, C. B. f. Bakteriol. Abtheil., xiii., I904.

Parkin, Annals B., 1904, p. 223

Parkin and Pearson, Jour. Limnean Soc., Nos. 238, 246, I903.

Pax, Grundz. Pf. Terbreit. Karpathen, I908.

Pearson, $P$. and T. Roy. Soc., vol. cxcviii., p. 265.

Percival, Agricultural Botany.

Pfeffer, Stickstoffsammuclnd. Bakt., Berlin, I904.

Pierce, Amnals B., I9o6.

Pitsch, Jour. Roy. Hort. Soc., May I904.

Plowman, B. Centralblatt, xcix., I905.

Pollacci, (I) B. Centralblatt, xcix., I905; (2) Atti . . Univ'

Pavia, vii., viii., I902, I904.

Potonié, Just, r 905.

Pringsheim, Jahrb. f. w. Bot., I9o6.

Prout and Hood, Gard. Chronicle, No. 866, I903.

Radde, Jour. Linnean Soc., No. I94, I89I; also Engler's Veg. d. Erde (Kaukasus). 


\section{Bibliography}

Raunkiaer, B. Centralblatt, xcviii., I905.

Reiche, Engler's Veg. d. Erde; Chilienflora.

Reid, Originls of British Flora.

Reinke, (I) Ber. d. deut. B. Ges., I903, I904; (2) B. Cenltralblatt, vol. xciii., p. 561.

Reinsch, Jahrb. f. wiss. Bot., I904.

Renwick, T. N. H. S., Glasgow, vols. vi. and vii.

Resvoll, Just (2), I904, p. I I24.

Richards, Amals B., I896, p. 33I.

Ridley, (I) New Phytologist, iii., I904; (2) Jour. Linnean Soc., vol. xxxii., No. I95; (3) Annals B., xix., I905.

Rikli, I'iertelj. d. naturw. Ges., Zurich, 1904, p. I28.

Russell, P. Roy. Soc., vols. 1xxviii. and 1xxx., pp. 376, 385 . Salmon, (I) Conf. on Genetics (Roy. Hort. Soc.), I906; p. 382 ; (2) Annals B., I905.

Sammet, Jahr.f. w. Bot., xli., I905, p. 6I I.

Sargent, Manlal Trees of North America, 1905.

Saunders, Conf. on Genctics (Roy. Hort. Soc.), I 9o6, p. I43.

Schimper, Pflanzen Geographie, I898.

Schneider, Torreya, vol. v., I905.

Schrammen, Terh. . . . ver. Preuss. Rhcin., 1x., I903.

Schulz, (I) Ber. d. deut. B. Ges., wxi., I903; (2) also xxii., I904; Engler's B. J., I903; Beill. B. Centralblatt, xvii., I904.

Schunck, P. Roy. Soc., vol. lxxii., I903.

Scott, (I) Annals B., I904 ; (2) IVilde Lecture, Manchester, I904; (3) Annals B., I906, p. 229.

Scott Elliot, (I) First Conirse in Practical Botany, I906 ; (2) B. Soc., Edinburgh, vol. xxiii. ; (3) Naturalist in Mid Africa ; (4) Romance Plant Life.

Semon, Biolog. C. B., xxv., I905.

Sernander, Just (3), I906, p. 284.

Seward, Darwin Wallace Celeb., I9o8.

Sewell, B. Soc., Edinburgh, vol, xvii., Pt. iii., I889.

Shaler. See Früh and Schroter.

Shibata, (I) Farmer, Sammet ; (2) B. Mag., Tokio, I903. Shull, (I) B. Gazette, vol. xxxviii.; (2) American Naturalist, vol. xxxvi, I902.

Sigmund, C. B. Bakteriol (2), I905. 


\section{Bibliography}

Singer, Agricultural History of Dumfries.

Smith, R., (I) P. Perthshire Soc. Nat. Hist., I898 ; (2) Botanical Survey of Scotland, North Perthshire, Edinburgh.

Smith, R. and W. G., Scot. Geog. Mag., I904 and 1905.

Smith, W. G., Scot. Geog. Mag., Nov. I902 ; Botanical Survey of Forfar and Fife.

Smith, W. G. and Lewis, Geog. Jour., April I903.

Smith, W. G. and Rankin, Geog. Jour., August I903.

Somerville, T. Roy. Scot. Arbor. Soc., Jan. I908.

Sorauer, (I) see Jour. Roy. Hort. Soc., April I902, p. 900 ;

(2), Zeits. f. Pf. Krankh., Igor.

Spalding, Bull. Torrey Club, vol. xxxii.

Spruce, Notes of a Botanist on the River Amazon, 1908.

Stahl, Festschrift z. 7oth Gebürtstag v. E. Hïckel, Jena, I904.

Stahlecker, Just (I), I905, p. 644 .

Stant, Die Geschichte d. Gennis Cinnamomnum.

Stebler and Schroter, The Best Forage Plants.

Steinbrinck and Schinz, Flora, I908.

Stone, Hatcl Exp. St., Massa. Bull., xci., I903.

Stopes and Watson, $P$. and T. Roy. Soc. B., cc., p. 167 .

Suess, Antliss der Erde.

Svendsen, Just (2), I906, p. 386.

Tansley, (I) New Phytologist, vii., Nos. 4 and 5 ; (2) ditto,

iv., 1905 .

Terras, P. Scot. Micr. Soc., vol. iv.

Thomas, (I) Annals B., I902, p. I67 ; (2) I'erh. Brandenburg, xcv., I903.

Thomson, J. Arthur, Heredity, 1907.

Thorold, Jour. Linnean Soc., No. 206, I894.

Thwaite, Jour. Roy. Hort. Soc., June 1908.

Timiriaseff, P. Roy'. Soc., vol. lxxii., I903, I904, p. 424.

Tischler, Flora, xciv., I905.

Tommasina, Com. Rend., vii., Nov. I904.

Treub, Warming (I), Schimper (I).

Tschermak, Ber. d. dcut. b. Ges., xxii., r904, p. 445.

Tschirch, Flora, xciv., I905.

Turnbull, P. S. b. Edinburgh, vol. xxi., pt. ii.

Ule, Engler's B. J., Bd. xl., Heft iv. 


\section{Bibliography}

Ursprung, Bibliotheca B., I903.

Usher and Priestley, P. Roy. Soc., vol. 1xxriii., B., p. 3 I8.

Valentiner. See Molisch (2).

Vaughan-Cornish, Geog. Jour., Feb. I909.

Vierhapper, Beil. B. Centralblatt, xix. (2), 1906.

Von Faber, Beilı. B. Centralblatt, Bd. xxiii., p. 27.

Warming, (I) Ecological Plant Geograpliy, 1896 ; (2) Fam.

\section{Podostemac.}

Watterson, B. Centralblatt, xcvi., p. 270.

Webb \& Berthelot, H. Nat. d. i. Canaries.

Webber, U. S. Dept. Agr. Bull., xviii., 1897.

Weindorfer, Vict. Naturalist, B. Centralblatt, vol. xcvi. Weiss, (I) B. L. Owens College, I904; (2) N. Phytolog. vii., No. I.

Weisse, Jahr.f. w. Bot., vol. xxx., I897.

Weismann, The Evolution Theory.

Weldon, Biometrika, vol. i. pt. iii ; Inlieritance in Animals and Plants.

Went, Just (2), 1904, p. 626.

Wesenburg, Lund, and Larsen, B. Centralblatt, xcri., p. 405.

West, (I) Geog. Jour., I908 ; (2) British Desmidiaceae.

Wettstein, Von, (I) Handbuch d. systcm. Bot. ; (2) Just (2), 1904, p. 697.

White, (I) Flora of Perthshire; (2) T. B. S., Edinburgh, vol, xxii., pt. vii.

Wiesner, Sitz. k. k. Akad., Wien, cxv., I906.

Wildt, Just (2), I906, p. 460.

Wilks, Conf. on Genetics (Roy. Hort. Soc.), I9o6, p. 85 .

Willkomm, Engler's Veg. d. Ered; Iberisch. Halbinsel, 1896. Winkler, (I) A.J. B. Buitenzorg, xx., I905; (2) B. d. deut. b. Ges., xxi., 1903, p. 104.

Worsdell, Annals B., I904, p. 57 ; New Phytolog., ii., I903. Wulff, B. Beobacht. a. Spitzbergen Lund, I902.

Wylie, Contrib. Hull Bot. Laboratory, r904.

Yapp, Annals B., I902.

Yule, Biometrika, vol. i., pt. iii., p. 307.

Zacharias, Forsch. Biol. Stat. Plön Theil, x., I903.

Zalenski, B. Centralblatt, I904.

Zavitz, Conference on Genetics, I906 (Roy. Hort. Soc.). 


\section{INDEX}

ABSORPTION, 329

Abysmal flora, I 33

Acacia, 177, I78, 196, 207, 307

Acquired characters, I 20, 206, 295

Aeroplane fruits, 278

Afforestation, 77-78, 246

Agriculture, Irish, 251

" nomadic, 229

, Saxon, 25 I

, Spanish, 252, 309

Agropyron, 165

Air-spaces in plants, I 25

Albatross, $\mathrm{IO}_{2}$

Alcoholic fermentation, 55, I73

Algæ, 20, 22, 29, 31-41, I 37, I 39

Alinite, 45

Alluvials, I 33- I 36

Alpines, 96, I95

Alpine and Arctic, 89-98

Altitude, effect of, 276

Amazons, I 35

American trotters, 297

Animals, attacks of, I70, I75-179, 308-3I 4

Antarctic, 99-107

Ant-fungus, 209

Ant-gardens, 182, 209

Antherozoids, 149

Anthocyan, 187

Antitoxins, 55-58

Ants, 20I, 203, 205-210, 320

Aphis, 200

Apodya, I 39

Arable, 250-260

Araucaria, 24I, 242, 282

Araujia, I 50

Arbutus, 232

Arctic, 35, 22 I, 222

Argentine pampas, I 36, 264, 267

Armeria flats, I 58-162

Asparagus, 3 I I

Astragalus, 3 I I

Atavism, 305

Australian flora, 314
Azorella, I0o

Azotobacter, 43

BACTERIA, 45-62, I33, I 39, I49, I93, I94

Balearic flora, 3 II

Bamboo, 257, 261

Banana, 274

Barberry stamens, 148

Baudouin, 52

Bee-orchid, I 22

Beech invasion, 232, 239

Beech, Antarctic, 99, 100, 106

Biometry, 327

Birch flora, 222, 23 I

Birds, I 29, 202, 278

Blackman and Matthaei, I 53

Blaeberry, 90

Bocconia, 187

Bogslides, 74

Bohemian forest, 243

Botanical Survey, 224

Bougainvillea, I 14

Brachyphyllum, I 55

Bracken, 87, I 85

Breadfruit, 274.

British Columbia, 239, 240

British flora, 208-235

Brome mildew, 333

Bulrushes, I 30

Bunge, Dr., 43

Burbank, Luther, 288-290

Butterwort, 20I

Buttress roots, I 89

CActus, I 72-I 74, 290

Caesalpinia, 279

Calamariæ, 8I

Camargue, the, I6I

Campanula, 292

Cape Colony scrub, 314

Cardamine, 2 r 9

Carduus acaulis, I 77

Carpels, IO9 


\section{Index}

Caucasus, 94

Cavern mosses, I 8 I

Cecropia, 207

Cedars, 239

Cells, I 7

Ceropegia, I 56

Chalk lichens, 68

Chaparral, 3 I 4

Chara, I 32

Chemiotropy, I 49

Chilian sand-dunes, 166

,, scrub, 3 I 5

Chloroform, effect of, 330

Chlorophyll, 29

Chroolepus, $63-65$

Chusquiea, $26 \mathrm{I}$

Cinnamons, 235

Circumpolar flora, 97

Cladonia, 66

Clay, 18, 255

Claytonia, $23 \mathrm{I}$

Cleistogamy, II 3

Climbing plants, 23

Coal-measures, flora of, 33,80

Cocoanut, 274

Cockayne, Mr., 107

Cockspur thorn, I 75

Cold, effect of, 237,330

Colours of algæ, 3 I " of bacteria, 60

", of flowers, 96 , II I-I I 2

Combustion, spontaneous, 60

Commerson, I97

Composites, IO 3

Congo forest, 321

Conifers, 236-249

Continuity of protoplasm, I 40

Co-operation, II 4

Cordaites, 86

Cork, I 53, I 54

Cornish heath, 232

Cotton-disease, 288

Cotton-grass, 76

Cranberry culture, 77

Cucumber fungus, 335

Cycadofilices, 86

DARNEL fungus, I $8 \mathrm{I}$

Decapitated roots, 155

Deserts, 169-180, 182, 295, 297, 333

Desmids, 40

Deterioration, 293

Diatoms, 37, I 37

Discaria, 176
Dismal Swamp, 167

Dominance, 304

Double flowers, 299

Douglas fir, 239, 240

Dryas flora, 221, 23I

Dust, 67, I9I, I93

Dwarfing, 93-95

\section{EGYPT, I33, 170}

Electrical phenomena, 78, 211 , 216, 330

Elephant, 203

Elephant grass, 268, 317

Elodea, I 28, 213, 231

Entada, 279, 281

Environment, effect of, 123, 124, 181, 296, 297

Epiphytes, 23, 277

Equisetum, I30, 199

Erigerons, I2I

Eriocaulon, 233

Ether, 331

Ethereal oils, 3I3

Euphorbia, 174, 268

Evening flowers, II7

Fasciation, 300

Fechner, I4I

Fern-alliance, 79-88

Fern-growing point, I 55

Ferns, 287

Fires, effect of, 267, 268, 323

Fish, seed distribution by, 86

Floating islands, I 34

Floral clock, 118

Florida hyacinth, 126

Flower, 108-124

Flowering, times of, 256, 257

Fog of pastures, 72

Forest areas in Europe, 245

Forestry, altitude in, 29I

Forests and history, 195

Fortunate islands, $274^{-283}$

Frost, effect of, 5I, 92

Fruit-stalks, 190

Fungi, attack by, 245, 333, 335

" dispersion, of, 300

GALLS, $198-199$

Ganges, I 35

Gardiner, $\mathbf{r}_{40}$

Garigue, 307, 308

Geikie, 228

Geotropy, I23, I45, I46, 148

Geranium pratense, 123 


\section{Index}

German heath, 230

Germination, 272

Germ plasma, 156

Glyceria, I6 I

Goats, 308, 310

Grafts, 306

Grasses, 261-273

Grass heaths, 91

Groundsel, I86

Grouse disease, 5 I

Growth of lichens, 69

Guanaco, 198

Gum-cistus, 308, 310

Gum-tragacanth, 176

Gums, 177,312

\section{HABERLANDT, I 45}

Habit, 300

Hæmanthus, 146

Hairs, I74

Harpagophytum, 202

Hay meadows, 133

Hazel in Sweden, 226

Heat, effects of, 330

Heather moors, 75, 9I

Hevea, 208

Highland woods, 243

Holly, I 76

Honey, secretion of, I19, 151

Hooker, Dr., 99

Hot Springs, 33

Hybrids and hybridising, 287, 300-305

Hydrophobia, 57

Hygroscopic awns, 266

Hylæa, I 35

ICE, action of, $\mathrm{I}_{3} 8$

Ice Age, 218-221, 226-230, 233, 296

Individuality in plants, $152-156$

Insects, I 14-1 16, 123, I 24, 3 I9

Insectivorous plants, 201

Iris, 305

Iron bacteria, 6I

JUNGLE forests, 22

Juniper, 94

Jurassic, 87

Karoo, I7 I

Klebs, Dr., 122

Krakatoa, 19

LAGENOSTOMA, 86

Lamarck, 296
Lamium, I96, 254

Landes, 166

Land-forming plants, 129-136

Larch, 238, 240, 291, 292, 334

Lava-flows, 19, 277

Leaf-shape, 182

Leguminose, tubercles of, 45

Lens-like cells, I45

Lewis, Dr., 225, 227

Lichens, 20, 2 I, 89-99

Light, demand for, 244

Lilac, 216

Limestone flora, I I 3

Liquidambar, I 54

Litorella, I38

Lobelia, ${ }_{13} 8$

Lobelias, tree, 282

Locust fungus, 201

Loranthus, 196

Luzula, 97

Lythrum, 193

MACROCYSTIS, 35

Maeterlinck, 143

Maize, 262

Mangrove, 28o, 324-326

Manure, effect of, 178,198

Maqui, 307-310, 313

Marsh plants, I3I

Mechanical tissue, 190

Mendelism, 300-305

Mentha, 193, 287

Mesembryanthemum, 172

Mimicry, I 7 I, 196, I97, 205

Mimulus, 23I

Mirbelia, 199

Mites, I94

Mosquitoes, 322

Mosses, 24, 70 -78, 83, 99

Mutants, 298

Mycorhiza, 26, 82, 237, 335

NATURAL selection, I 24

Navigator plants, 278-28I

Nectaries, 208

Nemec, I 55

Nepenthes, I 50, 201

Nettles, 196

New Zealand and South America, 105

New Zealand sand-dunes, 47, 166

Nitragin, 47

Nitrobacterine, 47

Nitroculture, 47 


\section{Index}

Nitrogen, 43

Nostoc, 42

N-rays, 217

OAK forests, $223,225,229,23 \mathrm{I}, 250$

Oak-leaves, 182

Oats, 284,285

Oenothera Lamarckiana, 298

Old man's beard lichen, 66

Open floras, 21, 90, 93, 198

Ophrys, I 22

Opsonins, 57

Oranges, 287

Orchids, I 20, I 5 I, 277

Oscillatoria, 32

PACIFIC Islands, 230

Palm-leaves, 332

Pampas, I 36, 266, 267

Papyrus, I 34

Parasites, 4I, I47

Paspalum, I 35

Patanas of Ceylon, 185

Peas, Mendel on, 301

Peat, peat-moss, 70-78, 199, 225-227

Perfume industry, 312

Perie bush, 79

Permanent pasture, 269-273

Petals, I09

Petroleum, 82

Phagocytes, 56

Phalaris, I 37

Phosphorescence, 38, 59

Phragmites, I27, I30, 23 I

Physcia, 67

Pine, structure of, 237

Pinus maritimus, 167

Pitcher plant, I 50

Plankton, 36

Plant breeding, practical, 284-294

Podostemaceæ, I 83 theory of, 295-306

Poisonous plants, 199, 269, 3 I0

Poisons, effect of, I 50, 160, 329, 330

Pollen parent, effect of, 305

Pollination, I I6-I I 8, I 5 I, I 59

Polygonum amphibium, I27

Polypodium, 80, 208

Polytrichum, 70

Pondweed association, I 30

Potatoes, 286, 293

Potentillas, change in, 185

Prairies, 267

Preglacial plants, 218, 227, 228
Protoplasm, 17, I 23, I40-143, 147 I 49, 338

Psamma, 165-168

Pyrocystis, 38

RADIUM, 216

Rafflesia, 203

Rain, absorption of, 193

Rain-leaves, I 88

Ray-florets, I I I, I88

Reconquest of water, 125

Reed association, I $30,{ }^{6} 6_{3}$

Reid, Clement, 225, 227

Regeneration, I 55

Renanthera Lowii, I I 4

Renwick, Mr., 218, 2 I9

Resin, I 54, I 55, 332

Respiration, 33 I

Retama, I 7 I

Rhythm, 216

Rice, 262

Rock lichens, $6 \mathbf{j}-69$

Roman Britain, 229

Rontgen rays, 216

Roots, I 48

Rubber, 320

Rush association, I 32

Russell, Dr., 216

Rust fungi, 82

SAGINA, I 86

Sago, 274, 275

Salix, 93

Salt, I 57-I62, 329

Saltwort, I 58-I6I

Sand-dunes, I 64-167

Sand plants, I 64

Saprophytes, 335

Sargasso Sea, 36

Scent, I I 3

Scented Labiates, 308, 310

Scirpus associations, I $30, \mathrm{I}_{3}$

Scotch pine, forests of, $75,223,225-$ $230,238,239$

Scrub, 307-3 I 5

Seaside plants, I $57-168$

Season of flowering, I I 9

Seed, dispersal of, $\mathrm{IO}_{2}, \mathrm{I} 29,2 \mathrm{O} 2,2 \mathrm{O} 3$, 277

Selection, method of, 284

" by one seed, 287

Self-surgery, I 5.3, I 54, 332

Sempervivum, I 73

Sense life and sensitiveness, I23, I40-I 5 I 


\section{Index}

Sequoia, 241

Seven-leaf clover, I09, 287

Sheep, 309

Sheep-killing grasses, 26I

Shingle, 163

Silva Caledonia, 229

Sisyrhinchium, 234

Snares Island, I07

Snowdrop, 204

Soil, 48

Soldanella, I 85

Solomon's seal, 146

Somaliland, bush of, 312

Spanish flora, 219, 220, 255, 276, 308

Spartina association, 163

Sphagnum, 71, 72, 73, 91

Spiranthes, 233

Spraying of weeds, 258

Spruce, 29I -

Spruce-galls, 200

Spurs of petals, I19, I20

Statistical methods, 183

Statolith theory, I 47

Steppe grasses, 263, 266

Steppes, invasion of, 232

Stimulus of evil, $327-338$

Stocks, 303

Streptocarpus, 79

Struggle for existence, I 56

Succulents, I 72-173

Sudd of Nile, I33, I34

Sugars, I I9, 328

Summit floras, 89

Sundew, I 50

Sunshine, effects of, $187,233,240$

Sycamore, 29I, 29I, 292

TACITUS, 229

Tannin, 178

Tendrils, 148

Teneriffe, 275

Temperature, extremes of, 34

Tertiary flora, 218,276

Thais, 108

Thistles, 257

Thorns, 25, I 74-1 76

Tibetan plants, 94

Tillering of corn, 263

Tococa, 206
Torenia, IIO, I 55

Tracheid, I90

Trades dust, 37

Trapella, 129

Tree-ferns, 80

Tropical forests $316-326$

Tundra, 92

Tussocks, 27 I

ULE, Dr., $2 \circ 9$

Ultraviolet rays, 187

Urboden, 19

Vaccination, 58

Variation in flowers, 120

Variations, origin of, $182,183,327,328$

Vaucheria, I62

Venus' flytrap, 20 I

Victoria regia, 132

Viola, changes in, 184

Volvox, 45

Vossia, I 34

Walnut, Burbank's, 290

Water-lily zone, I 30 , I 32

Water plants, 125, 279

Water pollution, I 39

Wax of flowers, 120

Weathering of rocks, 68

Weeds, 95, 23I, 232, 254-258, 3 II

Weissmannism, 29I-298

Welwitschia, I 79

Werchojansk, 236

Wheat, 254, 284, 285, 288, 334

Willows, I 30 , I 32 , I 39

Wind, effect of, I 89

Wood, 24, 190, 245

Wood anemone, 26

Wood-floor, flora of, 244

Worms, 50, I97

Wounds, effect of, 331, 333, 334

Wulfenia, I 8 I

XAN'THOPHYLL, I I I

YIELD of crops, 259

Young leaves $v$. old ones, 152

ZosTerA association, I 58

Printed by Ballantyne, Hanson \&o Co.

Edinburgh \& London 



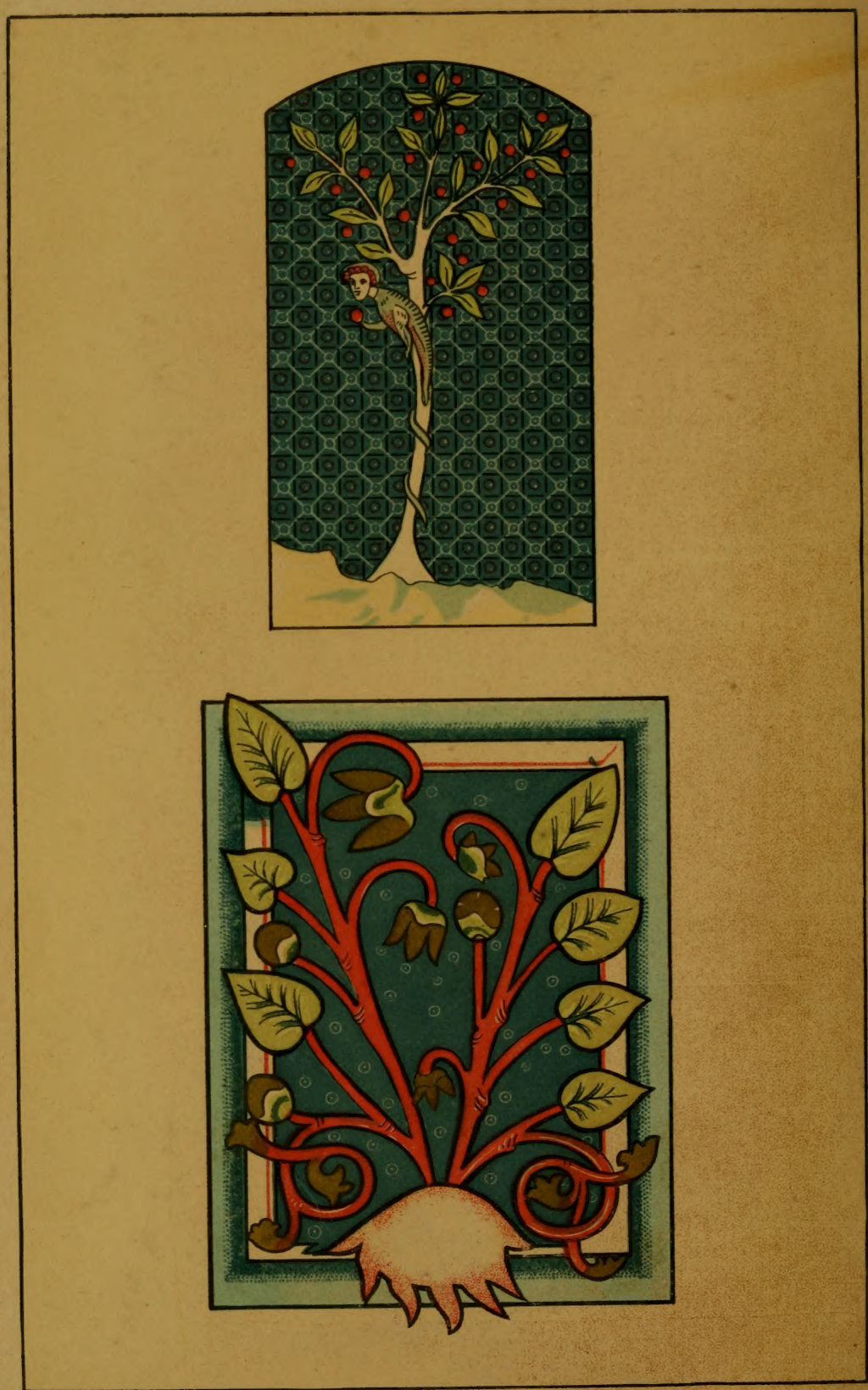

7. BOTANY OF 13 th CENTURY. (APPLE-TREE AND CYCLAMEN.) 
1.. Now York Botanical Garden Library gen

QK50 E39

Elliot George Fran/Botany of to-day, a

Elliot George Fran | || ||| ||| ||||||||||

|||||||||||||||||||||||||||||||||||||||||||||||||

- $\quad 35185001100906$ 
